Doktori értekezés Ph.D. fokozat elnyerésére

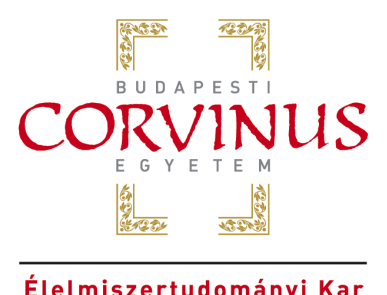

\title{
ÉLELMI NÖVÉNYEK POLIFENOLKÉSZLETÉNEK VIZSGÁLATA TÖMEGSPEKTROMETRIÁS MÓDSZEREKKEL
}

\section{SZILVÁSSY BLANKA}

Doktori (Ph.D.) értekezése

Készült:

Budapesti Corvinus Egyetem Alkalmazott Kémia Tanszék

Budapest, 2014 


\title{
A doktori iskola
}

megnevezése: Élelmiszertudományi Doktori Iskola

tudományága: Élelmiszertudományok

vezetője:

\author{
Dr. Felföldi József \\ Egyetemi tanár \\ Budapesti Corvinus Egyetem, \\ Élelmiszertudományi Kar, \\ Fizika-Automatika Tanszék
}

\begin{abstract}
Témavezető: $\quad$ Dr. Abrankó László
-2014. január 31-ig

Egyetemi docens

Budapesti Corvinus Egyetem,

Élelmiszertudományi Kar,

Alkalmazott Kémia Tanszék

2014. február 1-tól

Tudományos fömunkatárs

MS Proteomika Kutatócsoport

Szerves Kémiai Intézet

Természettudományi Kutatóközpont

Magyar Tudományos Akadémia
\end{abstract}

A doktori iskola- és a témavezető jóváhagyó aláírása:

A jelölt a Budapesti Corvinus Egyetem Doktori Szabályzatában előírt valamennyi feltételnek eleget tett, a múhelyvita során elhangzott észrevételeket és javaslatokat az értekezés átdolgozásakor figyelembe vette, ezért az értekezés védési eljárásra bocsátható.

Az iskolavezető jóváhagyása

A témavezető jóváhagyása 
A Budapesti Corvinus Egyetem Élettudományi Területi Doktori Tanácsának 2014. év június 03-i határozatában a nyilvános vita lefolytatására az alábbi bíráló Bizottságot jelölte ki:

BÍRÁLÓ BIZOTTSÁG:

Elnöke

Simonné Sarkadi Lívia, DSc

Tagjai

Biacs Péter, DSc

Woller Ágnes, PhD

Sárdi Éva, DSc

Halász Anna, DSc

Opponensek

Bartók Tibor, DSc

Balogh György Tibor, PhD

Titkár

Woller Ágnes, PhD 


\section{Tartalom}

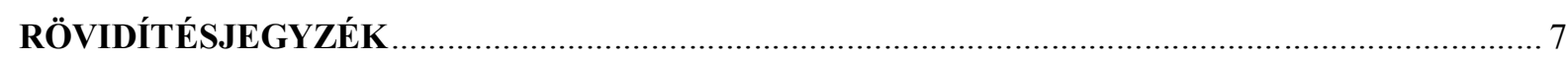

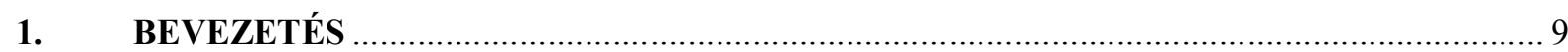

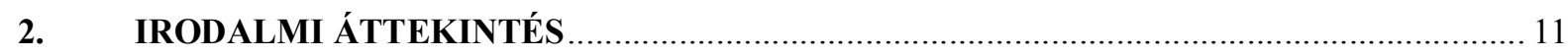

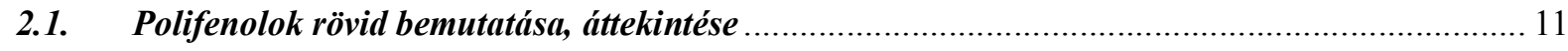

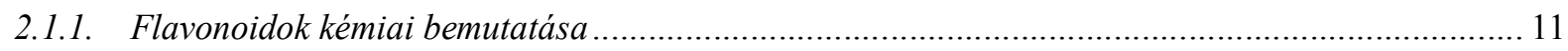

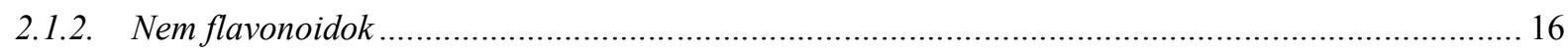

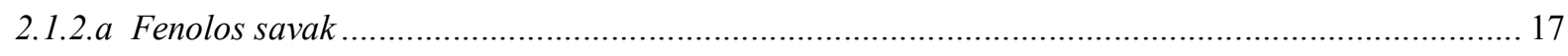

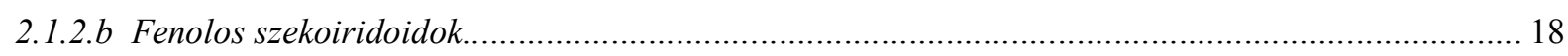

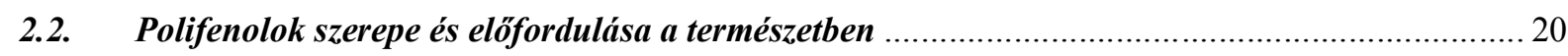

2.3. Vizsgált élelmi növények és a bennük található polifenolok bemutatása....................................2

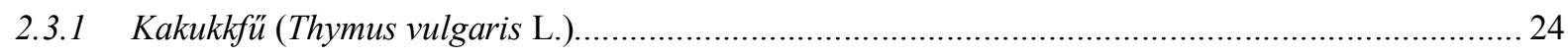

2.3.2 Szurokfü (Origanum vulgare L.)........................................................................................ 26

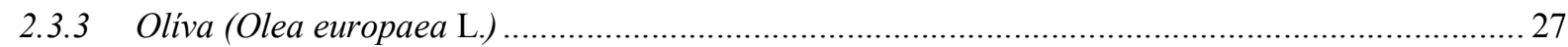

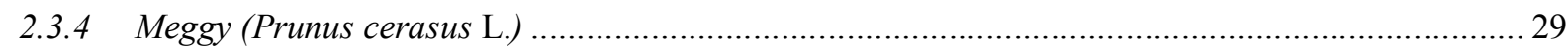

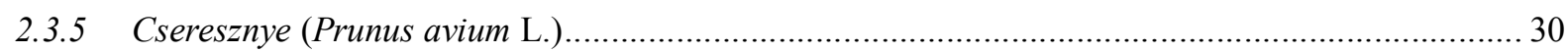

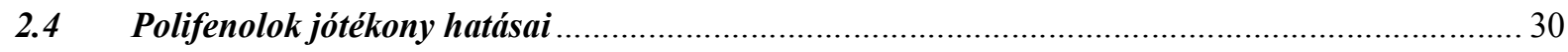

2.5. Mérési módszerek áttekintése az antioxidáns sajátságok meghatározásától a molekuláris

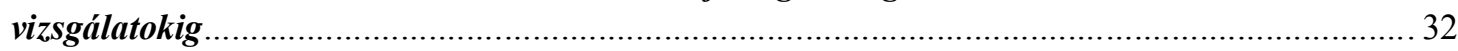

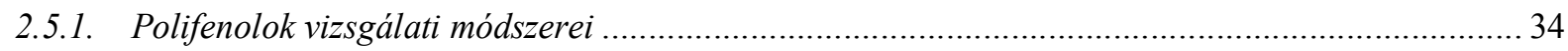

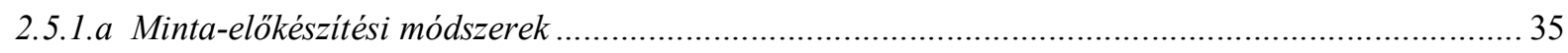

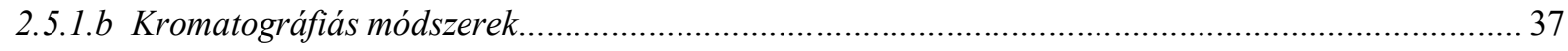

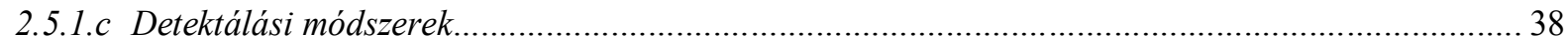

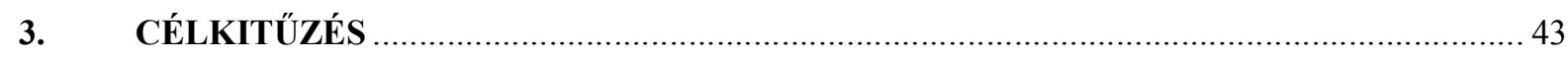

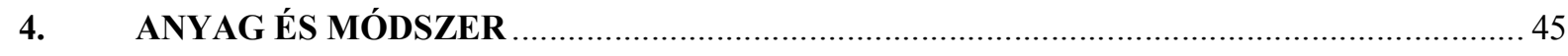

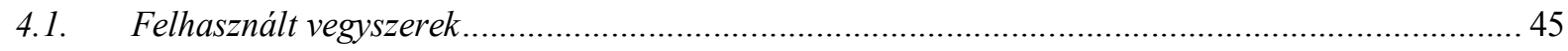

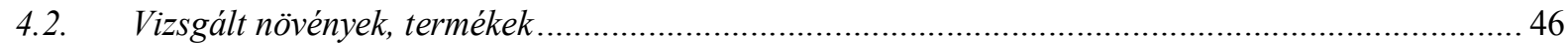

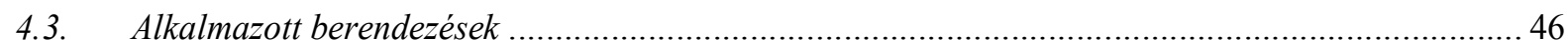

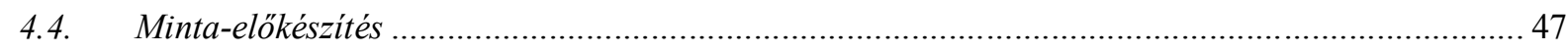

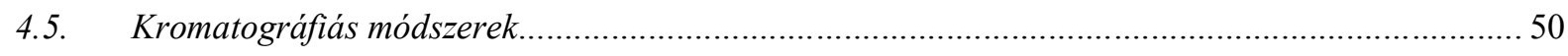

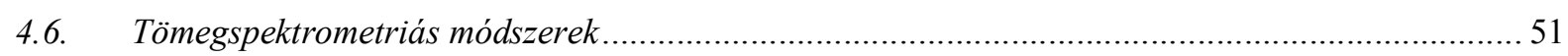

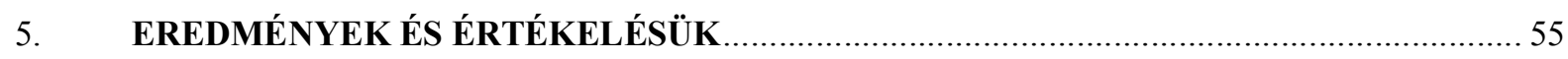

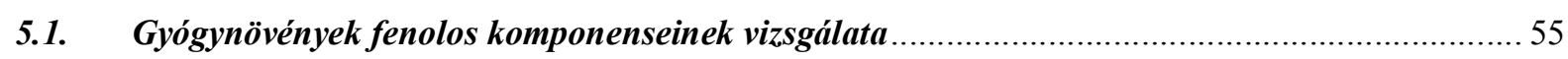

5.1.1. A gyógynövényekböl meghatározott fenolos savak bemutatása ……………………….............. 55

5.1.1.a. Kakukkfü (Thymus vulgaris L.) fenolos savainak vizsgálati eredményei .......................................55 
5.1.1.b. Szurokfü (Origanum vulgare L.) fenolos savainak vizsgálati eredményei ..... 61

5.1.2. A kakukkfüböl és szurokfüböl meghatározott flavonoidok bemutatása..... .65

5.2. Olívaolaj oleuropein-származékainak feltérképezö vizsgálata HPLC-ESI-TOFMS technikával. . 73

5.3. Izomer aglikonnal rendelkező flavonoid-glikokonjugátumok szelektív tömegspektrometriás vizsgálata. 88

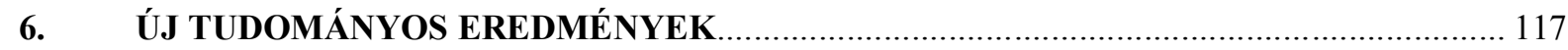

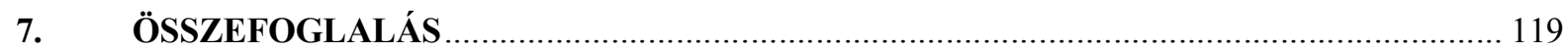

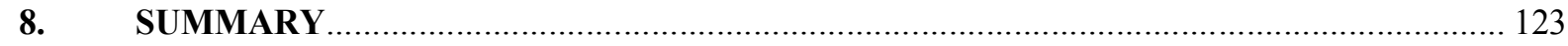

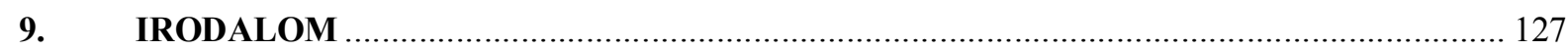

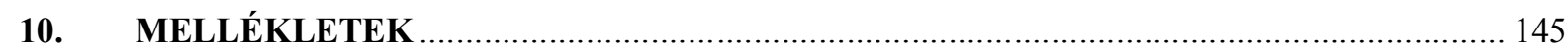

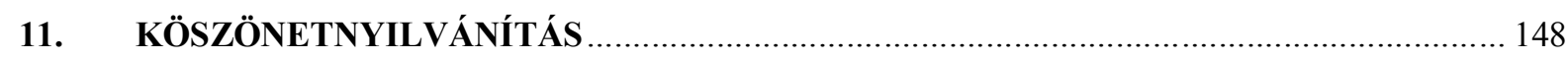




\section{RÖVIDÍTÉSJEGYZÉK}

\begin{tabular}{|c|c|c|}
\hline RÖVIDÍTÉS & ANGOL & MAGYAR \\
\hline ASE & Accelerated Solvent Extraction & Gyorsított oldószeres extrakció \\
\hline $\mathbf{C E}$ & Collision Energy & Ütközési energia \\
\hline CEP & Collision Cell Entrance Potential & Ütközési cella belépési potenciál \\
\hline CXP & Collision Cell Exit Potential & Ütközési cella kilépési potenciál \\
\hline $\mathbf{C y}$ & \multicolumn{2}{|c|}{ Cianidin } \\
\hline DP & Declustering Potetial & Klasztermentesítő feszültség \\
\hline Dp & \multicolumn{2}{|c|}{ Delfinidin } \\
\hline EIC & Extracted Ion Chromatogram & Kiemelt ionkromatogram \\
\hline EP & Entrance Potential & Belépési potenciál \\
\hline ESI & Elecrospray ionisation & Elektroporlasztásos ionizáció \\
\hline НCOOH & \multicolumn{2}{|c|}{ Hangyasav } \\
\hline Hex & \multicolumn{2}{|c|}{ Hexozid } \\
\hline Hex-a & \multicolumn{2}{|c|}{ Hexozilsav } \\
\hline HPLC & $\begin{array}{l}\text { High-Performance-Liquid- } \\
\text { Chromatography }\end{array}$ & $\begin{array}{l}\text { Nagyhatékonyságú } \\
\text { folyadékkromatográfia }\end{array}$ \\
\hline LLE & liquid-liquid extraction & Folyadék-folyadék extrakció \\
\hline МeOH & \multicolumn{2}{|c|}{ Metanol } \\
\hline MRM & Multiple Reaction Monitoring & Többszörös Termékion Figyelés \\
\hline MS & Mass Spectrometry & Tömegspektrometria \\
\hline MSPD & Matrix Solid-Phase Dispersion & Mátrix szilárd fázisú diszperzió \\
\hline Mv & \multicolumn{2}{|c|}{ Malvidin } \\
\hline $\mathrm{NaOH}$ & \multicolumn{2}{|c|}{ Nátrium-hidroxid } \\
\hline Pg & \multicolumn{2}{|c|}{ Pelargonidin } \\
\hline PLE & Pressurized Liquid Extraction & Nyomás alatti Folyadék Extrakció \\
\hline Pn & \multicolumn{2}{|c|}{ Peonidin } \\
\hline $\mathbf{P t}$ & \multicolumn{2}{|c|}{ Petunidin } \\
\hline PTFE & \multicolumn{2}{|c|}{ Politetrafluoretilén } \\
\hline Q-TOF & Quadrupole-Time-of-Flight & Kvadrupól-repülési idő \\
\hline SFE & Supercritical Fluid Extraction & Szuperkritikus folyadék extrakció \\
\hline SPE & Solid Phase Extraction & Szilárdfázisú extrakció \\
\hline SPME & Solid Phase Microextraction & Szilárdfázisú mikroextrakció \\
\hline SRM & Selected Reaction Monitoring & Kiválasztott Termékion Figyelés \\
\hline TFA & Trifluoro acetic acid & Trifluoroecetsav \\
\hline TIC & Total Ion Current/Chromatogram & Teljes Ionáram/Ionkromatogram \\
\hline TOF-MS & Time of Flight Mass Spectrometry & Repülési Idő Tömegspektrometria \\
\hline USDA & United States Department of Agriculture & $\begin{array}{l}\text { Amerikai Egyesült Államok } \\
\text { Mezőgazdasági Minisztériuma }\end{array}$ \\
\hline
\end{tabular}




\section{BEVEZETÉS}

Az epidemiológiai vizsgálatok meggyőző bizonyítékokkal támasztják alá, hogy a magas flavonoid bevitel számos, az egészségi állapotot pozitívan befolyásoló hatással bír, például csökkenti a szívkoszorú ér betegségek-, az asztma és krónikus tüdőbetegség kialakulását, antikarcinogén hatású, továbbá akár 65\%-kal csökkenti a szélütés kockázatát. A különbözö növényekkel, élelmiszerekkel elfogyasztott polifenolok egészségre gyakorolt jótékony hatását korábban főként a polifenolok antioxidáns hatásának tulajdonították [HALLIWELL, 2007].

Az utóbbi időben azonban szemléletváltás figyelhető meg, ugyanis a kutatók felfedezték, hogy ennél jóval összetettebb, molekuláris szintű mechanizmusok okozzák ezen egészségre gyakorolt jótékony tulajdonságokat [HOLST \& WILLIAMSON, 2008]. A szervezetre gyakorolt biológiai hatásokat a metabolizmus és a hatásmechanizmusok megfigyelése céljából aglikonokon tesztelték először [CROZIER et al., 2010; DEL RIO et al., 2010]. Mára már az is ismertté vált, hogy a növényekben a polifenolok föként származékok formájában találhatóak meg, melyek meghatározása sokféleségük miatt igen nehézkes [DE RIJKE et al., 2006]. Napjainkban már az is igazolást nyert, hogy az in vitro körülmények között biológiai hatást eredményező aglikonok konjugált változatai nem azonos mértékben hozzáférhetők az emberi emésztőrendszerben így a hatásosságuk is különböző [DAY et al., 2000; CROZIER et al., 2010; HOSODA et al., 2010]. Ennek fényében érthető, hogy olyan vizsgálati módszerek kellenek, amelyek nem csupán az aglikonokról, hanem a származékokról is információt nyújtanak [ABAD-GARCÍA et al., 2009; HARNLY et al., 2007; LIN \& HARNLY, 2007].

A doktori munkámban szereplő vizsgálatokat a fenti szemlélet alapján terveztem és végeztem el. Elsőként gyógynövények feltérképezése volt a cél fenolos savakra és flavonoidokra. Ezt követően spanyolországi tanulmányutam alkalmával olíva termékek oleuropein aglikonnal rendelkező származékainak hatásos kinyerésére törekedtem, illetve e származékok azonosítására nagy tömegpontosságú Q-TOF készüléken. Végül egy olyan módszerfejlesztés volt a cél, ahol azon szerkezeti izomériával rendelkező flavonoid komponensek is szelektíven megkülönböztethetőek, melyeket csupán a molekulák tömege alapján még egy nagy tömegpontosságú TOF készülék sem képes megkülönböztetni egymástól. 


\section{IRODALMI ÁTTEKINTÉS}

\subsection{Polifenolok rövid bemutatása, áttekintése}

A polifenolok kémiailag nagyon változatos molekulák, melyek a növények különböző fejlődési stádiumaiban másodlagos anyagcsere termékekként szintetizálódnak [MACHEIX \& FLEURIET, 1990].

Több mint 8000 fenolos szerkezetet fedeztek már fel, melyek széles körben elterjedtek a növényvilágban [STRACK, 1997].

A polifenolok nevezéktana nem egységes és nem is logikusan felépített. Egyes irodalmi források polifenolokként nevezik meg azokat a molekulákat is, amelyek az aromás gyürün csupán egy hidroxilcsoportot tartalmaznak (p-kumársav). A kémiai szemlélet szerint ezek monofenolnak, vagy egyszerü fenolnak tekinthetők. Az általános megnevezésre az angol „phenolics” szó a legmegfelelőbb, mely magyarul „fenolos komponensekként” fordítható. Ez magában foglalja azokat a komponenseket is ahol az aromás gyürün csak egy hidroxilcsoport található.

Hasonlóan kifejező lehet akár a „,(poli)fenolok” megnevezés is, de ez csak írásban fejezi ki a lényeget. A továbbiakban az egyszerüség kedvéért a hidroxilcsoportok számától függetlenül a polifenolok, illetve ennek szinonimájaként a fenolos komponensek kifejezést fogom használni.

A fenolos komponenseket - a legegyszerübb csoportosítási elv alapján - két főcsoportba sorolhatjuk: a flavonoidok illetve a nem-flavonoidok közé. A flavonoidok a fenolos komponensek legnagyobb csoportja, mely a központi heterociklikus gyürü oxidációs állapotától függően különböző osztályokká bontható tovább.

\subsubsection{Flavonoidok kémiai bemutatása}

A flavonoidok a kromon vegyületnek (vagy más néven benzo-gamma-pironnak) a származékai [WOLFENDER et al., 2010]. A növényekben aromás aminosavakból, nevezetesen fenilalaninból, tirozinból és malonátból képződnek [PIETTA, 2000]. Az alap flavonoid váz a flaván mag, mely 15 szénatomot tartalmaz három, $\mathrm{C}_{6}-\mathrm{C}_{3}-\mathrm{C}_{6}$ elosztású gyürüben, melyeket $\mathrm{A}, \mathrm{B}$ és $\mathrm{C}$ betükkel jelölnek (1. ábra). 


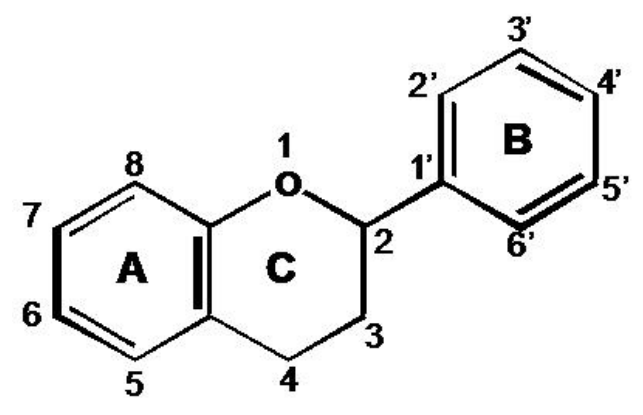

1. ábra: A flavonoid alapváz bemutatása

A természetben a flavonoidok különböző formákban lehetnek jelen. A váz lehet hidroxilezett, metilezett, illetve egyéb szubsztitúciós csoportok is kötődhetnek hozzá. A flavonoidok dimerekként is előfordulnak (ezek a biflavonoidok) melyek $\mathrm{C}-\mathrm{C}$ vagy $\mathrm{C}-\mathrm{O}$-C kötéssel is kapcsolódhatnak az aglikonok különbözö helyein. A legtöbbször azonban cukorszármazékként találhatóak $O$-glikozid vagy C-glikozid formában. A glikoziláció teszi a flavonoidokat polárisabbá, ami lehetőséget teremt a növények számára, hogy elraktározzák őket a sejtekben. $\mathrm{Az} O$ glikozidoknál az aglikon egy félacetál kötéssel kapcsolódik, míg a C-glikozidoknál a cukorhoz való kapcsolódás egy sav-rezisztens C-C kötéssel alakul ki. Természetes úton az $O$-glikozidoknál a leggyakoribb kötőhely az „A” gyürü 7-hidroxilcsoportnál van a flavon, flavanon és izoflavonok esetében, míg a flavonolok és flavanolok esetében a 3- és 7-es helyen, illetve az antocianoknál a 3as és 5-ös helyen. A C-glikozidok esetében csak az „A” gyürü C-6 illetve C-8-as helyén írtak le kapcsolódó cukor alegységeket. A flavonoid glikozidok legtöbbször glükózt tartalmaznak. Emellett galaktóz, ramnóz, xilóz és arabinóz szintén gyakran van jelen, de mannóz, fruktóz, glükuron- és galakturonsav is előfordul. Diszacharidok, mint a rutinóz és a neoheszperidóz, szintén gyakoriak. Nagyobb oligoszacharidok is kapcsolódhatnak, de ezek igen ritkák [ANDERSEN \& MARKHAM, 2006].

A különböző flavonoid osztályok az oxidáció fokában, illetve a „C” gyürü szubsztitúciós mintázatában térnek el. Az egyes komponensek az osztályokon belül az „A” és „B” gyürün elhelyezkedő szubsztituensek mintázatában különböznek, melyek leggyakrabban a „,B” gyürü 3', 4', 5' helyeit foglalják el. A flavonoidok csoportosítása a szubsztitúciós mintázat alapján egyszerünek tünhet, de a sokféleségük miatt ez sem egységes. Erre jó példa, hogy az 1993-ig 3 kiadásban megjelent „The Flavonoids, Advances in Research” című publikációban a flavanonok és a dihidroflavonolok, (vagy más néven flavanonolok) „minor flavonoidok”-ként szerepeltek, mert nagyon kevés ilyen fajta komponenst ismertek [HARBORNE, 1993]. Az utóbbi 15 évben azonban már közel ezerre tehető ezen flavonoid komponensek száma, így a „minor” kifejezés már nem helytálló [ANDERSEN \& MARKHAM, 2006]. Ebből is látszik, hogy az osztályozás, csoportosítás 
folyamatosan változik. A legutóbbi kutatási eredmények alapján a leggyakoribb flavonoidokat általában a következő csoportokba sorolják: flavonok, flavanonok, izoflavonok, flavonolok, flavanonolok, flavanolok és antocianidinek. Ezek általános szerkezeti képletét összefoglalva mutatja be a 2 . ábra.

\section{FLAVONOIDOK}

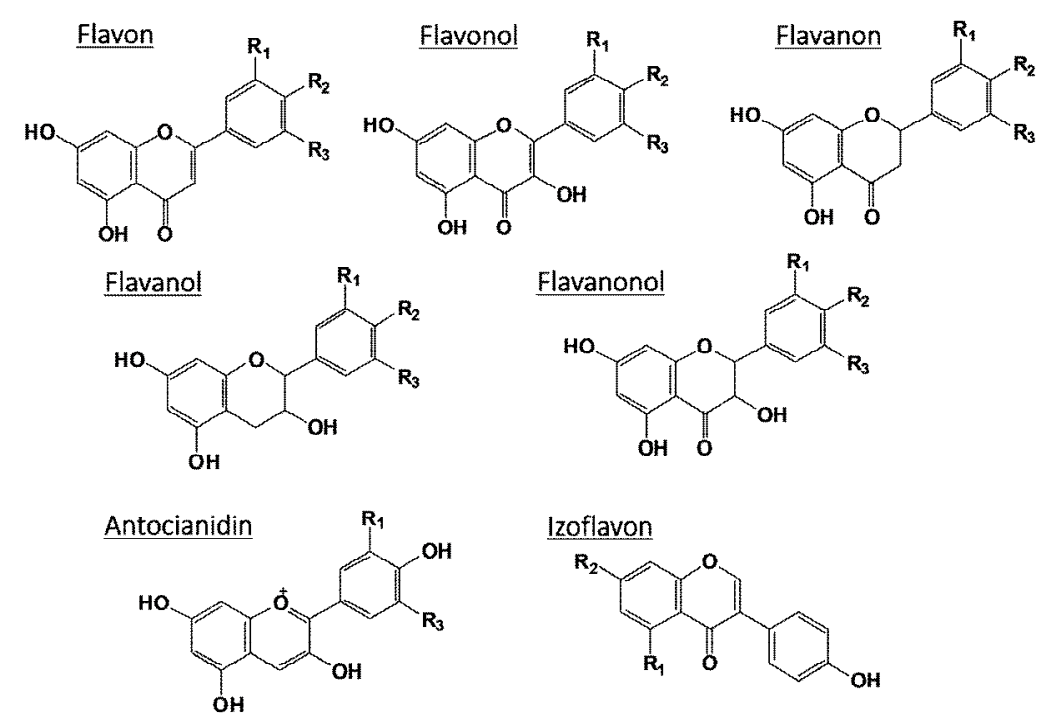

2. ábra: A flavonoidok föbb csoportjainak általános szerkezeti képlete

További flavonoid osztályok lehetnek a biflavonok, kalkonok, auronok és kumarinok. A hidrolizálható tanninokat, proantocianidineket (vagy flavan-3-ol oligomereket), kaffeátokat és lignánokat általában külön osztályba sorolják. A főbb alosztályokat kémiai jellegük és előfordulásuk szerint mutatom be röviden.

A flavanonok (más néven dihidro-flavonok) a flavonoid bioszintézis útjának első termékei és így a flavonoidok közvetlen prekurzorai. Jellemzőjük a C2-es királis centrum jelenléte és a „C” gyürü 2-es és 3-as szénatomja közötti kettős kötés hiánya. A legtöbb természetben előforduló flavanonnál a „C” gyürü a „B” gyürüvel a C2-es helyzetben kapcsolódik. A flavanon szerkezet nagyon reaktív, részt vesz hidroxilációban, glikozilációban és az $O$-metilezési reakciókban. Általában hidroxil-, vagy cukorszármazékként illetve $O$-metilezett származékként van jelen [WOLFENDER et al., 2010; ANDERSEN \& MARKHAM, 2006; DEL RIO et al., 2013].

A flavanonolok (más néven dihidro-flavonolok) egyik jellemzője, hogy a flavanonokhoz hasonlóan, a „C” gyürün a 2-es és 3-as C atom közötti kettős kötés hiányzik. A C-3-as kötőhely egyaránt hordozhat hidrogénatomot illetve hidroxilcsoportot, így egy további aszimmetriacentrumot alakíthat ki. Ezáltal négy sztereoizomer lehetséges minden egyes 
dihidroflavonol szerkezetre, $(2 \mathrm{R}, 3 \mathrm{R}),(2 \mathrm{R}, 3 \mathrm{~S}),(2 \mathrm{~S}, 3 \mathrm{R})$ és $(2 \mathrm{~S}, 3 \mathrm{~S})$. Mind a négy konfigurációra találtak példát a természetben előforduló dihidro-flavonolok között, de a (2R, 3R)-konfiguráció messze a leggyakoribb. A flavonoidokra jellemző általános származékképződési lehetőségek (5, 7, 3', 4', 5' helyek) mellett, a flavanonolok esetében C-3-as helyen lévő hidroxilcsoport lehet metilezett, glikozilált, vagy észterezett [ANDERSEN \& MARKHAM, 2006]. Ebbe a csoportba tartozik a taxifolin (vagy dihidro-kvercetin), az aromadedrin (vagy dihidro-kaempferol).

A flavonolok mint például a miricetin, a kvercetin, az izoramnetin és a kaempferol leggyakrabban $O$-glikozidokként vannak jelen. A konjugáció általában a C-gyürü 3-as pozíciójában jön létre, de a szénváz 5, 7, 4', 3' és 5' pozícióin is előfordulnak szubsztituensek. Bár az aglikonok száma korlátozott, számos flavonol származék létezik. Több mint kétszáz különböző cukorkonjugátum ismert csak a kaempferol esetében [DEL RIO et al., 2013].

A flavonok nagyon szoros szerkezeti kapcsolatban vannak a flavonolokkal. Bár a flavonoknak, mint a luteolinnak és az apigeninnek az „A” és „C” gyürükön vannak szubsztituensei, egy hidroxilcsoport hiányzik a C3-as pozícióról. A flavonok a szubsztituensek széles választékával rendelkezhet, beleértve a hidroxilezést, a metilezést, az $O$ - és $\mathrm{C}$-alkilezést, és a glikozilációt.

A legtöbb flavon 7-O-glikozidként van jelen [DEL RIO et al., 2013; CROZIER et al., 2009]. A flavonok legismertebb képviselői az apigenin és a luteolin.

Az izoflavonok esetében a „B”gyürü a 3-as helyett a C2-es pozicióban kötődik a „C” gyürühöz. Mivel szerkezetileg hasonlóságot mutatnak az emlösök ösztrogénjével, mely pszeudohormonális tulajdonságokkal ruházza fel az egyes izoflavonokat, gyakran fitoösztrogénnek is nevezik őket. Az alap szerkezeti tulajdonságokon kívül az ösztrogén hatást az „A” és „B” gyürükön lévő hidroxilcsoportok jelenléte magyarázza. Általában ösztrogén agonistaként sorolják be, de ezzel egyidejüleg ösztrogén antagonista is, mivel versenyez az ösztrogénnel a receptor helyekért. Ezek az izoflavonok általában négy formában találhatók meg: aglikon, 7-O-glükozid, 6”$O$-acetil-7-O-glükozid, valamint 6"-O-malonil-7-O-glükozid [COWARD et al., 1998].

A flavan-3-olok (vagy más néven flavanolok) a flavonoidok legösszetettebb alosztálya. Ide tartoznak az egyszerü (+)-katekin és az izomer (-)-epikatekin monomerek, illetve az oligomer és polimer proantocianidinek, melyek kondenzált tanninként is ismertek. A tanninok nagy hidroxiláltságú molekulák, melyek oldhatatlan komplexet képezhetnek szénhidrátokkal és fehérjékkel. Ez a felelős a tanninban gazdag élelmiszerek fanyar, összehúzó érzetéért, mivel kicsapja a nyál fehérjéit.

A flavan-3-olok két királis központja $(\mathrm{C} 2, \mathrm{C} 3)$ minden egyes „B” gyürü hidroxilációra 4 izomert alakít ki, melyek közül kettő, a (+)-katekin és (-)-epikatekin, a természetben elterjedt, míg a $(-)$-katekin és $(+)$-epikatekin sokkal ritkább. Az oligomer és polimer proantocianidineknek egy 
további királis központjuk van a C4-es pozícióban. A proantocianidinek két típusát különböztetjük meg (3. ábra), melyek közül a B-típusú proantocianidinek (+)-katekinből és (-)-epikatekinből alakulnak ki oxidatív csatolással a felső monomer C4-es és az alsó egység C6 vagy C8-as helyével oligomereket vagy polimereket képezve. Az A-típusú proantocianidinek esetében az egyik monomer „B” gyürüjének C2-es pozíciója és egy másik monomer „A” gyürüjének C7-es pozíciója között van még egy éter kötés. Proantocianidinek legfeljebb 50 egységig fordulnak elö polimerekként. Azokat a proantocianidineket, melyek kizárólag (epi)katekin egységeket tartalmaznak procianidineknek nevezik, melyek a növényekben található proantocianidinek leggyakoribb típusába tartoznak [ASHIHARA, 2006; CROZIER et al., 2009]. A proantocianidinek savas hidrolízis alatt színes antocianidineket alakítanak ki [SANTOS-BUELGA \& SCALBERT, 2000; RIBÉREAU-GAYON, 1972].

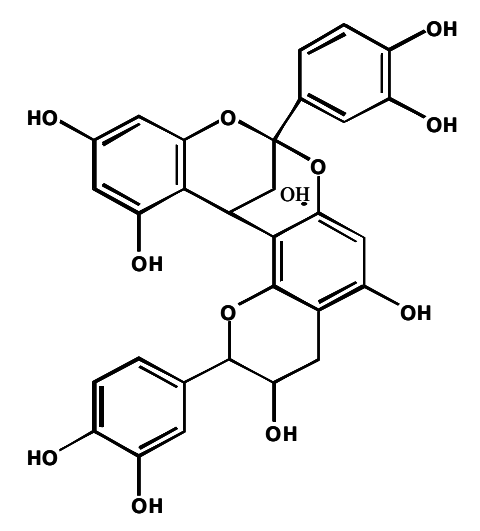

A- típusú proantocianidin dimer

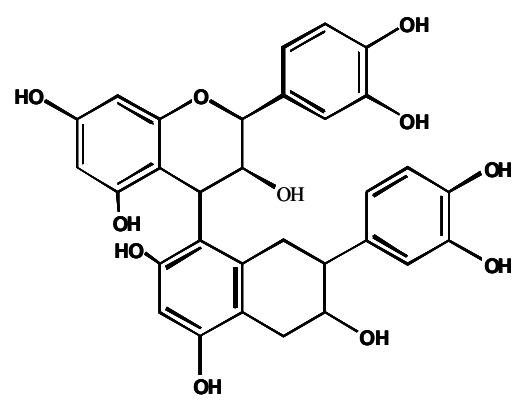

B- típusú proantocianidin dimer

3. ábra: A proantocianin dimerek két csoportjának bemutatása

Az antocianinok polihidroxi és polimetoxi származékai a 2-fenilbenzopirilium kationnak. A fö része az antocianinoknak az aglikon (flavilium kation), mely konjugált kettős kötéseket tartalmaz. Ezek felelősek az 500 nm hullámhossz közeli fény abszorpciójáért, ami miatt az emberi szem számára pirosnak látszik. Az antocianidinek (aglikonok) is a flavonoidokra jellemző $\mathrm{C}_{6}-\mathrm{C}_{3}-\mathrm{C}_{6}$ vázzal rendelkeznek [KONCZAK \& ZHANG, 2004]. Amikor az antocianidinek glikozidos formába kerülnek (azaz egy cukor részhez kapcsolódnak) akkor antocianinoknak (esetleg antociánoknak) nevezzük őket.

Az antocianinok sokkal stabilabbak és jobban oldódnak vízben mint az antocianidinek, mely a glikoziláltságuknak köszönhető [TIMBERLAKE \& BRIDLE, 1976]. A leggyakoribb cukrok az antocianinokban a glükóz, ramnóz, galaktóz, arabinóz és xilóz. A di- és triszacharidok esetében a leggyakrabban talált cukor a rutinóz, a szoforóz, a szambubióz és a glükorutinóz voltak [DE ANCOS et al., 1999; KÄHKÖNEN et al., 2003]. A cukor (glikán) rész leggyakrabban az „A” 
gyürü 3-hidroxilcsoportjához kapcsolódik illetve másodsorban az 5-hidroxilcsoportjához, vagy a 7hidroxilcsoporthoz [BROUILLARD, 1982]. Több cukoregységből álló glikán részek esetén a 3, 5 és 7 hidroxil-csoportokhoz egyaránt kapcsolódhatnak cukoregységek, melyek lehetnek lineáris vagy elágazó láncúak is [BRUNETON, 1995].

Az antocianinok acilezettek is lehetnek. A szerves savak, melyek az antocianin glikozidos csoportjához kapcsolódnak egy észter kötésen keresztül, általában vagy aromás fenolos savak vagy alifás dikarboxilsavak, vagy a kettő kombinációja. A savak leggyakrabban a monoszacharid 6-os kötőhelyéhez kapcsolódnak, de az antocianinok acil csoportjai a monoszacharidok 2-,3-,és 4-es kötőhelyeire kapcsolódnak [CABRITA, 1999]. A leggyakoribb antocianinhoz kötődő fenolos savak a hidroxi-fahéjsav származékai, mint a p-kumársav, ferulasav, kávésav, szinapinsav, illetve a hidroxi-benzoesavak, mint a galluszsav. A leggyakoribb alifás savak, melyek az antocianin molekulákban felfedezhetőek, a malonsav, ecetsav, almasav, borostyánkősav és oxálsav [BRUNETON, 1995; CABRITA, 1999; FRANCIS, 1989].

Az antocianinok ionos jellege lehetővé teszi a molekulaszerkezet változását az uralkodó pH értéktől függően, mely különböző színeket és színárnyalatokat eredményez [BROUILLARD, 1982; VON ELBE \& SCHWARTZ, 1996; DA COSTA et al., 1998; FLESCHHUT et al., 2006; HEREDIA et al., 1998; KENNEDY \& WATERHOUSE, 2000]. Savas $(\mathrm{pH}<3)$ körülmények között a piros flavilium ion a domináns [COOPER-DRIVER, 2001]. Az antocianinok stabilitására a „B” gyürühöz kapcsolódó szubsztituensek és a további hidroxi - és metoxicsoportok jelenléte is hatással van, mely csökkenti az aglikon stabilitását semleges közegben. Így a pelargonidin a legstabilabb antocianidin. Az aglikonokkal ellentétben, a monoglikozidok és főleg a diglikozid származékok stabilabbak semleges pH körülmények között. Ez azzal magyarázható, hogy a cukor molekulák megakadályozzák az instabil intermedierek fenolsav és aldehid komponensekre történő bomlását [FLESCHHUT et al., 2006].

\subsubsection{Nem flavonoidok}

A nem flavonoidok csoportja tartalmazza az egyszerü fenolokat, fenolos savakat, kumarinokat, xantonokat, kalkonokat, sztilbéneket, lignineket és lignánokat. A fenolos savak tovább oszthatóak benzoesav-származékokra, melyeknek egy $\mathrm{C}_{6}-\mathrm{C}_{1}$-es váz, illetve fahéjsav-származékokra, melyeknek egy $\mathrm{C}_{6}$ - $\mathrm{C}_{3}$-as váz az alapjuk [RIBÉREAU-GAYON, 1972]. A kumarinok fenolos sav származékok, melyek a hidroxi-fahéjsavak laktonjai. Természetes körülmények között megtalálhatók a növényekben szabad és származék formában is [SHAHIDI \& NACZK, 2003] . 
A xantonok egy $\mathrm{C}_{6}-\mathrm{C}_{1}-\mathrm{C}_{6}$ alapvázat tartalmaznak, a sztilbének pedig egy $\mathrm{C}_{6}-\mathrm{C}_{2}-\mathrm{C}_{6}$ vázból állnak különböző hidroxilezési mintákkal [ANDRÉS-LACUEVA et al., 2009]. A kalkonok egy $\mathrm{C}_{6}-\mathrm{C}_{3}-\mathrm{C}_{6}$ alapvázat tartalmaznak, melyből hiányzik egy heterociklikus „C” gyürü [ANDRÉS-LACUEVA et al., 2009], a ligninek a $\mathrm{C}_{6}-\mathrm{C}_{3}$ egység polimerjei [STAFFORD, 1988] míg a lignánok két fenilpropán egységből épülnek fel [MANACH et al., 2004]. A nem flavonoid típusú polifenolok legfontosabb csoportjainak általános szerkezeti képleteit foglalja össze a 4. ábra.

\section{NEM - FLAVONOIDOK}

Egyszerü fenol<smiles>[R6]c1cc(Br)ccc1O</smiles>

$\underline{\text { Sztilbén }}$

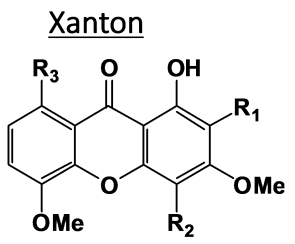

Kalkon
Kumarin<smiles>[R20]Oc1cc2ccc(=O)oc2cc1O</smiles>

Lignán<smiles>[R6]Oc1cc(O)cc(CCc2ccc(O)c(O)c2)c1</smiles>

Hidroxi-benzoesav

Hidroxi-fahéisav
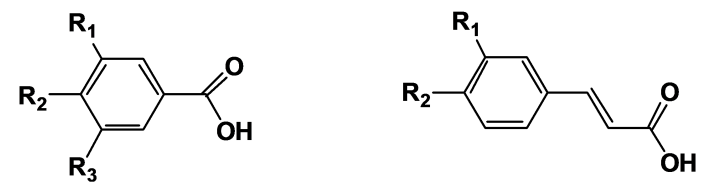

4. ábra: Nem flavonoid típusú polifenolok csoportositása és általános szerkezeti képlete

\subsection{2.a Fenolos savak}

A fenolos savak a nem flavonoid jellegü komponensek egyik legnagyobb csoportja [CROZIER et al., 2009]. A fenolos savak egyik csoportja a fahéjsav származékai (C6-C3), melyek széles körben elterjedtek, ritkábban szabad formában, nagyon gyakran pedig észterezett formában. A fahéjsavak fenilalaninból keletkeznek oly módon, hogy az ammónium csoport kiválik és a két szénatom egy kettős szénkötéssel összekapcsolódik [SHAHIDI \& NACZK, 2003]. A fenol gyürühöz való hidroxilcsoport kapcsolódásával alakulnak ki a hidroxi-fahéjsavak. A hidroxifahéjsavak közti különbség a fenol gyürün elhelyezkedő hidroxilcsoportok számában és pozíciójában van. A természetben szabad formában ritkán, de előfordulnak, azonban inkább az észterei jellemzőbbek. Belőlük szintetizálódnak a fenilpropanoidok melyek többek között a 
lignánok prekurzorai [SHAHIDI \& NACZK, 2003]. A legáltalánosabb hidroxi-fahéjsavak a pkumársav, kávésav, ferulasav és szinapinsav. Ezek konjugált formában jelennek meg például a borkősavval vagy a kínasavval. A klorogénsavak például, föként 3-O-, 4-O- és 5-Okaffeoilkínasavak tehát egy kávésav kínasavval képzett származékai [CROZIER et al., 2009].

A fenolos savak másik csoportja a benzoesav származékok, melyek éppúgy megtalálhatóak szabad formában, mint észterekkel vagy glikozidokkal együtt. A (mono)hidroxi-benzoesavak fenilpropanoidokból két szén vesztésével alakulnak ki [SHAHIDI \& NACZK, 2003]. Ezek jellegzetes képviselője például a szalicilsav, melynek acetilésztere az Aspirin hatóanyaga. A hidroxi-benzoesav hidroxilációja következtében jön létre a dihidroxi-benzoesav, vanilinsav, sziringinsav, galluszsav.

E két vegyületcsoport dekarboxileződésével keletkeznek az egyszerü fenolok.

Tradicionálisan a fenilpropanoidokat (azaz a fahéjsavak családjába tartozó komponenseket) és a benzoesav származékokat együttesen „fenolos savak”-nak nevezi az élelmiszertudománnyal foglalkozó irodalom. Azonban meg kell említeni, hogy ez a nómenklatúra nem feltétlenül helyes kémiai és szerkezeti szempontból [SHAHIDI \& NACZK, 2003].

\subsection{2.b Fenolos szekoiridoidok}

A szekoiridoidok alosztályokba való besorolása nem egységes és nem egyértelmü, mely kémiai tulajdonságából adódik. A szekoiridoidok az iridoidokból képződött molekulák, melyek monoterpének, egy metilciklopentán alapvázzal. A ciklopentán gyürü szétnyílása eredményezi a seco-iridoidokat (vagy magyarul szekoiridoidokat). Ezt az 5. ábra szemlélteti.

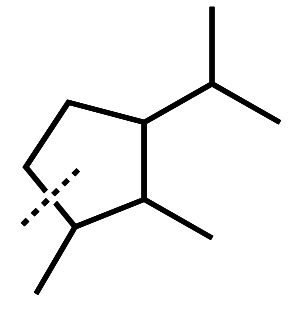

(a) iridoid alapváz

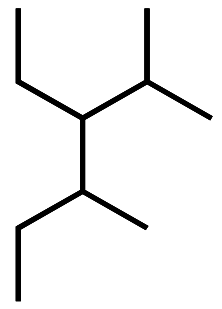

(b) szekoiridoid alapváz

5. ábra: Az iridoid és szekoiridoid alapváz bemutatása

A legtöbb iridoidot (a szekoiridoidokat is beleértve), növényekből izolálták, és ma már több mint 600 különböző szerkezeti formája ismert. Vannak aldehidek, alkoholok és laktonok, de a legnagyobb arányban glikozid formájában fordulnak elő. Szinte az összes szekoiridoid glikozidos 
formában létezik [RODRIGUEZ et al., 1998]. Az izolált szekoiridoid glikozidokat az oleozidoktól is származtatják.

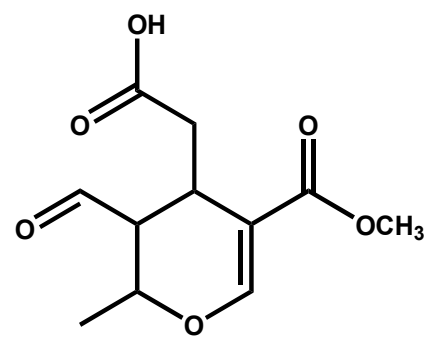

6. ábra: Az elenolsav szerkezeti képlete

A szekoiridoid glikozidok további származékokat képezhetnek például fenolos vagy terpén konjugátumokkal, illetve egyéb komponensekkel is [SHEN et al., 2000]. A szekoiridoidok szerkezetében elenolsav vagy annak származékai vannak jelen. Az elenolsav szerkezeti képlete a 6. ábrán látható. Ilyen elenolsav származékok az oleozidok is (7. ábra) .

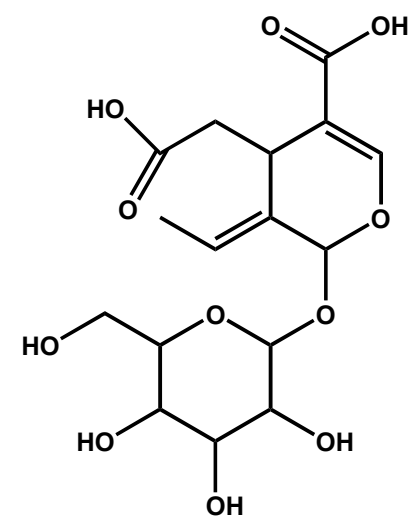

7. ábra: Az oleozid szerkezeti felépitése

Az oleozidok nem feltétlenül fenolos komponensek, de észterezödést követően tartalmazhatnak fenolos csoportot [SILVA et al., 2010]. Ez fordítva is igaz, tehát amennyiben a fenolos vegyületek molekulaszerkezetében az elenolsav vagy elenolsav származék jelen van, szekoiridoid komponensnek minősülnek [SERVILI \& MONTEDORO, 2002]. Ezért ezeket a komponenseket fenolos szekoiridoidoknak vagy szekoiridoid polifenoloknak nevezik. Ilyen fenolos szekoiridoid komponens például az oleuropein, a 10-hidroxi-oleuropein, ligsztrozid, a 10-hidroxi-ligsztrozid, stb. 


\subsection{Polifenolok szerepe és elöfordulása a természetben}

A polifenolok természetben betöltött szerepe két szempontból is jelentős. Egyrészt a polifenolok, mint másodlagos anyagcseretermékek különböző szerepeket játszanak a növényi ökológiában, például elősegítik a virág, gyümölcs és mag pigmentációját. Elősegítik a növény, a pollen kicsírázását, védenek a patogén mikroorganizmusoktól, a rágcsálók és más ragadozók ellen, illetve egyéb védő funkciókkal is rendelkeznek [DUTHIE et al., 2000; SCHIJLEN et al., 2004]. Ezek a komponensek felelősek a ragyogó kék, vörös színekért a levelekben, virágokban és a gyümölcsökben [BROUILLARD \& CHEMINAT, 1988]. Mutatós színüknek köszönhetően a flavonok, flavonolok és antocianidinek vizuális jelekként szolgálnak a beporzó rovarok számára. Katalizátorként müködnek a fotoszintézis világos szakaszában [PIETTA \& SIMONETTI, 1998] és stressz elleni védőanyagokként is szolgálnak a növényi sejtekben [PIETTA, 2000]. Továbbá, mivel kiváló UV elnyelő tulajdonságaik vannak, védik a növényt az UV sugárzástól és az UV által generált gyökös mechanizmusoktól [SHIRLEY, 1996]. Fanyarságuk miatt a katekinek és más flavanolok védelmi rendszert jelentenek a növényre ártalmas rovarok ellen [MAZZA, 1993].

Humán táplálkozástudományi szempontból az ember számára az előbbieknél fontosabb, hogy a polifenolok - a növényekben betöltött fiziológiai szerepükön túl - az emberi táplálkozásban is fontos szerepet játszanak, bár a flavonoidok az élelmiszerek nem tápanyag komponensei, vagyis nem jelentenek tápértéket az emberi szervezet számára. Valójában a flavonoidok táplálkozással bevitt szintje meglehetősen magas ha a $\mathrm{C}$ vitaminhoz (70 mg/nap), E vitaminhoz (7-10 mg/nap) vagy a karotinoidokhoz hasonlítjuk őket (7-10 mg/nap) [YAMASAKI et al., 1997]. A flavonoid bevitel 50 és $800 \mathrm{mg} /$ nap között változhat, a zöldség és gyümölcs-fogyasztástól és az olyan italok fogyasztásától függően, mint a vörösbor, tea, szüretlen sör [KUHNAU, 1976; LARSON, 1988]. Főként a vörösbor és a tea tartalmaz nagy mennységet (kb. $200 \mathrm{mg}$ egy pohár borban vagy egy csésze teában) az összes polifenolból. Így ezen italok nagymértékben felelősek a flavonoid bevitelért [PIETTA, 2000].

A polifenolok különböző osztályainak előfordulását a következőkben mutatom be, a kémiai bemutatásuk során alkalmazott csoportosítás szerint. Táplálkozásban betöltött szerepük okán, előfordulásuk áttekintésekor elsősorban az élelmiszerként is fogyasztható forrásokra helyeztem a hangsúlyt.

A flavonolok a legelterjedtebb flavonoidok a növényvilágban és az élelmiszerekben. Fő képviselőik a kvercetin és a kaempferol legnagyobb mennyiségben a zöldségekben és gyümölcsökben van jelen, föként ezek héjában, kivéve a hagymánál. Általában 15-30 mg/kg friss 
tömeg koncentrációban találhatók meg. A legnagyobb mennyiségben a hagymában, kelkáposztában, póréhagymában, brokkoliban, és a fekete áfonyában mutatták ki. A vörösbor és a tea szintén legfeljebb $45 \mathrm{mg}$ flavonol/liter koncentrációban tartalmazza ezeket a komponenseket, melyek általában glikozidos formában vannak jelen. A kapcsolódó cukorcsoport gyakran glükóz vagy ramnóz de más cukrok is előfordulhatnak, például: galaktóz, arabinóz, xilóz, glükuronsav [MANACH et al., 2004]. A gyümölcsök általában 5-10 különböző flavonol-glikozidot tartalmaznak. Ezek a flavonolok a növény külső szöveteiben halmozódnak fel (bör és levél) mert a bioszintézisüket a fény stimulálja. Markáns koncentráció különbségek figyelhetök meg ugyanazon a fán termett gyümölcsök között, sőt egyetlen darab gyümölcs különböző oldalán is attól függően, hogy hogyan kapta a napfényt [PRICE et al., 1995]. Hasonlóképpen a leveles zöldségekben, mint a fejes saláta és a káposzta, a glikozid koncentrációja tízszer nagyobb lehet a külső zöld levelekben, mint a belső világos színű levelekben [HERRMANN, 1976]. Ez a jelenség a cherry paradicsom esetében is igaz, mely magasabb flavonoid tartalmú, mint a hagyományos paradicsom, mert nagyobb arányú a bör része az egész gyümölcshöz képest [HERRMANN, 1976].

A flavonok sokkal ritkábbak a gyümölcsökben és zöldségekben, mint a flavonolok. A flavonok elsősorban a luteolin és apigenin glikozidokként fordulnak elő. Fontos élelmezési forrást jelent a petrezselyem és a zeller illetve az aromanövények, mint a rozmaring vagy a kakukkfü [PIETTA, 2000]. A gabonafélék, mint a köles, vagy a búza a flavonok C-glikozidjait tartalmazzák [KING, 1962; FENG et al., 1988; SARTELET et al., 1996]. A citrusfélék héja nagy mennyiségben tartalmaz polimetoxilált flavonokat: tangeretint, nobiletint és szinenszetint (akár 6,5 g / liter illóolaj is lehet a mandarin esetében) [SHAHIDI F, 1995].

A flavanonok az emberi táplálkozásban a paradicsomban és bizonyos aromanövényekben találhatók meg, mint amilyen a menta, de nagy koncentrációban csak a citrusfélékben vannak jelen [PIETTA, 2000]. A citrusfélék héjában a leggyakoribb flavanon-glikozid a heszperetin-7-Orutinozid (heszperidin). A flavanon-rutinozidok íztelenek, ezzel ellentétben, flavanonneoheszperidozid konjugátumok, például a heszperetin-7-O-neoheszperidozid (neoheszperidin) a keserü narancsban (Citrus aurantium L.) és a naringenin-7-O- neoheszperidozid (naringin) a grapefruit héjában (Citrus paradisi Macfad.) erősen keserü ízüek [ASHIHARA, 2006]. A narancslé 200-600 mg heszperidin / liter és 15-85 mg narirutin / liter flavanon koncentrációban tartalmazza ezen komponenseket, illetve egy pohár narancslé 40 - $140 \mathrm{mg}$ flavanon glikozidot tartalmazhat [TOMÁS-BARBERÁN \& CLIFFORD, 2000]. Mivel a citrusfélék szilárd részeinek, különösen az albedónak (a fehér szivacsos rész) és az elválasztó membránoknak, nagyon magas flavanon tartalma van, az egész gyümölcs akár 5-ször annyit tartalmazhat, mint egy pohár narancslé. 
A flavanonolok közül a taxifolin megtalálható a vörösfenyőben, illetve az açaí pálmában is, illetve kis mennyiségben a különböző fajtájú hagymákban taxifolin 3-glükozid, taxifolin 4'glükozid, és taxifolin 7- glükozid formában [SLIMESTAD et al., 2007]. Aglikonként mexikói oregánóból is kimutatták [LIN et al., 2007]. A dihidromiricetin-3-O-ramnozid [VITRAC et al., 2002] a borokban fordul elő, ugyanúgy, mint a dihidrokvercetin-3-O-ramnozid [LANDRAULT et al., 2002].

Az izoflavonokat gyakran nevezik fitoösztorgéneknek, mert szerkezetileg hasonlóak az ösztrogénekhez (hidroxilcsoportokkal rendelkeznek a 7-es és 4' helyzetben melyek konfigurációsan analóg helyzetűek az ösztradiol molekula hidroxilcsoportjaihoz képest) ezért megkötődhetnek az $\alpha$ és $\beta$ ösztrogén receptorokon. A leggyakrabban előforduló izoflavonok a genisztein, daidzein és a glicitein. Ezek az izoflavonok a növényekben általában háromféle konjugátumként találhatók meg: 7-O-glükozid, 6"-O-acetil-7-O-glükozid, valamint 6"-O-malonil-7-O-glükozid [COWARD et al., 1998]. A 6”-O-malonilglükozid származékok kellemetlen, keserü és fanyar ízüek [ASHIHARA, 2006; CROZIER et al., 2009]. Az izoflavonokat eddig szinte kizárólag hüvelyes növényekben írták le. Egy átfogó adatbázis szerint, melyet az Egyesült Államok Mezőgazdasági Minisztériuma adott ki a kiválasztott élelmiszerek izoflavon tartalmáról, a genisztein 5,6-276 mg/100 g tartományban van jelen a nyers érett szójában [BHAGWAT et al., 2008]. Más hüvelyesekben, a fekete babban, a zöldbabban és a csicseriborsóban is gyakran fordulnak elő. Például a Liggins és munkatársai által megjelent tanulmányban kiderült, hogy az arany tehénbab (Vigna radiata L.) kombináltan tartalmaz geniszteint és daidzeint 0,3-0,6 mg/100 g tartományban [DUTHIE et al., 2000; LIGGINS et al., 2000; SCHIJLEN et al., 2004]. A lucerna és lóhere hajtások és a napraforgómag is tartalmaz izoflavonokat [HERRMANN, 1976]. Ezek alapján elsősorban a szóját és ennek feldolgozott termékeit, másodsorban egyéb hüvelyeseket (babféléket) tekintik a fö izoflavon forrásnak az emberi táplálkozásban.

Ugyanakkor kutatócsoportunk eredményei azt mutatják, hogy bizonyos meggyfajták (Prunus cerasus L.) is nagy mennyiségben tartalmaznak különbözö genisztein vegyületeket. Tizenkét vizsgált meggyfajta közül négyben egyértelmüen azonosítható volt a genisztein-7-O-glükozid (genisztin) és a genisztein aglikon Ez a négy fajta a „Pipacs1”, „Kántorjánosi”, „Debreceni bőtermő” és „Éva” voltak. A vizsgált meggyfajták közül kiemelendő a „Pipacs1”, mely 100 g nedves meggyre vonatkoztatva mintegy 4,5 mg genisztin és 1,4 mg genisztein aglikont tartalmaz. A második legtöbb izoflavon a „Kántorjánosi” fajtában volt. Az ebben mért izoflavon-tartalom mintegy tizede volt a „Pipacs1” fajtában megtalálhatónak [ABRANKÓ et al., 2014]. Ezek az értékek összevethetők bizonyos hüvelyesekben mért értékekkel. 
A flavanolok mind monomer (katekin), mind polimer formában (proantocianidinek) léteznek. A katekin és epikatekin a fö flavanolok a gyümölcsökben, míg a gallokatekin, epigallokatekin és epigallokatekin- gallátok bizonyos hüvelyes növények magjában, a szőlőben, és a teában találhatók meg [ARTS et al., 2000b; ARTS et al., 2000a]. A zöld tea és a csokoládé számít a leggazdagabb forrásoknak [LAKENBRINK et al., 2000]. A fekete tea kevesebb monomer flavanolt tartalmaz, melyek oxidálódnak a tealevelek "fermentációja" alatt. A katekinek a vörösborban is jelen vannak legfeljebb 300 mg/liter mennyiségben [MANACH et al., 2004]. Emellett megtalálhatók számos egyéb gyümölcsben is. Ezek közül az egyik leggazdagabb flavonol forrás a sárgabarack, mely akár $250 \mathrm{mg} / \mathrm{kg}$ friss tömeg koncentrációban is tartalmazhatja ezeket a komponenseket [MANACH et al., 2004]. A flavan oligomerek (proantocianidinek) az almában, szőlőben, málnában, datolyában, fekete ribizliben illetve cirok és árpa szemekben vannak jelen [FRANKE et al., 1994]. A flavonoidok más osztályaival szemben, a flavanolok nem glikoziláltak az élelmiszerekben.

Az antocianinokból hatalmas választék található meg a természetben. A fö különbség köztük a hidroxilált csoportok illetve a kapcsolódó cukormolekulák száma és természete [KONG et al., 2003]. Eddig több mint 500 különböző antocianinról és 23 antocianidinról írtak [ANDERSEN \& MARKHAM, 2006; KONG et al., 2003; REIN, 2005 ] melyek közül csak hat a leggyakoribb a növényekben. Ezek a pelargonidin (Pg), peonidin (Pn), cianidin (Cy), miricetin ( $\mathrm{Mv})$, petunidin (Pt) és a delfinidin (Dp) [CLIFFORD, 2000]. Ezek közül is a három nem metilezett antocianidin (Cy, Dp és Pg) cukorszármazékai a leggyakoribbak a természetben. 80\%-uk színes levelekben, 69\%-uk gyümölcsökben, 50\%-uk virágokban található meg [DEY \& HARBORNE, 1993]. Az antocianidineket és glikozidjaikat nagy mennyiségben tartalmazzák a bogyós gyümölcsök és a vörös szőlö [HASLAM, 1989]. Elsősorban a gyümölcsök héjában találhatók meg, kivéve bizonyos típusú piros gyümölcsöket, melyeknél a gyümölcshúsban is előfordulnak (pl.: cseresznye és eper). Ezeken kívül megtalálhatóak a vörösborban, illetve bizonyos gabonafajtákban, leveles és gyökérzöldségekben (padlizsán, káposzta, bab, hagyma, retek). A cianidin a legáltalánosabb antocianidin az élelmiszerekben. Az élelmiszerek antocianin tartalma általában arányos a színintenzitással és akár a 2-4 g/kg-ot is elérhetik. Általában az értékek a gyümölcs érésével növekednek [CLIFFORD, 2000].

A fenolos savak közül a galluszsav a leggyakoribb, és általában komplex cukorészterként jelenik meg a gallo-tanninokban, de ezek csak korlátozott mértékben találhatóak meg az étrendi összetevők között. Nem-cukor galloil észterek megtalálhatóak a szőlőben, a borban, a mangóban, a zöld teában és a fekete teában, melyek így a galluszsav fő forrásai az emberi étrendben. Az ellágsav és az ellagitanninok megtalálhatóak a málnában (Rubus idaeus L.) és az eperben (Fragaria ananassa Duch.), de jelen vannak számos más gyümölcsben is, mint a gránátalma (Punica 
granatum L.), a szeder (Rubus spp. L.), a datolyaszilva (Diospyros kaki T.), valamint a dió (Juglans regia L.), a mogyoró (Corylus avellana L.) illetve a tölgyhordóban érlelt borokban is [CROZIER et al., 2009]. A leggyakoribb hidroxi-fahéjsavak a p-kumársav, a kávésav, a ferulsav és szinapinsav, melyek közül a kávésav van jelen a legnagyobb mennyiségben. Ezek konjugátumok formájában fordulnak elő, például borkősavval vagy kínasavval, melyeket együttesen klorogénsavaknak hívnak. A klorogénsavak, elsősorban a 3-O- , 4-O- és az 5-O-kaffeoilkínasavak, melyek kb. 10\%-ban vannak jelen a zöld robusta kávészemekben (a Coffea canephora P. ex Fr. feldolgozott magjában). A rendszeres kávé fogyasztók napi bevitele meghaladhatja az 1 g-ot, mely így sok ember számára a fó étrendi fenolok egyike lesz [CROZIER et al., 2009; ASHIHARA, 2006].

A fenolos szekoiridoidok legismertebb előfodulása a természetben az olívabogyó illetve az olívaolajok. Mi több, Silva és mtsai kizárólag az olajfafélék családjához rendeli ezen komponensek jelenlétét [SILVA et al., 2010]. A legfontosabb szekoiridoidok, melyek a szüz olívaolajban jelen vannak, a dekarboximetil-elenolsav dialdehid formája mely egy hidroxi-tiroszolhoz vagy egy tiroszolhoz kapcsolódik, továbbá az oleuropein aglikon, a ligsztrozid aglikon, ezek dialdehid formája, illetve maga az oleuropein. A fenolos szekoiridoidok - a lignánokkal együtt - a fenolos komponensek legnagyobb hányadát teszik ki az olívaolajban. Owen és mtsai 27,72 mg / kg összes szekoiridoidot mértek a szüz olívaolajban [OWEN et al., 2000]. Ezek közül az oleuropein a legjelentősebb polifenolos komponens, mely az olívabogyó kissé kesernyés ízét adja. A bogyók oleuropein tartalma érésük elörehaladtával folyamatosan csökken. Ennek mértéke az olajbogyók illetve az olajfa fajtájától is függ [ESTI et al., 1998; OMAR, 2010].

\subsection{Vizsgált élelmi növények és a bennük található polifenolok bemutatása}

\subsubsection{Kakukkfü (Thymus vulgaris $\mathrm{L}$.}

A kerti kakukkfü (Thymus vulgaris L.) rendszertani besorolása szerint a Lamiaceae család tagja, évelö, örökzöld félcserje. Alul fásodó, felemelkedő szára 25-40 cm. Keresztben átellenesen elhelyezkedő levelei lándzsa alakúak, a fonákjukon molyhos levelek széle a fonák irányába visszagöngyölt. Virágzata szaggatott álfüzér, a virágok színe lilásrózsaszín, termése sötétbarna makkocska [SIMON, 2000]. A kerti kakukkfü a Mediterrán térségből származik, a Földközi-tenger nyugati területein, sziklagyepekben és a mediterrán macchiákban őshonos. Hazánkban csak termesztésben fordul elő, néha elvadul. A kerti kakukkfü elsősorban a benne található illóolajok miatt hasznos növény. Az illóolaj komponensek felelősek a kerti kakukkfü tipikus füszeres 
aromájáért. A legtöbb illó komponens a kakukkfü olajból a timollal együtt a monoterpének közé tartozik, mely a legnagyobb arányban van jelen (30-55\%) [PETER, 2004]. Ezeket az illó komponenseket és a hatásukat már számos tanulmányban igazolták [DORMAN et al., 2000; HUDAIB et al., 2002; LEE et al., 2005]. Amellett hogy aromanövény, a kerti kakukkfünek már számos gyógyhatású tulajdonságát és egészségre jótékony hatását leírták mint pl. emésztést segítő hatás, gyulladáscsökkentő hatás, mikrobaölő hatás, vérnyomás csökkentő, antimutagén, véralvadásgátló és rákos folyamatok kialakulását csökkentő hatás [CAI et al., 2004; NAEMURA et al., 2008]. Kivonatai továbbá használatosak emésztési zavarok és más bélrendszeri zavarok kezelésére, köhögésre, hörgőgyulladásra, gégegyulladásra de használják kisebb sebek leápolására és a száj higiéniájához is [FECKA \& TUREK, 2008]. Megjegyzendő ugyanakkor, hogy a kakukkfü számos jótékony hatása nem köthető egyértelmủen a leginkább tanulmányozott illóolajokhoz. Számos irodalom írta le, hogy a közönséges kakukkfü nagyon sok olyan vízoldható komponensben gazdag, mint a flavonoidok és a fenolos savak [MIURA \& NAKATANI, 1989; VILA, 2002]. Mindez összhangban van azzal, hogy ezekben a növényekben jelentős antioxidáns kapacitásokat mértek. Ugyanakkor fontos azt megjegyezni, hogy ez a tényszerü egybeesés nem jelenti feltétlenül azt, hogy a bennük lévő fitokemikáliák a kémiai tesztekben mutatott antioxidáns sajátságaik alapján fejtik ki jótékony hatásukat az emberi szervezetre. Azaz az antioxidáns sajátságok önmagukban nem feltétlenül nyújtanak kielégítő magyarázatot a jótékony hatásokra. A flavonoidokon belül az apigenin és a luteolin a fő komponens, míg a fenolos savak közül főként a rozmaringsav jelentős. A kvantitatív adatok a rozmaringsavra 0,15 és 2,6\% között mozognak. Továbbá néhány szabad fenolos savat is kimutattak kakukkfüböl, mint például a kávésavat, a p-kumársavat, a sziringinsavat és a ferulasavat [PETER, 2004].

A gyógynövények és füszerek nyers kivonatai és az olyan egyéb növényanyagok iránt, melyek fenolos komponensekben gazdagok (mint a kakukkfü), az élelmiszeripar egyre nagyobb érdeklődést mutat antioxidáns sajátságuk miatt, mivel késleltetik a lipidek oxidatív bomlását és így javítják az élelmiszerek minőségét és tápértékét. Adalékanyagként, például napraforgómag olajban, segít javítani a hőtürést és a stabilitást a lipidek oxidációjának megfékezése által az élelmiszerfeldolgozás során [BENSMIRA et al., 2007; ZABOROWSKA et al., 2012].

Annak érdekében, hogy stabil termékeket állítsanak elö, a legtöbb kakukkfüvet szárítják a további használat vagy feldolgozás előtt, mert ez az eljárás gátolja a mikrobák növekedését és megelőz számos biológiai változást [HOSSAIN et al., 2010]. 


\subsubsection{Szurokfü (Origanum vulgare L.)}

A szurokfü (Origanum vulgare L.), melyet vadmajoránnának, közönséges szurokfünek, illetve latin nevéből adódóan újabban oregánónak is neveznek, a szurokfüvek nemzetségébe tartozó füszer és gyógynövény, mely szintén egyike a több mint 200 nemzetséget magába foglaló Lamiaceae (magyarul árvacsalánfélék vagy ajakosok) családnak. A szurokfüvet általában évelő növénynek vagy félcserjének tekintik, melynek kúszó gyökerei, szőrös levelei és elágazó fás szára van. [GRIEVE, 1992] A Földközi-tenger és Eurázsia területén őshonos, hegyvidéki területeken nő, a sziklás, meszes talajt kedveli. Neve is erre utal, mely a görög oros (ami hegyet, dombot jelent) illetve ganos (azaz dísz, díszítő) szavakból áll [KINTZIOS, 2002]. Egyes fajok halmokba rendeződve 2-3 cm magasra nőnek, míg mások akár $39 \mathrm{~cm}$ magasak is lehetnek [TUCKER \& DEBAGGIO, 2000]. A mérsékelt éghajlaton a virágzási időszak június végétől augusztusig tart. Minden virág négy kis vetőmag-szerü képződményt termel. A levélzet kis mirigyeket tartalmaz, melyekben az illóolajat tárolja, mely megadja a növényre jellemző aroma- és ízvilágot [SIMON, 2000].

A Földközi-tenger térségében és Eurázsiában öshonos Origanum fajokat Egyiptomban is termesztették már 3000 évvel ezelőtt és az ókori görögök is használták. Az elmúlt 150 évben több, mint 300 tudományos nevet adtak, kevesebb, mint 70 jelenleg ismert Origanum fajnak, alfajnak, fajtáknak és hibrideknek. Az Origanum nemzetségen belül, és a sokszínü morfológiai karakter alapján, mint például a hosszú szár, a levelek száma, kocsánytalan mirigyek a leveleken, az ágacskák elrendezése, száma és hossza, Ietswaart (1980) 10 szekciót, 38 fajt, 6 alfajt és 17 hibridet ismert fel [IETSWAART \& IETSWAART, 1980]. Azóta - a jelenlegi becslések szerint - 44 faj, 6 alfaj, 3 botanikai fajta és 18 természetben előforduló hibrid van besorolva [KINTZIOS, 2002]. Mivel az Origanum taxonok nagyon változóak, és könnyen kereszteződnek, több száz besorolatlan hibrid nő a kertekben, melyeket húshoz, kolbászhoz, salátákhoz, párolt ételekhez, öntetekhez és levesekhez használnak. A különböző változatok közvetlen közelsége a kereszteződést csak méginkább elősegíti, ami a vadonban nem fordul elő ilyen nagy arányban. Ebből is látszik, hogy az Origanum vulgare L. a leginkább változékony faj a nemzetségben, mégis az egyetlen általánosan köztudott név a legtöbb európai országban az „oregánó” [TUCKER \& MACIARELLO, 1994]. Magyarországon sokak számára az sem ismert, hogy az oregánó és a szurokfü egyazon növényt jelöli.

Az élelmiszeripar ételek és italok elkészítésénél is használja az oregánót, valamint a kozmetikumok előállításánál is közkedvelt. Oregánó olajat használnak szeszes italokhoz, sütőipari termékekhez, hús- és húskészítményekhez, füszerekhez és ételízesítőkhöz, tejtermékekhez, a 
feldolgozott zöldség-, snack ételekhez, illetve zsírokhoz, olajokhoz. Ez a leggyakoribb füszer a pizzán. Fekete borssal együtt, fontos összetevője az önteteknek és jó helyettesítője az asztali sónak [KINTZIOS, 2002]. Az oregánónak elsődleges szerepe van a mérsékeltövi kulináris gyógynövények világkereskedelmében [OLIVER, 1994]. Gyógynövényként - a kakukkfühöz hasonlóan - az egészségre számos pozitív hatással bír, melyet a legtöbb esetben a benne található illóolajoknak tulajdonítanak. Az oregánóról szóló cikkek nagy része ezekkel a komponensekkel foglalkozik, míg a fenolos komponensekről sokkal kevesebb információ áll rendelkezésre. Pedig polifenolos komponensekben is gazdag. Már több, mint száz nem illó komponenst határoztak meg ebből a növényből, beleértve a flavonoidokat, fenolos savakat, továbbá depszideket és origanoszideket is. Ahogy azt fent olvashattuk, a polifenolos komponensek is számos pozitív élettani hatással rendelkeznek így ezek is hozzájárulnak ezen növény egészségre gyakorolt jótékony hatásához [SHETTY, 1997]. A fenolos savak közül a rozmaringsav található meg a legnagyobb mennyiségben, mely gyulladáscsökkentő [HUANG et al., 2009], antimutagén [FURTADO et al., 2008], segít az Alzheimer kór [HAMAGUCHI et al., 2009] megelőzésében és csökkenti a bélrendszeri rákos folyamatok kialakulásának kockázatát [XAVIER et al., 2009]. A flavonoidok közül a leggyakrabban előforduló komponensek a luteolin és az apigenin. [GREVSEN et al., 2009] Gazdasági jelentősége ellenére az Origanum nemzetséget gyakran kihasználatlan rendszertani egységnek tekintik, abban az értelemben, hogy a genetikai erőforrásait, változékonyságát és az ebből fakadó felhasználási lehetőségeket, még nem tárták fel teljesen [D’ANTUONO et al., 2000].

\subsubsection{Olíva (Olea europaea L.)}

Az olíva (latin nevén Olea europaea L.) az Oleaceae családba tartozó növényfajta, mely a mediterrán országokban őshonos. Több mint 30 alfaja ismert. Az olívafa középmagas, maximum 10 méterre növő fafajta, barázdált törzzsel, mely a mediterrán térség száraz, szubtrópikus klímáját kedveli. Jól alkalmazkodott az extrém környezeti viszonyokhoz is, de sok napfényt és jól szellőző talajt igényel. Gyümölcse, az olívabogyó a Földközi-tenger térségében az olívaolaj forrásaként nagy jelentőségü. Az olívafa termőképessége váltakozó, azaz ha az egyik évben sok termést hozott, a következőben kevesebbet fog. Az olíva az Oleaceae család egyetlen, ehető gyümölccsel rendelkező tagja. Olívabogyója nem csak gasztromómiai értéke, hanem páratlan beltartalmi tulajdonságai miatt is érdekes [GUTIÉRREZ \& CARRETERO, 2009]. Az olívaolaj, átlátszó, sárgás, aromás, folyékony növényi zsiradék, melyet az olíva gyümölcsből egyszerü préseléssel nyernek ki. Szokatlan dolog, hogy növényi olajat a gyümölcshúsból lehessen kinyerni, hiszen a többi gyümölcs esetében erre a célra a magot használják fel. A szüz olívaolajat a gyümölcsből 
nyerik ki mechanikai vagy egyéb fizikai módon, föleg olyan körülmények között, ami még nem változtatja meg az olaj kémiai tulajdonságait. Az olívaolajok fajtáit és definícióját Európai Uniós szabályzatokban határozták meg. Ezek szerint hat fő csoportot különítenek el, mint szüz olívaolaj (ezen belül: extra szüz, szüz és lampante), finomított olívaolaj, finomított olívaolajból és szüz olívaolajokból álló kevert olívaolaj, nyers olívamaradék-olaj, finomított olívamaradék-olaj, olívamaradék-olaj. Az extra szüz olívaolaj a lehető legnagyobb mértékben savmentes, amelynek olajsavban kifejezett savtartalma 100 grammonként legfeljebb 0,8 gramm, míg a szüz olívaolaj esetén ez legfeljebb 2 gramm [VLAHOV et al., 2010].

Számos tanulmány erősítette már meg, hogy az extra szüz olívaolaj fogyasztás korrelál a kardiovaszkuláris -, [FITO et al., 2007] a neurodegeneratív betegségek [MENENDEZ et al., 2008; SCARMEAS et al., 2006; TRICHOPOULOU et al., 2003] és bizonyos típusú rákos megbetegedések [SUÁREZ et al., 2008] alacsonyabb kialakulási kockázatával [OMAR, 2010]. Emellett gyulladáscsökkentő, antitrombotikus, vérnyomáscsökkentő és értágító hatással rendelkezik mind emberekben, mind állatokban [PEREZ-JIMENEZ, 2005; COVAS, 2007; PÉREZ-JIMÉNEZ et al., 2007]. Az olívaolaj a szervezet számára esszenciális telítetlen zsírsavakat tartalmaz: linolsavat, linolénsavat és arachidonsavat (F-vitaminnak is nevezik ezeket a zsírsavakat). De a zsírsavak közül az olajsav van jelen a legnagyobb koncentrációban (68-81,5\%) [GUTIÉRREZ \& CARRETERO, 2009; RAMIREZ-TORTOSA et al., 2006]. További hasznos alkotói közül kiemelendő az A-, D-, E-vitamin és a béta-karotin, valamint a flavonoidok és egyéb fenolos komponensek. Ez utóbbiak közül mindenképpen meg kell említeni a leggyakrabban előforduló fenolos szekoiridoid származékokat, ezen belül pedig a legnagyobb mennyiségben jelen lévő oleuropein molekulát [BIANCO \& UCCELLA, 2000; PÉREZ et al., 2005; RYAN \& ROBARDS, 1998; SAVARESE et al., 2007].

Az olívában található polifenolok kapcsán külön kiemelendő, hogy az EU Élelmiszerbiztonsági Hatósága (European Food Safety Authority, EFSA) által elfogadott, az egészségre vonatkozó és a polifenolokról szóló állítások közül, egyedül a hidroxi-tiroszolról és származékairól (első sorban az oleuropeinről) szóló az elfogadott és használható. Az állítás a következő: „Az olívaolajban lévő polifenolok segítenek a vér lipidkészletének oxitatív stressz elleni védelmében.” Fontos kitétel, hogy ez a kijelentés kizárólag azokra az olívaolajokra írható, melyek 20 g-jában minimum 5 mg hidroxi-tiroszol illetve ennek származékai (például oleuropein komplex és tiroszol) találhatóak. Annak érdekében, hogy ez az állítás használható lehessen, hozzá kell tenni, hogy a jótékony hatás eléréséhez az ajánlott adag napi 20 g olívaolaj. A fenti szabályozás tükrében különösen tanulságos, hogy míg számos tanulmány foglalkozik az olívaolajjal, olívabogyóval és a gyártási maradékkal [CARDOSO et al., 2011; VINHA et al., 2005], az olíva termékek polifenoljairól meglévő 
ismereteink még mindig hiányosak. Az elmondható, hogy a hidroxi-tiroszol és tiroszol mellett számos egyéb polifenolt (vanilinsav, kávésav, sziringinsav, p-kumársav, ferulasav, luteolin, apigenin) vizsgáltak célzottan és mutatták ki jelenlétüket olívaolajban. Ugyanakkor ismert, hogy az ilyen célzott mérések csak a szabad formák kimutatására alkalmasak. Mindeközben az olívaolajban megtalálható szabad tiroszol és hidroxi-tiroszol kis koncentrációban van jelen és az észterszármazékaik jóval nagyobb arányban fordulnak elő. A tiroszol fő származéka az oleocantal és a ligsztrozid aglikon. A hidroxi-tiroszol pedig fóleg oleacein formában, illetve oleuropein aglikonként van jelen.

Az oleuropein vizsgálata ugyanakkor nem egyszerü feladat, melynek oka, hogy az olíva polifenolkészlete összetett és részletes tanulmányozásához nagy felbontású kromatográfia és szelektív technikák szükségesek. Például Fu és mtsai [FU et al., 2009] valamint legújabban GilbertLópez és mtsai. [GILBERT-LÓPEZ et al., 2014] oleuropein aglikon és ligsztrozid aglikonok nem célzott vizsgálata során e vegyületek számos izomer formáját feltételezték, de ezeket igazolni nem tudták. Egy másik tanulmány arról számol be, hogy a legáltalánosabban elterjedt minta-előkészítési eljárások eredményezik a mérések során tapasztalható számos oleuropein formát [KARKOULA et al., 2014]. Az olíva kapcsán szintén megemlítendő, hogy csak kevés munka született az olívafa levelében található fenolos komponensek meghatározásáról [BRIANTE et al., 2002; PAIVAMARTINS \& PINTO, 2008].

\subsubsection{Meggy (Prunus cerasus L.)}

A meggy a Rosaceae család Prunoideae alcsaládjába tartozik és feltételezések szerint a vadon termő csepleszmeggy ( $P$. fruticosa Pall.) és a cseresznye tetraploid $(2 \mathrm{n}=32)$ fajhibridje [DIRLEWANGER et al., 2009]. A magyarországi, 2005. évi 48082 t összes termés 48\%-át friss gyümölcsként, a maradék 52\%-ot feldolgozva értékesítették [KSH, 2006]. Termése különösen a feldolgozóipar számára értékes: befőtt, dzsem, ivólé, szörp, bor és likőr, gyorsfagyasztott natúr meggy, aszalvány, gyümölcskrém stb. készül belőle.

A meggy polifenoljai közül legismertebbek a meggyek színét adó antocianinok [BONERZ et al., 2007; CHAOVANALIKIT \& WROLSTAD, 2004]. A meggy antocianin glükozidjairól jelentős mértékü ciklooxigenáz-gátlást mutattak ki, melyekről később igazolták, hogy kísérleti állatokban hatékonyan csökkentik a gyulladásos eredetü fájdalomérzetet [TALL et al., 2004]. Ezenkívül in vitro kísérletekben a meggyből izolált antocianin és annak cianidin aglikonja mérsékelte az egér emésztőszervi daganatsejtek és humán vastagbél-daganatsejtek növekedését [KANG et al., 2003]. Az antocianinokon kívül a színtelen flavonoidok és kínasav-származékok is jelentősek 
[PICCOLELLA et al., 2008]. A flavonoidok közül a flavanolok a meghatározó csoport [CHAOVANALIKIT \& WROLSTAD, 2004]. A meggyben található polifenolok kapcsán összességében azonban elmondható, hogy kevés tanulmány foglalkozik ezek molekuláris szintü feltérképezésével és a korábbi tanulmányok legtöbbje a polifenol alkotók antioxidáns tulajdonságaira összpontosít [SASS-KISS et al., 2005]. A Michigan Állami Egyetem munkatársai 1984-ben 'Balaton' néven honosították az 'Újfehértói fürtös’ fajtát. A különböző amerikai meggyfajták között a 'Montmorency' fajtával együtt e fajtával kapcsolatban történt több vizsgálat is, ezért ezek beltartalmi értékeiről tudunk a legtöbbet [BLANDO et al., 2004; KANG et al., 2003; WANG et al., 1997].

\subsubsection{Cseresznye (Prunus avium L.)}

A cseresznye a Rosaceae család Prunoideae alcsaládjába tartozó faj. A magyarországi, 2005. évi 6159 t összes termés 80\%-át friss gyümölcsként, a maradék 20\%-ot feldolgozva értékesítették [KSH, 2006]. A cseresznyéből elsősorban befőtt, a sötét hússzínüekből dzsem készül.

A cseresznye antocianin tartalmának érés alatti változását Serrano és mtsai. (2005) vizsgálták [SERRANO et al., 2005]. Chaovanalikit és Wrolstad (2004) három cseresznyefajta összes antocianin- és összesfenol-tartalmát jellemezték [CHAOVANALIKIT \& WROLSTAD, 2004]. A 'Bing' fajta antocianin tartalma meghaladta a 'Montmorency' meggyfajtáét. A cseresznye polifenol vegyületei közül a hidroxi-cinnamátok voltak meghatározóak, melyek stabilitását a feldolgozás igen kedvezőtlenül befolyásolta [CHAOVANALIKIT \& WROLSTAD, 2004]. A cseresznye klorogénsav-, epikatekin- és rutintartalma összevethető az őszibarack és kajszi gyümölcshúsban mérhető értékekkel, vagy kismértékben meghaladja azt [VEBERIC \& STAMPAR, 2005]. Humán kísérletekkel igazolták, hogy 280 g 'Bing' fajtájú cseresznye elfogyasztása szignifikánsan csökkentette a vizsgált egészséges nők vérplazmájában mérhető húgysav-koncentrációt, ami a cseresznye hatóanyagainak köszvényellenes hatására utal [JACOB et al., 2003].

\subsection{Polifenolok jótékony hatásai}

„Ételed legyen orvosságod, orvosságod legyen ételed!" Hippokratész (Kr.e.:460-359)

A mai táplálkozástudomány elfogadott álláspontja, hogy a polifenolokban gazdag étrend előnyös az emberi egészségre. Epidemiológiai tanulmányok sokasága bizonyítja, hogy a rendszeres gyümölcs- és zöldségfogyasztás jelentősen csökkenti olyan degeneratív betegségek kialakulását, mint a szív- és érrendszeri betegségek vagy a daganatos megbetegedések [DAUCHET et al., 2006; 
DAUCHET \& DALLONGEVILLE, 2008]. Az epidemiológia e területen is értékes eszköz, amely jelentős szerepet játszik az egészségügyi, a táplálkozási tanulmányokban. A cél az, hogy statisztikailag helytálló összefüggés jöjjön létre a lakosság egészségi állapota és egy (vagy több) befolyásoló tényező között.

A polifenolok jótékony hatásaival kapcsolatos legismertebb epidemiológiai vizsgálat eredményeként született meg a közismert „francia paradoxon” kifejezés. Ennek lényege, hogy kimutatások alapján a kardiovaszkuláris betegségekben szenvedők halálozási aránya lényegesen kisebbnek bizonyult a franciáknál, akik egyébként több telített zsírt és koleszterint fogyasztanak, mint a más országokból származó emberek. Ezt a paradoxont, miszerint a szív- érrendszeri betegségek kialakulásában kockázatként jelentkező jelentős zsírfogyasztás ellenére, a franciák kisebb kockázatnak vannak kitéve, a franciákra jellemző átlagon felüli vörösbor fogyasztással, egész pontosan a borral bevitt etil-alkohol jótékony hatásaival magyarázták [RENAUD \& DE LORGERIL, 1992]. Később ezt az álláspontot meghaladta a tudomány és a vörösbor polifenoljai, különösen a transz-rezveratrol kapott kulcsszerepet a jótékony hatások magyarázatakor. Ezeknek az alkotóknak az érfal egészséges állapotának fenntartásában és a trombózis esélyének csökkentésében lehet szerepük [YAMAMOTO et al., 2005].

A kezdeti sikereket és a téma társadalmi népszerüségét meglovagolva, számos kutatás célozta meg a polifenolok jótékony hatásának igazolását. Ennek eredményeképpen a legkülönfélébb növényekre és az azokban található polifenol-tartalomra vonatkozóan közlemények ezrei jelentek meg a témához köthetően. Sajnos ezek jelentős részéről ma már elmondható, hogy ezek csupán az akkoriban kecsegtetően egyszerü bevételeket jelentő polifenolos témájú kutatások kötelező hozadékaként megjelenő publikációs kényszer szülöttjei, valódi tudományos eredményeket nem szolgálnak a polifenolok jótékony hatására vonatkozólag. Ugyanakkor számos általános jellegü és felületes vizsgálat mellett néhány polifenol kapcsán, a jótékony hatások releváns és tudományos módon is bizonyításra kerültek. Ezek közül alább említek néhány önkényesen kiragadott pozitív példát.

Chen és Chen kiváló áttekintő tanulmányban foglalják össze az emlúlt években keletkezett eredményeket a kaempferol jótékony hatásairól. E polifenol kapcsán epidemiológiai vizsgálatok fordított kapcsolatot mutattak ki a bevitel és egyes ráktípusok kialakulásának gyakorisága között. Ennek magyarázatául szolgálhat, hogy a kaempferol segíthet azáltal, hogy felerősíti a szervezet saját antioxidáns védelmét a szabadgyökök ellen, amelyek a rák kialakulását segítik elö. Emellett jelentősen gátolja a rákos sejtek növekedését, a rákos sejtek apoptózisát indukálja, másrészről, megőrzi a normális sejtek életképességét, és bizonyos esetekben védő hatást fejt ki [CHEN \& CHEN, 2013]. 
A kvercetin bevitel és a szív- és érrendszeri betegségek kialakulása között szintén inverz kapcsolatot találtak. A legújabb vizsgálatok szerint ennek hátterében a kvercetin vérnyomáscsökkentő hatása állhat. Emellett, hatásának feltételezett mechanizmusai között van a oxidatív stressz csökkentés, az angiotenzin-konvertáló enzim aktivitás gátlása, érfaltónus-javító hatás, a vaszkuláris simaizomra gyakorolt közvetlen hatás, és/vagy a sejt jelátvitel és a génexpressziót befolyásoló képessége [LARSON et al., 2010].

A geniszteinről is számos irodalomban írnak, mint potenciális terápiás szerről, rákellenes, gyulladásgátló és oszteoporózis ellenes hatásairól. Feltételezhető, hogy több különböző mechanizmuson keresztül apoptózist indukál hematológiás tumor sejteken, miközben védi a normális sejteket a mérgezéstől. In vitro kísérletekben igazolták továbbá, hogy a genisztein az emlö-, prosztata-, hasnyálmirigy-, melanoma, és a veserákos sejtek esetében gátolja a rákos sejt proliferációját [LI et al., 2010]. Továbbá önmagában vagy kombinációban más, a természetben előforduló vegyületekkel a genisztein lehetővé teszi a zsírszövet tömegének csökkentését és javítja az inzulinrezisztencia állapotát, valamint csökkenti annak kockázatát és a 2. típusú diabetes kialakulásának esélyét [BEHLOUL \& WU, 2013].

A fenti példákból is látszik, hogy egyes polifenolokhoz több egymástól független mechanizmus is társítható ezért ezen komponensek egészségre gyakorolt jótékony hatásának megértése rendkívül összetett feladat. A helyzetet tovább bonyolítja, hogy a táplálkozás során nem kizárólag egyféle polifenolt juttatunk a szervezetünkbe. Ezért ezek valódi hatásainak tisztázása rendkívüli kihívást jelent a kutatók számára.

\subsection{Mérési módszerek áttekintése az antioxidáns sajátságok meghatározásától a molekuláris vizsgálatokig}

Mint láttuk, számos polifenol jótékony biológiai hatása tényszerüen igazolt, ugyanakkor a megfigyelt pozitív hatás mögött meghúzódó folyamatok még kevésbé ismertek. Hagyományosan ezeket a hatásokat csak az antioxidáns aktivitásnak tulajdonították. Az étrendi antioxidánsok klasszikus hidrogén-donor aktivitásról szóló, nagyszámú publikáció ellenére ma már a legtöbben úgy vélik, hogy nem valószínü, hogy ez a funkció önmagában képes magyarázni az in vivo körülmények között lévő hatásokat. Ezt a feltevést több érv is alátámasztja:

1.) Az in vivo redox állapot szigorú homeosztatikus szabályozás alatt van egy komplex antioxidáns hálózat által, mely antioxidáns vegyületekkel és antioxidáns enzimekkel vesz részt az endogén antioxidánsok hatékony újrahasznosításában. Ez három védelmi szintet foglal magába: megelőzés, akadályozás és javítás. Az étrendi antioxidánsok szerepe ezekben a folyamatokban még 
nem ismert. Az, hogy a kis molekulájú antioxidánsok, például a fitokemikáliák, mikrotápanyagok és vitaminok szabad gyökfogókként lépnek-e fel in vivo körülmények között még mindig nem megválaszolt.

2.) In vivo körülmények között csak nanomólos vagy mikromólos koncentrációban kimutathatóak az antioxidánsok, különösen a fitokemikáliák és azok metabolitjai, például a plazmában vagy az olyan szervekben, mint az agy, mely egy vagy több nagyságrenddel kisebb, mint a feljegyzett endogén antioxidánsok, mint például a glutation és albumin. A hidroxil gyökök elleni védekezés azonban megköveteli a kis molekulás antioxidánsok magas, millimoláris tartományban lévő koncentrációját. Következésképpen, az étrendi antioxidánsok nem valószínü, hogy kedvező hatást tudnak kifejteni az egész test szintjén, azaz in vivo körülmények között [FRAGA et al., 2010; HOLST \& WILLIAMSON, 2008].

A polifenolok egészségre gyakorolt jótékony hatásáról rendelkezésre álló meggyőző eredmények alapján azt leszögezhetjük, hogy a sok gyümölcsöt és zöldséget fogyasztó emberek vérében bizonyos antioxidáns hatású molekulák koncentrációja nagyobb. De mindez még nem teszi igazolttá, hogy nagy mennyiségű antioxidáns hatású fitokemikália elfogyasztása így direkt módon hatna, antioxidánsként jelenne meg és fejtené ki hatását az emberi szervezetben. Egy tanulmány szerint ugyanis, ha antioxidáns táplálék-kiegészítőt (C-vitamint, E-vitamint vagy $\beta$-karotint) adtak embereknek, a legtöbb esetben hatástalannak vagy kifejezetten károsnak bizonyult. Ezt a jelenséget nevezte Barry Halliwell antioxidáns paradoxonnak [HALLIWELL, 2000]. A jelenség okai ma még nem teljesen ismertek, de a kedvező egészségi hatáshoz egy izolált komponens nem elégséges, az feltehetően a gyümölcsökben és zöldségekben fellelhető több száz fitokemikália együttes, szinergista hatása következtében jön létre. Mindez felhívja a figyelmet arra, hogy a gyümölcs- és zöldségfogyasztás nem cserélhető fel a mégoly gondossággal összeválogatott táplálék-kiegészítő tabletták szedésével. Mindemellett ma már az is elfogadott tény, hogy a zöldség-gyümölcs fogyasztás eredményeképpen megjelenő jótékony hatásokra nem adnak egyértelmü választ az elfogyasztott élelmiszerek kémiai tesztek során mutatott antioxidáns sajátságai.

Ahogy azt az eddigiekben olvashattuk, a flavonoidok elterjedése és terápiás jelentősége egyre nagyobb, így a kutatók érdeklődési körében is egyre nagyobb teret hódít. Nem egyszerüen csak kémiai antioxidánsokról van szó, ezért az antioxidáns tulajdonság még nem elég az egészséget pozitívan befolyásoló hatások magyarázatára, hanem további molekuláris szintü kutatások szükségesek a pontos folyamatok feltárására, a metabolitok követésére és ezen komponensek pontos hatásmechanizmusának tanulmányozására.

Ahhoz, hogy ezeket felfedjük, monitorozni kell ezen flavonoid komponenseket. Azonban ezeket a méréseket megnehezíti a fenolos vegyületek széles skálája és a növényi mátrixok bonyolultsága, 
mely nagy kihívás elé állítja az analitikusokat. További probléma hogy a legtöbb fenolos komponenst kizárólag szén, hidrogén és oxigén építi fel, így néha csak egy atom különbség van, illetve sokszor csak konstitúciós, szerkezetbeli különbség figyelhető meg. Ugyanígy gondot jelent az is, hogy számos esetben - kiváltképp az összetett polifenol-konjugátumok esetén - nem állnak rendelkezésre referencia standardok. Ezért elmondható, hogy még a legkorszerübb analitikai eszközökkel is nehéz lehet megbízhatóan azonosítani ezeket a komponenseket [BARNES et al., 2009].

\subsubsection{Polifenolok vizsgálati módszerei}

A polifenolok analitikai meghatározásával kapcsolatban alapvetően három nagy csoportot különböztetünk meg aszerint, hogy mi az analízis célja [DE RIJKE et al., 2006].

Az első az összes polifenol tartalmat mérő módszerek, ahol a mintában fellehető összes polifenolos komponens együttes meghatározása a cél egy vonatkoztatott mértékegység segítségével. Ilyen például a spektrofotometriás úton történő meghatározás $\lambda=760 \mathrm{~nm}$-en FolinCiocalteu reagens használatával. Ebben az esetben az eredményeket $\mathrm{mg}$ galluszsav/g mértékegységben adják meg [ROBBINS, 2003; ROBARDS \& ANTOLOVICH, 1997; NACZK \& SHAHIDI, 2004].

A második csoport az úgynevezett célkomponens módszerek, ahol egy vagy több előre kiválasztott polifenol minőségi és mennyiségi paramétereire vagyunk kíváncsiak.

A harmadik az úgynevezett kereső vagy screening módszerek, ahol a mintában fellelhető, előre meg nem határozott komponenseket keressük. A profilozó módszerek jellemzője, hogy elsősorban korábbról ismert polifenol alkotók kimutatása a céljuk, de oly módon, hogy nincs előzetes ismeretünk arról, hogy az elvileg fellelhető alkotók csoportjából melyik fordul esetleg elő az adott mintában. A profilozási módszerek további sajátsága, hogy alkalmasnak kell lenniük olyan korábban ismeretlen polifenol alkotók kimutatására is, melyek létezéséről nem volt korábban tudomásunk. Ugyanakkor, az ilyen feltételesen azonosított alkotók kétséget kizáró igazolása általában már nem a polifenol profilozás része.

A molekuláris szintü vizsgálatok kivitelezéséhez természetesen az utóbbi két csoportban említett módszerek nyújtanak segítséget, ezért a továbbiakban ezek bemutatásával foglalkozom. 


\subsection{1.a Minta-elökészítési módszerek}

Az analitikai vizsgálatok első és legfontosabb lépése a minta-előkészítés, melyet kellő gondossággal és körültekintéssel kell megtervezni és véghezvinni, hiszen az ebből fakadó hibákat később már lehetetlen korrigálni és az eredmények téves következtetésekhez vezethetnek.

A polifenolok vizsgálatakor a két legelterjedtebb extrakciós technika a poláris fenolos frakció kinyerésére a folyadék-folyadék extrakció (liquid-liquid extraction, LLE) [MONTEDORO et al., 1993; BRENES et al., 2000; BONOLI et al., 2004; SUÁREZ et al., 2008] illetve a szilárdfázisú extrakció (solid phase extraction, SPE) [BRENES et al., 2000; DE LA TORRE-CARBOT et al., 2005; GUTIÉRREZ et al., 1989; RÍOS et al., 2005]. Számos kísérletben mátrix szilárd-fázisú diszperziót (matrix solid-phase dispersion, MSDP) alkalmaztak [ŽIAKOVÁ et al., 2003; DE RIJKE et al., 2004], a kisebb mintamennyiség és az alacsonyabb oldószer felhasználás miatt. A gyorsított oldószeres extrakció (accelerated solvent extraction, ASE) egy viszonylag új automatizált kinyerési módszer melyet nyomás alatti folyadék extrakciónak (pressurized liquid extraction, PLE) is hívnak. A módszer elve a magas hőmérsékleten (50-200 $\left.{ }^{\circ} \mathrm{C}\right)$ és nyomáson (500-3000 psi) levő körülményeken alapul, rövid intervallumokig (10 perc). Ez egy új minta-elökészítési technika, melyet sikeresen alkalmaztak már néhány vizsgálatban polifenolok kinyerésére [ALONSOSALCES et al., 2001; BOLLING et al., 2009; SUÁREZ et al., 2009]. Ez a módszer lehetővé teszi, hogy az extrakciós oldószer mennyiségét lecsökkentsük, az analízis idejét pedig lerövidítsük [BOLLING et al., 2009]. Ezeken kívül léteznek egyéb minta-előkészítési/tisztítási technikák, mint a szuperkritikus folyadék extrakció (supercritical fluid extraction, SFE), a szilárd-fázisú mikro extrakció (solid-phase microextraction, SPME), melyek szintén megfelelő megoldásokat nyújtanak a polifenolok vizsgálatához [CUYCKENS \& CLAEYS, 2004].

A minta-előkészítési módszer tervezésekor, a vizsgálandó komponensek polaritása döntő szerepet játszik az alkalmazandó kivonószer megválasztásakor. A kevésbé poláris flavonoidok (flavononok, metilezett flavonoidok) szelektív kivonásához akár apoláris szerves oldószereket is használhatunk (például kloroform, etil-acetát). A jóval polárisabb glikozidok és monomer antocianinok kivonásához azonban főként alkoholok (metanol, etanol) illetve alkohol-víz elegyek alkalmasak. Amennyiben antocianinokat is vizsgálni kívánunk, az extrakció hatékonyságának növelése és az antocianinok stabilitásának érdekében a kivonó-oldatba célszerü 1-5\% ecetsavat, vagy hangyasavat keverni [DE RIJKE et al., 2006; DRAGOVIC-UZELAC et al., 2005; HARBAUM et al., 2007; HARNLY et al., 2007; LIN \& HARNLY, 2007]. Az olívabogyót néhány tanulmányban metanollal és etilacetáttal [SAVARESE et al., 2007] vagy metanol:víz 50:50 V/V arányú keverékével, forró extrakcióval [RYAN et al., 2002] készítik elő. Az olívalevelek 
vizsgálatakor metanol [FU et al., 2010], aceton, etanol és ezek vizes formáit $(10-90 \% \mathrm{~V} / \mathrm{V})$ vizsgálták annak érdekében, hogy megtalálják a polifenolos komponensek hatékony extrakciós módját [ALT1OK et al., 2008].

$\mathrm{Az}$ alkalmazandó minta-előkészítési megközelítés főként a vizsgálat céljától függ. Célkomponenseket keresünk, vagy egy általános profilozást akarunk végrehajtani? Egy-egy vegyületcsoportra optimált minta-elökészítési eljárás alkalmazásával bár összpontosítani tudunk az adott vegyületcsoportra, ugyanakkor ezáltal korlátozzuk az optimálisan kinyerhető komponensek sorát [ROBARDS \& ANTOLOVICH, 1997]. Ezért a specifikus, vagy komponenscsoportokra optimált minta-előkészítési eljárások mellett egyre nagyobb teret hódítanak az ún. „általános” eljárások. Ezek jelentősége a kereső/profilozó módszerek esetében meghatározó [HARNLY et al., 2007]. Lényegük, hogy nem egy-egy polifenolra, vagy polifenol osztályra összpontosítunk, hanem a minta-előkészítés eredményeképpen átfogó képet akarunk kapni a mintában megtalálható polifenolokról. Az ilyen módszerekkel szemben támasztott egyik fö kritérium, hogy a lehető legtöbb polifenolra nézve alkalmazható legyen. Másképpen fogalmazva, a lehető legkisebb mértékben torzítsa el a mintára jellemző eredeti polifenol mintázatot. Ehhez ún. „lágy”, „kíméletes”, extrakciót célszerü alkalmazni [HARNLY et al., 2007]. Az ilyen módszerek alkalmazása során feltételezzük, hogy a komponensek nincsenek kovalens kötéssel kötve a mátrixalkotókhoz. Ez jellemző a flavonoidokra és azok polimerjeire, azonban a fenolos savakra nem. A másik fontos kritérium az extrakció során, hogy elkerüljük a kémiai mellékreakciókat, mint az oxidáció vagy a polimerizáció [HARNLY et al., 2007].

$\mathrm{Az}$ irodalomban találunk több olyan, a polifenolok ,általános” minta-előkészítésére kidolgozott módszert, mely alkalmas az élelmi növények széles körének vizsgálatára. Harnly és munkatársai flavonolokat, flavonokat, flavanonokat, flavan-3-olokat, és antocianidineket határoztak meg friss gyümölcsökből, zöldségekből és magvakból az Egyesült Államok Mezőgazdasági Minisztériuma, (USDA) Nemzeti Tápanyag Adatbázisának részére [HARNLY et al., 2006]. Egy másik tanulmányban brazíliai zöldségekben lévő flavonoidokat határoztak meg [ARABBI et al., 2004], máshol pedig gyümölcs és tea flavonoidokat vizsgáltak [MATTILA et al., 2000].

Ezeknél a módszereknél az extraháló oldat valamilyen vízben oldódó (poláris) szerves oldószer és víz keverékéből áll. A szerves oldószer általában metanol, de számos egyéb (aceton, etanol vagy acetonitril) is használatos. Az extrahálószer összetétele szerves oldószertartalomra nézve az 50100\%, miközben savtartalomra vonatkoztatva az 1-7\% közötti értékek a szokásosak. Erős savak (trifluoroecetsav, sósav) vagy gyenge savak (hangyasav, ecetsav) egyaránt eltejedtek. Megjegyzendő azonban, hogy az ásványi savak használata az acilcsoportok hidrolízisét eredményezheti. Az extrakció történhet egy vagy több lépésben, lehet segíteni a hőmérséklet 
emelésével, ultrahangos fürdővel vagy rázatással [LIN \& HARNLY, 2007]. Az extrakció időtartama egy perc és hat óra között változhat, de akár huszonnégy óra is szükséges lehet. Ettől többet nem célszerü alkalmazni, mert nem kívánt változások mehetnek végbe a vizsgálandó vegyületek szerkezetében [HARNLY et al., 2007; NACZK \& SHAHIDI, 2004; ROBBINS, 2003]. Ha olyan polifenolokra vagyunk kíváncsiak, melyek oldhatatlan és/vagy kötött formában vannak jelen a mintában, valamilyen hidrolízises eljárással fel kell őket szabadítani [HARBAUM et al., 2007]. Erre jó példa Franke és csoportja, akik a Hawaii-on termett gyümölcsök és zöldségek flavonoid szintjét hidrolízis után határozták meg [FRANKE et al., 2004].

Végül megemlítendő, hogy az „általános” minta-elökészítési megközelítés egyik hátránya, hogy a vizsgált komponensek egyikére sem optimális az alkalmazott módszer, hiszen egy általánosan alkalmazható módszer mindig kompromisszumok eredményeként jön létre. Mások ugyanis az optimális minta-előkészítési paraméterek fenolos savak, flavonoidok vagy ezek származékainak szabad és/vagy kötött formáinak vizsgálata esetén. Ez azt eredményezi, hogy például az adott oldószerben rosszul oldódó, vagy a mátrixhoz kötött formákat ,általános” módszerekkel nem lehet kinyerni [ROBBINS, 2003] .

\subsection{1.b Kromatográfiás módszerek}

A flavonoid alosztályok és glikozilációs mintázatok erősen korrelálnak a növények rendszertani besorolásával és ez a kémiai tulajdonságaik sokféleségében is megmutatkozik. Ahogy azt feljebb is olvashattuk, az oldhatósági tartomány különbözősége különösen problémás lehet, amikor a flavonoidok kioldása a cél a növényekből, de nagyon hasznos a kromatográfiás elválasztáskor.

A hasonló szerkezeti felépítés miatt az alosztályokon belül az UV és a látható tartományban felvett- illetve a tömegspektrum elég hasonló lehet, de a megfelelő kromatográfiás oszlopok, eluensek, illetve gradiensek kiválaszthatóak úgy, hogy a célkomponensek kis csoportjait elválassza egymástól. A kihívás abban áll, hogy az elválasztás és meghatározás minél szélesebb tartományban legyen alkalmazható, az összes flavonoid alosztályra és a fenolos komponensekre általában. A flavonoid meghatározásról szóló, megjelent módszerek általában egyéni növényanyagokra fókuszálnak (mint pl. a narancs) vagy családokra (pl.: citrusfélék) és ebből kifolyólag a flavonoidoknak csak egy pár alcsoportjára. Ez annak köszönhető, hogy a glikozilált flavonoidok nagy számának ellenére, kevesebb, mint egy tucat (ami két vagy három alcsoportot jelent) van belőlük egy bizonyos növény anyagban. Emiatt a legtöbb módszert csak két vagy három flavonoid alosztály elválasztására dolgozzák ki. 
Napjainkban a nagyhatékonyságú folyadékkromatográfia (angol nevén high-performance liquidchromatography, HPLC) a leggyakrabban használt elválasztási technika a flavonoid analitikában [DE RIJKE et al., 2006], de emellett létezik más, nem túl gyakran használt módszer is, mint amilyen a kapilláris elektroforézis vagy a gázkromatográfia [DE RIJKE et al., 2006; CREGO et al., 2004]. A folyadékkromatográfia esetében az irodalomban túlnyomó többségében olyan cikkeket találunk, ahol fordított fázisú C8-as és C18-as oszlopot használnak [NACZK \& SHAHIDI, 2004; LIN \& HARNLY, 2007; JUSTESEN et al., 1998; HUGHES et al., 2001; HARNLY et al., 2007]. Az általánosan alkalmazott elválasztási eljárás a gradiens elúció [ROBBINS, 2003; DE RIJKE et al., 2006]. A szerves fázis leggyakrabban acetonitril vagy metanol, de egyéb szerves oldószer is lehet, mint például butanol, propanol, etilacetát. Az esetek többségében az eluens tartalmaz valamilyen puffert vagy szerves savat a $\mathrm{pH}$ beállításához és/vagy az ionizáció elősegítéséhez [TRUCHADO et al., 2009; NACZK \& SHAHIDI, 2004; HARNLY et al., 2007]. Abban az esetben, ha a kísérlet célja a mintában található fő polifenolok meghatározása, a kromatográfia időtartama tíz perctöl több óráig is terjedhet [ROBBINS, 2003]. Azonban, ha a minta polifenolos komponens összetételének a feltérképezése a cél, ez az idő jóval hosszabb is lehet.

\subsection{1.c Detektálási módszerek}

A folyadékkromatográfiás technikában különböző detektorokat alkalmaznak. Hagyományos módszerként legszélesebb körben az UV detektorokat alkalmazzák, mivel minden polifenolos komponens rendelkezik legalább egy fenolos gyürüvel, így az UV fény bizonyos tartományában elnyelési maximummal rendelkeznek [DE RIJKE et al., 2006]. Az első maximum a 240-285 nm-es tartományba esik (az „A” gyürünek köszönhetően), a második maximum 300-550 nm tartományban van [NYSTROM et al., 1954]. Az olyan egyszerü szubsztituensek, mint a metil-, metoxi- és nem disszociált hidroxil csoportok általában csak kis változásokat okoznak az abszorpciós maximumban. Diódasoros detektálást alkalmazva, ezért az egyes flavonoid csoportokat jellegzetes elnyelési spektrumaik alapján meg lehet különböztetni egymástól és sok nem polifenol alkotótól, ami fontos kiegészítő módszer lehet a szerkezet meghatározó eljárás során.

Kevésbé elterjedt módszerek közé tartoznak a fluoreszcenciás detektáláson alapuló eljárások, melynek oka az, hogy az ily módon mérhető komponensek száma nagymértékben limitált. A másik nem túl elterjedt módszer az elektrokémiai detektálás. Az összes flavonoid rendelkezik elektroaktivitással, így ezzel a módszerrel is lehet őket mérni, bár a szelektivitása 
természetesen alacsonyabb mint a fluoreszcens technikáké, de a kimutatási határ alacsonyabb [ROBBINS, 2003; DE RIJKE et al., 2006].

Napjainkban a tömegspektrometria (mass spectrometry, MS) a legkorszerübb és legtöbb célra alkalmazható detektálási technika. A folyadékkromatográf és a tömegspektrométer összekapcsolása sokáig nehézségekbe ütközött, mivel a folyadék formában érkező mintát először el kell párologtatni (így az oldószer távozik a rendszerből), majd a gázfázisba került töltött részecskéket, illetve ionokat lehet az analizátorba juttatni. Ezt a műveletet az ionforrás végzi, mely a molekulákból töltött gázfázisú ionokat állít elő. A polifenolok vizsgálatakor az ESI (elecrospray ionisation) a legelterjedtebb [DE RIJKE et al., 2006]. A készülékek és tömegspektrometriás megközelítések kapcsán, a polifenolok esetében a kismolekulák vizsgálatakor általánosan alkalmazott elvek az irányadók. Azaz használhatunk egyszeres tömegspektrométereket (singlestage mass spectrometers, MS), melyek viszonylag olcsók, viszont szelektivitásuk elmarad a tandem tömegspektrométerekétől. Ezek leginkább ismert polifenolok vizsgálatára alkalmazhatók. A tandem készülékek (MS-MS vagy $\mathrm{MS}^{\mathrm{n}}$ ) közül polifenolok profilozó vizsgálatához gyakran alkalmazzák az ioncsapdás analizátort tartalmazó készülékeket. Az egymást követő konszekutív fragmentációs képesség alkalmassá teszi őket összetettebb polifenol glikokonjugátumok szerkezetének felderítésére is. A polifenol glikokonjugátumok jellegzetes fragmentációja specifikus információt nyújt a konjugátumokban megtalálható glikán részről is [LIN \& HARNLY, 2007; DE RIJKE et al., 2006]. A hármas kvadrupól készülékek azonban több eltérő célú pásztázási mód használatát teszik lehetővé, emellett mennyiségi meghatározáshoz a nagyobb linearitási tartomány és a jobb kimutatási képességei miatt, szintén alkalmasabbnak tekinthetők [PRASAIN et al., 2004]. Egy ilyen készülék müködési elvét a következő, 8. ábra szemlélteti.

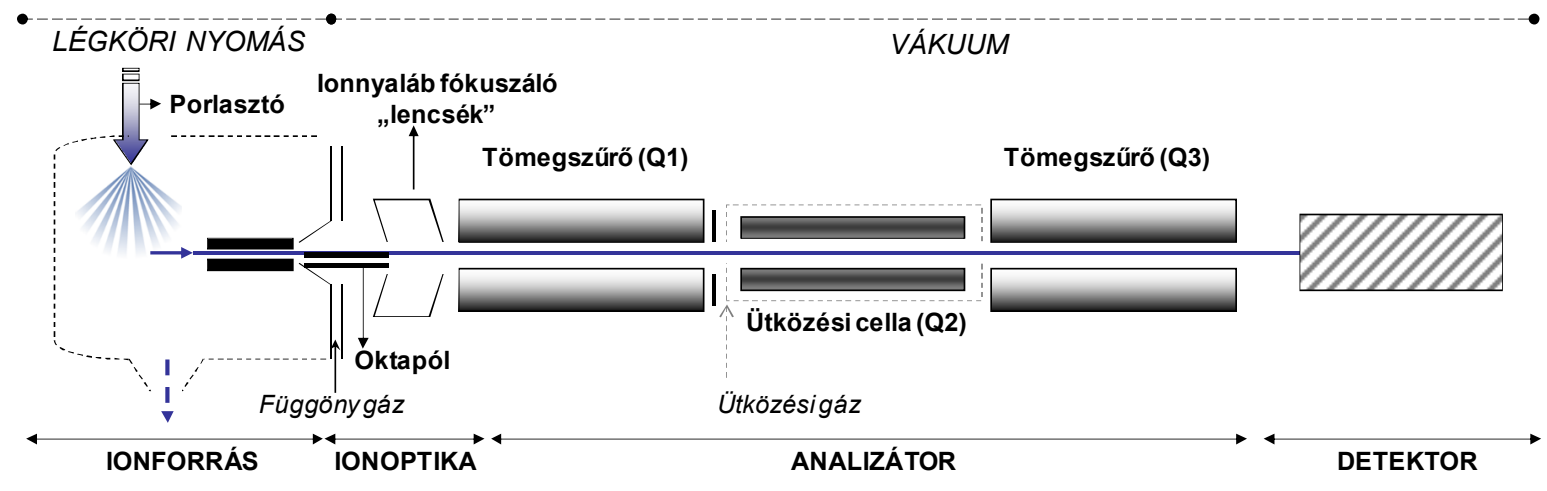

8. ábra: A tandem tömegspektrométer felépitésének sematikus ábrázolása 
Attól függően, hogy milyen vizsgálatra használjuk a két analizáló kvadrupólt, több fajta üzemmódot különböztetünk meg, de általánosságban elmondható, hogy a három kvadrupól közül az első (Q1) választja ki az adott molekulaiont. Ezt követi a Q2 ütközési cella, ahol gázbevezetés (pl.: nitrogén vagy argon) hatására fragmentálódnak a kiválasztott ionok. Majd a harmadik kvadrupól (Q3) a keletkezett fragmensionokat válogatja szét tömeg/töltés $(\mathrm{m} / \mathrm{z})$ alapján. A hármas kvadrupól egyik előnye hogy szükség esetén egyszeres kvadrupólként is müködik. Ekkor nincs fragmentáció, csupán a Q1-es kvadrupól müködik, mely elválasztja a detektálni kívánt molekulaionokat.

A nagy tömegpontosságú és nagy tömegfelbontást eredményező repülési idő tömegspektrométert (time of-flight mass spectrometer, TOF-MS) is egyre szélesebb körben használják számos olyan komplikált komponens jellemzésére, mint a fenolos komponensek [ABRANKO et al., 2011; CARRASCO-PANCORBO et al., 2007] vagy az olívában található szekoiridoidok [FU et al., 2009] és ezek metabolitjai. A repülési idő tömegspektrométerek a felgyorsított ionokat a sebességük alapján választják el egymástól. Az ionforrásba kerülő pozitív töltésű ionokat az ionforrás egy U gyorsítófeszültség bekapcsolásával indítja az analizátorba. A különböző tömegü ionok különböző sebességgel (v1, v2,vvn) repülnek és időben külön-külön érik el a detektort. Az „ $U$ ” a gyorsítófeszültség, ,z” a részecske töltése, ,,m” a tömege. Ez a repülési idő, tehát:

$$
t=\frac{L}{v}=L \sqrt{\frac{m / z}{2 U}}
$$

azaz adott ionforrás - detektor távolság $(L)$ és gyorsítófeszültség mellett csak a fajlagos tömeg $(\mathrm{m} / \mathrm{z})$ függvénye. Tehát minél nagyobb egy egyszeresen töltött ion tömege, annál hosszabb időt vesz igénybe az erőtér mentes övezetben való út. Így a detektorban adott pillanatban mért intenzitás adott ionhoz rendelhető. Ez az analizátor nagyon gyors müködésủ, egy-egy ion repülési ideje $10^{-5}$ $10^{-7} \mathrm{~s}$ között van. Az ionok relatív intenzitása (a legintenzívebb ionok intenzitásának százalékában kifejezett intenzitás) és a fajlagos tömege közötti kapcsolat adja a vegyületre jellemzõ tömegspektrumot. Mivel az időt csak az út megtétele utáni becsapódás alapján tudjuk meghatározni, az analizátor felbontása szempontjából kulcsfontosságú, hogy az ionizáció impulzusszerü legyen. Azonban az azonos $m / z$-hez tartozó ionok is kismértékben különböző energiájúak, s ez a hatás kiszélesíti az ioncsúcsokat. A jelenség csökkenthető, ha az ionok nem egyenes úton repülnek, hanem útjukba „,iontükröt”, ún. reflektront tesznek. A reflektronban a nagyobb energiájú ionok hosszabb pályára kényszerülnek, így a repülési idejük hosszabb lesz, vagyis az energiaszórásból származó hiba csökken. Ennek hatására több mint 10 000-es felbontás 
érhető el [FAY et al., 2010]. A reflektronnal rendelkező repülési idő tömegspektrométer felépítésének sematikus bemutatását a 9 . ábrán láthatjuk.

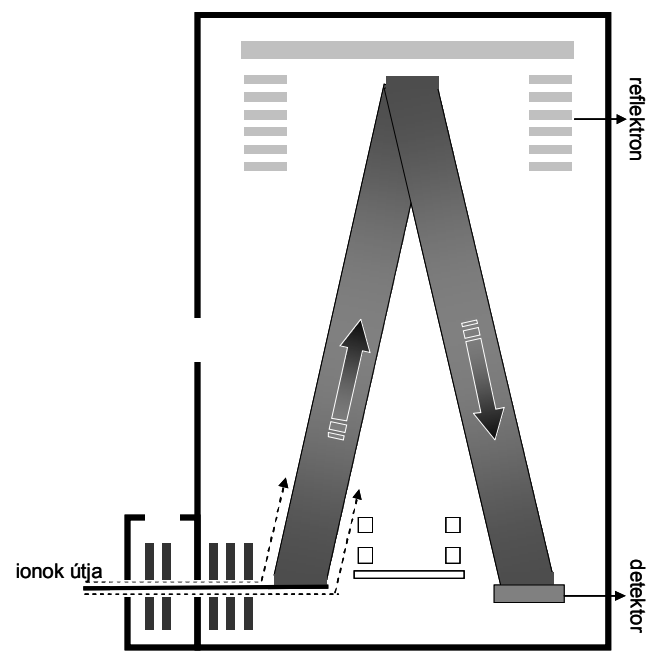

\section{9. ábra: Repülési idö tömegspektrométer felépitésének vázlata}

Azonban ez a technika is rendelkezik azzal a problémával, hogy az azonos összegképlettel rendelkező komponensek között nem tud különbséget tenni. Izomer alkotók azonosításához, mindenképpen szükség van egyedi MS-MS felvételekre, hogy diagnosztikus fragmentációs mintázatuk alapján az alkotókat azonosítani lehessen [BARNES et al., 2009; OLIVEIRA et al., 2001]. 


\section{CÉLKITÜZÉS}

Doktori munkám célja, hogy az élelmiszer- és táplálkozástudományi, valamint a növénybiológiai kutatásokhoz kapcsolódó polifenolvizsgálatok során felmerült néhány elméleti és gyakorlati kérdésre, analitikai eszközök segítségével megoldásokat keressek. Ennek érdekében munkám során tömegspektrométerrel kapcsolt analitikai módszereket alkalmaztam és fejlesztettem. Tevékenységem során három területhez kapcsolódóan végeztem tömegspektrometriás vizsgálatokat és módszerfejlesztéseket.

Elsőként hazai termesztésủ gyógynövények polifenolvizsgálatával foglalkoztam, ahol célom volt:

- A növényi kivonatokban szabad és kötött formában lévő fenolos savak kvantitatív meghatározása. Ezen belül a „timolos” és „nem timolos” kakukkfü populációk, továbbá a közönséges- és görög szurokfü populációk fenolos savas komponenseinek összehasonlítása.

- Továbbá e vizsgálatok kiegészítéseként flavonoid komponensek feltérképezése mindkét növényfaj esetében HPLC-MS-MS screening módszerrel.

Munkám második részében, a spanyolországi ösztöndíjas időszak alatt, az olíva növényben illetve olajban megtalálható oleuropein vizsgálatával foglalkoztam. Ennek kapcsán feladatom volt:

- Az oleuropein aglikon izomereknek feltételezett alkotók pontosabb azonosítása TOF-MS müszerkapcsolással.

- Illetve az olívabogyó, olívalevél és olívaolaj összehasonlítása ezen származékok tekintetében.

Harmadik témakörként a konstitúciós izomériával rendelkező flavonoid aglikonok meghatározásának nehézségeire próbáltam megoldást találni. Ehhez egy olyan HPLC-MS-MS módszer fejlesztése volt a célom mely kellő szelektivitást eredményez izomer aglikonokkal rendelkező flavonoid glikokonjugátumok esetén is. Ennek érdekében célom volt, hogy:

- az izomer aglikonok tömegspektrumait vizsgálva találjak olyan diagnosztikus ionokat, melyek kellő diszkriminációs képességgel bírnak.

- a kidolgozott módszert valódi mintán alkalmazva igazoljam ennek megfelelőségét. 


\section{ANYAG ÉS MÓDSZER}

\subsection{Felhasznált vegyszerek}

Az Gyógynövények fenolos komponenseinek vizsgálata (5.1-es) fejezetben ismertetett méréshez használt vegyszerek:

A polifenolos komponensek gyógynövényekből való meghatározásához használt kristályos fenolos sav (p-kumársav, kávésav, ferulasav, sziringinsav, szinapinsav, klorogénsav, rozmaringsav) és flavonoid standardokat (apigenin, luteolin, miricetin, naringenin, kvercetin, heszperetin, fiszetin, daidzein, genisztein, kaempferol) a Sigma forgalmazta (Sigma-Aldrich ${ }^{\circledR}$, Budapest, Magyarország). Scharlau (Barcelona, Spain) gyártmányú HPLC tisztaságú acetonitrilt, metanolt és hangyasavat használtam. A nagytisztaságú vizet $\left(18 \mathrm{M} \Omega \mathrm{cm}^{-1}\right)$ a Milli-Q rendszer állította elő (Billerica, MA, USA).

Az Olívaolaj oleuropein-származékainak feltérképező vizsgálata HPLC-ESI-TOF-MS technikával (5.2-es) fejezetben ismertetett méréshez használt vegyszerek:

Az olíva termékekből illetve nyersanyagokból végzett kísérlet során a HPLC tisztaságú acetonitril és metanol Merck ${ }^{\circledR}$ (Darmstadt, Germany) gyártmányú volt. Az analitikai tisztaságú ecetsav Fluka ${ }^{\circledR}$ (Buchs, Switzerland) gyártmányú volt. A HPLC tisztaságú víz előállításához Millipore ${ }^{\circledR}$ (Milford, MA, USA) gyártmányú Milli-Q-Plus rendszert alkalmaztunk. Az SPE minta-előkészítéshez a Florisil töltetek (2 g, $50 \mu \mathrm{m}, 12 \mathrm{ml}$ ) Análisis Vínicos (Tomelloso, Ciudad Real, Spain) gyártmányúak voltak, míg a diol tölteteket (Discovery ${ }^{\circledR}$ DSC-Diol SPE Tube $500 \mathrm{mg}, 6 \mathrm{ml}$ ) a Supelco $^{\circledR}$ (Bellefonte, PA, USA) gyártotta, melyeket szerves oldószerekhez, olajokhoz, lipidekhez ajánlanak.

Az Izomer aglikonnal rendelkező flavonoid-glikokonjugátumok szelektív tömegspektrometriás vizsgálata (5.3-as) fejezetben ismertetett méréshez használt vegyszerek.

Az izomer aglikonok együttes mérésére alkalmas módszer kifejlesztéséhez a kísérletekben három antocianin komponens (cianidin, pelargonidin, delfinidin) és glikozidjaik (ideanin (cianidin3-galaktozid), callistephin (pelargonidin-3-O-glükozid), myrtillin (delfinidin-3-O-glükozid)), két flavonol aglikon (kaempferol, kvercetin), a kvercetin glikozidja (kvercetin-3-O-glükozid) és a kaempferol három származéka (kaempferol-glükozid, - rutinozid és robinin (kaempferol-3-Orobinozid-7-O-ramnozid)), két flavon (luteolin, apigenin) és glikozidjaik (luteolin-glükozid, apigenin-7-glükozid), egy flavonon (heszperetin) és egy izoflavon (genisztein) és ezek glikozidjai (heszperidin (heszperetin-rutinozid), genisztin (genisztein-7-glükozid) szerepelt. A kristályos

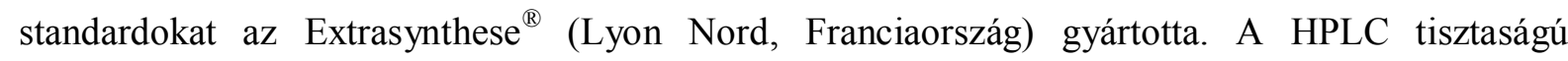


acetonitril, metanol és hangyasav Scharlau ${ }^{\circledR}$ (Barcelona, Spanyolország) gyártmányú volt. Itt is minden mérésnél nagy tisztáságú vizet használtam $\left(18 \mathrm{M} \Omega \mathrm{cm}^{-1}\right)$ melyet a Milli-Q rendszer (Milford, MA, USA) biztosított. A standardokat 1\% hangyasavat tartalmazó metanolban oldottam fel.

\subsection{Vizsgált növények, termékek}

Az 5.1-es fejezetben ismertetett méréshez használt növények.

A Thymus vulgaris L. azaz kerti kakukkfü különböző kemotípusait („timolos”: magas timoltartalmú szelektált populáció és „,nem timolos”: alfa-terpineol illetve alfa-terpinil-acetát kemotípusú szelektált populáció) illetve szurokfü (Origanum vulgare L. subsp. hirtum - görög oregánó, Origanum vulgare L. subsp. vulgare - közönséges szurokfü) állományokat választottuk ki. A minták a teljes virágzás idején lettek összegyűjtve, 2010 májusában, Soroksáron Budapesti Corvinus Egyetem, Gyógy- és Aromanövény Tanszék Kísérleti Gazdaságában. Az összes mintát fütő-hütő termosztátban szárították (Labor Müszeripari Művek, Esztergom, Magyarország) $40{ }^{\circ} \mathrm{C}$-on 3 napig (7,9\%-os víztartalommal). A szárítás után a levelek és a virágok eltávolításra kerültek, a további analízishez.

Az 5.2-es fejezetben használt olívalevél és olívabogyó (Campiña Norte) a spanyolországi Jaén-i Egyetem saját termesztésü olíva fáiról származott. A vizsgált olívaolajok közül a „Fuenroble” márkanévvel jelzett olaj Jaén-tartományból származó olívabogyókból, míg a „Borges” olívaolaj különböző spanyolországi tartományokból származó olívabogyókból készül. Mindkét esetben a gyártók extra szüz olívaolajait használtam.

Az 5.3-as fejezetben ismertetett méréshez használt cseresznye házi termesztésü, míg a meggy, fagyasztott, kereskedelmi forgalomban kapható termék volt. Ebben a fejezetben az 5.1-es fejezetben ismertetett méréshez használt kakukk- és szurokfü fajtákat is felhasználtam.

\subsection{Alkalmazott berendezések}

Az 5.1-es és 5.3-as fejezetben ismertetett méréshez használt müszerek:

A kísérleteket Agilent ${ }^{\circledR}$ (Agilent Technologies, Waldbronn, Germany) 1200 HPLC rendszeren és egy hozzá kapcsolt Applied Biosystems ${ }^{\circledR}$ (Foster City, CA, USA) 3200 Q-Trap hibrid hármas kvadrupól/lineáris ioncsapda MS/MS müszeren végeztem el, melyhez egy Turbo-V® elektroporlasztásos (electrospray, ESI) ionforrást használtam negatív ionizációs módban. 
Az 5.2-es fejezetben ismertetett méréshez használt müszerek:

A fenolos komponensek elválasztását Agilent 1200-as (Agilent Technologies, Santa Clara, CA) HPLC-n végeztem, mely egy vákuumos gázmentesítőt, egy automata mintaadagolót és egy bináris pumpát is tartalmazott. A HPLC rendszer egy Agilent 6220 (Agilent Technologies, Santa Clara, CA) repülési idő (time-of flight, TOF) tömegspektrométerhez volt csatlakoztatva, mely ESI ionforrással volt ellátva.

A bepárlást Caliper Turbovap LV Concentration Workstation (Caliper LifeSciences, Barcelona, Spain) evaporáló készülékkel végeztem. Az ASE minta-előkészítés egy Dionex ${ }^{\circledR}$ ASE 200 (Dionex GmbH, Idstein, Germany) rendszeren történt. Az SPE minta-tisztítást Visiprep SPE vákuum-káddal (Supelco, Bellefonte, PA, USA) végeztem.

\subsection{Minta-elökészités}

Az 5.1-es fejezetben ismertetett vizsgálatnál használt minta-előkészítés.

Vizsgálataimhoz a különböző növényanyagok vizes extraktumát használtam. Ezt a vizes extraktumot a Magyar Gyógyszerkönyv (8. kiadás) [PH.HG., 2004] elöírási alapján kaptuk, azaz $1 \mathrm{~g}$ minta került feloldásra $100 \mathrm{ml}$ forrásban lévő desztillált vízben $\left(\sim 100^{\circ} \mathrm{C}\right)$ majd 24 órára állt. Ezután az extraktumokat szürni kellett 8-12 $\mu \mathrm{m}$-es szürőpapírral majd felhasználásig fagyasztásra kerültek. Az így kapott $40 \mathrm{ml}$ szürletet $5 \mathrm{ml}$ metanol hozzáadása után 5 percig centrifugáltam $6000 \mathrm{rpm}-\mathrm{en}$.

Ezek után annak érdekében, hogy felmérhessem a szabad és származék formájában a mintában lévő fenol savas komponenseket két fajta minta-elökészítést alkalmaztam. Az első lényegét tekintve egy egyszerü hígítás, ahol a felülúszóból nyert $1 \mathrm{ml}$ szürt vizes extraktumhoz

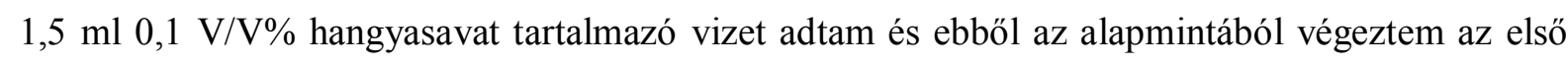
méréseket. Később, a növényben lévő jelentős rozmaringsav koncentráció miatt további százszoros hígítást $(0,1 \mathrm{~V} / \mathrm{V} \%$ hangyasavat tartalmazó vízzel) is el kellett végezni minden minta esetében.

A másik egy hidrolizált minta-előkészítés volt annak érdekében, hogy a konjugátumként jelen lévő fenolos savak felszabadulhassanak és a célkomponens-kereső módszer számára detektálhatóvá váljanak. Ezért Harbaum 2007-es módszere alapján [HARBAUM et al., 2007], a felülúszóból kivett $1 \mathrm{ml}$ extraktumhoz $1 \mathrm{ml} 2 \mathrm{M}$-os $\mathrm{NaOH}$-ot adtam, majd 16 órán át kevertettem mágneses keverőn. Hogy a müszer számára mérhetővé váljon, a pH-t 2-esre állítottam be 0,5 $\mathrm{ml} 50 \% \mathrm{~V} / \mathrm{V}$-os sósav oldattal, majd tízszeres hígítást végeztem el a mintákon. Mindkét minta-előkészítést követően a mintákat $0,22 \mu \mathrm{m}$-es nylon membrán szürőn engedtem át a mérés megkezdése előtt. 
Az 5.2-es fejezetben ismertetett vizsgálatnál használt minta-előkészítés Az extra szüz olívaolajban található fenolos komponenseket szilárd fázisú extrakcióval nyertem ki. Az 500 mg-os 'diol' szilárd fázisú töltetetet elöször $10 \mathrm{ml}$ metanollal majd $10 \mathrm{ml}$ hexánnal kondicionáltam. A 3 g extra szüz olívaolajat $3 \mathrm{ml}$ hexánban oldottam és a kolonnára engedtem. A töltetet ez után háromszor $5 \mathrm{ml}$ hexánnal mostam, hogy eltávolítsam a lipid frakciót, majd szintén háromszor $5 \mathrm{ml}$ metanollal eluáltam. Az összegyüjtött eluátumot szárazra pároltam $\mathrm{N}_{2}$ alatt $28{ }^{\circ} \mathrm{C}$ on. A bepárlási maradékot $1 \mathrm{ml}$ metanolban és $2 \mathrm{ml}$ vízben oldottam fel, majd 0,45 $\mu \mathrm{m}$-es szürőn szürtem át. Az SPE minta-előkészítés sematikus bemutatása a 10. ábrán látható.

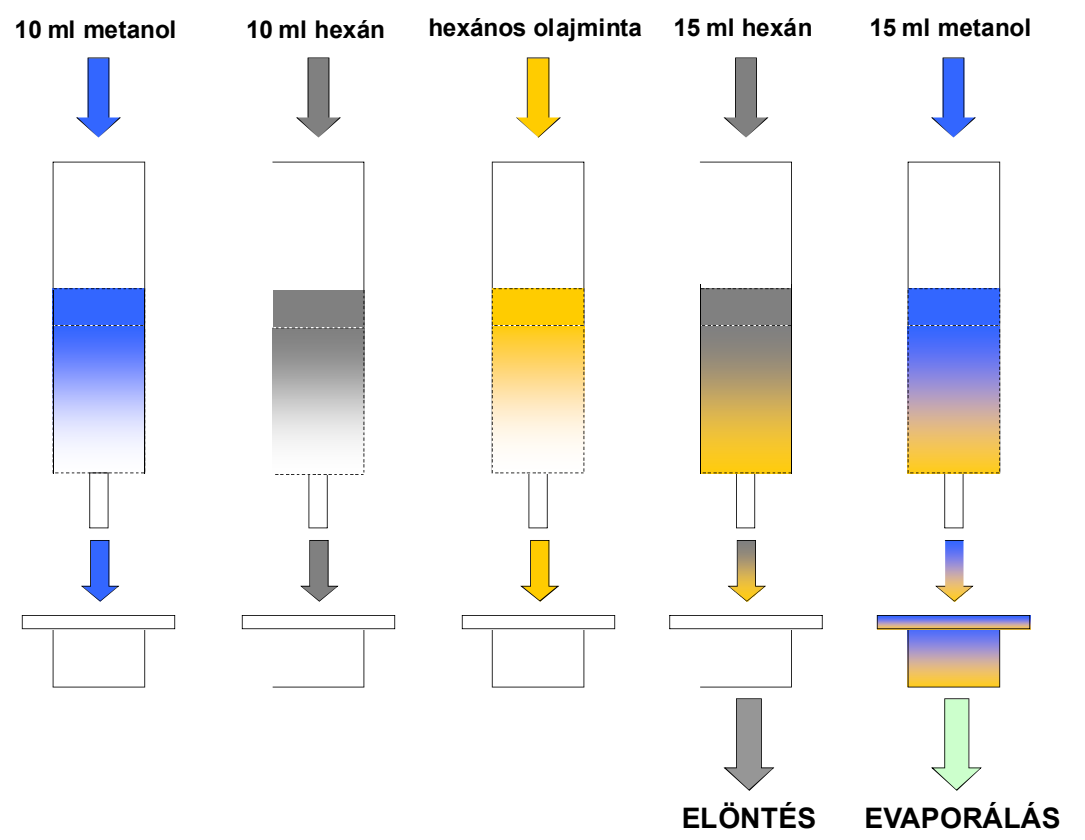

10. ábra: Az 5.2. fejezetben használt SPE minta-elökészités sematikus ábrázolása

Az olívabogyó és olívalevél vizsgálata úgynevezett Accelerated Solvent Extraction (ASE), azaz gyorsított oldószeres extrakciós minta-előkészítéssel, Dionex ASE 200 rendszeren történt. Ennek vázlatos bemutatását a 11. ábra szemlélteti.

A vizsgálathoz $2 \mathrm{~g}$ olívalevelet illetve $3 \mathrm{~g}$ olívabogyót összekevertem $1 \mathrm{~g}$ kovafölddel és $10 \mathrm{ml}$ térfogatú rozsdamentes acél extrakciós cellába helyeztem. A diszperziós adalékanyag hozzáadását - mint amilyen a kovaföld is - az extraháláshoz szükséges oldószer mennyiségének csökkentésére javasolják. 

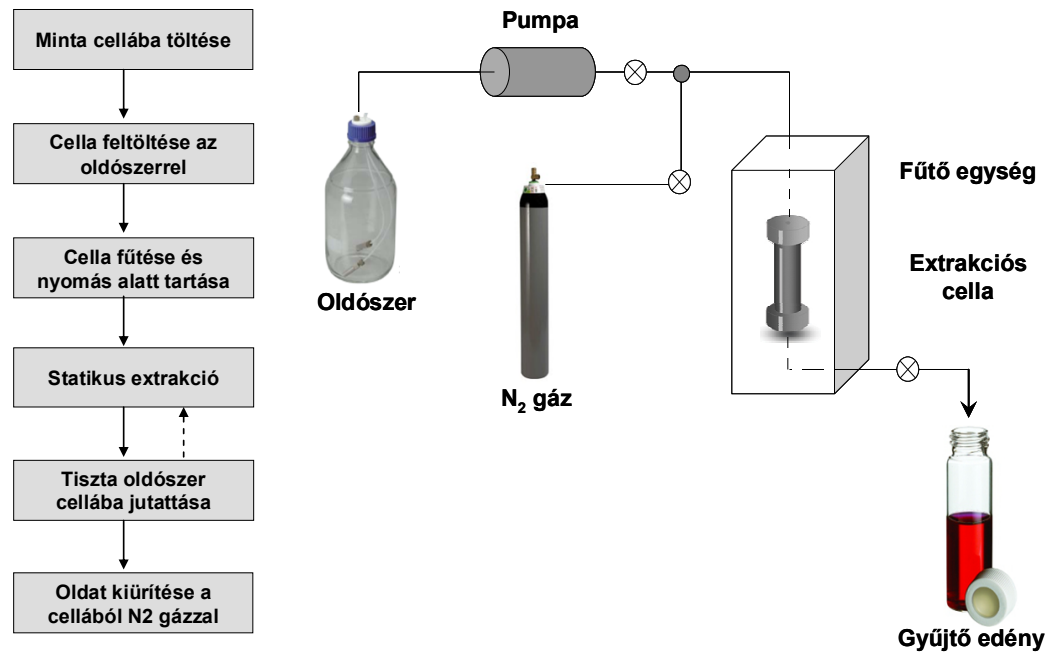

11. ábra: Az ASE minta-elökészités sematikus ábrázolása

Az extrakciós cella alján egy rozsdamentes acél - és egy cellulóz szürőt (Dionex Corp.) helyeztünk el, hogy elkerüljük a lebegő részecskék bejutását a gyüjtő üvegcsébe. Az extrakciós cellát a kör alakú mintatartóba kell helyezni, majd az extrahálást az előzőleg beállított kondíciók szerint elvégezni. A mintát egy extrakciós ciklusban extraháltuk metanol:víz 80:20 V/V elegyével $100{ }^{\circ} \mathrm{C}$-on és 1600 psi nyomáson 5 percig. (A mintát tartalmazó cella előzetes tisztítása az extrakciónál használt oldószer eleggyel, szintén 5 perces ciklussal történt.) Az extrakció után a cella friss extrakciós oldószerrel (az extrakciós cella térfogatának 60\%-ával) és nitrogénárammal volt átöblítve 150 psi nyomáson 90 másodpercig. Az alkalmazott oldószert korábban gázmentesítettük, hogy elkerüljük az analitok oxidációját. Ezt követően $\mathrm{N}_{2}$ árammal a gyüjtő edénybe juttattuk az oldatot. Ezt követte a centrifugálás és bepárlás. Az bepárolt minta vízben való visszaoldása után, az SPE minta-tisztítással fejeződik be a minta-előkészítés.

Az 5.3-as fejezetben ismertetett vizsgálatnál használt minta-előkészítés:

Egy 15 ml-es müanyag centrifugacsőbe 200 mg liofilizált és homogenizált mintát mértem be majd $10 \mathrm{ml} \mathrm{MeOH}: \mathrm{H}_{2} \mathrm{O}: \mathrm{HCOOH}$ 60:39:1 V/V elegyben szuszpendáltam. Ezt egy órára ultrahangos fürdőbe tettem, majd centrifugáltam 6000 rpm-en, 5 percen keresztül. Ezt követően $8 \mathrm{ml}$ felülúszót mértem ki, melyet vákuumban 1,5 ml-re pároltam. A bepárolt mintához $200 \mu \mathrm{l}$ acetonitrilt és $20 \mu \mathrm{l}$ $50 \mathrm{~V} / \mathrm{V} \%$-ban hangyasavat tartalmazó vizet adtam, majd 2 ml-re egészítettem ki vízzel. Végül, 0,45 $\mu \mathrm{m}$-es PTFE szürőn leszürtem. 


\subsection{Kromatográfiás módszerek}

Az 5.1-es fejezetben ismertetett vizsgálatnál használt kromatográfiás módszer:

A fenolos savak kromatográfiás analíziséhez 2,1 mm $\times 50 \mathrm{~mm}$-es Agilent Zorbax Rapid Resolution C18 oszlopot használtam 1,8 $\mu \mathrm{m}$-es szemcsemérettel. Az oszlopot in-line szürőbetéttel védtem. Az elúcióhoz $0,1 \% \mathrm{~V} / \mathrm{V}$ hangyasavat tartalmazó vizet (A eluens) és $0,1 \% \mathrm{~V} / \mathrm{V}$ hangyasavat tartalmazó acetonitrilt (B eluens) használtam oldószerként $400 \mu \mathrm{l} / \mathrm{min}$ áramlási sebességgel. A gradiens program 2\% B-ről indult, majd 2 perc izokratikus futást követően a B eluens aránya egyenletesen emelkedett 30\%-ra 9 perc alatt. A 20. percre ez elérte a 99\%-ot és ez az összetétel maradt 2 percig. Végül, a B-eluenst az eredeti arányra állítottam vissza egy perc alatt és az oszlopot így ekvilibráltam 6 percig.

A flavonoidok vizsgálatához a kromatográfiás oszlop egy Agilent Eclipse XDB-C18 RP 4,6 × 250 mm-es oszlop volt, melynek az átlagos szemcseátmérője $5 \mu \mathrm{m}$. Az „A” csatornán áramló eluens víz volt $0,1 \% \mathrm{~V} / \mathrm{V}$ hangyasav tartalommal, míg a „B” csatornán áramoltatott eluens metanol volt szintén $0,1 \% \mathrm{~V} / \mathrm{V}$-os hangyasavval. A kromatográfiás elválasztás ideje 60 perc volt. Az ez idő alatt alkalmazott gradienst az 1. táblázat szemlélteti. Az injektált mennyiség $10 \mu \mathrm{l}$ volt.

1. táblázat: Az 5.1-es fejezetben, a flavonoidok vizsgálatához használt gradiens módszer

\begin{tabular}{cccc}
\hline idő [min] & A\% & B\% & $\begin{array}{c}\text { áramlási sebesség } \\
{[\mathbf{m l} / \mathbf{m i n}]}\end{array}$ \\
\hline 0,0 & 80 & 20 & 1,0 \\
10,0 & 80 & 20 & 1,0 \\
50,0 & 30 & 70 & 1,0 \\
50,1 & 1 & 99 & 1,0 \\
55,0 & 1 & 99 & 1,0 \\
55,1 & 80 & 20 & 1,0 \\
60,0 & 80 & 20 & 1,0 \\
\hline
\end{tabular}

Az 5.2-es fejezetben ismertetett vizsgálatnál használt kromatográfiás módszer:

Ennél a módszerként álló fázisnak egy fordított-fázisú Agilent Zorbax Eclipse XDB-C18 Rapid Resolution HT $(4,6 \times 150 \mathrm{~mm}, 1,8 \mu \mathrm{m})$ oszlopot alkalmaztam. Eluensként $0,1 \% \mathrm{~V} / \mathrm{V}$ hangyasavat tartalmazó vizet (A eluens) és acetonitrilt (B eluens) alkalmaztam percenként $500 \mu$ l-es áramlási sebességgel. A gradiens program 5\% B eluenssel kezdődött majd 1 perc izokratikus futtatás után elérte a 30\% -ot a 10. percig, majd a 40\% -ot a 40 . percre és a $100 \%$-ot a 45. percnél. Végül, 100\% B eluenssel folytatódott 5 percig majd 10 percre visszaállt a kezdő eluens összetétel. Az oszlophőmérséklet $24^{\circ} \mathrm{C}$-ra volt beállítva, az injektálási térfogat pedig $10 \mu 1$ volt. 
Az 5.3-as fejezetben ismertetett vizsgálatnál használt kromatográfiás módszer:

Ebben a vizsgálatban a kromatográfiához Agilent Zorbax Eclipse XDB-C18 (4,6 × 250 mm, $5 \mu \mathrm{m}$ ) oszlopot használtam. Mozgófázisként $0,5 \% \mathrm{~V} / \mathrm{V}$ hangyasavat tartalmazó vizet (A eluens) illetve $0,5 \% \mathrm{~V} / \mathrm{V}$ hangyasavat tartalmazó acetonitrilt (B eluens) használtam. Az áramlási sebesség $1000 \mu \mathrm{l} / \mathrm{min}$, az injektálás térfogata $50 \mu \mathrm{l}$ volt. A gradiens program $5 \% \mathrm{~B}$ eluens-aránnyal kezdődött, majd 5 perc izokratikus szakasz után lineárisan 30\%-ra emelkedett 9 perc alatt. A tizenötödik percre elérte az 55\%-ot, majd 5 percen belül a 100\%-ot és ezt az arányt tartotta még 3 percig. Végül visszaállítottam a kezdeti arányt egy perc alatt és így ekvilibráltam az oszlopot 10 percig.

\subsection{Tömegspektrometriás módszerek}

Az 5.1 és 5.3-as fejezetekben leírt vizsgálatokban a 2.5.1.c Detektálási módszerek címü fejezetben ismertetett tandem tömegspektrométert használtam, melyre jellemző, hogy a vizsgálat céljától függően különböző üzemmódokban használható. Ezeket a következőkben mutatom be.

$\mathrm{Az}$ egyik lehetséges üzemmód a termékion pásztázás (product ion scan). Ebben az üzemmódban a Q1 kvadrupól csak a megadott tömeg/töltésű molekulaiont engedi át, majd a fragmentálás után kapott töredékeket a Q3 kvadrupól pásztázza (Q3 scan), mely egy fragmension tömegspektrumot eredményez. Ezáltal szerkezeti információkhoz juthatunk, valamint további kvantitatív vizsgálatokhoz itt kiválaszthatók azok a fragmensek, melyek jól jellemzik majd az adott komponenst. A folyamat bemutatása a 12. ábrán látható.

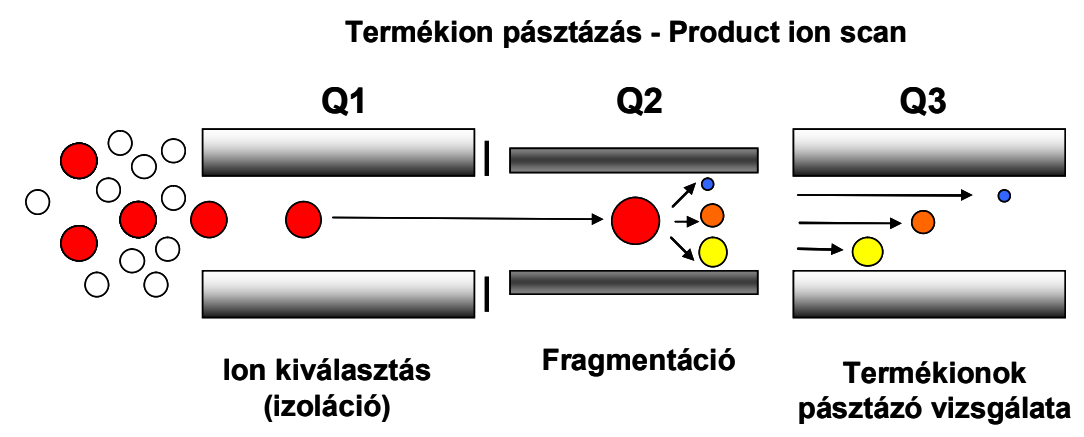

12. ábra: A termékion pásztázás sematikus bemutatása

A következő beállítási mód a prekurzorion pásztázás (precursor ion scan), ahol a Q3 kvadrupól az, ami kiválaszt és csak meghatározott tömeg/töltésü fragmensionokat enged át 
(13. ábra). A Q1 ilyenkor pásztáz, így minden olyan molekulaion azonosítható, melynek ütközése során a Q3-ban megadott és monitorozott fragmension képződik.

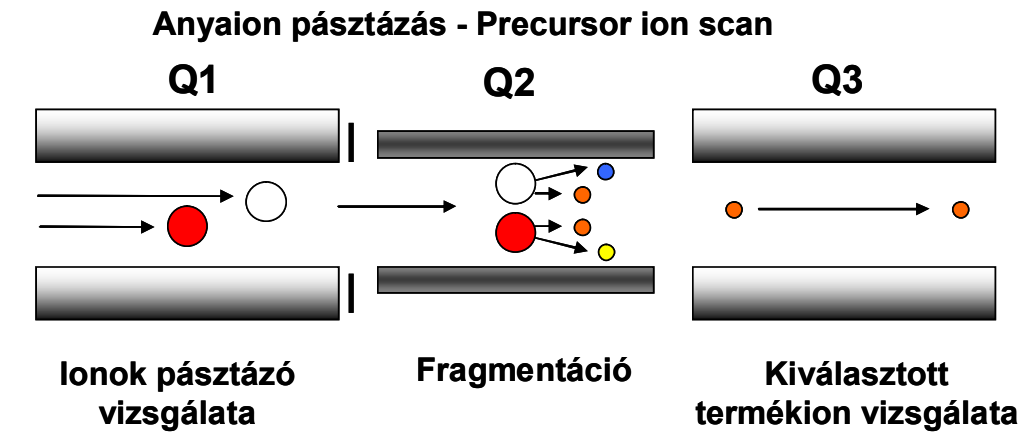

13. ábra: Az anyaion pásztázás sematikus bemutatása

A semleges vesztés (neutral loss scan) üzemmódban mindkét kvadrupól adott tömegtartományt pásztáz. A Q3 kvadrupól ugyanakkor a Q1-hez képest időben eltolva hajtja végre a pásztázási ciklusát. Az időbeli eltolás úgy van meghatározva, hogy a Q3 kvadrupól a vizsgálni kívánt semleges vesztésnek megfelelő tömeggel (pl. vízvesztés: -18 Da, glükóz leszakadás: -162 Da) késsen, lemaradjon a pásztázásban (14. ábra). Ezáltal a Q1 kvadrupólon átjutott ionok közül a Q3 kvadrupólon csak azok jutnak majd át, melyek a fregmentáció során az elöre meghatározott és beállított semleges vesztést szenvedik el. Így kimutathatók olyan folyamatok, melyek egy-egy semleges molekula kilépésével járnak.

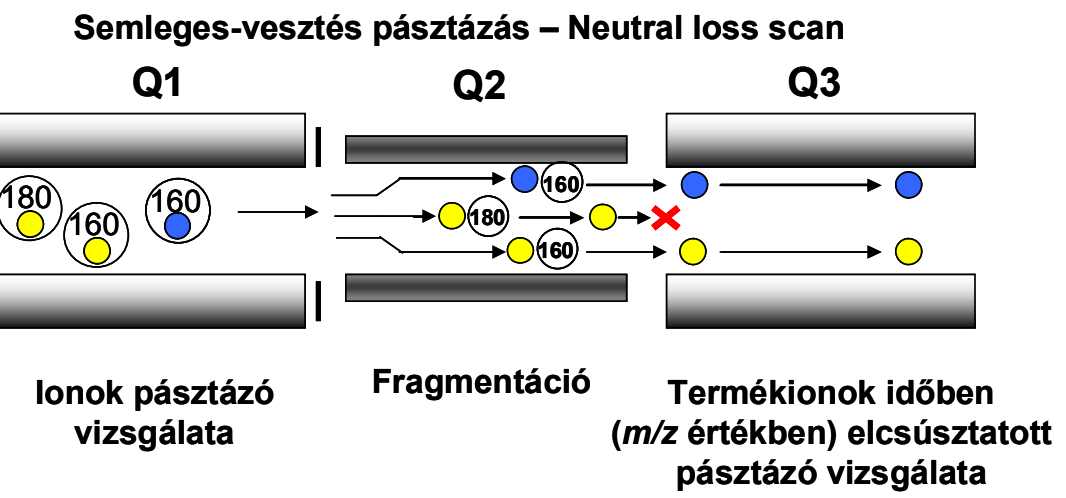

14. ábra: A semleges-vesztés pásztázás sematikus bemutatása

A legtöbbet használt beállítási mód a kiválasztott termékionok vizsgálata, (Multiple Reaction Monitoring, MRM, vagy Selected Reaction Monitoring, SRM) 
Ilyenkor a Q1 csak a meghatározott iont, a Q3 pedig csak az ehhez a prekurzorionhoz tartozó egy, vagy több (általában 2) kiválasztott fragmensiont enged át (15. ábra). Nagyfokú szelektivitásának és érzékenységének köszönhetően, kis koncentrációk kvantitatív mérésénél ez a legelterjedtebb módszer. Nagyfokú szelektivitása annak köszönhető, hogy míg az első Q1 kvadrupólba bejutott, adott tömegü ion - a kvadrupól egységnyi tömegfelbontásából adódóan akár többféle molekula is lehet, annak esélye jóval kisebb, hogy ugyanolyan prekurzor tömegü ionból azonos tömegü termékionok, azonos gyakorisággal fognak keletkezni. A pásztázási mód érzékenységét a szelektivitásból levezethető nagyon kedvező jel/zaj arány eredményezi.

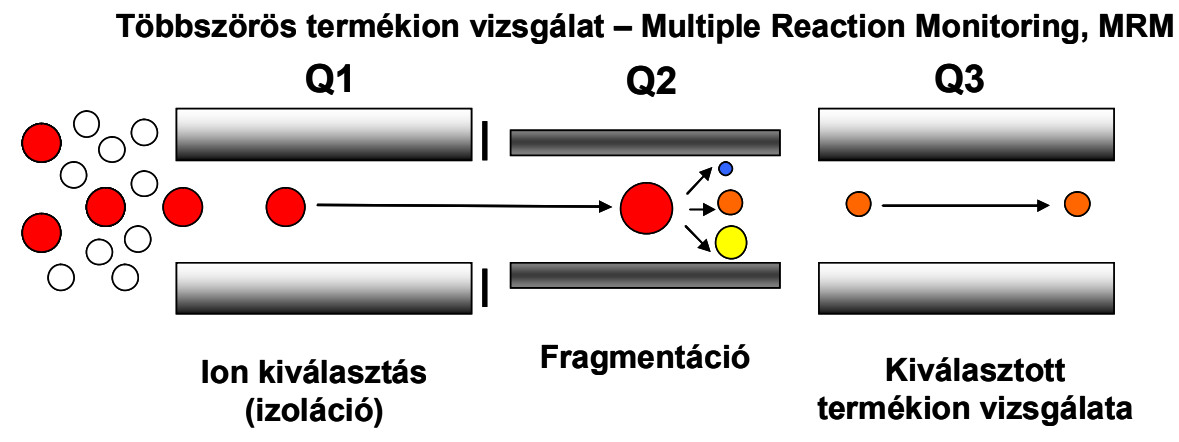

15. ábra: A többszörös termékion vizsgálat sematikus bemutatása

Ezen üzemódok hatékony müködéséhez szükséges paramétereket optimálni kell. Ezeket az optimált paramétereket a gyógynövények méréséhez használt módszerek esetében az 5.2. fejezetben mutatom be.

Az 5.3 fejezetben alkalmazott üzemmódok közül az MRM módszer esetében a következő beállításokat alkalmaztam: Ionforrás feszültség (IS): $5000 \mathrm{~V}$, szárító gáz hőmérséklet (TEM): $400{ }^{\circ} \mathrm{C}$, porlasztó és szárító gáz nyomása: 50 psi, klasztermentesítő potenciál (DP): $100 \mathrm{~V}$, belépési potenciál (EP): $10 \mathrm{~V}$, cella belépési potenciál (CEP): $15.02 \mathrm{~V}$, ütközési energia $(\mathrm{CE}): 50 \mathrm{~V}$, cella kilépő potenciál (CXP): $4 \mathrm{~V}$. Az anyaion pásztázás során a beállítások azonosak voltak, azzal a kivétellel, hogy a DP értékeket a szoftver automatikusan változtatta 40-80 V között az anyaion $m / z$ értékétől függően.

5.2-es fejezetben leírt vizsgálathoz használt tömegspektrometriás beállítások:

A repülési idő tömegspektrométer esetében beállított, optimált paraméterek a következök voltak: kapilláris feszültség: $\pm 2500 \mathrm{~V}$, porlasztó nyomás: 40 psi, szárító gáz $\left(\mathrm{N}_{2}\right)$ áramlási sebessége: 91 $\min ^{-1}$, gáz $\left(\mathrm{N}_{2}\right)$ hőmérséklet: $325{ }^{\circ} \mathrm{C}$, skimmer feszültség: $65 \mathrm{~V}$, fragmentor feszültség: $140 \mathrm{~V}$. A vizsgálathoz negatív ionmódba állítottam be a készüléket $\mathrm{m} / \mathrm{z}$ 50-1000 tömegtartományra. Az adatokat Agilent Mass Hunter szoftver segítségével dolgoztam fel (B.02.00 verzió, 2.0.197.0). A 
kiemelt ionkromatogram kinyeréséhez a pontosságot $\pm 5 \mathrm{mDa}$ tömegablakra állítottam be. A pontos tömeg méréséhez automata tömegkalibráló rendszer van beállítva, mely a tömegkorrekciót biztosítja. Ezt két elektroporlasztót magában foglaló ionforrás segítségével éri el, melyben az egyik (referencia) porlasztó a tömegkalibráló oldatokat alacsony áramlási sebességgel ( $\mathrm{kb} .10 \mu \mathrm{l} / \mathrm{min}$ ) juttatja az ionforrásba. A másik (analitikai) porlasztó pedig a folyadékkromatográfból érkező folyadékáramban lévő ionok ionforrásba juttatásáért felelős. A referenciaion pozitív ionmódban a purin $\left(\left[\mathrm{C}_{5} \mathrm{H}_{5} \mathrm{~N}_{4}\right]^{+}, m / z 121,050873\right)$ és a HP-0921 $\left(\left[\mathrm{C}_{18} \mathrm{H}_{19} \mathrm{O}_{6} \mathrm{~N}_{3} \mathrm{P}_{3} \mathrm{~F}_{24}\right]^{+}(m / z\right.$ 922,009798) protonált tömege volt, míg negatív ionmódban a trifluoroecetsav (TFA) anion $\left(\left[\mathrm{C}_{2} \mathrm{~F}_{3} \mathrm{O}_{2}\right]^{-}(\mathrm{m} / \mathrm{z} 112,985587)\right.$ és a HP-0921 TFA adduktja $\left(\left[\mathrm{C}_{20} \mathrm{H}_{18} \mathrm{O}_{8} \mathrm{~N}_{3} \mathrm{P}_{3} \mathrm{~F}_{27}\right]^{-}\right)(\mathrm{m} / z$ 1033,988109). 


\section{EREDMÉNYEK ÉS ÉRTÉKELÉSÜK}

\subsection{Gyógynövények fenolos komponenseinek vizsgálata}

A gyógynövények számos fontos élettani hatással rendelkeznek, melyek többek között olyan mikrokomponensekre vezethetők vissza, mint polifenolos vegyületek, ezen belül is a fenolos savak illetve a flavonoidok. A polifenolokhoz társított jótékony hatások helyes megítélésekor azonban mindig szem előtt kell tartani, hogy azok az alkotók melyekhez a hatást társítjuk, vajon valóban pontosan olyan formában vannak-e jelen a növényben, mint a jótékony hatás bizonyítása során alkalmazott forma. Ez a kérdés számos alkalommal merül fel olyankor, amikor a polifenolokat egyszerüsített analitikai módszerekkel vizsgálják. Ilyenkor ugyanis nem veszik figyelembe, hogy a mintában az adott hatóanyag esetleg valamilyen származék formájában van

jelen. Éppen ezért a kísérletek során olyan módszereket alkalmaztam, melyekkel vizsgálni tudtam a származék formában illetve szabadon előforduló legjellemzőbb fenolos savak arányát. Ebben a kísérletben kétfajta kerti kakukkfü illetve kétfajta szurokfü polifenolos alkotóit vizsgáltam. A kerti kakukkfüvekből (Thymus vulgaris L.) az úgynevezett „timolos”, azaz egy magas timol-tartalmú szelektált populációt illetve „nem timolos” azaz alfa-terpineol illetve alfa-terpinil-acetát kemotípusú populációt, a szurokfüvekből pedig görög (Origanum vulgare L. subsp. hirtum) és közönséges (Origanum vulgare L. subsp. vulgare) szelektált populációt vizsgáltam. A gyógynövényminták polifenol-összetevőinek vizsgálatát a bennük található fenolos savak mennyiségének vizsgálatával illetve a fellelhető flavonoidok feltérképezésével végeztem. Az OTKA által támogatott kísérletet a Gyógy- és Aromanövény Tanszékkel közösen végeztük.

\subsubsection{A gyógynövényekböl meghatározott fenolos savak bemutatása}

\subsection{1.a. Kakukkfü (Thymus vulgaris L.) fenolos savainak vizsgálati eredményei}

A fenolos savak esetében irodalmi adatok és előzetes kísérletek alapján a következő komponenseket vizsgáltam: p-kumársav, kávésav, ferulasav, sziringinsav, szinapinsav, klorogénsav, rozmaringsav. A komponensek szerkezeti képletei a 16. ábrán láthatóak. 

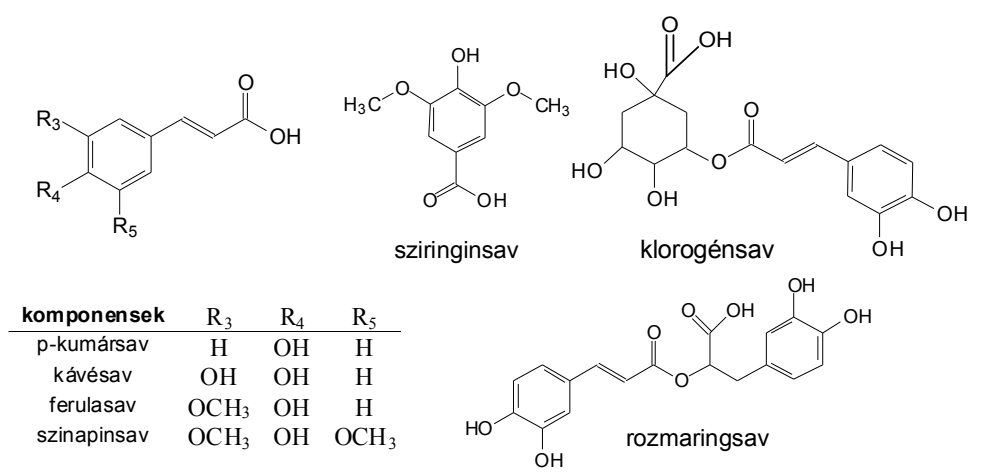

16. ábra: A vizsgált fenolos savak kémiai szerkezének bemutatása

Annak érdekében, hogy információt nyerhessünk a konjugált és nem konjugált fenolossav formák arányáról, a vizsgálatokat két különböző minta-előkészítéssel végeztem el. Az első mintaelőkészítés egy egyszerü vizes hígítás volt, a második típus egy lúgos hidrolízist tartalmazó lépést is magában foglalt. A célkomponensek tömegspektrometriás vizsgálatára leggyakrabban - így általam is - használt MRM pásztázást alkalmazó MS módszer sajátsága, hogy kizárólag az előre megadott komponensek iontömegeit méri. Ez azt jelenti, hogy így csak a vizsgálandó fenolos savak nem konjugált alapformáit látjuk, vagyis a nem hidrolizált extraktumból csak a természetes módon előforduló szabad (nem konjugált) formákat tudjuk detektálni.

Ugyanakkor, a hidrolizált extraktumban az összes konjugált és nem konjugált formában jelen lévő fenolos sav (melyek az eredeti extraktumban voltak) egyaránt nem konjugált formában lesz megtalálható. Ezt a megközelítést akkor célszerü alkalmazni, ha a származékként jelen lévő formák mennyiségére is kíváncsiak vagyunk, de nem rendelkezünk pontos információval arra vonatkozólag, hogy konkrétan milyen származékok vannak jelen a mintában (ebből adódóan azok várható iontömegeit sem tudjuk elöre). A módszer olyankor is használtható, ha minderről ugyan pontos információkkal rendelkezünk, de referenciaanyagok híján ezeket intakt formában nem tudjuk mennyiségileg meghatározni.

Az MS módszer kialakításának első lépése, a vizsgálandó molekulák nem konjugált formáira jellemző fragmensek meghatározása volt. A méréseket negatív módban végeztem és ezekhez kristályos referenciaanyagból készített standard oldatokat használtam. A felvett termékionspektrumok alapján minden komponens esetén kiválasztottam két jellemző és nagy gyakoriságú fragmenst és optimáltam a hozzájuk tartozó készülék-beállításokat. Ennek eredményeképpen a 2. táblázatban összefoglalt paramétereket kaptam. Ezek után a vizsgálatokat ezekkel a beállításokkal végeztem. 
2.táblázat: A fenolos savak vizsgálata során használt optimált paraméterek negatív ion módban. (Röviditések, mértékegységek: Komponensfüggö paraméterek: Deklaszter potenciál - DP (V), Belépési potenciál - EP (V), Ütközési cella belépö potenciál - CEP (V), Ütközési energia - CE (eV), Ütközési cella kilépési potenciál - CXP (V))

\begin{tabular}{|c|c|c|c|c|c|c|c|c|c|c|}
\hline \multirow{2}{*}{$\begin{array}{l}\text { Komponens } \\
\text { Kávésav }\end{array}$} & \multirow{2}{*}{$\begin{array}{c}\text { MT } \\
180\end{array}$} & \multirow{2}{*}{$\begin{array}{c}\begin{array}{c}\text { Prek. ion } \\
{[\mathrm{M}-\mathrm{H}]^{-}}\end{array} \\
179\end{array}$} & \multicolumn{2}{|c|}{ Fragmensek } & \multirow{2}{*}{$\begin{array}{c}\mathrm{DP} \\
-40\end{array}$} & \multirow{2}{*}{$\frac{E P}{-6}$} & \multirow{2}{*}{$\begin{array}{c}\text { CEP } \\
-10\end{array}$} & \multirow{2}{*}{$\begin{array}{c}\text { CE1 } \\
-20\end{array}$} & \multirow{2}{*}{$\frac{\text { CE2 }}{-32}$} & \multirow{2}{*}{$\frac{\mathrm{CXP}}{0}$} \\
\hline & & & 135 & 107 & & & & & & \\
\hline Klorogénsav & 354 & 353 & 191 & 127 & -40 & -6 & -16 & -22 & -50 & 0 \\
\hline Ferulasav & 194 & 193 & 134 & 178 & -40 & -5 & -44 & -22 & -8 & $0 ;-4$ \\
\hline p-kumársav & 164 & 163 & 119 & 117 & -35 & -3 & -12 & -24 & -44 & 0 \\
\hline Rozmaringsav & 360 & 359 & 161 & 197 & -50 & -8 & -14 & -26 & -26 & 0 \\
\hline Szinapinsav & 224 & 223 & 164 & 208 & -55 & -6 & -14 & -22 & -20 & 0 \\
\hline Sziringinsav & 198 & 197 & 121 & 182 & -20 & -12 & -12 & -26 & -22 & 0 \\
\hline \multicolumn{11}{|c|}{ lonforrás paraméterek } \\
\hline Ionforrás feszült & \multicolumn{4}{|c|}{$-4500 \mathrm{~V}$} & & & & & & \\
\hline Ionforrás hőmér & \multicolumn{4}{|c|}{$350^{\circ} \mathrm{C}$} & & & & & & \\
\hline \multicolumn{2}{|c|}{ Szárító $\left(\mathrm{N}_{2}\right)$ és porlasztógáz $\left(\mathrm{N}_{2}\right)$ nyomása: } & $40 \mathrm{ps}$ & & & & & & & & \\
\hline
\end{tabular}

Az optimálást követően a megfelelő kromatográfiás elválasztást alakítottam ki standard oldatokkal. Egy jellegzetes standard kromatogramot mutat az 17. ábra.

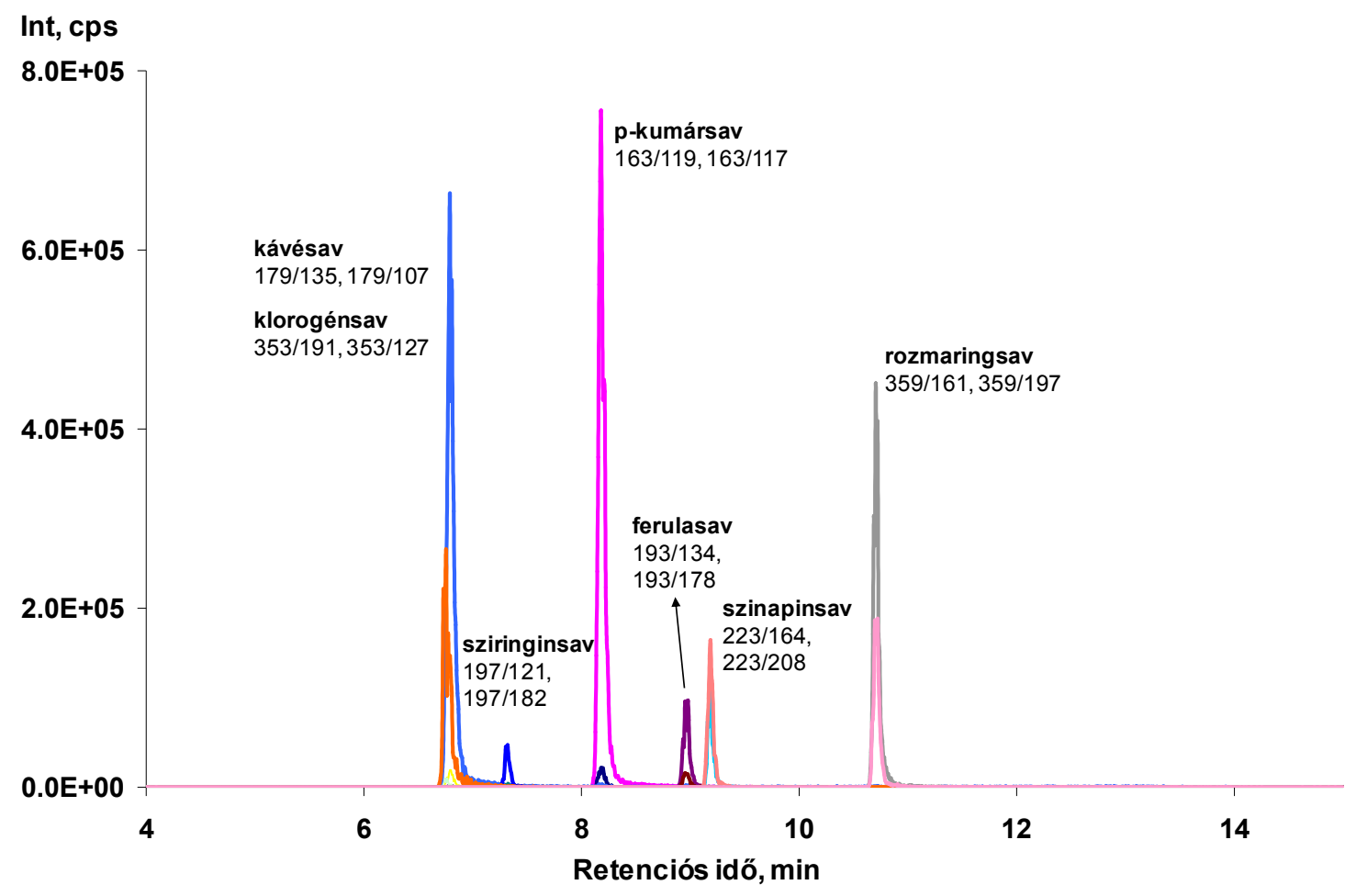

17. ábra: Fenolos savak standard kromatogramja (koncentráció: $4 \mu \mathrm{g} / \mathrm{ml}$ ) 
A két minta-előkészítést követően, a mintákat MRM pásztázást alkalmazó MS módszerrel mértem meg. Ennek eredményeit a következőkben mutatom be. Elsőként a kakukkfüben talált fenolos savak mennyiségi vizsgálatának eredményeiről írok, ezen belül is a „nem timolos” típusú mintáról. A kapott eredményeket a 18. ábrán szemléltettem. A „nem timolos” kakukkfü vizes extraktumaiban a hét vizsgált fenolos sav közül 6 volt megtalálható, melyek közül a rozmaringsav volt jelen a legnagyobb mennyiségben. Ennek koncentrációja (881,5 $\mu \mathrm{g} / \mathrm{g}$ friss tömeg) kb. negyvenszerese volt a kávésavénak (14,13 $\mu \mathrm{g} / \mathrm{g}$ friss tömeg), mely a második legnagyobb koncentrációban jelen lévő fenolos sav volt a mintában. Ezt követte a klorogénsav 5,03 $\mu \mathrm{g} / \mathrm{g}$ friss tömegre vonatkoztatott koncentrációval. A további három meghatározott komponens, a p-kumársav $(0,98 \mu \mathrm{g} / \mathrm{g}$ friss tömeg), a ferulasav ( $1,08 \mu \mathrm{g} / \mathrm{g}$ friss tömeg) illetve a sziringinsav $(0,98 \mu \mathrm{g} / \mathrm{g}$ friss tömeg) volt.

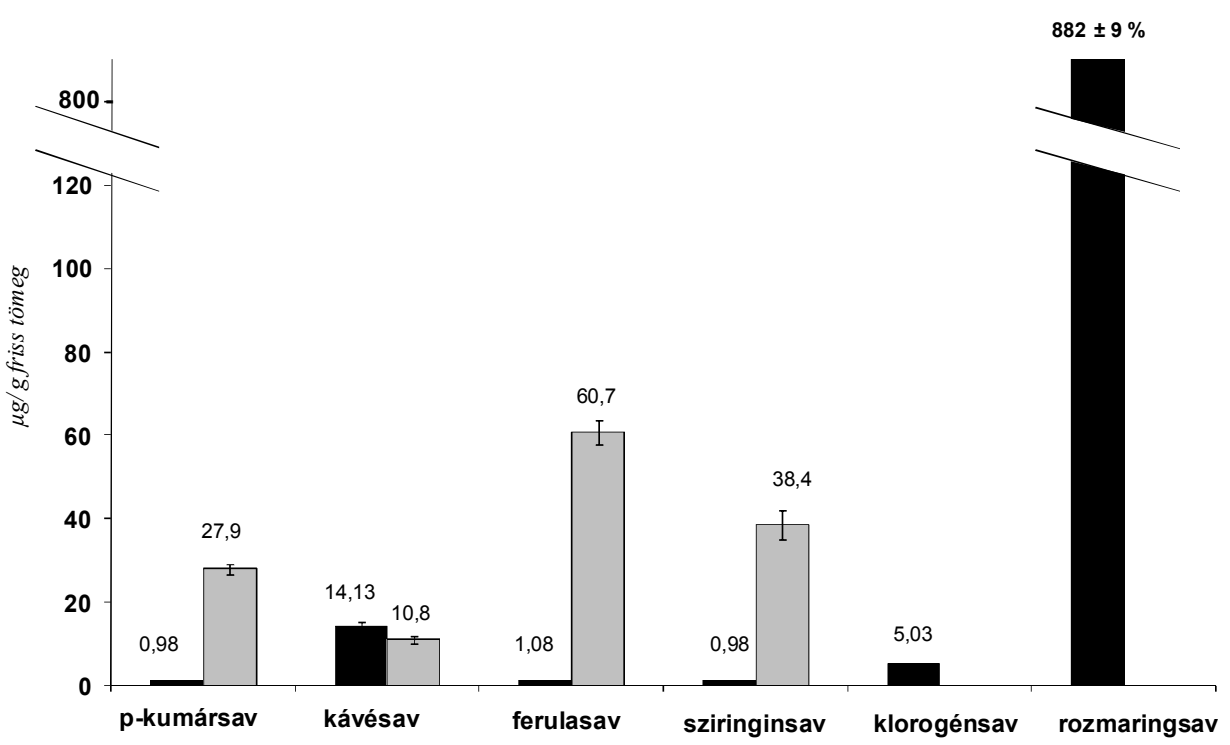

18. ábra: A vizsgált fenolos savak mennyisége a „nem timolos” típusú minták vizes extraktumaiban (fekete oszlopok) illetve lúgos hidrolizissel elökészitett (szürke oszlopok) vizes extraktumok esetén ( $n=2)$

A hidrolizált minta-előkészítést követően a vizsgált hét fenolos savból csak négyet találtam a „nem timolos” kakukkfü mintában. A vizes extraktumban nagyon nagy koncentrációban jelen lévő rozmaringsav teljesen eltünt a klorogénsavval együtt, viszont jelentősen megnőtt a kis koncentrációban jelen lévő komponensek mennyisége. A hidrolizált mintában legnagyobb koncentrációban a ferulasav volt jelen $(60,7 \mu \mathrm{g} / \mathrm{g}$ friss tömeg), mely kb a hatvanszorosa a nem hidrolizált extraktumban mért koncentrációnak. A következő a sziringinsav volt, mely 38,4 $\mu \mathrm{g} / \mathrm{g}$ friss tömeg koncentrációban volt jelen. Ez majdnem negyvenszeres koncentrációnövekedés a nem hidrolizált extraktumhoz képest. A p-kumársavból 27,9 $\mu \mathrm{g} / \mathrm{g}$ friss tömeg koncentrációt mértem, 
mely majdnem harmincszorosa a nem hidrolizált extraktumban mért koncentrációnak. A negyedik fenolos sav a kávésav volt, melynek koncentrációja nem változott jelentősen, 10,8 $\mu \mathrm{g} / \mathrm{g}$ friss tömeg mennyiségben volt jelen. Összességében megállapítható, hogy a vizes extraktumban kis koncentrációban jelen lévő komponensek mennyisége a hidrolizált minta-előkészítést követően megnőtt, míg a nem hidrolizált extraktumban nagy koncentrációban előforduló komponensek (azaz a rozmaringsav és a klorogénsav) - a kávésav kivételével - a hidrolizált mintában nem voltak detektálhatóak.

A „timolos” kemotípusú kakukkfüvek mérési eredményei (19. ábra) azt mutatták, hogy a nem hidrolizált extraktumban megintcsak a rozmaringsav volt a legnagyobb mennyiségben előforduló fenolos sav, mely 1677,3 $\mu \mathrm{g} / \mathrm{g}$ friss tömegre vetített koncentrációt jelentett. Ez kétszer annyi, mint amennyi a „nem timolos” típusú kakukkfü mintában volt jelen. Ennél a mintánál a klorogénsav koncentrációja fele akkora $(2,8 \mu \mathrm{g} / \mathrm{g}$ friss tömeg), míg a kávésav, bár nem jelentős mennyiséggel, de nagyobb (18,9 $\mu \mathrm{g} / \mathrm{g}$ friss tömeg) koncentrációban volt jelen, mint a „nem timolos" kemotípusú minta, nem hidrolizált extraktumában. A kis mennyiségben jelen lévő komponensek közül a ferulasav hasonló koncentrációt mutatott $(1,8 \mu \mathrm{g} / \mathrm{g}$ friss tömeg), a sziringinsav kétszer akkora $(2,6 \mu \mathrm{g} / \mathrm{g}$ friss tömeg), míg a p-kumársav fele akkora $(0,4 \mu \mathrm{g} / \mathrm{g}$ friss tömeg) koncentrációban volt jelen, mint az azonos minta-előkészítésen átesett „,nem timolos” kakukkfü.

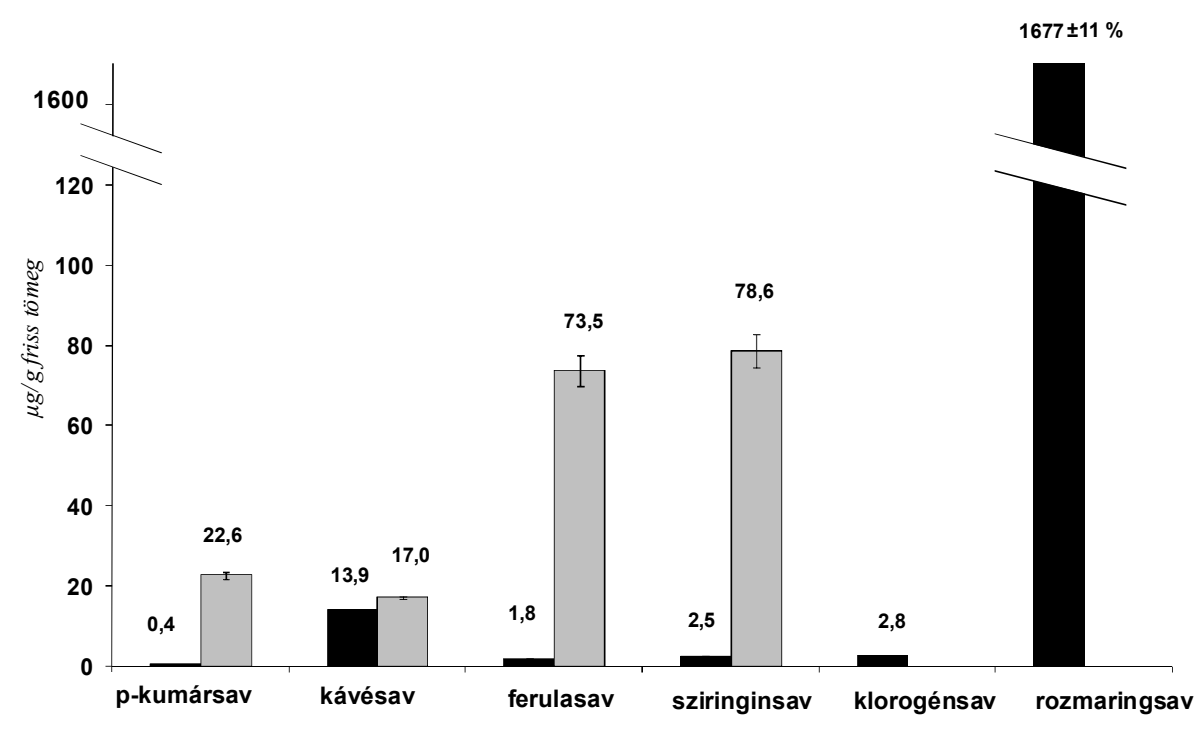

19. ábra: A vizsgált fenolos savak mennyisége a „timolos" típusú minták vizes extraktumaiban (fekete oszlopok) illetve lúgos hidrolizissel elökészitett (szürke oszlopok) vizes extraktumok esetén (n=2) 
A hidrolizált minta-előkészítéssel kinyert fenolos savak a „timolos” kakukkfü esetében hasonlóan viselkedtek, mint a „,nem timolos” mintánál. A vizsgált hét komponens közül itt is csak 6 volt megtalálható. Különbség volt azonban, hogy ennél a mintánál a sziringinsav volt jelen a legnagyobb koncentrációban (78,6 $\mu \mathrm{g} / \mathrm{g}$ friss tömeg), mely harmincszorosa a nem hidrolizált extrumban mért, és kétszerese a „nem timolos” kakukkfü minta hidrolizált extraktumában mért koncentrációnak. Ezt követte a ferulasav 73,5 $\mu \mathrm{g} / \mathrm{g}$ friss tömeg koncentrációval, mely negyvenszeres koncentrációemelkedést mutat a nem hidrolizált extraktummal összehasonlítva. A „,nem timolos” kakukkfü mintához képest nagyobb koncentrációban volt jelen. A p-kumársav szintén hasonló koncentrációban volt jelen, $22,6 \mu \mathrm{g} / \mathrm{g}$ friss tömeg mennyiségben, mely 56 -szorosa a nem hidrolizált extraktumban mért mennyiségnek. A kávésav mennyisége a hidrolizáció hatására ebben a mintában, bár nem jelentős mértékben, de megnőtt 17,0 $\mu \mathrm{g} / \mathrm{g}$ friss tömeg koncentrációra.

Tehát a két mintáról összességében elmondható, hogy a vizsgált fenolos savak között - az irodalmi adatoknak megfelelően - a rozmaringsav volt a fő komponens mindkét („timolos” és „nem timolos") kemotípus esetében, de a kávésav, klorogénsav, p-kumársav, ferulasav és sziringinsav is jelentős mennyiségben volt jelen.

Mindkét mintánál megfigyelhető volt a hidrolizált minta-előkészítést követően, bizonyos komponensek koncentrációjának ugrásszerü növekedése. A nem hidrolizált extraktum lúgos hidrolízisét követő vizsgálat után megállapítható volt, hogy ezek a ferulasav, a sziringinsav és a pkumársav voltak, növekedésükre a magyarázat pedig az, hogy ezek jelentős részre a vizes extraktumban konjugált formában volt jelen. A hidrolizált mintákban a ferulasav és a sziringinsav volt a fö komponens, de p-kumársav, kávésav is jelentős mennyiségben volt jelen. Továbbá elmondható hogy a „timolos” mintákban a sziringinsav és rozmaringsav jelentősen nagyobb mennyiségben fordult elö, mint a „nem timolos” típusban (lásd Melléklet 2.).

Szinapinsavat sem konjugált, sem szabad formában nem találtam a mintákban. Ahogy az a 18-19. ábrákon látható, a rozmaringsav és klorogénsav a lúgos hidrolízist követően nem volt kimutatható a mintából. Ez a jelenség ezen észter típusú molekuláknak a lúgos hídrolízis hatására történő lebomlásával magyarázható. A klorogénsav kínasavvá, és kávésavvá, míg a rozmaringsav 3,4-dihidroxi-feniltejsav-észterré és kávésavvá bomlik (20. ábra). 


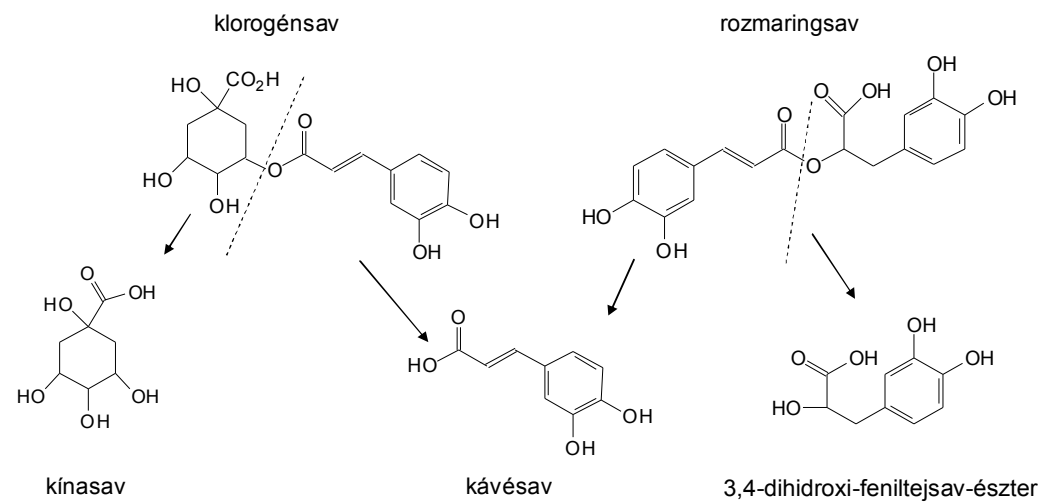

20. ábra: A klorogénsav és rozmaringsav lúgos hidrolizis hatására történö degradációjának bemutatása

Ennek megfelelően a kávésavnak meg kellett volna jelennie a hidrolizált mintaelőkészítésen átesett extraktumokban, de ennek mennyisége mindkét minta-előkészítést követően szinte azonos volt. Ez azt jelenti, hogy a két komponens degradációjakor keletkezett kávésav tovább bomlott a lúgos környezetben. Ez a jelenség a rozmaringsav és klorogénsav standardokkal is megerősítésre került. Eredményeinkhez hasonló eredményeket kaptak más tanulmányokban is [MAILLARD \& BERSET, 1995; KRYGIER et al., 1982]. Például Krygier és munkatársai a kísérleteikről szóló cikkben 67\%-os kávésav veszteséget publikáltak. Azonban ugyanabban a tanulmányban azt is megállapították, hogy a hidroxi-fahéjsavak egy részénél a veszteség maximum $10 \%$ volt az eredeti értékekhez képest (o-kumár-, p-kumár-, izoferula- és ferulasavak esetében; $4 \mathrm{~N}$ $\mathrm{NaOH}$-dal, 4 h nitrogén alatt) [KRYGIER et al., 1982]. Ezek a megállapítások összhangban vannak a mi eredményeinkkel a vizsgált fenolos savak esetében a hidrolizált minta-előkészítés után.

\subsection{1.b. Szurokfü (Origanum vulgare L.) fenolos savainak vizsgálati eredményei}

Szurokfüvek esetében is megvizsgáltuk a fenolos savas komponenseket mindkét mintaelökészítéssel. Két típust vizsgáltunk, görög oregánó (Origanum vulgare L. subsp. hirtum), illetve közönséges szurokfü (Origanum vulgare L. subsp. vulgare) mintákat. Minden esetben $40{ }^{\circ} \mathrm{C}$-on szárított mintákkal dolgoztunk. A populációkból és a minta-előkészítésekből adódó különbségek eredményét a következőkben mutatom be.

A görög oregánó vizsgálatának eredményeit a 21. ábra foglalja össze. A nem hidrolizált vizes extraktum vizsgálatakor a hét vizsgált fenolos sav közül öt komponens volt megtalálható, szinapinsav és sziringinsav nem volt kimutatható. Az eredmények vizsgálatakor azt láthatjuk, hogy a mért komponensek közül ismét a rozmaringsav volt jelen a legnagyobb mennyiségben $(1243,1$ $\mu \mathrm{g} / \mathrm{g}$ friss tömeg). Ezt követte a kávésav 102,0 $\mu \mathrm{g} / \mathrm{g}$ és a klorogénsav 80,0 $\mu \mathrm{g} / \mathrm{g}$ friss tömeg 
értékekkel. Ezen kívül p-kumársav és ferulasav is jelen volt a mintában, de csak kis mennyiségben $(12,4$ illetve 5,4 $\mu \mathrm{g} / \mathrm{g}$ friss tömeg), mely a kakukkfüveknél is hasonló tendenciát mutatott.

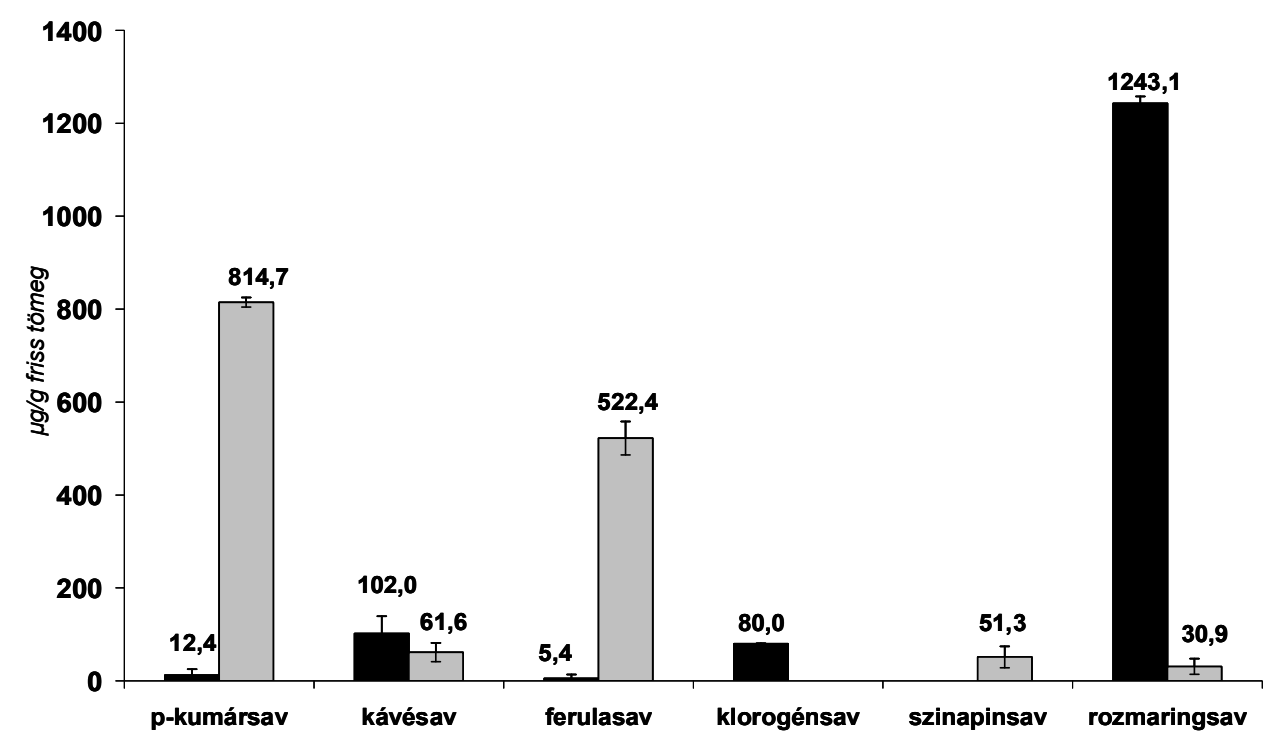

21. ábra: A vizsgált fenolos savak mennyisége $40{ }^{\circ} \mathrm{C}$-on száritott görög oregánó minták vizes extraktumaiban (fekete oszlopok) illetve lúgos hidrolizissel elökészitett (szürke oszlopok) vizes extraktumok esetén $(n=2)$

A lúgos hidrolízissel elökészített vizes extraktumok estében ugyan ennél a növénynél ismét megfigyelhető a kakukkfüveknél már említett jelenség, azaz, hogy a p-kumársav és a ferulasav mennyisége sokszorosára nő a vizes extraktumban kapott értékekhez képest. Azonban e minta esetében a hidrolizált minta-előkészítést követően a p-kumársav volt jelen a legnagyobb koncentrációban $(814,7 \mu \mathrm{g} / \mathrm{g}$ friss tömeg) és csak ezt követte a ferulasav 522,4 $\mu \mathrm{g} / \mathrm{g}$ friss tömeg koncentrációval. Ez a p-kumársav esetében 60-szoros, míg a ferulasav esetében 100-szoros koncentrációemelkedést jelent a minta vizes oldatához képest. Ezeken a komponenseken kívül megjelenik a szinapinsav (51,3 $\mu \mathrm{g} / \mathrm{g}$ friss tömeg) is, mely a kakukkfünél nem volt detektálható. Azonban a klorogénsav teljesen elhidrolizálódik, a rozmaringsav pedig jelentős mértékben lecsökken 30,9 $\mu \mathrm{g} / \mathrm{g}$ friss tömeg koncentrációra, mely 75\%- os veszteség. A kávésav mennyisége csakúgy, mint a kakukkfünél - szignifikáns változást nem mutatott, $61,6 \mu \mathrm{g} / \mathrm{g}$ friss tömeg koncentrációban volt jelen.

A $40{ }^{\circ} \mathrm{C}$-on szárított közönséges szurokfü minták eredményei a 22. ábrán láthatóak. A hidrolízis nélküli vizes oldatban ismét a rozmaringsav volt jelen kiemelkedő mennyiségben (1375,6 $\mu \mathrm{g} / \mathrm{g}$ friss tömeg), azonban a többi komponens közül csak a kávésav mutatott magasabb értékeket 
$(82,0 \mu \mathrm{g} / \mathrm{g}$ friss tömeg). Míg a görög oregánó vizes extraktumában jelentős mennyiségben volt megtalálható a klorogénsav, itt csak viszonylag kis mennységben $(16,0 \mu \mathrm{g} / \mathrm{g}$ friss tömeg) volt jelen. A p-kumársav (15,8 $\mu \mathrm{g} / \mathrm{g}$ friss tömeg) és a ferulasav (3,2 $\mu \mathrm{g} / \mathrm{g}$ friss tömeg) a görög oregánóhoz hasonlóan csak, alacsony koncentrációban volt kimutatható a mintában.

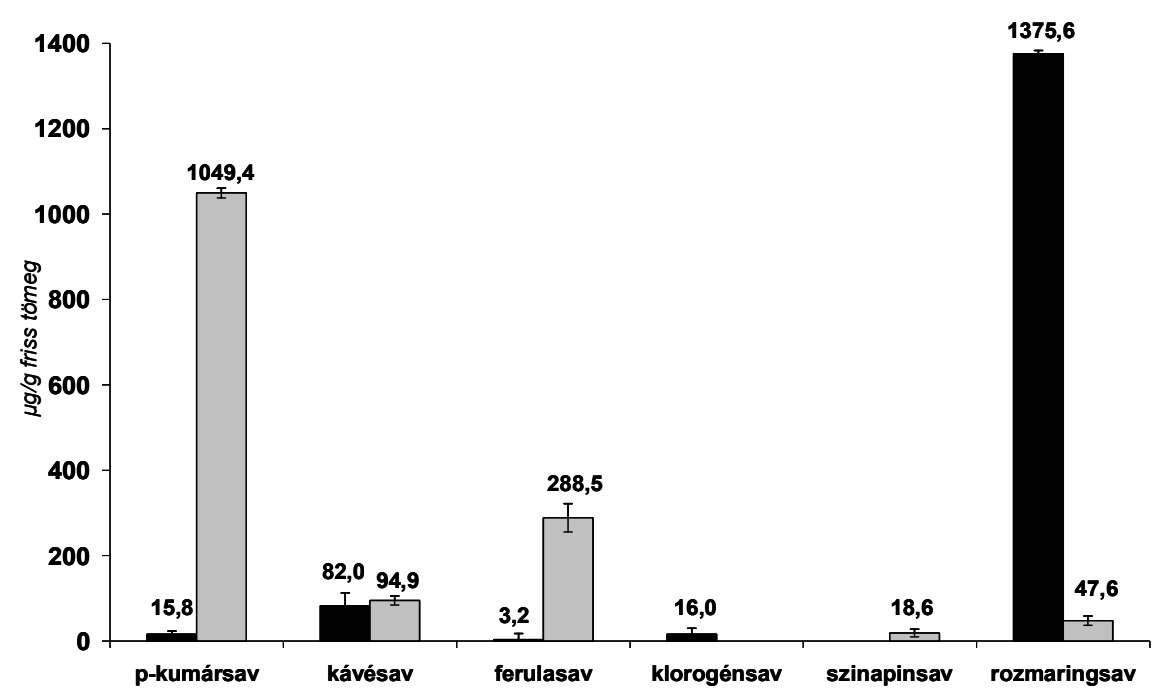

22. ábra: A vizsgált fenolos savak mennyisége $40{ }^{\circ} \mathrm{C}$-on száritott közönséges szurokfü minták vizes extraktumaiban (fekete oszlopok) illetve lúgos hidrolizissel elökészitett (szürke oszlopok) vizes extraktumok esetén $(n=2)$

A lúgos hidrolízist követő mérési eredmények a görög oregánónál megfigyelt eredményekhez hasonlóan alakultak. Ahogy azt várhattuk, a p-kumársav mennyisége a 70szeresére nőtt (1049,4 $\mu \mathrm{g} / \mathrm{g}$ friss tömeg) és ez volt a fö komponens, melyet a ferulasav követett, melynek mennyisége kb. 90-szeresére növekedett (288,5 $\mu \mathrm{g} / \mathrm{g}$ friss tömeg). A szinapinsav ebben a mintában is megjelent $18,6 \mu \mathrm{g} / \mathrm{g}$ friss tömeg koncentrációban, míg a rozmaringsav $47,6 \mu \mathrm{g} / \mathrm{g}$ friss tömegre csökkent, mely kb 30-szoros veszteséget jelent, a klorogénsav pedig teljesen elhidrolizált. A kávésav itt sem mutatott nagyobb változást, 94,9 $\mu \mathrm{g} / \mathrm{g}$ friss tömeg koncentráció volt mérhető a mintában.

A két oregánó típust összehasonlítva megállapíthatjuk, hogy a rozmaringsav és a kávésav mindkettőben közel azonos mennyiségben volt jelen, míg a klorogénsav a görög oregánó mintában ötször nagyobb koncentrációt mutatott, mint a közönséges szurokfüben. Az egyes komponensek hidrolizált minta-előkészítést követő növekedése illetve a szinapinsav megjelenése itt is arra utal, hogy ezek egy része konjugált formában volt jelen a mintában. A hidrolizációs minta-előkészítés után kapott eredmények alapján elmondható, hogy mindkét mintában közel azonos mennyiségü p- 
kumársavat lehetett meghatározni, azonban a görög oregánó majdnem kétszer annyi ferulasavat és háromszor annyi szinapinsavat tartalmazott, mint a közönséges szurokfü (lásd Melléklet 2.).

A kakukkfü és szurokfü mintákat összehasonlítva azt láthatjuk, hogy mindkét gyógynövényben, kemotípustól függetlenül a rozmaringsav volt a legjellemzőbb fenolos sav és mindkettőben megközelítőleg hasonló koncentrációban volt jelen. Ugyanez elmondható a vizes extrahálással kinyert, szabad formában lévő p-kumársav, kávésav és ferulasav esetében is. A klorogénsav és a kávésav koncentrációja viszont a szurokfüvekben komponenstől és populációtól függően 4-16-szor nagyobb volt, mint a közönséges kakukkfüvekben. A vizes extraktumban kötött formában jelen lévő, lúgos hidrolízissel felszabadult komponensek esetében viszont az látható, hogy mind a közönséges, mind a görög oregánó ezekből az alkotókból, komponenstől függően, 230-szor nagyobb mennyiségekkel rendelkezett a kakukkfüvekhez képest. Ezen kívül az is látszik, hogy míg a kakukkfüben a ferulasav és a sziringinsav volt jelen nagyobb mennyiségben, addig az oregánónál a p-kumársav és a ferulasav volt a két fő komponens. További érdekesség, hogy míg a kakukkfüvekben a sziringinsav jelent meg a hidrolízis hatására, és szinapinsav egyáltalán nem volt detektálható, addig a szurokfüveknél ez pont fordítva volt, sziringinsav nem volt jelen a mintában, de a hidrolizált mintában megjelent a szinapinsav.

Tehát sikerült hazai termesztésű görög illetve közönséges szurokfüvek, továbbá „timolos” illetve „nem timolos” kakukkfüvek fontosabb fenolos sav készletének összehasonlítását elvégezni. A vizsgálat különlegessége volt, hogy a pontosabb meghatározás és az eredeti fenolos sav készlet jobb feltárása érdekében nem csak vizes extrakciót, de lúgos hidrolízist is használtam. A mintaelőkészítést követően HPLC-MS/MS müszerkapcsolással, MRM módszerrel mértem meg a mintákat. Az eredmények azt mutatták, hogy a lúgos hidrolizációs minta-előkészítés valóban szükséges, hiszen ez után a minta-elökészítés után komponenstöl függően 20-100-szoros koncentráció-növekedés is megfigyelhető volt. A vizsgált gyógynövényekben az irodalomnak megfelelően a rozmaringsav volt jelen a legnagyobb koncentrációban. Azonban a ferulasav és a pkumársav illetve a kakukkfü esetében a sziringinsav is jelentős mennyiségben fordult elő. Végül elmondhatjuk, hogy az eredmények jól tükrözik azt az elméletet, hogy ahhoz, hogy teljesebb képet kapjunk a mintában jelen lévő polifenolos komponensekről, nem elegendő egyszerü vizes kioldást használnunk amennyiben célkomponens kereső módszerrel mérünk. Szükség van egy hirolizációs előkészítésre is, hogy a konjugátumoktól felszabadult aglikonokat is láthatóvá tegyük a módszerünk számára. Tehát a két minta-előkészítés egyike sem ad helyes eredményt a másik nélkül, így együtt alkotnak komplex és a valóságnak megfelelő képet a mintáról. 


\subsubsection{A kakukkfüböl és szurokfüböl meghatározott flavonoidok bemutatása}

A fenolos savak vizsgálata mellett kíváncsi voltam arra is, hogy milyen flavonoid molekulák lehetnek jelen ezekben a gyógynövényekben. Azonban nem az aglikonokat (a flavonoid alapmolekulákat) szerettem volna mérni, hanem a flavonoidok esetében is feltérképzeni azokat az eredeti, konjugált formákat, amelyek a növényben előfordulnak. A fenolos savak vizsgálata során alkalmazott módszer a konjugált/szabad formák arányára vonatkozóan, a minta-előkészítés során alkalmazott lúgos hidrolízist felhasználva tudott választ adni. Arról azonban ez a megközelítés nem nyújtott információt, hogy a konjugált formák esetében valójában milyen molekularészletek konjugálódtak az alapmolekulákhoz? A flavonoidok feltérképezése során ezért egy másik megközelítést alkalmaztam. A tömegspektrometriás módszerben rejlő lehetőségeket kihasználva kívántam választ kapni arra, hogy a konjugált ún. glikán részek minőségéről is információhoz jussak. Tehát e módszer előnye a fenolsavak vizsgálatához alkalmazottal szemben, hogy alkalmazásával információt kapunk arra vonatkozólag, hogy az adott flavonoidok vajon milyen származékok formájában vannak jelen az extraktumban. Ugyanakkor e módszer nem alkalmas arra, hogy a származékok mennyiségéről információt nyújtson. Ez utóbbi oka, hogy a származékokat intakt formában vizsgáljuk és így mennyiségi meghatározásukhoz referencia anyagra volna szükség, ami sok esetben kereskedelemben nem beszerezhető. Ehhez a vizsgálathoz szintén HPLCESI-MS/MS módszert alkalmaztam, de nem az előző kísérletnél használt célkomponensek vizsgálatára kifejlesztett MRM módszert, hanem egy korábban már gyümölcslé mintán kipróbált olyan három lépcsős kereső módszert (23. ábra), melynek segítségével mérhetővé válnak a vizsgált gyógynövényekben esetleg jelen lévő flavonoid-származékok [RAK et al., 2010].

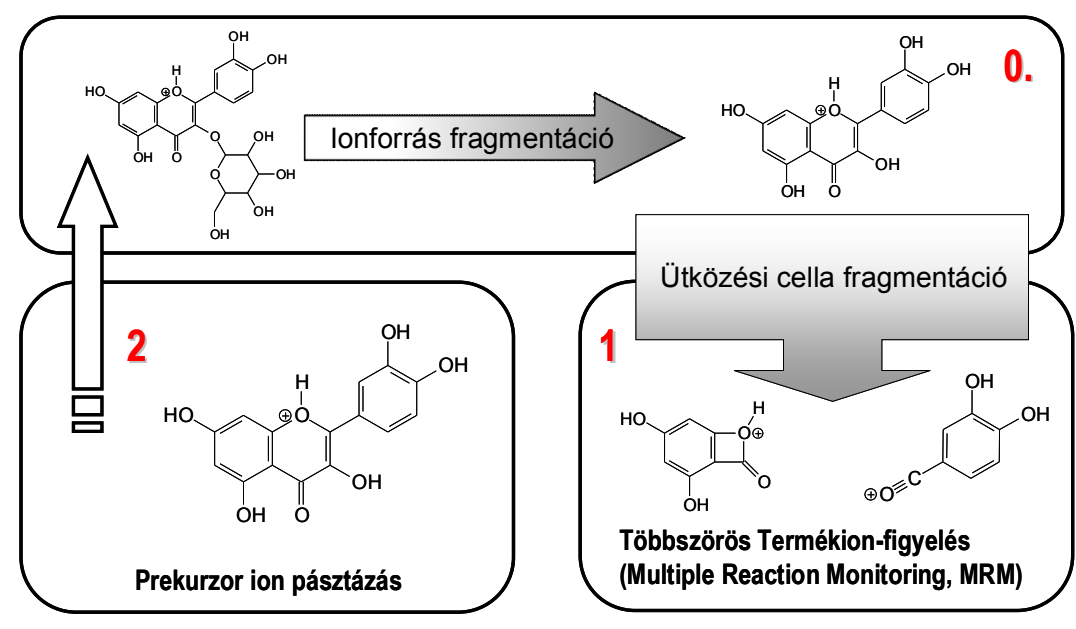

23. ábra: A háromlépéses kereső módszer felépitésének bemutatása 
Az MS screening módszer két ún. tömegspektrometriás kísérletből állt, melyek a kromatográfiás futás során egymást ciklikusan ismétlődve követték. Az első a már előző fejezetben is tárgyalt, többszörös temékion vizsgálat (multiple reaction monitoring, MRM). Itt két karakterisztikus fragmens kiválasztásával az aglikon minőségi azonosítását nagyfokú szelektivitással tudjuk elvégezni, de csak akkor, ha az adott aglikon (ion) önmagában (azaz nem származékként) van jelen. Mivel arra számítunk, hogy az extraktumban a vizsgált aglikonoknak különböző konjugátumai is jelen lesznek, ezért első lépésben ezekből az aglikon részt kell felszabadítani. Ahhoz tehát, hogy az MRM módszerhez „bemeneti” jelet képezzünk, a flavonoid származék aglikon részét olyan független alegységként kell fragmentációval előállítani melynek iontömege az MRM módszerben prekurzorion-tömegként van beállítva. Az előző módszerben ennek érdekében használtuk a lúgos hidrolizációs minta-előkészítést, azonban egy ilyen eljárás után az eredeti komponensek meghatározása már nem lehetséges. Tehát egy olyan eljárást kell alkalmazni, melynek során a mintában lévő komponens nem változik, mégis a műszerbe való bekerülés során leszakad az aglikonról a konjugátum és mérhetővé válik az aglikon. Ennek érdekében az egyes származékokból ionforrás fragmentációval állítottam elő az aglikon alegységeket. Ezt a folyamatot a 24. ábra szemlélteti. Ennek eredményeként, ha az extraktumban jelen volt egy adott aglikon valamilyen konjugátuma, akkor az ionforrásban történő fragmentáció során az aglikon egység lehasadva, az MRM módszerrel szelektíven azonosíthatóvá válik [RAK et al., 2010; ABRANKO et al., 2011].

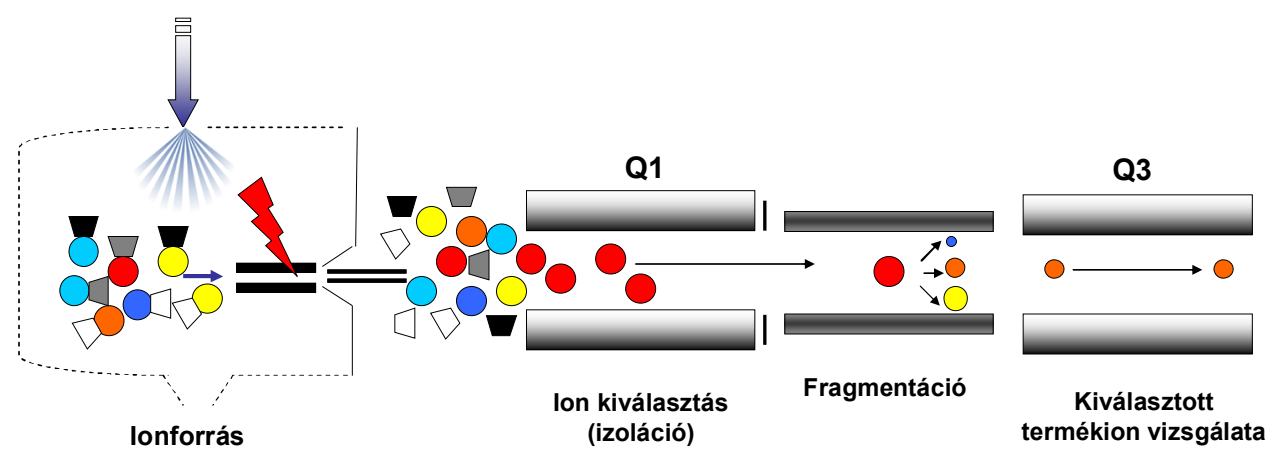

24. ábra: Az ionforrás fragmentáció müködésének bemutatása

Ezt úgy lehet elérni, hogy a beállítási paraméterek között szereplő úgynevezett klasztermentesítő potenciált (továbbiakban az angol 'declustering potential' megfelelője alapján DP) a szokásos értékeknél nagyobbra állítjuk, így elérhető, hogy az aglikon leszakadjon az intakt molekuláról. Az irodalomból ismert jelenség, hogy ilyenkor a glikán rész lehasadása után keletkező aglikon fragmens ugyanolyan iontömegü, mintha az a szabad aglikonból képződött volna protonálódással vagy deprotonálódással [VUKICS \& GUTTMAN, 2010]. Többfajta flavonoid 
származék és egyfajta aglikon-molekulának több származéka is várható egy mintából, ezért kompromisszumos ionforrás beállítások alkalmazására van szükség. A korábbi optimálások eredményeire alapozva a választott érték $-120 \mathrm{~V}$ lett, mely az MRM módszerben volt beállítva [RAK et al., 2010]. Ezzel a módszerrel 10 aglikont vizsgáltam (apigenin, luteolin, miricetin, naringenin, kvercetin, heszperetin, fiszetin, daidzein, genisztein, kaempferol) melyek közül a mintákban három aglikon jelenlétét igazoltam. A kakukkfü esetében naringenint, luteolint és apigenint, míg a szurokfü esetében luteolint és apigenint (és ezek származékait) lehetett megtalálni.

Tehát az első lépés után meg lehet állapítani, mely aglikonok származékai találhatóak a mintában, de további információt nem szolgáltat róluk. Így a következő lépésben végrehajtott MS kísérletben arra kaphatunk választ, hogy az adott aglikon milyen konjugátum formákban van jelen az extraktumban. Ezt prekurzorion pásztázási módszerrel lehet elérni, mellyel azt vizsgáljuk, hogy az aglikon alegységnek megfelelő ion milyen eredeti tömegü ionból származik. A módszer részletes bemutatását a 4.6. fejezetben olvashattuk. Ennek a fajta pásztázási módnak hátránya a nagy időigény. A kromatográfiás vizsgálat időben változó jeleket produkál, tehát egy csúcs tömegspektrometriás mérésére fordítható idő a gyakorlatban legfeljebb néhány másodpercet jelent. Ezért, ha ezt a módszert alkalmazzuk, nem lehet szimultán több komponensre összpontosítani, mert ez nagymértékben csökkentené az érzékenységet. Ezért minden flavonoid aglikonra külön kromatográfiás futtatásból végeztük el a vizsgálatot. Ez a következőképpen néz ki: az aglikon negatív ion módban jellemző deprotonált tömegét adjuk meg, mint olyan tömeget, aminek az anyaionját keressük. Általánosságban elmondható, hogy az a tömegtartomány, amelyböl az anyaionokat várjuk $\mathrm{m} / \mathrm{z}$ 350-től 1000-ig terjedhet. Az eltérő tömegszámú molekulák esetében eltérő nagyságú ütközési energia szükséges (a nagyobbhoz, nagyobb.) Ezért tömegtartományonként eltérő ütközési energiát állítottunk be a prekurzor pásztázás során. Ezek alapján a vizsgált tömegtartomány három részből áll. Az első tartomány $m / z$ 385-500, ahol az egyszerübb származékokat várjuk, mint például a monoglikozidok. Itt az ütközési cellában beállított feszültségérték (CE) -32 V. A második tartomány $m / z$ 500-700-ig terjed, ahol a diglikozidok várhatók. Itt a $\mathrm{CE}$ értéke $-42 \mathrm{~V}$. A harmadik tartomány a maradék tömegszámokat öleli fel $(\mathrm{m} / \mathrm{z}$ 700-1000), itt találhatók a legösszetettebb molekulák. A CE értéke is itt a legmagasabb: -60 V.

Ez a detektálási módszer minden olyan esetben jelet ad, ahol az aglikonnal megegyezö $\mathrm{m} / \mathrm{z}$ értékü fragmens keletkezik, ami nem minden esetben flavonoid származékból képződik. Ennek a problémának a kiküszöbölésére a prekurzorion pásztázással párhuzamosan, a keresett aglikon MRM-jeit is mérjük, természetesen ebben az esetben is mind a három fajta DP érték mellett. Ez a 
módszer egyszerre csak egy flavonoid aglikon származékainak detektálására alkalmas, ezért az általunk előzőleg detektált összes aglikon fajtára le kell futtatni őket.

Ehhez példát először az apigenin bemutatásával adok. A kakukkfüben található apigenin esetében a fő komponens 29,2 perces retenciós időnél jelenik meg (25. ábra). Ez az MRM kromatogram alapján is látható volt. Ezt követően a prekurzorion pásztázás alapján megállapítható volt, hogy a talált apigenin származék deprotonált tömege $m / z$ 445. Ebből kiszámoltuk, hogy a tömegkülönbség az aglikon és a származéka között $176 \mathrm{u}$, mely megfeleltethető egy $\mathrm{C}_{6} \mathrm{H}_{8} \mathrm{O}_{6}$ semleges vesztésnek. Ez nagy valószínűséggel megfelel egy hexozilsav (Hex-a) csoport elvesztésének, ami egy flavonoid-hexozilsav konjugátumra utal. A tipikus polifenol bioszintézis utak ismeretében erről a konjugátumról feltételezhető, hogy a flavonoid aglikon és a vele vízkilépés során konjugálódó glükuronsavból képződött molekuláról van szó. Így ez a komponens feltételezhetően egy apigenin-glükuronid.
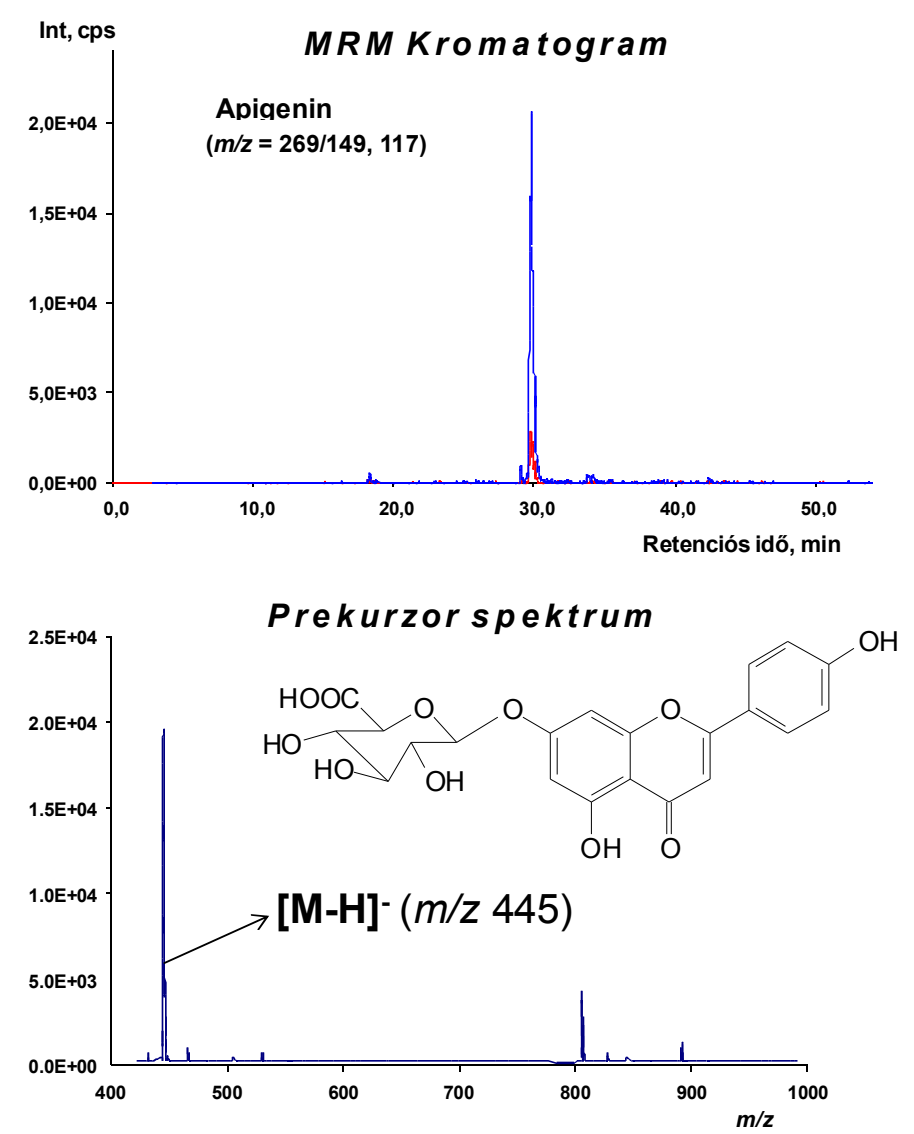

25. ábra: A kakukkfüben található apigenin komponens azonositásához szükséges MRM kromatogram és prekurzor spektrum 
Ugyanezzel a meghatározási módszerrel jártam el a luteolin esetében is, mely a másik fö komponens volt a mintában. A luteolin legintenzívebb származékát a 24.5 percnél találtam (26. ábra). A prekurzor módszer alapján azt kaptam, hogy a származék $\mathrm{m} / \mathrm{z} 461$ tömegü volt. Kiszámolva a tömegkülönbséget az aglikon és a származék között 176 u-t kaptam (ugyan annyit, mint az apigenin esetében) így ezt is azonosítani tudtam luteolin-glükuronid származékként.

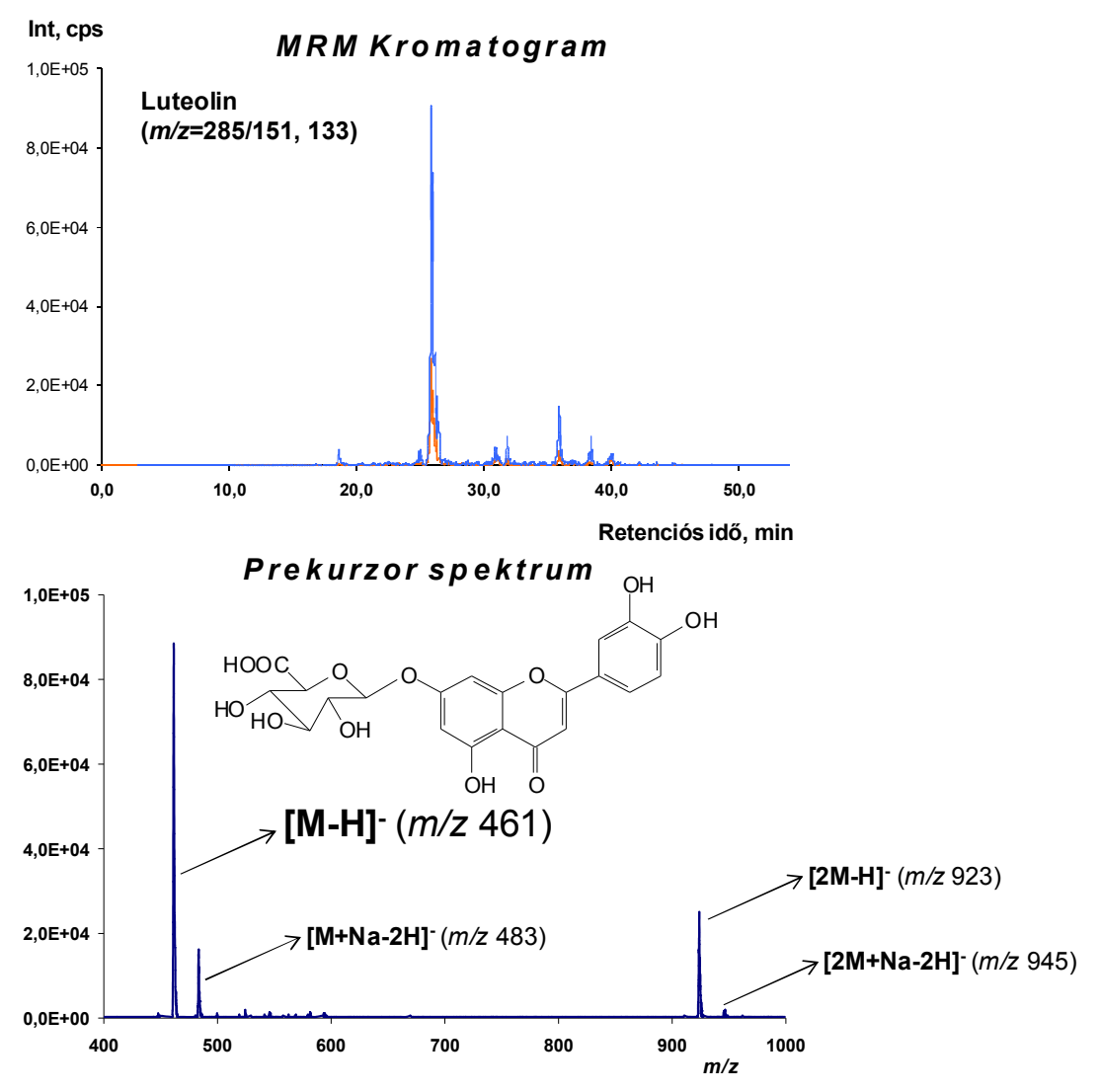

26. ábra: A kakukkfüben található legintenzívebb luteolin komponens azonositásához szükséges MRM kromatogram és prekurzor spektrum

A két kisebb mennyiségben jelen lévő luteolin származékot (25,9 és 35,5 percnél), egy naringenin származékkal együtt azonos módon a jellemző semleges vesztések alapján és a tipikus flavonoid bioszintézis utak ismeretében határoztam meg. Az eredmények a 27. ábrán és a 3. táblázatban láthatóak. 


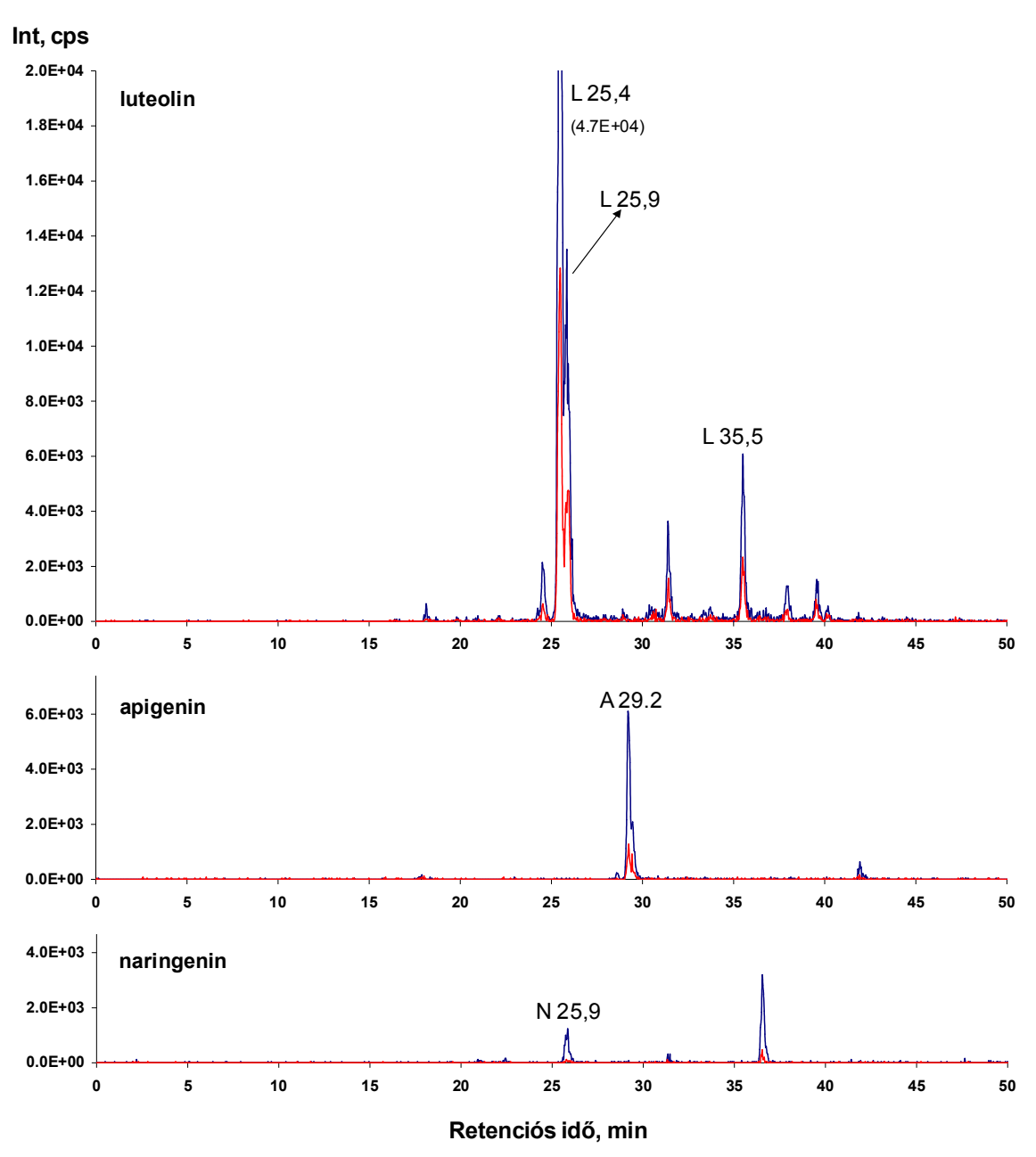

27. ábra: A kakukkfüben található flavonoid komponensek MRM kromatogramjai

3. táblázat: A megtalált flavonoid komponensek a Thymus vulgaris L. mintában ([M-H]': az aglikon iontömege ( $\mathrm{m} / \mathrm{z})$ negativv ion módban, Hex-a: hexozilsav, Hex: hexozid)

\begin{tabular}{cccccc}
\hline aglikon & {$[\mathbf{M}-\mathbf{H}]^{-}$} & $\begin{array}{c}\text { ret.idő } \\
(\mathbf{m i n})\end{array}$ & $\begin{array}{c}\text { megfigyelt } \\
\text { tömeg }(\boldsymbol{m} / \mathbf{z})\end{array}$ & $\begin{array}{c}\text { semleges vesztés } \\
(\mathbf{D a})\end{array}$ & $\begin{array}{c}\text { Feltételezett } \\
\text { származék }\end{array}$ \\
\hline luteolin & 285 & 25,4 & 461 & 176 & Hex-a \\
& & 25,9 & 447 & 162 & Hex \\
& & 35,5 & 609 & 324 & Hex+Hex / \\
& & 29,2 & 445 & 176 & Hex+kávésav \\
\hline apigenin & 269 & 25,9 & 447 & 176 & Hex-a \\
\hline naringenin & 271 & 25 & & \\
\hline
\end{tabular}

Ahogy az a 3. táblázatban látható, a 35,5 percnél eluálódott komponens esetében a prekurzorion $m / z$ 609 volt és nem volt más karakterisztikus fragmentum a spektrumban (pl. $\mathrm{m} / \mathrm{z} 447$, ami egy hexozil vesztésre utalhatott volna). Alapul véve azt, hogy ez egy viszonylag nagy tömegü komponens, feltételezhető, hogy egy komplexebb alegység egyben szakadt le az aglikonról. Jellemzően, ha egy 
acilezett szacharid flavonoid aglikonhoz kötődik, ez a rész egy alegységként szakad le [ABRANKO et al., 2011]. Ezért a 25,9 percnél eluálódó luteolin származék egy kombináció lehet (hexozid (162 Da) és kávésav (162 Da)). Ugyanakkor, ennek a komponensek az azonosítása nem egyértelmü.

A szurokfü esetében ugyanezzel a módszerrel határoztam meg a flavonoid komponenseket. A vizsgálat során kapott MRM kromatogramokat a 28. ábra, az eredmények összefoglalását a 4. táblázat szemlélteti. Ahogy látszik is, ebben a mintában csak apigenin és luteolin komponenseket találtam. A luteolin esetében 4 csúcsot sikerült beazonosítani. Ezek közül az első a 19,95 percnél eluálódott $m / z 637$ tömegü komponens, mely 352 Da-nak megfelelő semleges vesztést jelent. Ez valószínűsíthetően két építőegységből álló konjugátumnak felel meg, melyek a következő kombinációban fordulhatnak elő: két glükuronsav (176+176 Da), vagy egy szinapoil-dezoxihexóz (146+206 Da) mely egy dezoxihexóz és egy szinapinsav kötődésével keletkezik egy víz molekula kilépése mellett. Továbbá még lehetséges egy feruoil-glükuronid $(176+176 \mathrm{Da})$, mely egy glükuronsav és egy ferulasav kötődésével keletkezik egy víz kilépése mellett. A következő komponens 22,2 percnél eluálódott. Itt a megfigyelt tömeg $m / z 623$ volt. Ez 338 Da semleges vesztésnek felel meg. Itt is több variáció lehetséges az azonosítás szempontjából. Egyrészt lehetséges a hexóz (162 Da) egy ferulasavval való kötődése egy víz kilépése mellett (172 Da), mely így luteolin-feruoil-hexozid lenne, másrészt lehetséges egy luteolin-kaffeoil-glükuronid keletkezése, illetve egy luteolin-hidroxiferuoil-dezoxihexóz kialakulása is. A következő két komponens azonosítása könnyebb és egyértelmübb volt. A 25,4 percnél eluálódott komponens esetében a semleges vesztés 176 Da volt, mely egyértelmüvé teszi, hogy ez egy luteolin-glükuronid volt, a 25,8 percél kapott komponenst a $162 \mathrm{Da}-\mathrm{os}$ semleges vesztésével pedig luteolinhexozidként lehetett beazonosítani. A 29,83. percnél szintén egy intenzívebb csúcsot adó komponens található, mely a tömegspektrum alapján $\mathrm{m} / z$ 579 tömeggel rendelkezik. Ez a luteolinhoz kapcsolódott pentóz és egy kávésav vagy egy pentóz és egy hexóz konjugátum lehet. Erről akkor lehetne megbizonyosodni, ha a luteolin pentózzal vagy hexózzal képzett származéka is jelen lenne. Mivel ilyen fragmenst nem találtam, e komponens azonosítása így bizonytalan, ezért ismeretlenként tüntettem fel a táblázatban.

Az apigenin esetében 2 komponenst találtam. Ezek közül az első 23,3 percnél eluálódott m/z 621-es tömeggel, mely a 352 Da semleges vesztést jelent, ugyanúgy, mint az első luteolin komponensnél. Így itt is azok a lehetséges konjugátumok fordulhatnak elö, mint amelyeket már a luteolinnál bemutattam, azaz lehetséges az, hogy ez egy apigenin-diglükuronid vagy egy apigeninszinapoil-dezoxihexóz vagy egy apigenin-feruoil-glükuronid. A következő komponens 29,4 percnél eluálódott és $m / z 445$ tömegü volt, mely egyértelmüen egy apigenin-glükuronid. 


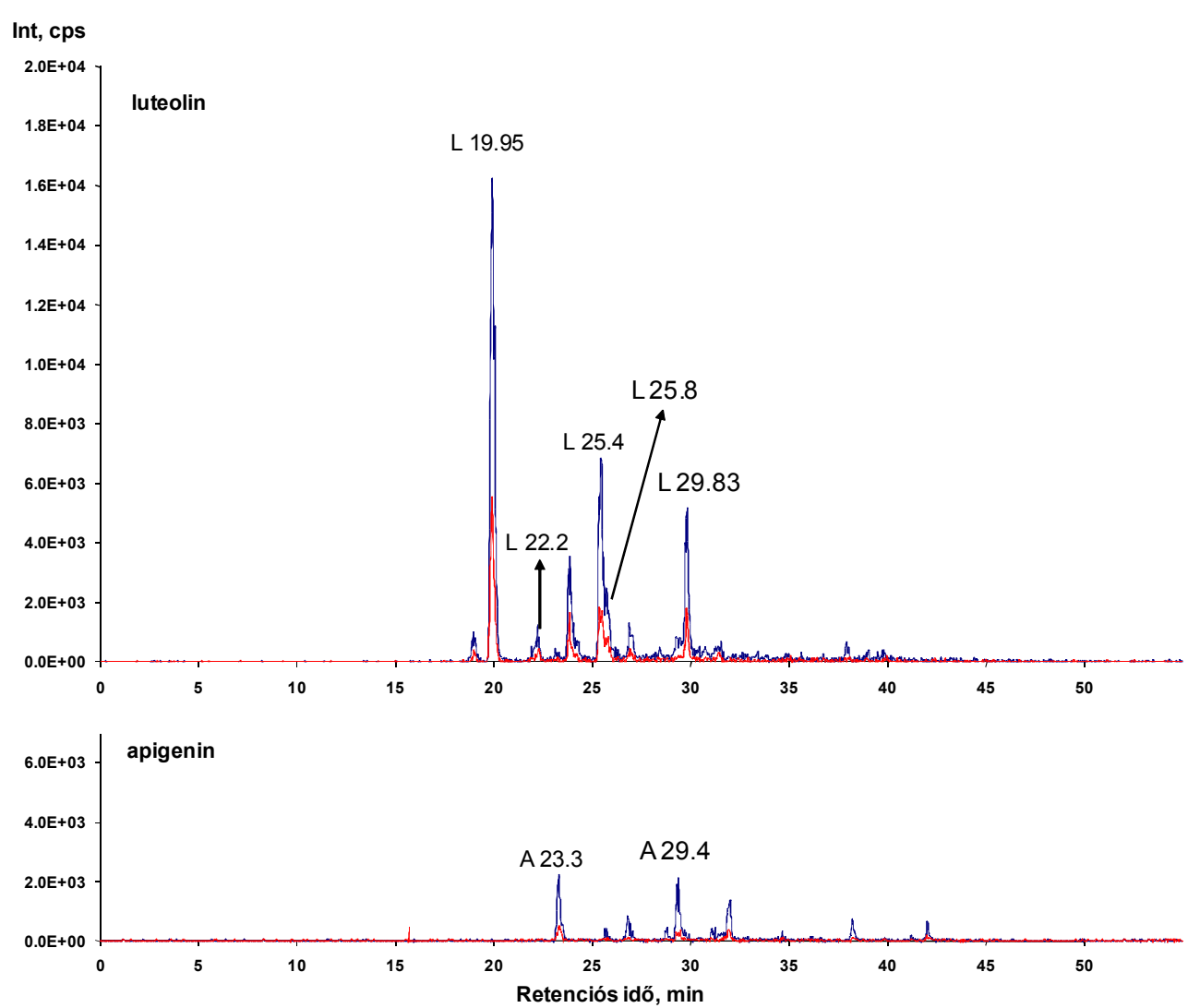

28. ábra: Szurokfüben található luteolin és apigenin komponensek MRM kromatogramja

4. táblázat: A megtalált flavonoid komponensek a szurokfü mintában. ([M-H] : az aglikon tömege $(\mathrm{m} / \mathrm{z})$ negatívion módban, Hex-a: hexozilsav, Hex: hexozid, dH:dezoxihexóz, sz: szinapinsav, f: ferulasav, $k$ : kávésav)

\begin{tabular}{cccccc}
\hline aglikon & $\mathbf{[ M - H}^{-}$ & $\begin{array}{c}\text { ret.idő } \\
(\mathbf{m i n})\end{array}$ & $\begin{array}{c}\text { megfigyelt tömeg } \\
(\mathbf{m} / \mathbf{z})\end{array}$ & $\begin{array}{c}\text { semleges vesztés } \\
(\mathbf{D a})\end{array}$ & feltételezett származék \\
\hline luteolin & 285 & 19,95 & 637 & 352 & Hex-a-Hex-a / dH+sz / Hex-a+f \\
& & 22,2 & 623 & 338 & Hex+f / Hex-a+k/dH+h.f. \\
& & 25,4 & 461 & 176 & Hex-a \\
& & 25,8 & 447 & 162 & Hex \\
& & 29,83 & 579 & 293 & ismeretlen \\
\hline apigenin & 269 & 23,3 & 621 & 352 & Hex-a-Hex-a / dH+sz / Hex-a+f \\
& & 29,4 & 445 & 176 & Hex-a \\
\hline
\end{tabular}

Összefoglalásként elmondható, hogy bár mindkét növény tartalmazott apigenint és luteolint, a komponensek eredeti formája több esetben is különböző volt. A kakukkfü esetében három luteolin, egy apigenin és egy naringenin származékot tudtam azonosítani, míg a szurokfü esetében négy luteolin és két apigenin származék azonosítása sikerült. Naringenin származék a szurokfüből nem volt meghatározható. Ezen kívül az is látszik, hogy a meghatározott származékok esetében a hexozilsav konjugátum volt a leggyakoribb. 


\subsection{Olívaolaj oleuropein-származékainak feltérképező vizsgálata HPLC-ESI-TOFMS technikával.}

Az olívaolaj polifenoljai közül biológiai hatások szempontjából kiemelt jelentőséget tulajdonítanak az oleuropein aglikonnak, illetve származékainak [OMAR, 2010]. Az oleuropein, az oleuropein aglikonnak egy glikozilált formája, melynek szerkezeti képlete az 29. ábrán látható.

A

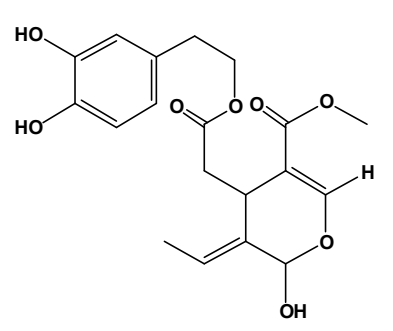

B

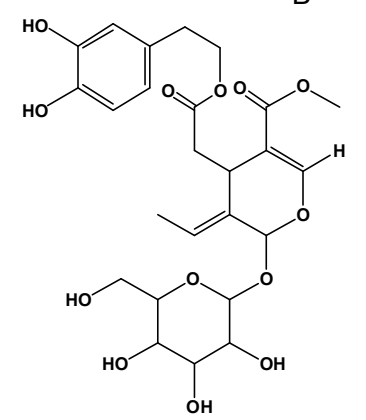

29. ábra: Az oleuropein aglikon (A) $\left(\mathrm{C}_{19} \mathrm{H}_{22} \mathrm{O}_{8}\right.$, neutrális monoizotópos tömeg: 378,1315$)$ és az oleuropein (B) $\left(\mathrm{C}_{25} \mathrm{H}_{32} \mathrm{O}_{13}\right.$, neutrális monoizotópos tömeg: 540,1843) szerkezeti képlete

Az oleuropein olíva termékekből történő vizsgálata ugyanakkor nem triviális feladat, melynek oka, hogy az olíva polifenol-készlete összetett és részletes tanulmányozásához nagy felbontású kromatográfia és szelektív technikák szükségesek. E technikákat alkalmazva Fu és mtsai [FU et al., 2009] valamint legújabban Gilbert-López és mtsai [GILBERT-LÓPEZ et al., 2014] oleuropein- és ligsztrozid aglikonok nem célzott vizsgálata során e vegyületek számos izomer formáját mutatták ki. Kérdésként merül fel azonban, hogy ezek a kimutatott és izomereknek tekintett alkotók valóban az olívaolajban természetes módon, illetve a feldolgozás-technológia során kialakuló izomer formák vagy valami egészen más okból kifolyólag vannak jelen a mintákban. Karkoula és munkatársai egy nemrég napvilágot látott tanulmányukban számos oleuropein (izomer) forma megjelenését tapasztalták, melyek mütermékként jöttek létre, a legáltalánosabban elterjedt $\mathrm{MeOH}$, acetonitril és víz oldószerek és fordított fázisú kromatográfiás fázisok alkalmazása során [KARKOULA et al., 2014]. Vagyis a mérések alkalmával észlelt izomerek nem az olívaolaj endogén alkotói, hanem az analitikai eljárások eredményeképpen jelennek meg a mintákban. Hipotézisként merült fel az a lehetőség is, hogy Fu és mtsai, illetve Gilbert-López és mtsai által jelzett oleuropein aglikon izomerek valójában nem izomerek, hanem valamilyen oleuropein származékok, melyek a tömegspektrometriás mérés során, az ionforrásban fragmentálódtak és az így kialakult oleuropein aglikon került detektálásra. Vizsgálataim során tehát nem célzott módon történő tömegspektrometriás vizsgálatokat hajtottam végre annak érdekében, hogy az előbbi hipotézist vizsgálhassam. A folyadékkromatográfiás elválasztást követő teljes letapogatású TOFMS vizsgálatok lehetővé teszik, hogy az oleuropein származékokat nem célzott módon 
vizsgálhassam. A vizsgálataimhoz Fu és mtsai 2009-es munkáját vettem alapul [FU et al., 2009]. Ebben a munkában az oleuropeint nem mutatták ki, de az oleuropein aglikon negatív ion módban keletkezett deprotonált ionos formájának $\left(\mathrm{C}_{19} \mathrm{H}_{21} \mathrm{O}_{8}, \mathrm{~m} / \mathrm{z} 377,1242\right)$ pontos tömegére jellemzö kromatogramon számos csúcs található (30. ábra). Ez a megfigyelés egybeesik Gilbert-López és mtsai-nak későbbi megfigyeléseivel is.

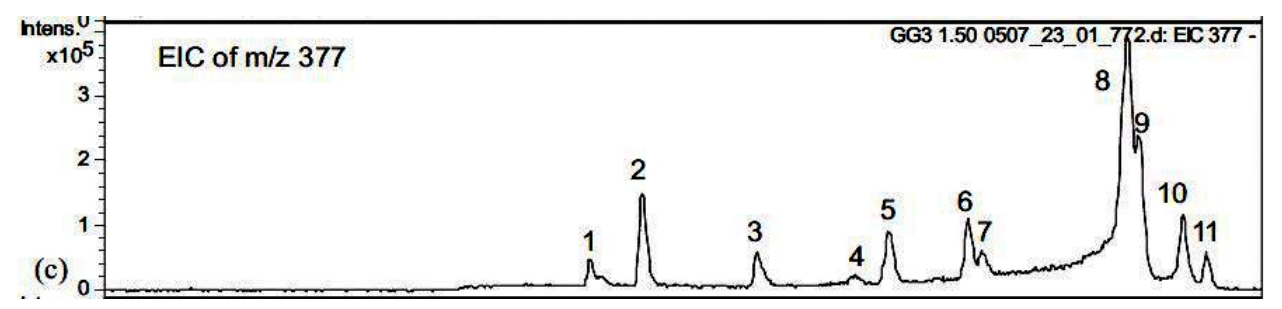

30. ábra: A Fu és mtsai (2009) által közölt cikkben lévö m/z 377,1242 EIC kromatogram olívaolajból

Az m/z 377,1242-es tömegü ion kiemelt ionkromatogramján látható kromatográfiás csúcsok tömegspektrumait megvizsgálva azt lehet látni, hogy az $\mathrm{m} / \mathrm{z}$ 377,1242-es iontömeg felett nem találni további nagy gyakoriságú ionokat (31. ábra). Azaz a cikk szerint az oleuropein aglikonok önmagukban, és nem származékként voltak jelen az olajban.
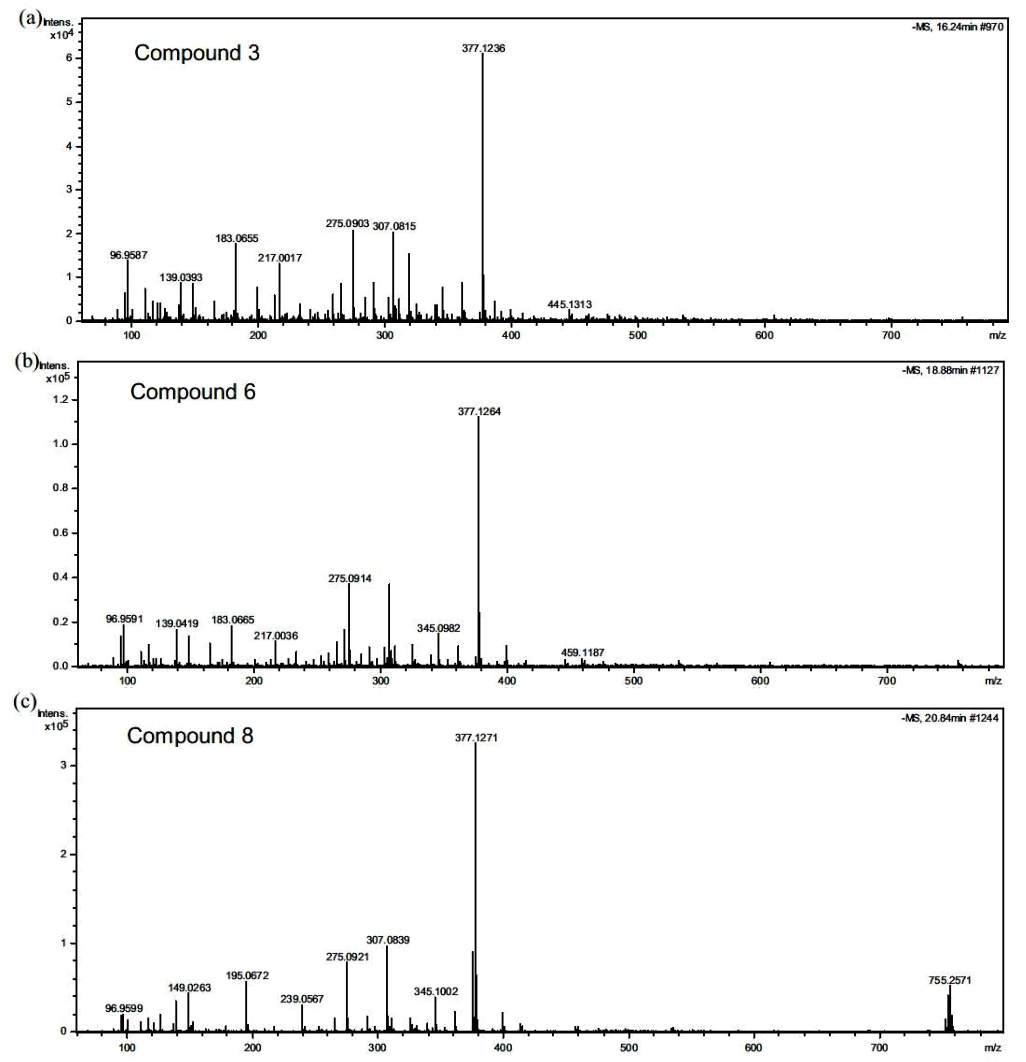

31. ábra: A Fu és mtsai (2009) által közölt cikkben lévö, olívaolajból vizsgált oleuropein aglikon $(\mathrm{m} / z$ 377,1242) kiemelt ionkromatogramja alapján kapott tömegspektrumok három kiválasztott csúcs esetében 
A kutatás során tandem MS kísérletekben fragmentálták is az oleuropein aglikon molekulát és az eredmények azt mutatták, hogy ott ahol az $m / z$ 377,1242-es csúcsok megjelentek, ott az oleuropein aglikonra jellemző fragmentumok is jelet adtak, tehát igazolt az oleuropein aglikon jelenléte. Ezekből az adatokból azt is bizonyítottnak vélték, hogy ezek a komponensek oleuropein aglikon izomerek. Mivel kísérleteimben célom az volt, hogy megvizsgáljam, vajon ezek az oleuropein komponensek valóban izomerek vagy esetleg van olyan fölső tömeg, mely származék jelenlétére utal, a cikkben közöltekhez hasonló minta-előkészítést és kromatográfiát alkalmaztam.

Kíváncsi voltam arra is, hogy az olajokon kívül a levélben illetve a bogyóban is vannak-e hasonló komponensek. Ezen két mintához egy újfajta minta-előkészítést alkalmaztam, melyet Accelerated Solvent Extraction-nek hívnak. Ez a módszer kíméletesen, de hatékonyan tudja kivonni a vizsgálni kívánt komponenseket. Ezen módszer pontos bemutatása az 4.4. Minta-előkészítés fejezetben olvasható.

Vizsgálataimat az olívaolajokkal, azon belül először a „Borges” olajjal kezdtem, melynek total ionkromatogramjából (TIC) az m/z 377,1242 tömegü aglikon negatív ionos formáját extraháltam ki, megkapva a kiemelt ionkromatogramot (angolul Extracted Ion Chromatogram, EIC) (32. ábra). Kiemelt ionkromatogram alatt a teljes letapogatás (full scan) módban felvett kromatogramnak (totál ionkromatogram) egy kellően keskenyre választott tömegablakba eső részletét értjük. Jelen munkában a tömegablakot $\pm 0,005$ Da szélességünek vettem.

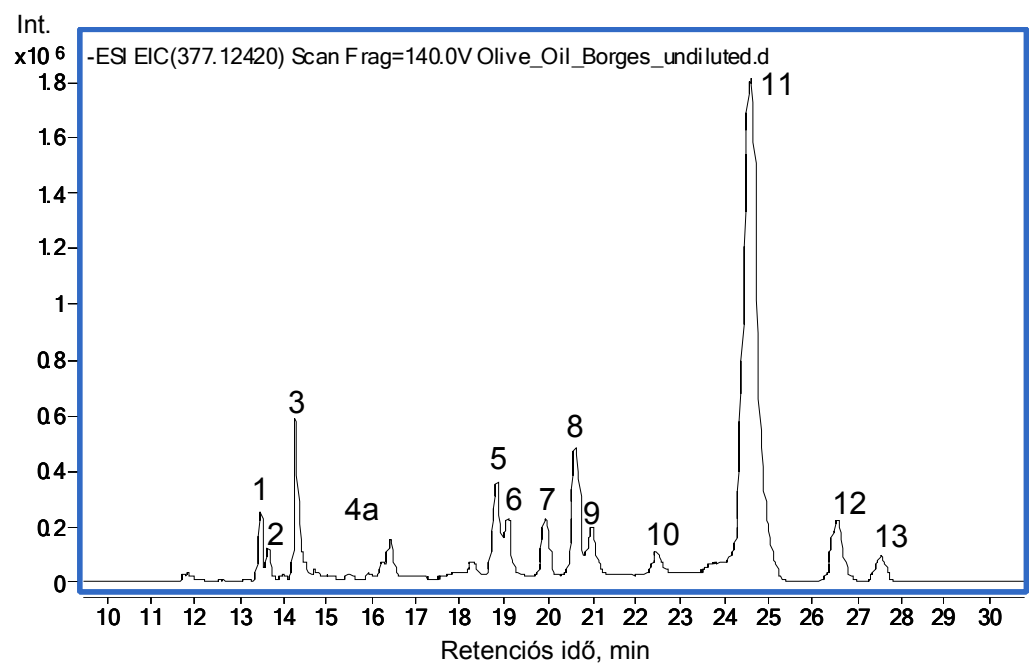

32. ábra: „Borges” olívaolaj vizsgálatakor kapott kiemelt ionkromatogram az m/z 377,1242 tömegre

Ezt követően az egyes csúcsokat integrálva, megvizsgáltam a tömegspektrumokat. A csúcs spektrum alatt háttérkorrigált csúcsspektrumot kell érteni. Ilyenkor a csúcs kezdetén és végén (a 
csúcsmagasság 10\%-ánál) lévő két spektrum átlagát tekintettem háttérspektrumnak. A háttérkorrekció során a szoftver ezt az átlagos háttérspektrumot vonta ki a csúcs -10\%-os magasság között található - további spektrumaiból. Végül a háttérkorrigált spektrumok átlaga jelent meg, mint háttérkorrigált csúcsspektrum.

A csúcsspektrumban található, az aglikonnál nagyobb tömegü ionok kromatográfiás lefutását összehasonlítottam az aglikon kiemelt ionkromatogramjával. Amennyiben a két tömeghez tartozó ionkromatogramon a vizsgált csúcs esetében a csúcsalak illetve a csúcsmaximum azonos, nagy valószínüséggel egy azonos molekulához tartoznak, azaz a nagyobb tömegü ion az aglikonnak valamely származéka lehet.

Az első vizsgált olaj esetében erre a munkafolyamatra példaként 27,5 pernél érkező csúcs spektrumát mutatom be, mely az 33. ábrán látható.

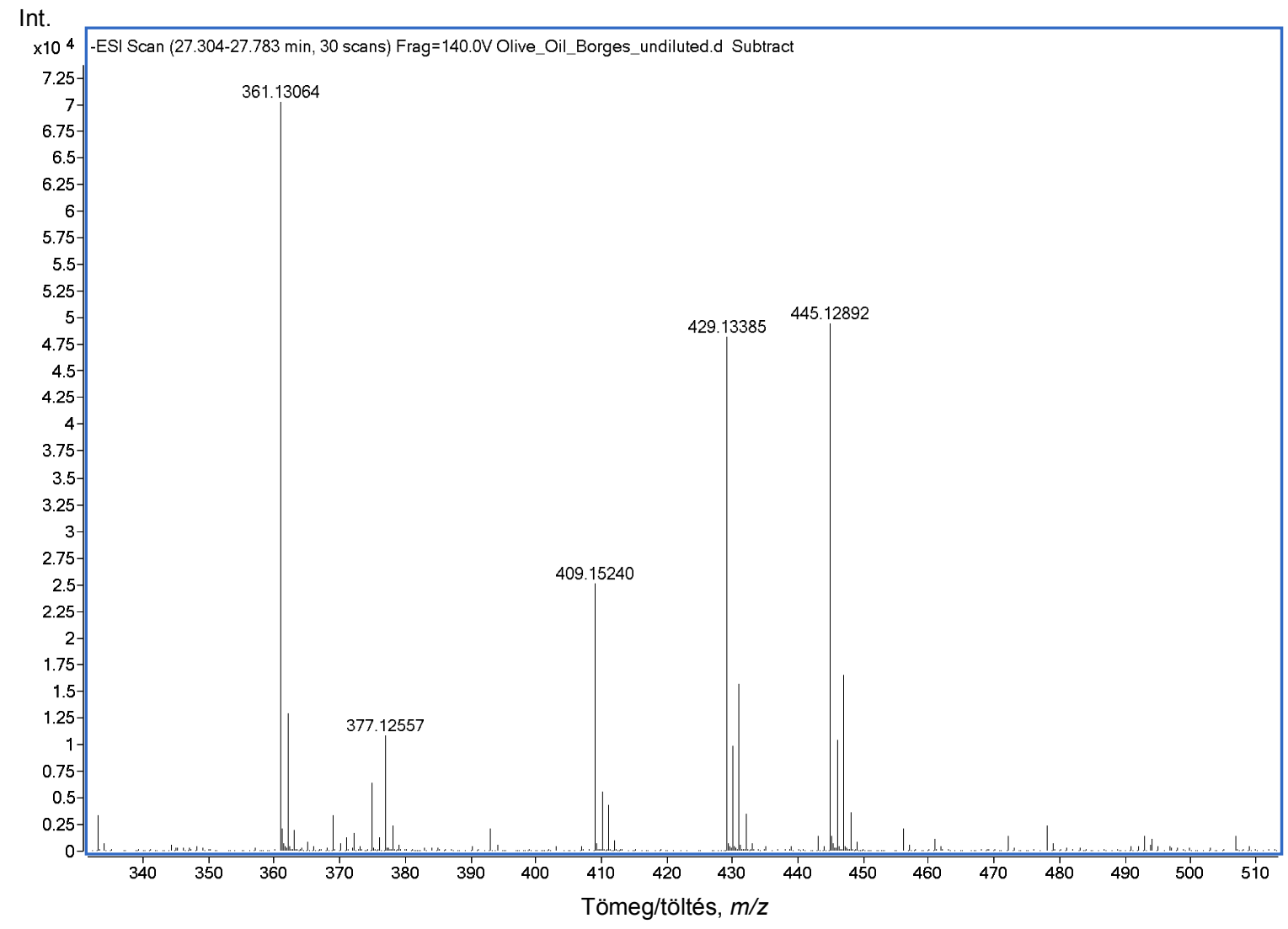

33. ábra: A 27,5 percnél érkezö csúcs tömegspektruma 
A tömegspektrumból jól látszik, hogy az $m / z$ 377,1242-es komponensen kívül, nem elhanyagolható a három másik, ennél nagyobb tömeggel rendelkező komponens jelenléte. Ezeknek a komponenseknek a kromatogramját elemezve megállapítható, hogy tényleg az oleuropein aglikonhoz tartoznak-e. Az m/z 409,1524 illetve az m/z 445,1289 esetében kapott kromatogramot a 34. ábrán láthatjuk.

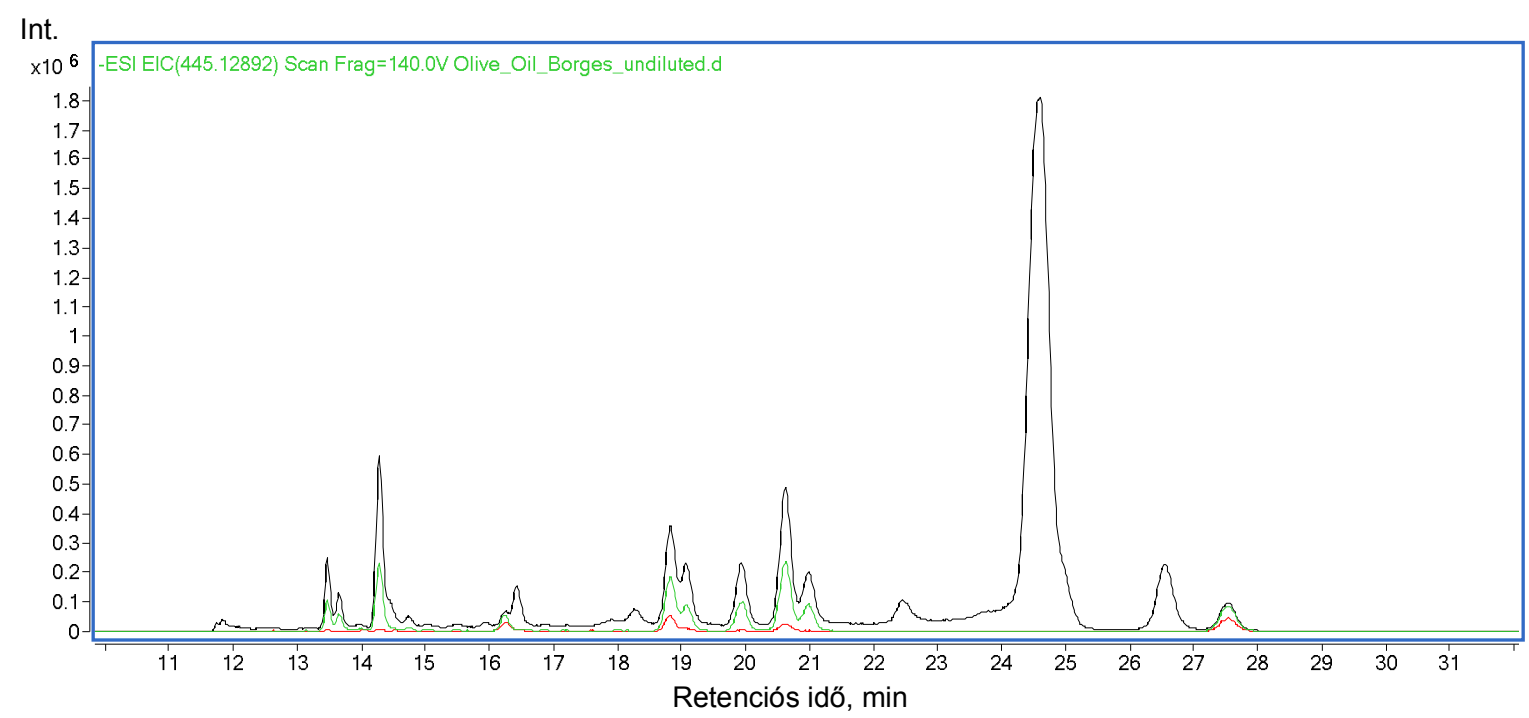

34. ábra: A „Borges” olívaolaj vizsgálatakor kapott kiemelt ionkromatogramok, fekete: $\mathrm{m} / \mathrm{z}$ 377,1242, piros: $\mathrm{m} / \mathrm{z}$ 409,1524, zöld: $\mathrm{m} / \mathrm{z} 445,1289$

Az ábrából jól látszik, hogy 9 darab $\mathrm{m} / z$ 377,1242 ionhoz valószínüsíthetően tartoznak nagyobb tömegü ionok. Ezek az $m / z$ 409,1524; 445,1289 tömegü ionok, melyek kromatográfiás viselkedése egyező az $\mathrm{m} / z$ 377,1242 tömegü ionnal.

A tömegspektrumon látható volt egy $\mathrm{m} / \mathrm{z}$ 429,1339 -es tömegszámú komponens is, melynek kinagyított kromatogramja a 35. ábrán látható. 


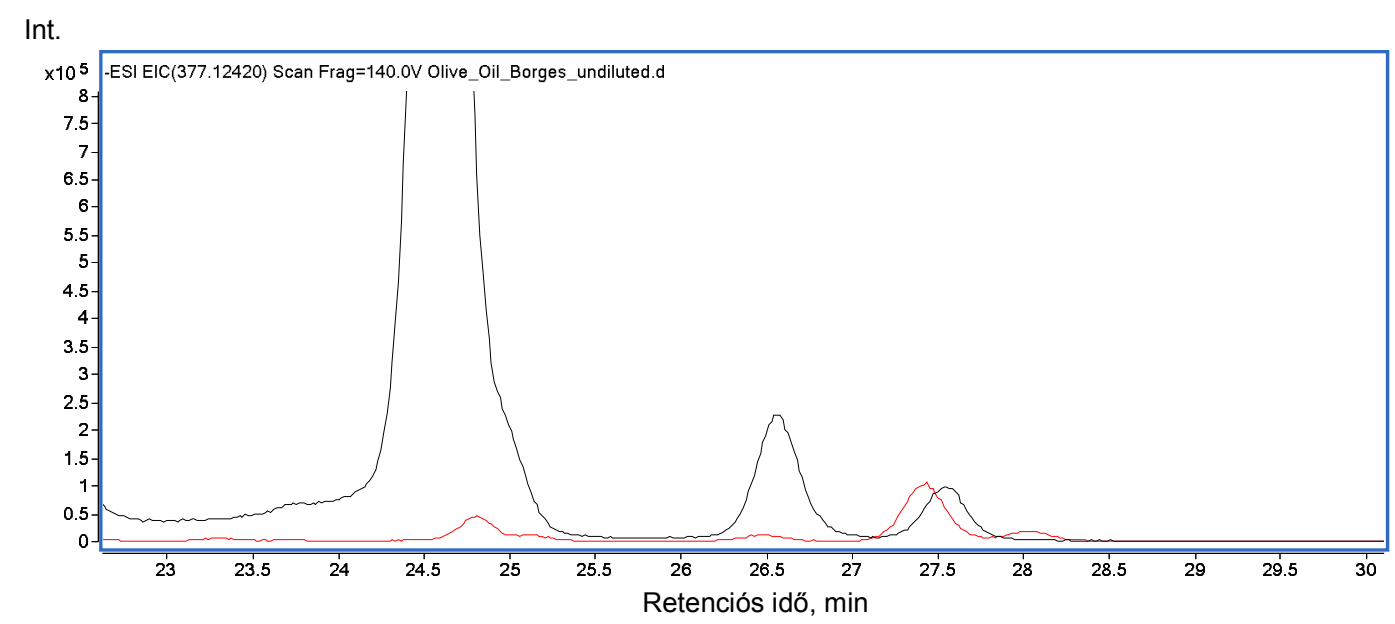

35. ábra: Az m/z 429,13385 tömegü komponens kromatogramja (piros) az m/z 377,1242 tömegü komponenssel együtt (fekete)

Itt az előzőekkel ellentétben, nincs egyezőség a kromatográfiás lefutások között, így ez a komponens nem áll kapcsolatban az oleuropein aglikonnal.

A szoftver adatbázisára támaszkodva, az izotópmintázatot és a pontos izotóptömegeket alapul véve ezt az $m / z$ 409,1524 iontömegü komponenst $\mathrm{C}_{20} \mathrm{H}_{25} \mathrm{O}_{9}$ összeképlettel azonosította a szoftver, mely megfeleltethető az aglikon egy olyan származékának, mely $\mathrm{CH}_{4} \mathrm{O}$ molekularészlettel több, mint az eredeti aglikon. Ez felírható az alábbi formában is: [ $\left.\mathrm{M}+\mathrm{CH}_{4} \mathrm{O}-\mathrm{H}\right]^{-}$. Más szavakkal, az eredeti molekula $\mathrm{CH}_{4} \mathrm{O}$ semleges vesztés következtében képződő fragmense megfeleltethető egy olyan molekulának, melynek össszegképlete megegyezik az oleuropein aglikonéval.

Amennyiben ezt az eredeti molekulát az oleuropein aglikon származékaként képzeljük el, akkor ez egy hidroxilcsoport $(-\mathrm{OH})$, egy metilcsoport $\left(-\mathrm{CH}_{3}\right)$, továbbá egy kettős kötés telítődésének $\left(\mathrm{H}_{2}\right.$ addíció) együttes megjelenésével jöhet létre. Ez megjelenhet akár egy metoxicsoport $\left(-\mathrm{O}-\mathrm{CH}_{3}\right)$ kapcsolódásával és egy kettős kötés egyidejü telítődésével. Az oleuropein aglikon molekula esetében ezeknek a kis molekularészleteknek a befogadására számos alkalmas hely áll rendelkezésre. Mi több, ezek többféle kombinációban is megjelenhetnek, mely magyarázatot adhat a több kromatográfiás csúcs megjelenésére. Ugyanakkor ezek a bekövetkező változások kellően kismértékünek tekinthetők ahhoz, hogy a fragmentációs képet ne befolyásolják jelentős mértékben.

$\mathrm{Az} m / z$ 445,1289 tömeget $\mathrm{C}_{20} \mathrm{H}_{26} \mathrm{O}_{9} \mathrm{Cl}$ komponensként azonosította a program, mely feltehetően a fentebb tárgyalt $\left(\mathrm{m} / \mathrm{z} 409,1524\right.$ iontömegü $\mathrm{C}_{20} \mathrm{H}_{25} \mathrm{O}_{9}$ összeképletü) oleuropein aglikon származék klorid adduktja, azaz $\left[\mathrm{M}+\mathrm{CH}_{4} \mathrm{O}+\mathrm{Cl}\right]^{-}$. A klorid addukt és az alapmolekula együttes jelenléte (pl.: a vizsgált „Borges” olaj esetén 18,8; 20,0 illetve 20,8 percnél érkező komponensek esetén), tovább erősíti az m/z 409,1524 iontömegü, $\mathrm{C}_{20} \mathrm{H}_{25} \mathrm{O}_{9}$ összeképletü alkotó azonosítását. 
A 26,5 percnél megjelenő csúcsot megvizsgálva más tömegspektrumot kaptam. Ahogy az a 36. ábrán látszik, az előző tömegspektrummal ellentétben, itt az $m / z$ 413,1018-as mért monoizotópos iontömeg található meg. Szintén a szoftver adatbázisa, az izotópmintázat és a pontos izotóptömegek alapján ez egy $\mathrm{C}_{19} \mathrm{H}_{22} \mathrm{O}_{8} \mathrm{Cl}$ összegképletű alkotó, mely vélhetően az oleuropein aglikon klorid adduktja.

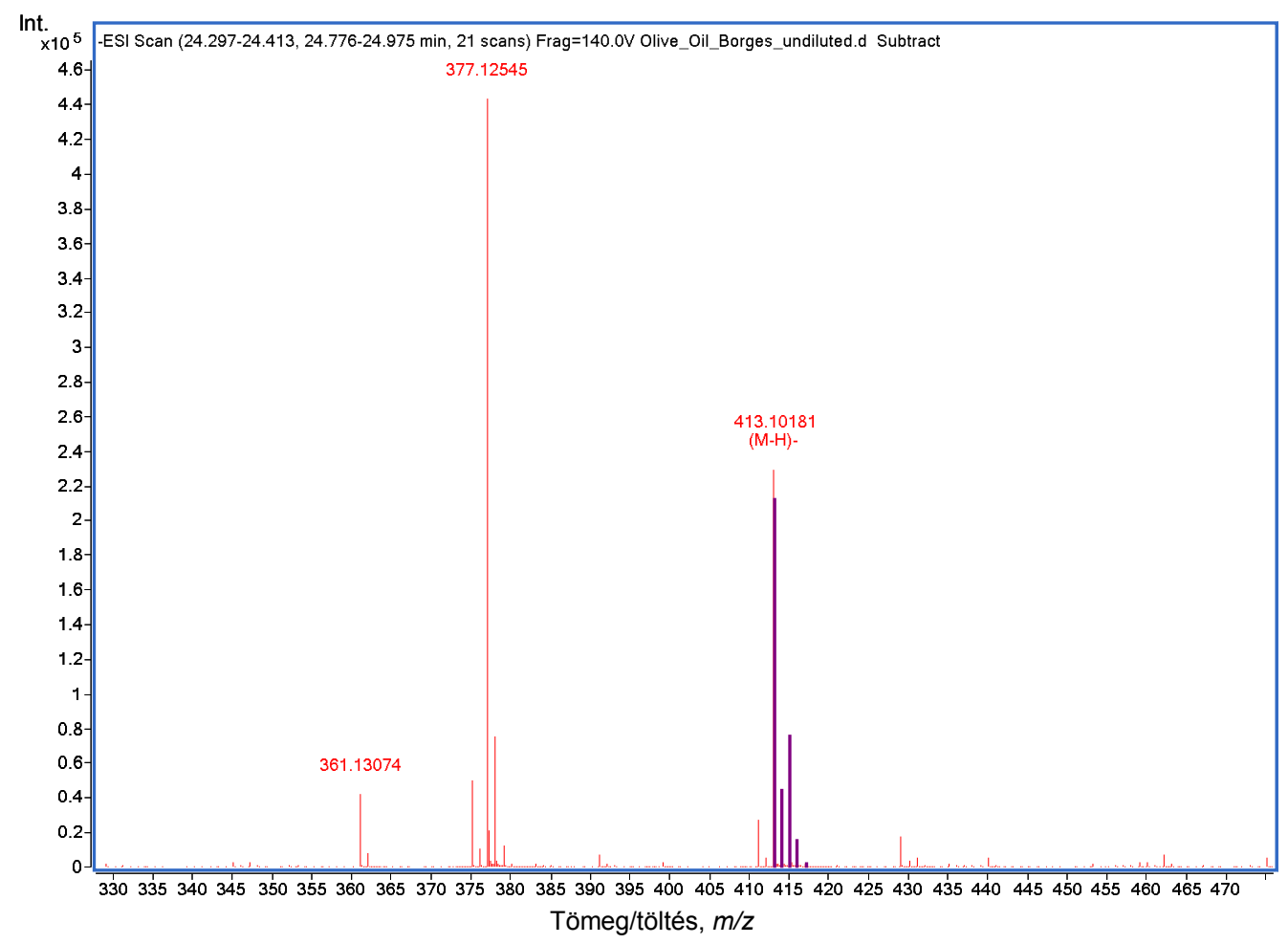

36. ábra: A 26,5 percnél érkezö csúcs tömegspektruma

A $\mathrm{C}_{19} \mathrm{H}_{22} \mathrm{O}_{8} \mathrm{Cl}$ összegképlethez tartozó elméleti pontos monoizotópos iontömeg $(\mathrm{m} / \mathrm{z}$ 413,1026) alapján készített kiemelt ionkromatogramokon látszik, hogy az $\mathrm{m} / \mathrm{z}$ 413,1026-as iontömegü molekula három $\left(t_{R}=16,4\right.$ perc, 24,5 perc és 26,6 percnél érkezö) oleuropein aglikonnak megfelelő $\mathrm{m} / \mathrm{z}$ 377,1242 ion kromatográfiás csúcsával egyező profillal eluálódik (lásd 37. ábra). 


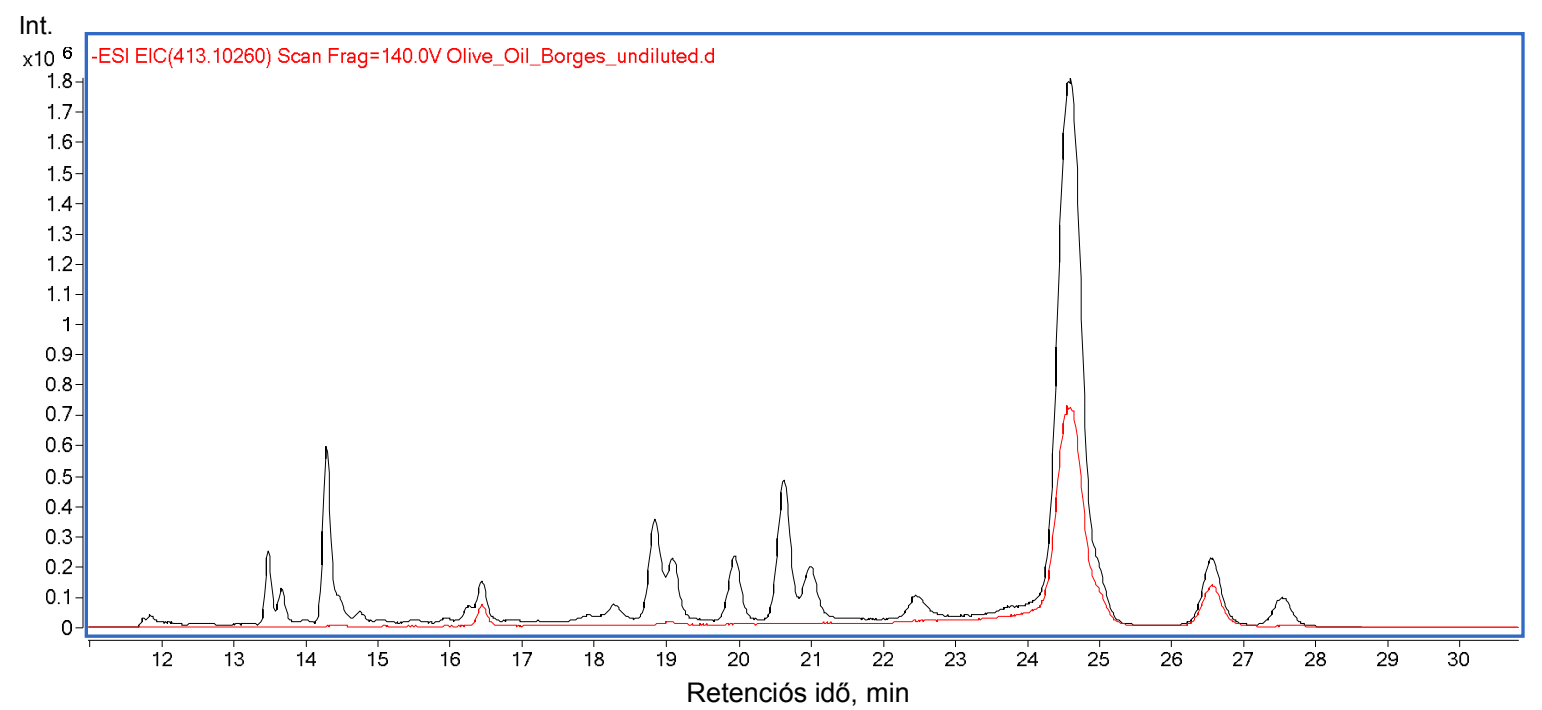

37. ábra: A „Borges” olívaolaj vizsgálatakor kapott kiemelt ionkromatogramok piros: $\mathrm{m} / \mathrm{z}$ 413,1026, fekete: $\mathrm{m} / \mathrm{z} 377,1242$

Így ezek az m/z 377,1242 iontömegü aglikonhoz köthető ionoknak tekinthetők, és minden bizonnyal az oleuropein aglikon (izomerek) klorid adduktjairól van szó. Ez azt igazolja, hogy ez a három ( $\mathrm{t}_{\mathrm{R}}=16,6$ perc, 24,5 perc és 26,6 perc) alkotó nagy valószínüséggel valóban oleuropein aglikon izomernek tekinthető. A vizsgált olajminta kapcsán meg kell ugyanakkor említeni, hogy oleuropeint $(m / z 539,1770)$ nem találtam a mintában. Ez utóbbi megfigyelés összevág Fu és mtsai [FU et al., 2009], valamint Gilbert-López és mtsai [GILBERT-LÓPEZ et al., 2014] megfigyeléseivel.

Kíváncsi voltam, hogy más fajta olaj esetén is megtalálom-e ezeket az iontömegeket, ezért egy másik, „Fuenroble” nevü olajon is elvégeztem a kísérletet. Ezen olaj esetében az $\mathrm{m} / \mathrm{z}$ 377,1242 ion kiemelt ionkromatogramját a 38. ábrán láthatjuk. Ez nagymértékben megegyzik az előző olaj esetében kapott ionkromatogrammal. Eltéréseket a 18-21. perc közötti időintervallumban tapasztalhatunk. Továbbá, a 27,5 percnél eluálódott komponens is hiányzik, azonban arról már kiderült, hogy feltehetően nem is oleuropein származék volt. Szembetűnő azonosság, hogy ennél az olajnál is a 24,8 perc környékén eluálódik a fö komponens. 


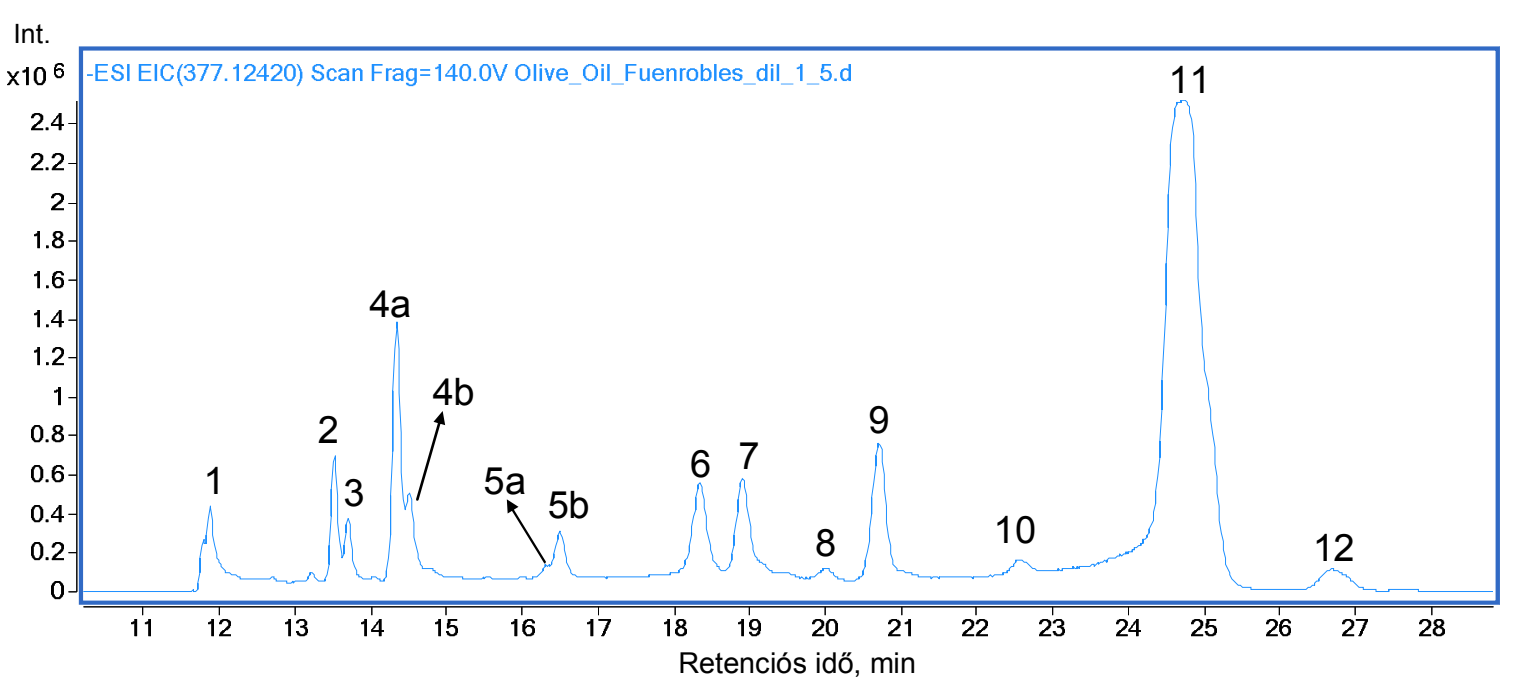

38. ábra: „Fuenroble” olaj kiemelt ionkromatogramja, $m / z$ 377, 1242

Ennél az olajnál is az előzőleg bemutatott metodikát követtem és megvizsgáltam a jellemző csúcsokat, annak érdekében, hogy megtudjam, milyen, az aglikonnál nagyobb tömegü komponensek lehettek még jelen. Itt is ugyanazokkal az ionokkal találkoztam, mint az előző minta esetében. Így jellemző ionként jelent meg az m/z 409,1519, az m/z 445,1286 és az m/z 413,1024.

Az $m / z$ 413,1024, melyet az oleuropein aglikon $\mathrm{Cl}$ adduktjaként azonosítottunk, az $m / z$ 377,1242 (oleuropein aglikon) ionnal együtt, a „Fuenroble” olajnál is annál a három csúcsnál $\left(t_{R}=16,6\right.$ perc, 24,8 perc és 26,7 perc) volt kimutatható mint a vizsgált „Borges” olaj esetében (lásd 39. ábra). Erről a három csúcsról joggal feltételezhető, hogy oleuropein izomerek.

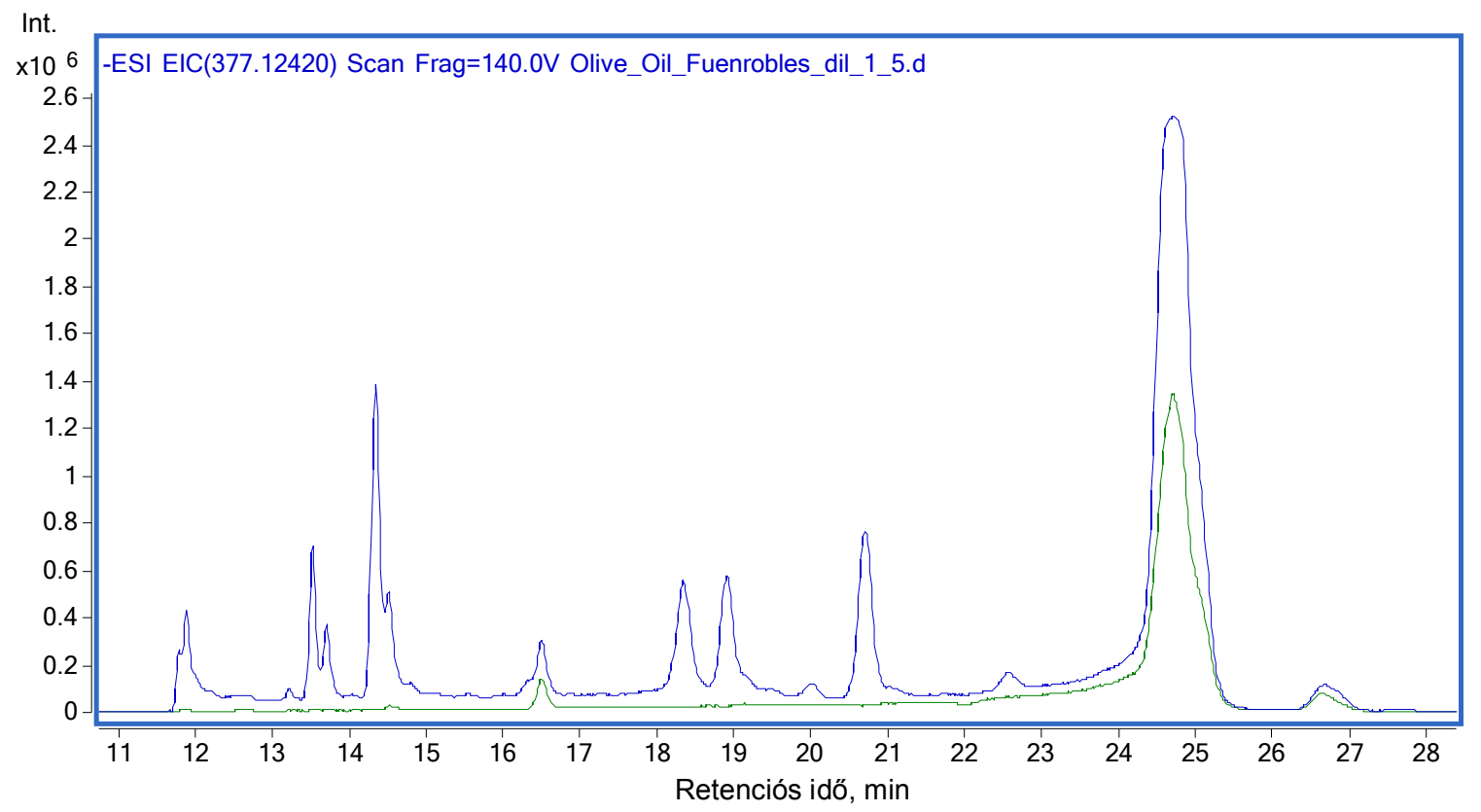

39. ábra: „Fuenroble” olaj kiemelt ionkromatogramja, m/z 413,1024 (zöld), m/z 377,1242 (kék) 
Az $m / z$ 409,1519 iontömegü alkotó, melyet korábban oleuropein aglikon $\left[\mathrm{M}+\mathrm{CH}_{4} \mathrm{O}-\mathrm{H}\right]^{-}$ származékként azonosítottunk és e feltételezett származék klorid adduktja $(\mathrm{m} / \mathrm{z} 445,1286)$ a 14 csúcsból, 3 csúcs esetében jelent meg együtt az $\mathrm{m} / \mathrm{z}$ 377,1242 ionnal. Ezek így együtt már meggyőző bizonyítéknak tekinthetők, hogy az oleuropein aglikon $\left[\mathrm{M}+\mathrm{CH}_{4} \mathrm{O}-\mathrm{H}\right]^{-}$származékai. Az igazoláshoz felhasznált ionok kiemelt ionkromatogramjait a 40. ábra mutatja. Látható, hogy érdekes módon, az $\mathrm{m} / \mathrm{z}$ 445,1286 (a feltételezett származék klorid adduktja) 14 kromatográfiás csúcs közül 7 esetben adott jelet.

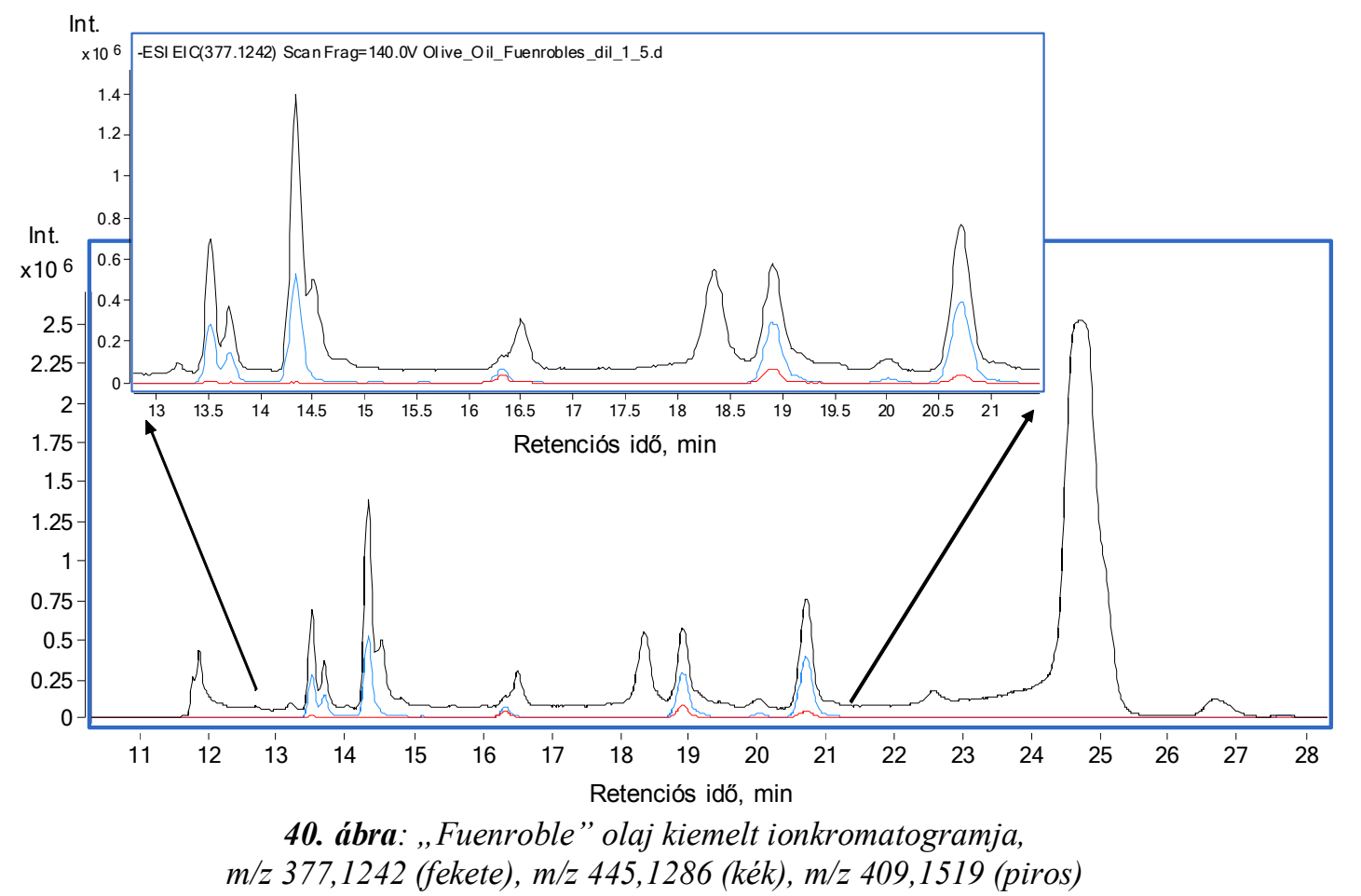

Ezekről a csúcsokról elmondható, hogy az oleuropein aglikon $\left[\mathrm{M}+\mathrm{CH}_{4} \mathrm{O}-\mathrm{H}\right]^{-}$származéka ( $m / z$ 409,1519) nem, csak annak klorid adduktja volt kimutatható. Ez azonban így nem tekinthetö kellően egyértelmü bizonyítéknak arra vonatkozóan, hogy ezek a csúcsok az $\left[\mathrm{M}+\mathrm{CH}_{4} \mathrm{O}-\mathrm{H}\right]^{-}$ származékok volnának. A „Fuenroble” olaj esetében végzett vizsgálatok alapján elmondható, hogy a $14 \mathrm{~m} / z$ 377,1242 tömegszámra kapott csúcs közül 3 csúcs esetében egyértelmü eredményeket kaptam arra vonatkozólag, hogy az oleuropein aglikon $\left[\mathrm{M}+\mathrm{CH}_{4} \mathrm{O}-\mathrm{H}\right]^{-}$formában van jelen, 4 esetben pedig csak indirekt módon (a klorid addukt detektálásával) sikerült ezt bizonyítani. Megjegyzendő, hogy oleuropein $(\mathrm{m} / z$ 539,1770) a „Fuenroble” mintánál sem található.

Meg kell továbbá említeni, hogy az olajok esetében a 24.8 percnél eluálódó, legnagyobb csúcsot adó $\mathrm{m} / \mathrm{z}$ 377,1242 ionról sem tudható biztosan, hogy oleuropein aglikon, ugyanis hasonlóképpen mint $\mathrm{Fu}$ és mtsai, valamint Gilbert-López és mtsai - mi sem rendelkeztünk oleuropein aglikon referencia anyaggal, hogy ezt kromatográfiás egyezőségre alapozva 
megerősítsük. Annak érdekében, hogy házilag előállítsuk az oleuropein aglikont, kísérletet tettünk az oleuropein elhidrolizálására. Ehhez $10 \mathrm{ml} 18 \mathrm{mM}$ koncentrációjú oleuropein standard vizes oldatához adtunk $1 \mathrm{~N}$ koncentrációjú kénsav oldatot, majd ezt $55{ }^{\circ} \mathrm{C}$-on 2 órán keresztül inkubáltuk, miközben fél óránként mintát vettünk [CAPASSO et al., 1997]. Az alkalmazott hidrolízis azonban nem bizonyult kellően hatékonynak, azaz nem keletkezett detektálható mennyiségü oleuropein aglikon. Ezek alapján tehát nem tudtam az oleuropein aglikon retenciós idejét standard anyag segítségével megerősíteni, ugyanakkor mindez nem befolyásolja a feltételezett izomerekkel kapcsolatos korábban tett megállapításaimat.

A témakörhöz tartozó további kísérletemben az olívalevelet és bogyót is megvizsgáltam. Mivel egyik mintatípus esetén sem alkalmazható az olajra kidolgozott minta-előkészítés, ezért mind az olívalevél, mind pedig a bogyó esetében az 4.4. Minta-előkészítés fejezetben részletezett ún. ASE szilárd-folyadék extrakciót alkalmaztam.

Az olívalevél és a bogyó esetén is az olajhoz hasonló megközelítésben kerestem az oleuropein formákat. Az olívalevél esetében kapott m/z 377,1242 kiemelt ionkromatogramja a 41. ábrán látható.

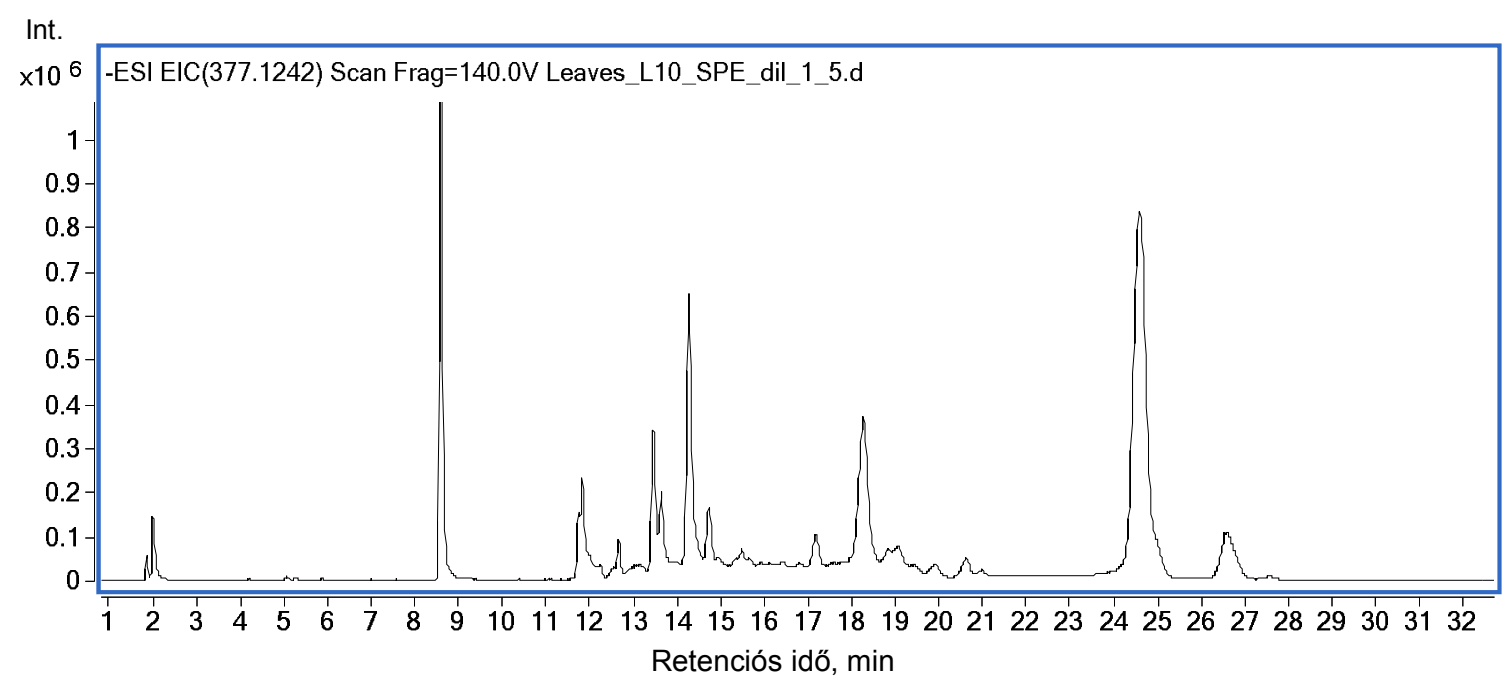

41. ábra: Olívalevélben lévö m/z 377,1242 iontömegü komponensek kiemelt ionkromatogramja

Az olívalevél esetében is azok voltak az $\mathrm{m} / \mathrm{z}$ 377,1242-es iontömegnél nagyobb tömegek, mint a két olajnál, bár az $m / z$ 409,1519 legtöbbször a detektálás határát jelentő mennyiségben volt jelen. Az $m / z$ 445,1286 illetve az elöbb említett $m / z$ 409,1519 iontömegü komponensek kiemelt ionkromatogramjai a 42. ábrán láthatóak. 


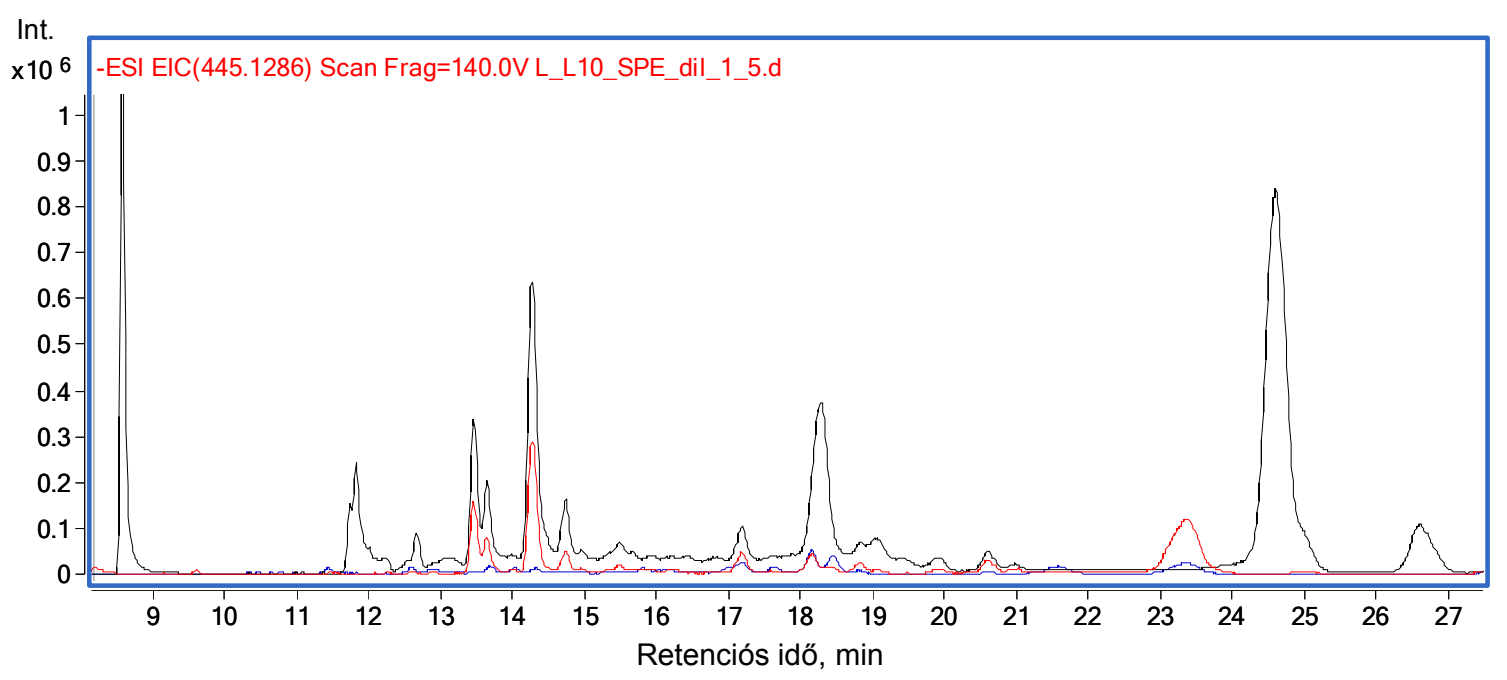

42. ábra: Olivalevél $\mathrm{m} / \mathrm{z} 445,1286$ (piros) és $\mathrm{m} / \mathrm{z}$ 377,1242 (fekete), $\mathrm{m} / \mathrm{z} 409,1519$ (kék) kiemelt ionkromatogramja

Ahogy az a 42. ábrán látható, az $m / z$ 409,1519 ([M+CH $\left.4 \mathrm{O}-\mathrm{H}]^{-}\right)$iontömegü komponensek a detektálási határon mozogtak és az $m / z$ 445,1286 ([M+C $\left.\left.\mathrm{CH}_{4} \mathrm{O}+\mathrm{Cl}\right]^{-}\right)$iontömegü komponenssel két csúcs esetében, a 14,3 és 17,2 perces retenciós időnél mutatott a kromatográfiás lefutásban egyezőséget. Azonban az $m / z$ 445,1286 iontömegü molekula ezen két csúcson kívül még további öt esetben mutatott azonos kromatográfiás lefutási képet az $\mathrm{m} / \mathrm{z}$ 377,1242 iontömegü oleuropein aglikonnal. Az m/z 413,1024 iontömegü ([M+Cl]) komponens kiemelt ionkromatogramján (43. ábra) egyértelműen látszik az olajok esetében is detektált három csúcs közül kettő $\left(t_{R}=24,6\right.$ perc és 26,7 perc). Ebben a mintában található volt oleuropein, melynek kiemelt ionkromatogramját a a 44. ábra mutatja.

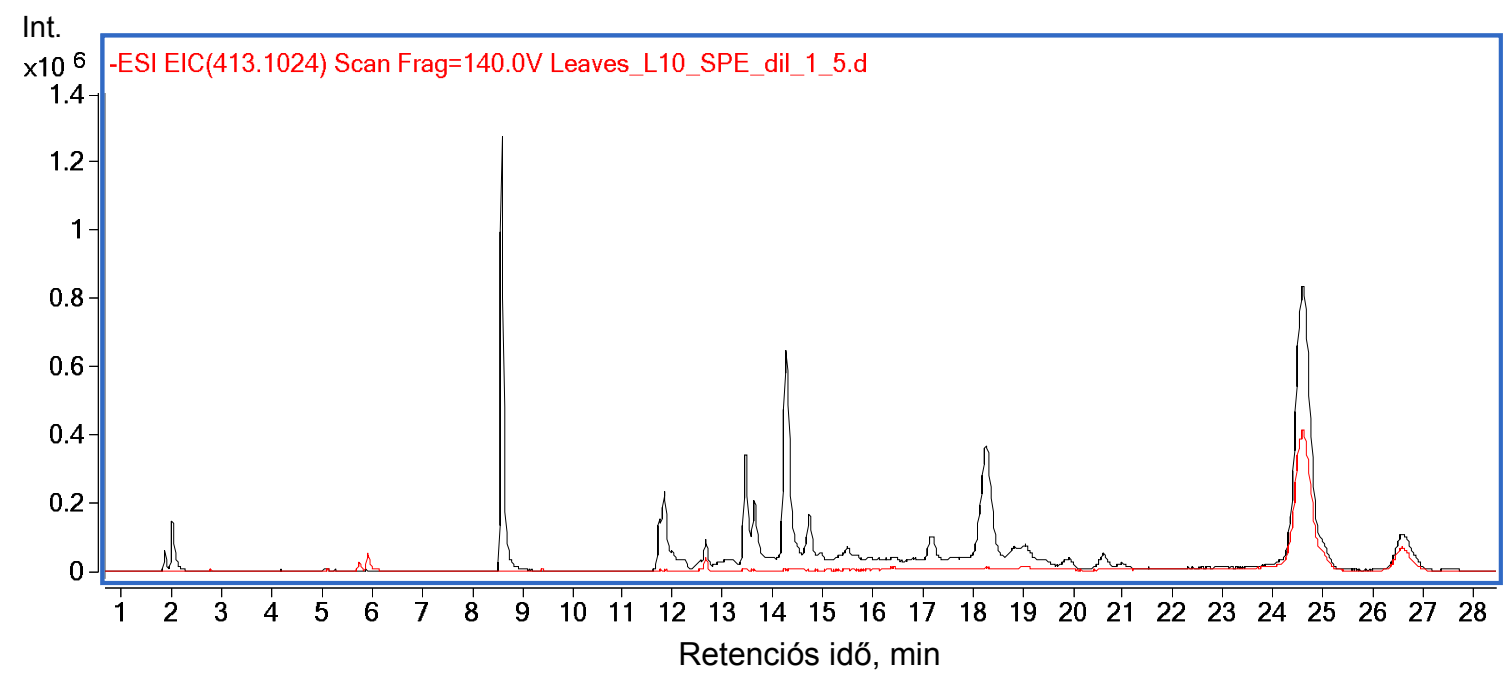

43. ábra: Olívalevélben lévő $\mathrm{m} / z$ 413,1024 (piros) és m/z 377,1242 (fekete) iontömegü komponensek kiemelt ionkromatogramjai 


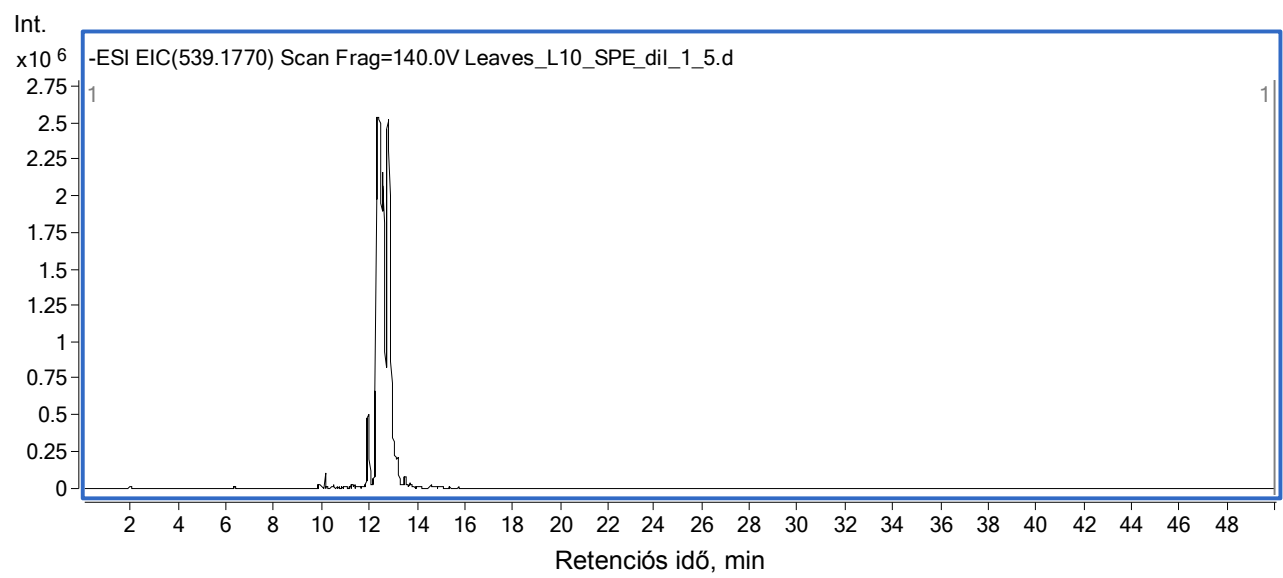

44. ábra: Az olívalevélben megtalálható oleuropein kiemelt ionkromatogramja (m/z 539,1770)

Az olívabogyó esetében is felvettem az $\mathrm{m} / \mathrm{z}$ 377,1242, az $\mathrm{m} / \mathrm{z} 413,1024$, az $\mathrm{m} / \mathrm{z} 409,1519$ és az $m / z$ 445,1286 iontömegü komponensek kiemelt ionkromatogramját. Az m/z 409,1519 iontömegü komponens nem jelent meg detektálható mennyiségben. Az $m / z$ 445,1286 iontömegü $\left(\left[\mathrm{M}+\mathrm{CH}_{4} \mathrm{O}+\mathrm{Cl}\right]^{-}\right)$komponens ugyanakkor négy retenciós időnél, 13,5, 13,7, 14,3 és 20,6 percnél mutatott kromatográfiás egyezőséget az m/z 377,1242 iontömegü aglikonnal. Ez - az olajokhoz hasonlóan - csak indirekt bizonyítékként szolgál az oleuropein aglikon $\left[\mathrm{M}+\mathrm{CH}_{4} \mathrm{O}-\mathrm{H}\right]^{-}$ származékának jelenlétére (45. ábra).

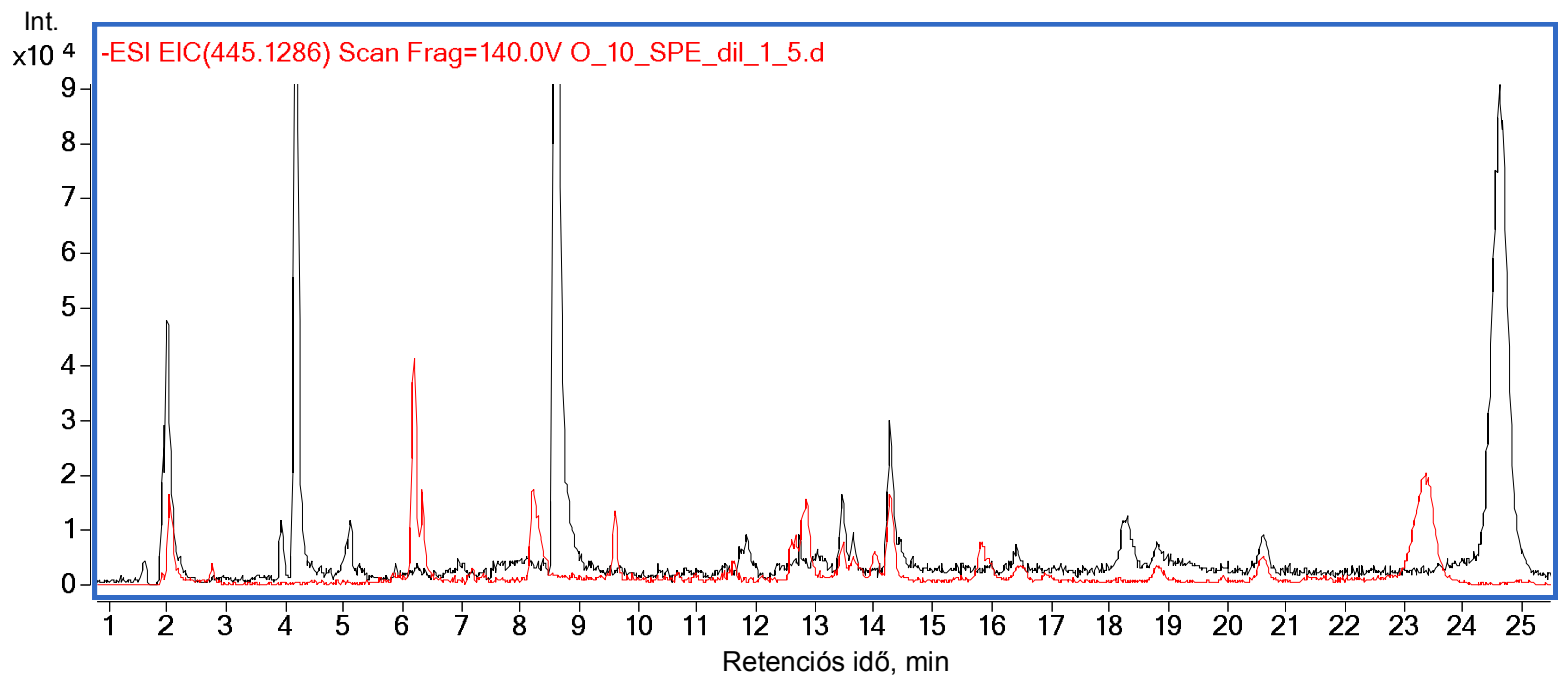

45. ábra: Az olívabogyóban található $m / z$ 445,1286 (piros) és $m / z$ 377,1242 (fekete) komponensek kiemelt ionkromatogramjai 
Az oleuropein aglikon klorid adduktja, az m/z 413,1024 iontömegü [M+Cl] komponens, hasonlóan az előző mintákhoz a 24,5 percnél, valamint a 26,6 percnél érkezik, az $\mathrm{m} / \mathrm{z}$ 377,1242 iontömegü komponens csúcsokkal együtt (46. ábra).

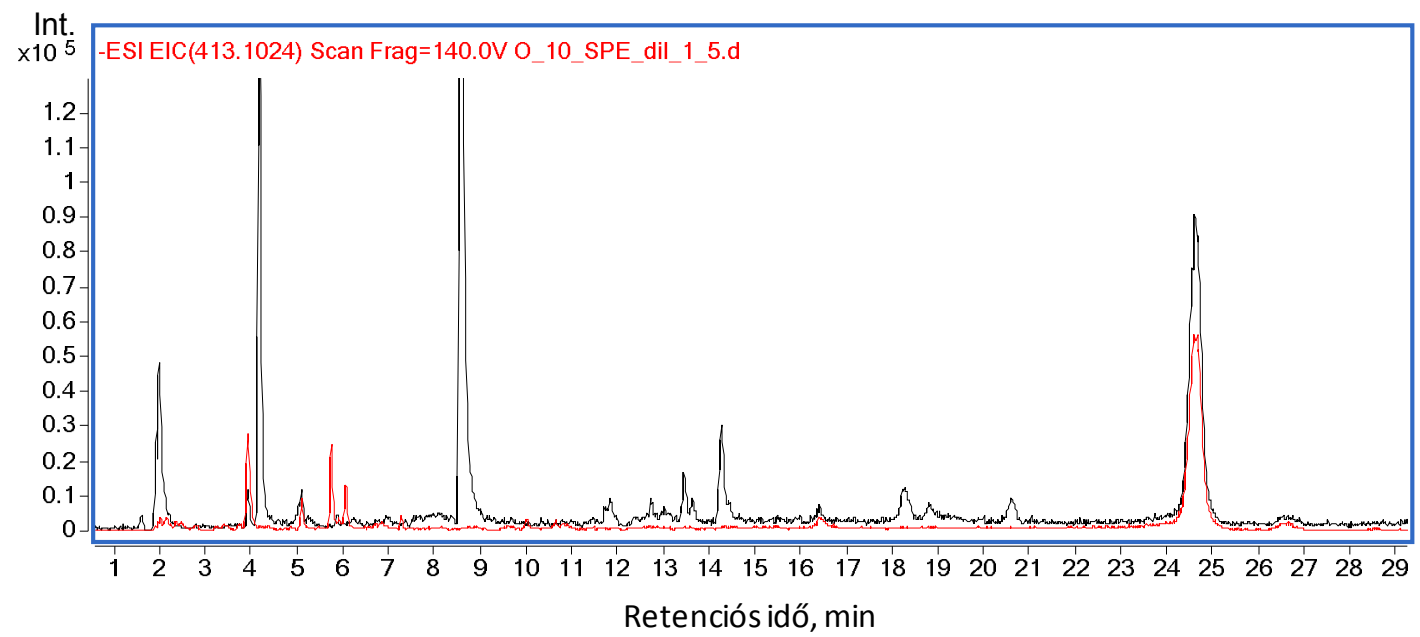

46. ábra: Az olívabogyóban található $m / z$ 413,1024 (piros) és m/z 377,1242 (fekete) komponensek kiemelt ionkromatogramjai

Az olívabogyóban szintén megtalálható volt az oleuropein komponens, melynek kiemelt ionkromatogramja $(\mathrm{m} / \mathrm{z} 539,1770)$ az 47. ábrán látható.

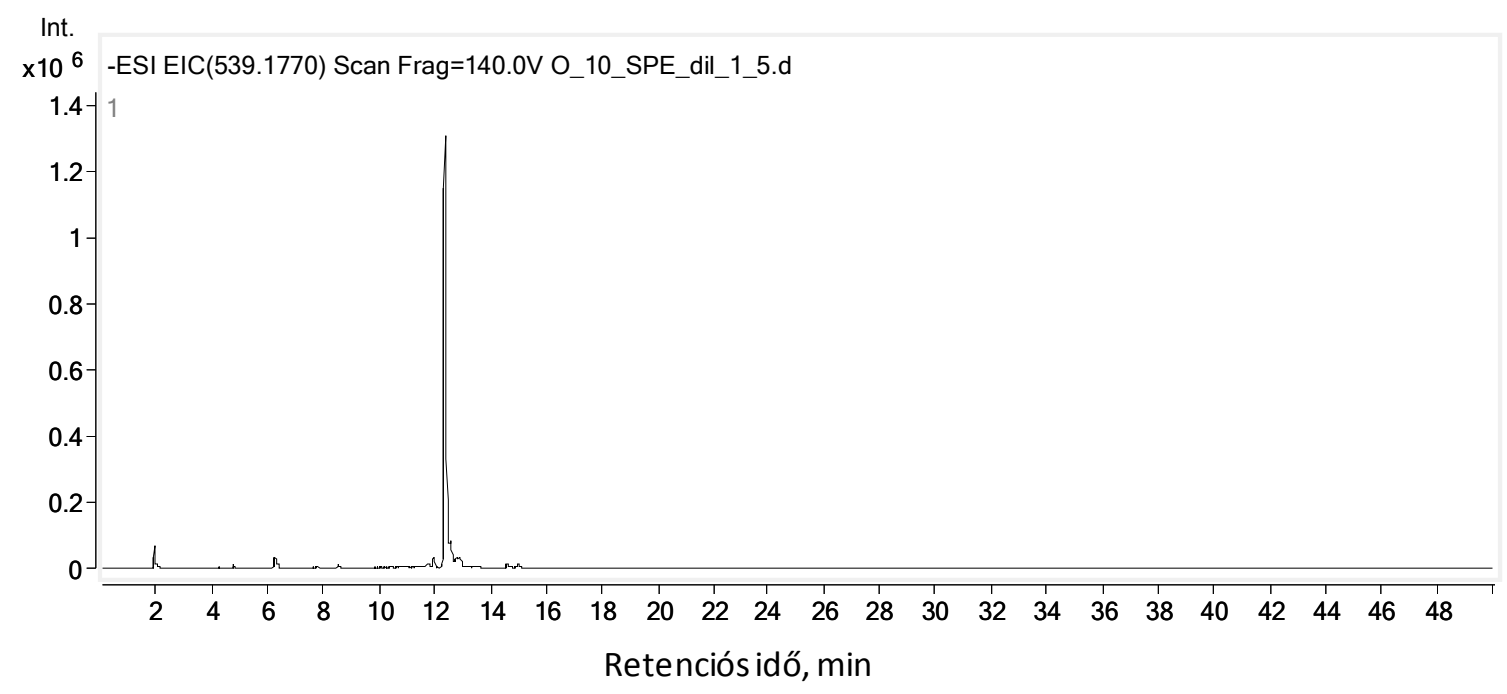

47. ábra: Az olívabogyóban található oleuropein kiemelt ionkromatogramja (m/z 539,1770).

Tehát az eredményekből az látszik, hogy az m/z 377,1242 iontömegü komponensnél nagyobb tömegü ionok közül az m/z 409,1519, [M+CH $\left.\mathrm{CH}_{4} \mathrm{O}-\mathrm{H}\right]^{-}$tekinthetö az oleuropein aglikonhoz tartozó származéknak, míg az m/z 413,1024 ion az oleuropein aglikon, az m/z 445,1286 ion pedig az előbb említett $\left[\mathrm{M}+\mathrm{CH}_{4} \mathrm{O}-\mathrm{H}\right]^{-}$származék klorid adduktjai. Megjegyzendő, hogy a levélnél és az olajnál 
nem volt kimutatható az $m / z$ 409,1519 ion, így azon csúcsok esetén ahol az m/z 377,1242 ionnal együtt csak az $m / z$ 445,1286 iontömegü ([M+CH $\left.4 \mathrm{O}+\mathrm{Cl}]^{-}\right)$komponens volt jelen, nem tudunk elégséges bizonyítékot adni az $\left[\mathrm{M}+\mathrm{CH}_{4} \mathrm{O}-\mathrm{H}\right]^{-}$származék meglétére. Azok az esetek, ahol a deprotonált ion(ok) és az intakt ion klorid adduktja egyaránt jelen vannak, kellő erejü bizonyítékot jelentenek az adott intakt komponens meglétére. Ugyanakkor, ha nagyon szigorúan tekintjük, akkor csak az olívabogyó és olívalevél esetében, a referencia standard segítségével egyértelmüen azonosított oleuropeinről állíthajuk egyedül, hogy az oleuropeinhez köthető származék, annak ellenére, hogy ebből a komponensből nem keletkezett az oleuropein aglikont jellemző $m / z$ 377,1242 iontömegü komponens.

Kísérletem kiindulópontja az volt, hogy Fu és mtsai 2009-es cikkükben azt a megállapítást teszik, hogy mivel az oleuropein aglikonból keletkező fragmensek, az m/z 377,1242 tömeghez tartozó csúcsok mindegyikénél adtak jelet, ezek a komponensek oleuropein aglikon izomerek lehetnek. Ezt az állítást vizsgálati eredményeimmel cáfoltam. A „bottom-up” azaz a lentről felfelé való építkezés elmélete és a kiértékelt kromatogramok alapján látható, hogy egyes izomernek vélt alkotók esetén, találhatóak nagyobb tömegek melyek igazolták, hogy a csúcsok egy része nem izomer. Ezek az alkotók vélhetően oleuropein aglikon-származékok. Eredményeim igazolták, hogy néhány oleuropein izomernek feltételezett alkotó $\mathrm{CH}_{4} \mathrm{O}$ molekularészlettel több, mint az eredeti aglikon. Ezek keletkezésével kapcsolatban nincs pontos információnk. Elképzelhető, hogy endogén komponensek, azaz az olíva érése, feldolgozása során kialakuló származékok. Ugyanakkor Karkoula es mtsai elméletét sem szabad figyelmen kívül hagyni, miszerint a minta-elökészítés során is keletkeznek mütermékek, melyek az oleuropein aglikon vizsgálatakor megjelenhetnek [KARKOULA et al., 2014]. További érdekességként - és az alkalmazott technika kritikájaként, az óvatosság jegyében - azt is érdemes megemlíteni, hogy amennyiben szükítjük a tömegablak szélességét, azaz növeljük a pontosságot, sem az oleuropein aglikont, sem a fölső tömegeket nem találjuk meg, ami a technika határait mutatja. Ha az értékelést a szoftver egy frissebb (B 06.00) verziójával is elvégezzük, akkor az általunk oleuropein aglikonként beazonosított $\mathrm{m} / \mathrm{z}$ 377,1242 tömegü komponens kiemelt ionkromatogramjának vizsgálatakor a program $\mathrm{C}_{21} \mathrm{H}_{22} \mathrm{~N}_{4} \mathrm{O}_{5}$ összegképletü molekulaként azonosította a legtöbb 377 Da tömegü komponenst a csúcsspektrumok alaján. Ez egyrész történhet a már említett technikai határok miatt, másrészt az is elképzelhető, hogy ezek a komponensek nem oleuropein komponensek, hanem olyan más, még ismeretlen molekulák, melyek az oleuropeinhez csupán nagyon hasonló tömegűek. Azonban ez utóbbi feltételezésnek a valószínüsége nem túl nagy, tekintettel a minta jellegére, hiszen az olívában található polifenolos komponensek egyik legjellemzőbb molekulája az oleuropein. 


\subsection{Izomer aglikonnal rendelkezöó flavonoid-glikokonjugátumok szelektív tömegspektrometriás vizsgálata}

A növényekben a polifenolok és ezen belül a flavonoidok döntő többsége glikokonjugátum formában van jelen. Ez azt jelenti, hogy egy adott flavonoid aglikon molekulához akár több különböző vagy azonos építőegység (szacharid, fenolsav) kapcsolódik. A kombinációs lehetőségeket bővíti, hogy azonos számú és azonos típusú építőkövek kapcsolódása esetén több pozicionális (pl.: 3-O-, vagy 7-O-) izomer is megjelenhet. A flavonoid glikokonjugátumok korszerü tömegspektrometriás vizsgálata során, e glikokonjugátumok azon tulajdonságát használjuk ki, hogy az építőegységek közötti kötések hasadásával létrejövő fragmensek eredményezik a legnagyobb gyakoriságú ionokat. Az így keletkező, ún. diagnosztikus ionok közötti tömegkülönbségekkel (semleges vesztésekkel) számolva jó megbízhatósággal megadható, hogy a vizsgált glikokonjugátumok glikán része milyen építőegységekből áll [CUYCKENS \& CLAEYS, 2004; VUKICS \& GUTTMAN, 2010]. A semleges vesztéseken alapuló szerkezetvizsgálati logikában, a „vesztési sor” végén található maga az aglikon molekula, amely a glikokonjugátum magját képezi. Ennek az ionnak a tömege alapján kapunk választ arra, hogy vesztések során lehasadó építőegységek milyen aglikon magra kapcsolódtak a vizsgálat tárgyát képező alkotó esetén. A módszer két típusú problémára azonban nem tud választ adni. Az egyik, hogy a lehasadó szacharidegységek térbeli szerkezete (pl.: glükóz, vagy galaktóz) nem megkülönböztethető, csupán általános formában adható meg az adott cukoregység (pl.: hexóz). Ugyan ebbe a problémába ütközünk a vesztési sor végén maradó aglikon mag esetén. Léteznek ugyanis összegképletben azonos (így pontos elméleti tömegben is azonos) aglikonok, melyek egymás szerkezeti izomerjeinek tekinthetők. Itt azonban nem térbeli izomériáról van szó, mint a példában is említett glükóz és galaktóz szacharid egységek esetében. Itt szerkezeti, vagy más néven konstitúciós izomerekről beszélünk. Tipikusan ilyen szerkezeti izomerpároknak tekinthetők a luteolin és a kaempferol páros, vagy az apigenin és a genisztein páros. További hasonló problémába ütközünk, amennyiben a tömegspektrométerrel pozitív ion módban vizsgálódunk és várható, hogy a minta antocianinokat is tartalmaz. Ennek okait egy konkrét példa segítségével mutatom be.

Összegképletük alapján például az izorhamnetin $\left(\mathrm{C}_{12} \mathrm{H}_{12} \mathrm{O}_{7}\right)$ és a petunidin $\left(\mathrm{C}_{16} \mathrm{H}_{13} \mathrm{O}_{7}\right)$ nem egyezik meg. Ugyanakkor a szokásosan alkalmazott savas kromatográfiás mobilfázisban a petunidin-származék (petunidin) aglikon része flavilium kation formában lesz jelen, melyet fragmentáció után, az MS készülék $\left[\mathrm{C}_{16} \mathrm{H}_{13} \mathrm{O}_{7}\right]^{+}$ionként képes detektálni. Az izorhamnetinszármazék viszont csak protonálódást követően válik láthatóvá a tömegspektrométer számra. A protonálódott izorhamnetin származékból lehasadó $\left[\mathrm{C}_{16} \mathrm{H}_{13} \mathrm{O}_{7}\right]^{+}$aglikon fragmens iontömege pedig 
pontosan meg fog egyezni a petunidin kation esetén mért immáron azonos összegképletü ion tömegével. A példánál maradva, amennyiben egy petunidin és egy izorhamnetin azonos építőkövekből álló glikokonjugátum formában van jelen a mintában, mind a semleges vesztések, mind a vesztési sor végén maradó aglikon iontömege azonos lesz [ABRANKÓ et al., 2012]. További ilyen izobár párosként említhető a kvercetin - delfinidin, illetve a kaempferol - luteolin izomerpároshoz, izobárként csatlakozó cianidin, valamint az apigenin - genisztein izomerpároshoz csatlakozó pelargonidin. Ez azt eredményezi, hogy izomer aglikonnal rendelkező flavonoid glikokonjugátumok az építőkövek semleges vesztései alapján még nagy tömegfelbontású készülékkel sem különböztethetőek meg. Ilyen esetben más módszerekhez kell folyamodni. Ezért célom volt egy olyan tömegspektrometriás módszer kidolgozása, mely megoldást nyújt erre a problémára.

A fejlesztés alapvető elve az volt, hogy a módszerben szelektív módon vizsgálni tudjuk az izomer aglikonokat. Ennek megvalósítása kézenfekvőnek tűnik az aglikon mag fragmentációját követő tömegspektrometriás vizsgálattal. Ezt persze csak abban az esetben tudjuk meghatározni, ha már nincsen rajta a glikán rész. Azért, hogy ezt a részt le tudjuk hasítani róla mielőtt az analizátorba érkezne, ionforrásban történő fragmentációt alkalmaztam. Az ionforrás fragmentáció sajátsága, hogy a fragmentációt nem előzi meg a (prekurzor) ion izolációja. Ennek előnye abban rejlik, hogy valódi MS/MS kísérletekkel ellentétben itt nem szükséges elöre tudni és előzetesen meghatározni annak az alkotónak az $\mathrm{m} / \mathrm{z}$ értékét, amelyiket fragmentálni kívánunk. Ez hihetetlen előnyt jelent olyankor, amikor ismeretlen alkotók profilozását végezzük. Ebben a tömegspektrometriás módszerben az ionforrás fragmentációt az 5.1-es fejezetben már részletesen ismertetett módszerrel azonos módon hajtottam végre. Mint azt már korábban írtam, flavonoid glikokonjugátumok tömegspektrometriás fragmentációja során, az építőegységek közötti kötések hasadásával létrejövő fragmensek eredményezik a legnagyobb gyakoriságú ionokat. Ezek közül a diagnosztikus ionok közül e módszerben kitüntetett jelentősége van az aglikon fragmensnek. (Ennek szokásos jelölése: $\mathrm{Y}_{0}$ ). Ezt az ionforrás fragmentációval előállított aglikon iont fragmentáljuk tovább annak érdekében, hogy vele kapcsolatban az azonosításhoz szükséges szerkezeti információkhoz jussunk. Ezt a fragmentációt immáron valódi MS/MS kísérletben, ütközési cella segítségével hajtjuk végre. (A folyamatot két eltérő kvercetinszármaték példáján szemlélteti a 48. ábra.) 


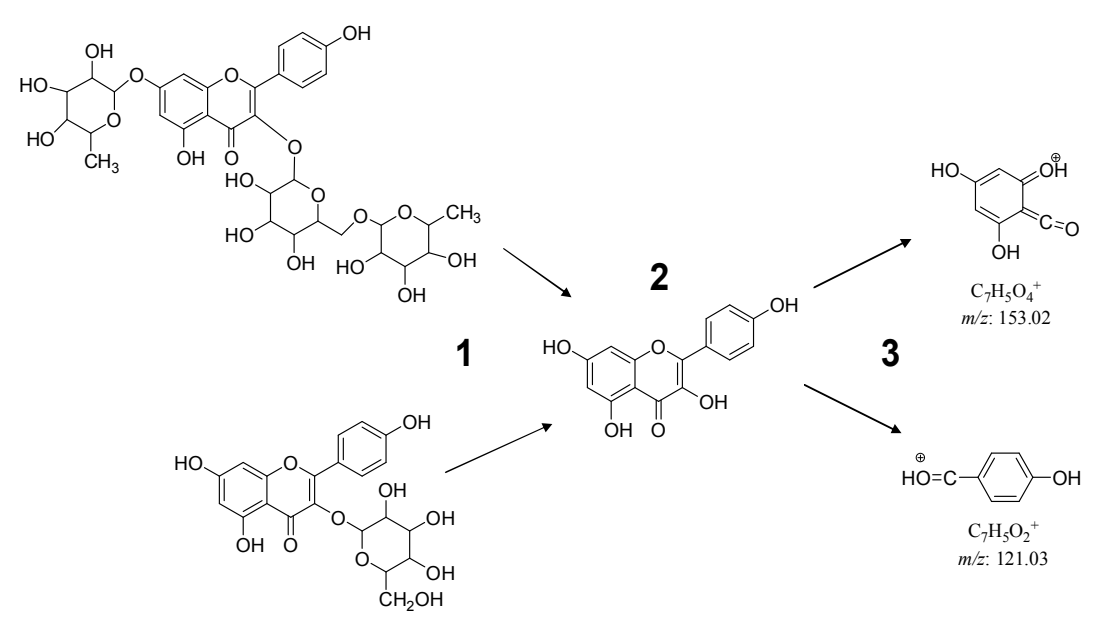

48. ábra: Az ionforrás fragmentáció bemutatása

1: a mintában jelen lévö konjugátumok (kaempferol-robinozid és kaempferol-3-O-glükozid),

2: Az ionforrás fragmentáció után keletkezö aglikon (kaempferol),

3: az MRM módszer során az aglikonból keletkezö jellemzö fragmensek (m/z 153, m/z 121)

A gyakorlatban egy MRM módszerrel a Q1 kvadrupól által kiválasztott aglikon ion (Y0) a Q2-es ütközési cellában újra fragmentálódik és a keletkező fragmensekből lehet azonosítani a molekulákat. Ilyenkor általános gyakorlati megközelítés, hogy a legnagyobb gyakoriságú termékionokat használjuk a molekulák MRM vizsgálata során. Mivel azonban esetünkben nagymértékben hasonló (szerkezeti izomer) aglikonmolekulákról van szó, a leggyakoribb fragmensek sokszor azonosak, ezért ez még nem nyújt megoldást a problémára.

Ahhoz, hogy szelektívebb meghatározást tegyünk lehetővé, további - lehetőleg csak az adott aglikonra jellemző - fragmenseket kell találni.

Kutatásom egyik célja az volt, hogy igazoljam a nagy hasonlóságot mutató szerkezeti izomernek tekinthető flavonoidok esetében is léteznek olyan ún. diszkrimináló képességgel rendelkező termékionok, melyek felhasználhatók az izomer aglikonok MRM módszerrel történő szelektív azonosítására.

A kísérletben vizsgált komponensek négy flavonoid családba tartoznak, melyek a következők: flavonolok, flavonok, antocianinok és izoflavonok. Illetve plusz egy komponens szerepel a módszerben a heszperetin, mely egy flavanon. Fontos megemlíteni, hogy a heszperetin egész értékre kerekítve, bár azonos tömegszámú, mint a kvercetin és delfinidin, mégsem izomerjei egymásnak. Ugyanakkor, a kvercetin és a heszperetin között meglévő $36 \mathrm{mDa}$ tömegkülönbséget alacsony felbontású HPLC-MS rendszerrel lehetetlen megkülönböztetni. A vizsgálatba bevont komponenseket az aglikonok molekulatömegei alapján három csoportba soroltam, melyek az $m / z 271, m / z 287$ és $m / z$ 303-as csoportok (lásd 49. ábra). 


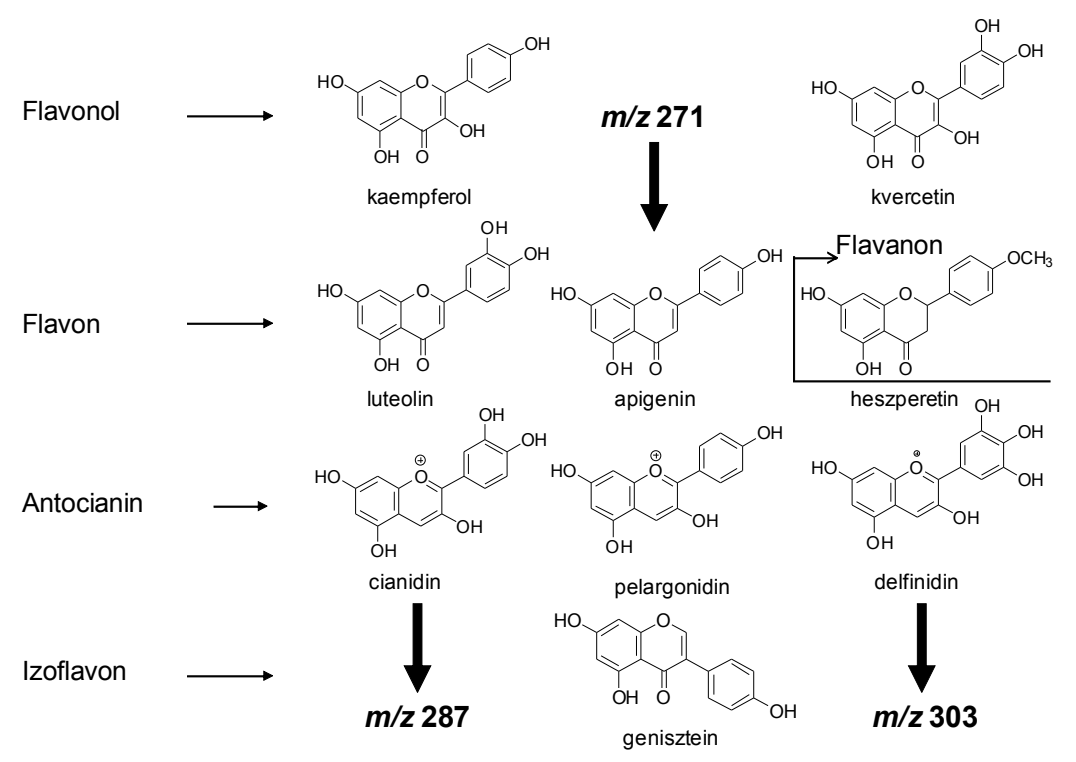

49. ábra: A módszerfejlesztéshez használt komponensek bemutatása és csoportositása

Minden aglikonnak felvettem a termékion spektrumát, majd azt vizsgáltam, hogy az azonos tömegszámú aglikonok esetében vannak-e olyan jellemző fragmensek, melyek alapján ezek egyértelmüen megkülönböztethetők. Az 1. mellékletben bemutatott három molekulacsoport termékion-spektrumainak vizsgálatából kitűnik, hogy kiválaszthatók olyan ionok, melyek alapján jó eséllyel szelektíven megkülönböztethetővé válnak a szerkezeti izomer aglikonok.

Ugyanakkor azt tapasztaltam, hogy mivel ezek a molekulák azonos tömeggel és hasonló szerkezettel rendelkeznek, a szokásos MRM módszerektől eltérően, több mint 2 fragmension kiválasztása szükséges, mert a két legjellemzőbb fragmension vizsgálata a megkülönböztetéshez nem elég szelektív. Ezért négy fragmensiont választottam ki mindegyik aglikonhoz, melyeket az 5. táblázat foglal össze.

5. táblázat: A vizsgált aglikonok kiválasztott fragmensei

\begin{tabular}{llllll}
{$[\mathbf{M + H}]^{+}$} & fr1 & fr2 & fr3 & fr4 & \\
\hline $\mathbf{3 0 3}$ & $\mathbf{1 5 3}$ & 137 & $\mathbf{8 9}$ & 229 & heszperetin \\
$\mathbf{3 0 3}$ & $\mathbf{1 5 3}$ & $\mathbf{1 3 7}$ & 89 & $\mathbf{2 2 9}$ & kvercetin \\
$\mathbf{3 0 3}$ & $\mathbf{1 5 3}$ & 137 & 89 & $\mathbf{2 2 9}$ & delfinidin \\
& & & & & \\
$\mathbf{2 8 7}$ & 153 & 135 & $\mathbf{1 3 7}$ & 213 & cianidin \\
$\mathbf{2 8 7}$ & $\mathbf{1 5 3}$ & $\mathbf{1 3 5}$ & 137 & 213 & luteolin \\
$\mathbf{2 8 7}$ & $\mathbf{1 5 3}$ & 135 & $\mathbf{1 3 7}$ & $\mathbf{2 1 3}$ & kaempferol \\
& & & & & \\
$\mathbf{2 7 1}$ & $\mathbf{1 2 1}$ & 153 & $\mathbf{2 1 5}$ & 141 & pelargonidin \\
$\mathbf{2 7 1}$ & 121 & $\mathbf{1 5 3}$ & $\mathbf{2 1 5}$ & 141 & genisztein \\
$\mathbf{2 7 1}$ & $\mathbf{1 2 1}$ & $\mathbf{1 5 3}$ & $\mathbf{2 1 5}$ & 141 & apigenin
\end{tabular}


Megjegyzendő, hogy még négy termékion kiválasztása sem eredményezi azt, hogy bizonyos fragmensek megléte/hiánya alapján az egyértelmü azonosítás lehetővé váljon. Vagyis még négy ion vizsgálata sem elegendő ahhoz, hogy az egyes ionokat az adott molekulára egyértelműen jellemző ún. kvalitatív, vagy megerősítő ionként kezeljünk és velük kapcsolatban egyszerű igen/nem (ún. bináris) ítéletek alapján döntsünk arról, hogy valójában melyik izomer aglikonnal van dolgunk. Ugyanakkor a spektrumokból az egyértelmüen látszik, hogy a négy vizsgált ion gyakoriságarányában jelentős mértékü eltérések tapasztalhatók. Azaz a megkülönböztetési folyamathoz, a vizsgált ionok gyakoriságarányát is felhasználva vélhetően sokkal jobban használható módszert kapunk. Mielőtt ennek részletes vizsgálatába kezdtem, előzetes vizsgálatokat végeztem arra vonatkozólag, hogy vajon van-e jelentős hatása a glikozid részeknek a fragmentumok keletkezési arányára. Ennek érdekében példaként három féle kaempferol molekulát vizsgáltam, melyek a következők voltak: kaempferol-glükozid, kaempferol-robinozid és maga az aglikon. Erre azért volt szükség, mert a kidolgozandó módszer eredeti célja, hogy flavonoid glikokonjugátumok vizsgálatára is alkalmas legyen. A kísérlet eredményeként kapott tömegspektrumokat az 50. ábrán mutatom be. 


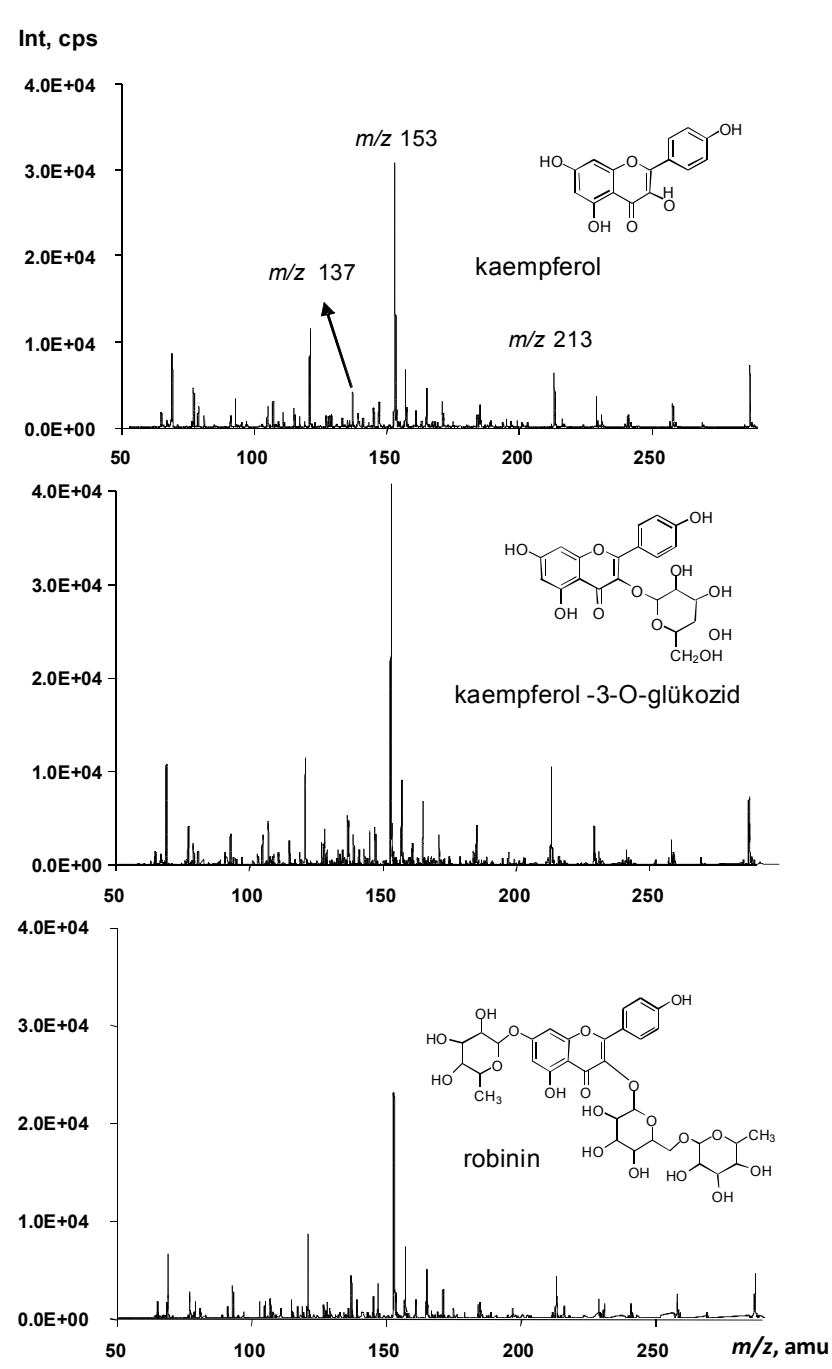

50. ábra: A kaempferol aglikonnak és glikozidos formáinak tömegspektruma

Ahogy láthatjuk a kaempferolt illetve glikozidjait meghatározó $m / z$ 137, $m / z 153$ és $m / z 213$ fragmensek mindhárom komponensből képződtek és egymáshoz viszonyított arányaik is hasonlónak tünnek. Így azt mondhatjuk, hogy a konjugátumoknak nincs jelentős hatása az aglikon ionforrásban történő fragmentációjára. Ahhoz azonban, hogy a gyakorlatban megbízhatóan alkalmazhassuk a módszert ennél meggyőzőbb bizonyítékora van szükség a gyakoriságarány adatok megbízhatósága kapcsán. Ezért a kiválasztott ionok gyakoriság-arányainak elemzését azzal folytattam, hogy immáron MRM módszerrel adatokat gyüjtöttem az gyakoriságarányok ismételhetőségéről. Arra voltam kíváncsi, milyen megbízhatóságúak ezek az adatok, vagyis alkalmasak lehetnek-e arra, hogy a gyakoriságarányokat felhasználva meg tudjam különböztetni az egyes izomer aglikonokat.

A kísérletekhez a vizsgált alkotókat tömegszámuk szerint három csoportba osztottam. Ez a következők miatt volt praktikus. A végleges módszert, az izomer aglikonokra szelektivitást 
biztosító MRM pásztázáson túl, prekurzorion pásztázással is ki kívántam egészíteni. Így a végleges módszer, az 5.1 fejezetben bemutatott módszerhez hasonlóan, alkalmas lesz arra, hogy ne csupán az aglikon magról, de a teljes glikokonjugátumról információt szolgáltasson. Amennyiben az MRM mérések mellé az MS módszerbe prekurzorion pásztázást is beszúrunk, akkor a mérés ciklusideje annyira megnő, hogy egy injektálásból csak egy aglikon csoport vizsgálatát teszi lehetővé. A tömegszámonkénti felosztás alkalmazása tehát azért volt praktikus már a módszerfejlesztés e szakaszában, mert a végleges módszer során szintén ezt a felosztást kívánom majd alkalmazni. Így a megbízhatósági vizsgálatokat ugyanazokkal a készülékparaméterekkel tudtam elvégezni, mint amelyeket a végleges módszer MRM kísérletében fogok alkalmazni.

Ennek megfelelően az iongyakoriság-arányok megbízhatóság vizsgálata során az $\mathrm{m} / \mathrm{z} 287$-es molekulacsoport tartalmazta a kaempferolt és három glikokonjugátumát (glükozid, rutinozid és robinozid), a luteolint és glükozidját, valamint a cianidint és glükozidját. Az $m / z$ 271-es molekulacsoport tartalmazta a geniszteint és glükozidját, az apigenint és glükozidját, valamint a pelargonidint és glükozidját. Végül az $\mathrm{m} / \mathrm{z} 303$ molekulacsoport tartalmazta a kvercetint és glükozidját, a heszperetint és glükozidját, valamint a delfinidint és glükozidját. A vizsgálatokat az antocianinokra nézve $10 \mu \mathrm{g} / \mathrm{ml}$, a többi komponensre nézve $5 \mu \mathrm{g} / \mathrm{ml}$ koncentrációjú standard oldatokkal 10 ismétlésben végeztem. A kromatográfiás elválasztás a 4.5. Kidolgozott kromatográfiás módszerek fejezetben részletezett módon történt. Az m/z 287-es molekulacsoport esetén kapott MRM kromatogramot, illetve az MRM területekből számolt arányokat az 51. és 52. ábrákon mutatom be.

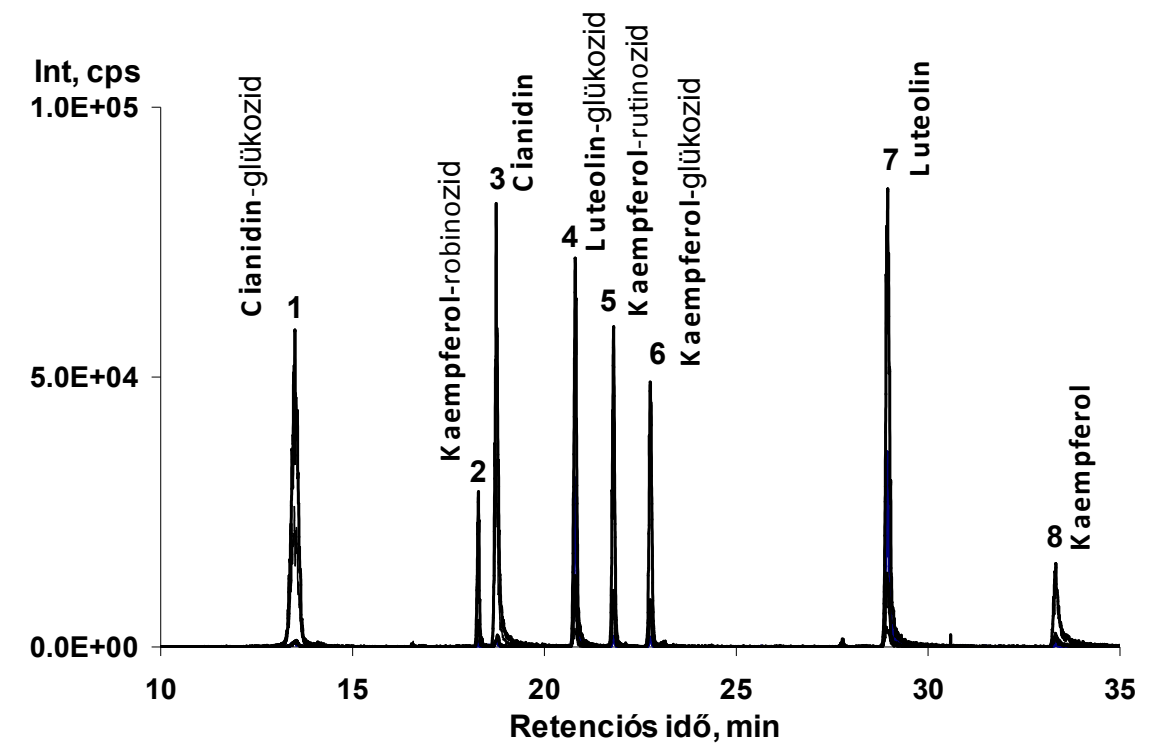

51. ábra: Az m/z 287 tömegü aglikonnal rendelkezö komponensek MRM kromatogramja 


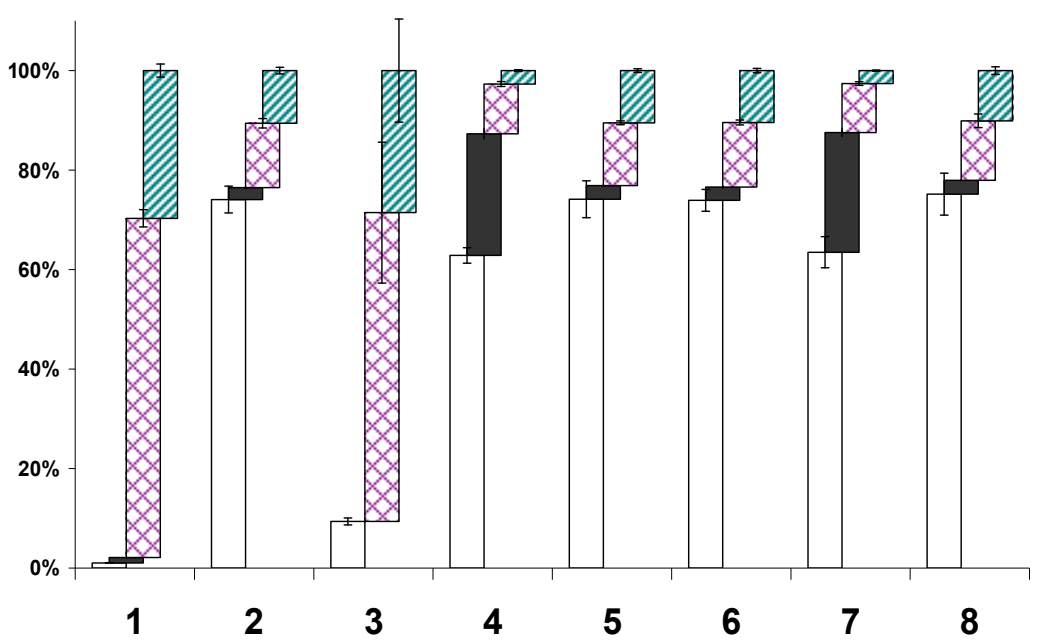

52. ábra: Az m/z 287 tömegü aglikonnal rendelkezö komponensek fragmensarányai

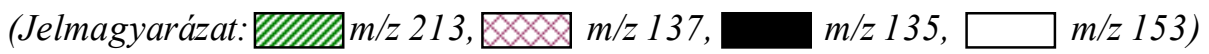

(Komponensek: 1: cianidin-glükozid, 2: kaempferol-robinozid, 3: cianidin, 4: luteolin-glükozid, 5: kaempferol-rutinozid, 6: kaempferol-glükozid, 7: luteolin, 8: kaempferol)

Cianidin esetén a négy vizsgált fragmens az alábbi arányokban jelent meg: $m / z \quad 137$ (62\% \pm 14\%), $m / z 153(9 \% \pm 1 \%), m / z 213(29 \% \pm 10 \%)$ és az $m / z 135$ nem volt detektálható. A cianidin glükozidnál az arányok a következők voltak: $m / z 137(68 \% \pm 1,7 \%), m / z 153(1 \% \pm 0,1 \%)$ és $m / z$ $213(30 \% \pm 1,3 \%)$ és $m / z 135(1 \% \pm 0,1 \%)$. A 137-es fragmens dominanciája és a 213-as fragmens 30\%-os arányú jelenléte jól jellemzi a cianidin aglikont.

Luteolin esetén jól megkülönböztethető értékeket kaptam. Itt a négy vizsgált fragmens gyakoriságarányai aglikon esetén az alábbiak voltak: $m / z 137(10 \% \pm 0,4 \%), m / z 153(63 \% \pm$ $3.1 \%), m / z 213(3 \% \pm 0,1 \%)$ és $135(24 \% \pm 0,8 \%)$. A luteolin glikozidos formája szintén azonos értékeket mutat. Az arányok ebben az esetben a következők: $m / z 137(10 \% \pm 0,5 \%), m / z 153(63 \%$ $\pm 1.6 \%), m / z 213(3 \% \pm 0,2 \%)$ és $m / z 135(24 \% \pm 1.1 \%)$. Luteolinra tehát jellemző, az $m / z 153$ fragmens és az $m / z 135$ ion markáns ( 25\%-os) jelenléte.

A kaempferol esetében, ahogy azt feljebb már láthattuk, az aglikon mellett három glikozidos formát (glükozid, rutinozid és robinozid) is vizsgáltam. Az aglikon esetén a vizsgált fragmensek az alábbi arányokat mutatták: $m / z 137(12 \% \pm 1.4 \%), m / z 153(75 \% \pm 4.2 \%), m / z 213(10 \% \pm 0,8 \%)$ és $m / z 135$ ( $3 \pm 0,1 \%)$. Ugyanebben a fragmentum sorrendben $(m / z 137,153,213$ és 135) a kaempferol-glükozidnál 13\% ( $\pm 0,5 \%), 74 \%( \pm 2.2 \%), 10 \%( \pm 0,4 \%)$ és $3 \%( \pm 0,3 \%)$ volt az arány. Kaempferol-rutinozidnál 13\% $( \pm 0,4 \%), 74 \%( \pm 3.7 \%), 10 \%( \pm 0,4 \%)$ és $3 \%( \pm 0,1 \%)$. Végül, a kaempferol-robinozidnál 13\% ( $\pm 1 \%), 74 \%( \pm 2,7 \%), 11 \%( \pm 0,7 \%)$ és $2 \%( \pm 0,2 \%)$ arányokat kaptam. Kaempferol esetén tehát elmondható, hogy a luteolinhoz hasonlóan domináns az 
$m / z 153$ ion, viszont emellett csupán 2-3\%-ban jelenik meg az m/z 135-ös ion. A kaempferol ezek alapján egyértelmüen megkülönböztethető a luteolintól.

Az m/z 271-es molekulacsoport esetén is elvégeztem ugyanezeket a vizsgálatokat. A kapott MRM kromatogramot, illetve az MRM területekből számolt arányokat az 53. és 54. ábrákon mutatom be.

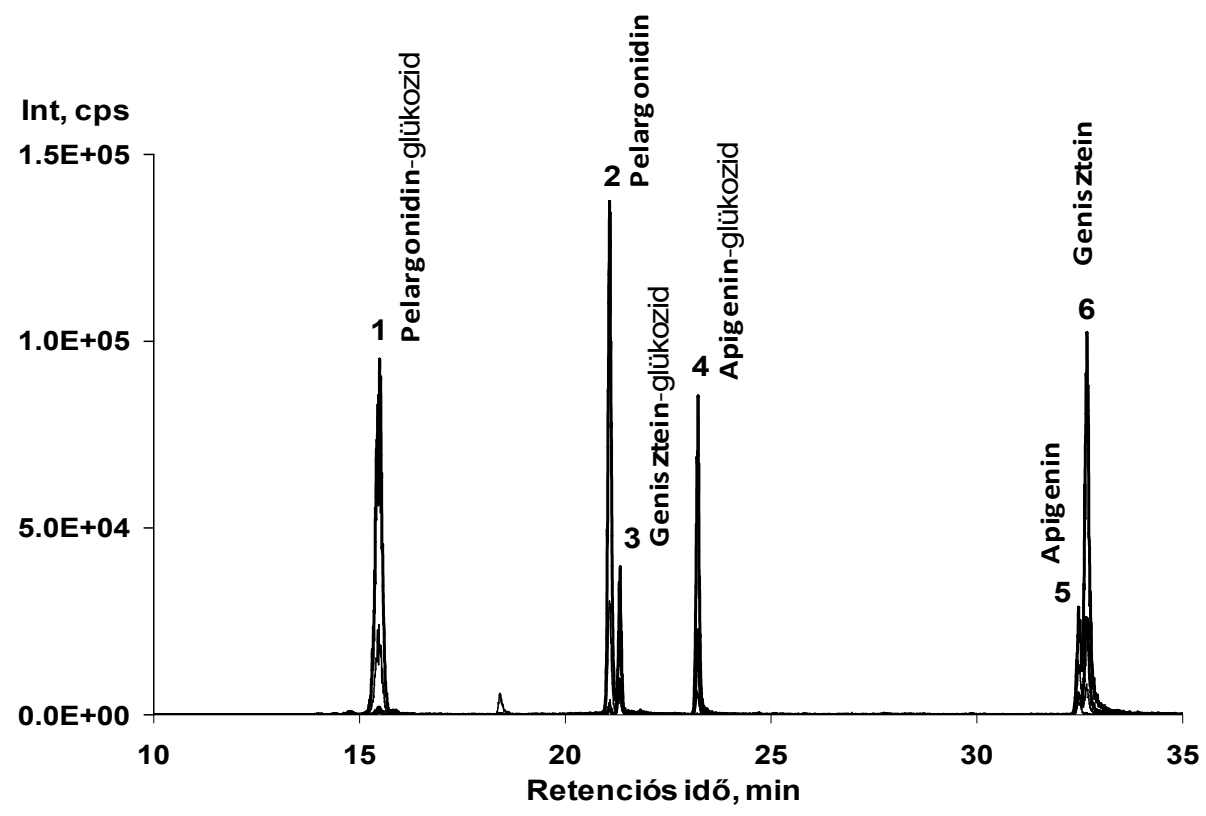

53. ábra: Az m/z 271 tömegü aglikonnal rendelkezö komponensek MRM kromatogramja

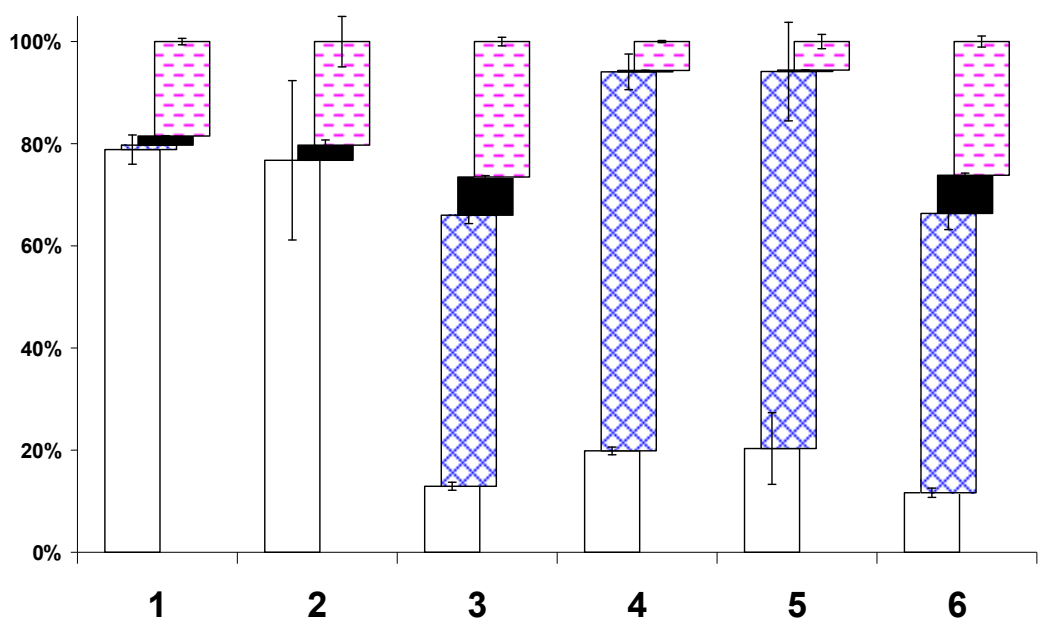

54. ábra: Az m/z 271 tömegü aglikonnal rendelkezö komponensek fragmensarányai (Jelmagyarázat: $\square \mathrm{m} / \mathrm{z} 121, \mathrm{O}_{---} \mathrm{m} / \mathrm{z} 141, \square \mathrm{m} / \mathrm{z} 153, \square \mathrm{m} / \mathrm{z} 215$ )

(Komponensek 1: pelargonidin-glükozid, 2: pelargonidin, 3: genisztein-glükozid, 4: apigenin-glükozid, 5: apigenin, 6: genisztein) 
Az adatok alapján megállapítható, hogy pelargonidin esetén a négy vizsgált fragmens $(\mathrm{m} / \mathrm{z}$ $121,141,215$ és 153$)$ rendre $77 \%( \pm 15,6 \%), 20 \%( \pm 4,9 \%), 3 \%( \pm 1 \%)$ és $m / z 153$ esetén $1 \%$ alatti gyakoriságarányban voltak jelen. A glikozidos formánál hasonló arányokat láthatunk ugyanezen fragmensek esetén. Számszerüsítve ezek a következők voltak: $m / z 121(79 \% \pm 2,9 \%)$, $m / z 141(18 \% \pm 0,6 \%), m / z 215(2 \% \pm 0,1 \%)$ és $m / z 153(1 \% \pm 0,1 \%)$. Pelargonidin esetén tehát megállapítható, hogy az $\mathrm{m} / \mathrm{z} 121$ ion a legnagyobb arányú, (mintegy 80\%-os) és 20\%-os arányban emellett jelen van az $m / z 241$ ion.

Genisztein esetében ugyanezen fragmensek arányai jelentősen eltértek. A genisztein aglikon vizsgálatakor az alábbi eredményeket kaptam: $m / z 121(12 \% \pm 0,9 \%), 141$ (26\% $\pm 1,1 \%), 215$ (7\% $\pm 0,4 \%)$ és $153(55 \% \pm 3,2 \%)$. A glikozid forma esetén az arányok pedig a következők voltak: $m / z$ $121(13 \pm 0,8 \%), 141(27 \% \pm 0,8 \%), 215(7 \% \pm 0,4 \%)$ és $153(53 \% \pm 1,6 \%)$. Látható, hogy genisztein esetén az $m / z 153$ a legmarkánsabban jelen lévő ion, aránya 53-55\% körüli. Az m/z 121 ion pedig kis gyakoriságarányú (12-13\%), ráadásul jelenléte kisebb (mintegy fele) az m/z 141 ion gyakoriságarányának (26-27\%).

Apigenin aglikon esetében a vizsgált fragmensarányok az alábbiak szerint alakultak: $m / z 121(20 \% \pm 7 \%), m / z 141(6 \% \pm 1,4 \%), m / z 215$ (nem detektálható) és $m / z 153(74 \% \pm 9,7 \%)$. Az apigenin-glikozidnak is hasonló eredményei születtek: $m / z 121(20 \% \pm 0,8 \%), m / z 141(6 \% \pm$ 0,2\%), $m / z 215$ (nem detektálható) és $m / z 153$ (74\% $\pm 3,5 \%$ ). Apigenin esetén - a geniszteinhez hasonlóan - az $m / z 153$ a legdominánsabb vizsgált termékion, ugyanakkor az apigenin geniszteintől való egyértelmű megkülönböztethetőségét az $\mathrm{m} / z 215$ ion vizsgálata biztosítja. Az apigenin esetén ugyanis ez nem detektálható, míg a geniszteinnél jól mérhető, 7\% körüli arányt mutatott. Szintén a genisztein-apigenin megkülönböztethetőséget szolgálja az m/z $153: m / z 141$ arány monitorozása. Genisztein esetén ez 2 körüli érték, míg apigenin esetében egyértelmüen 10 fölött van.

Az m/z 303-as molekulacsoporttal végzett vizsgálatok MRM kromatogramját, illetve az MRM területekből számolt arányokat az 55. és 56. ábrákon mutatom be. 


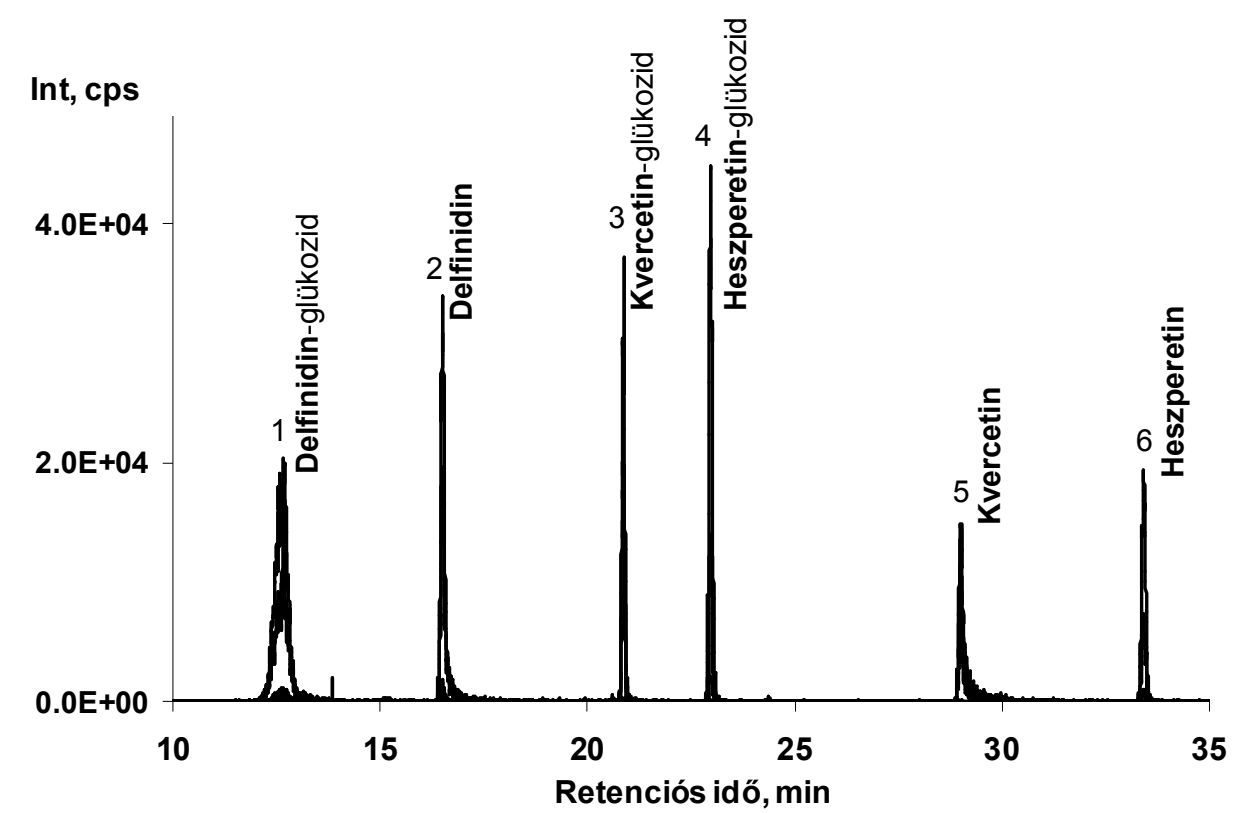

55. ábra: Az m/z 303 tömegü aglikonnal rendelkezö komponensek MRM kromatogramja

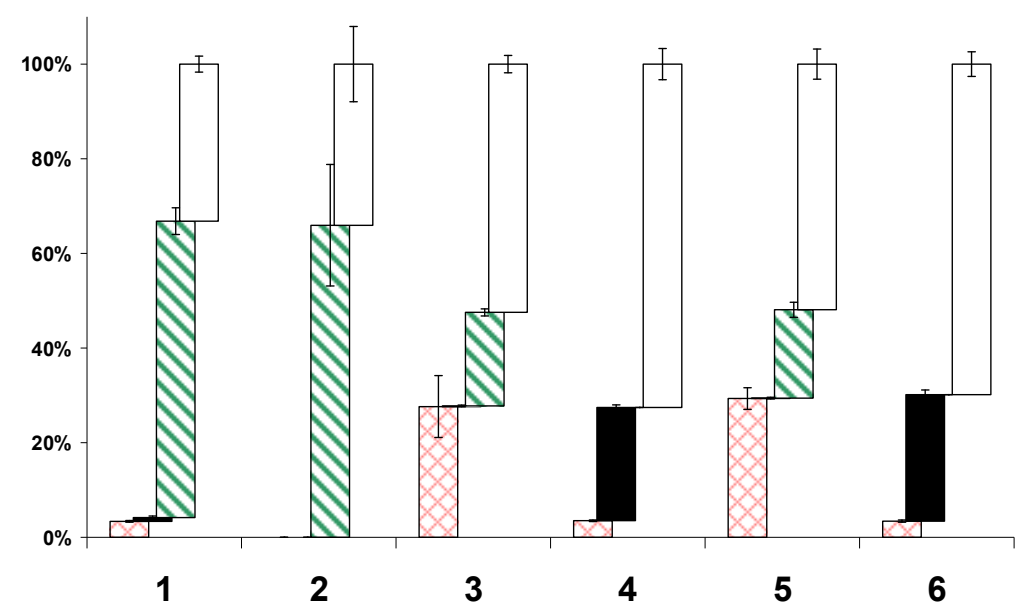

56. ábra: Az m/z 303 tömegü aglikonnal rendelkezö komponensek fragmensarányai (Jelmagyarázat: $\square \mathrm{m} / \mathrm{z}$ 153, $\square \mathrm{m} / \mathrm{z} 229$, $\square \mathrm{m} / \mathrm{z}$ 137, $\mathrm{m} / \mathrm{z} 89$

Komponensek: 1: delfinidin-glükozid, 2: delfinidin, 3: kvercetin-glükozid, 4: heszperetin-glükozid, 5: kvercetin, 6: heszperetin)

Delfinidin aglikon vizsgálatakor, az $m / z$ 229, 153, 137 és 89 gyakoriságarányok a következő eredményeket adták $m / z 229(66 \% \pm 12,8 \%), m / z 153(34 \% \pm 8 \%), m / z 137$ és $m / z 89$ nem volt detektálható. A delfinidin-glikozid hasonló arányokat mutat: $m / z 229(61 \% \pm 2,8 \%), m / z 153$ (33\% $\pm 1,7 \%), m / z 137(3 \% \pm 0,2 \%)$ és $m / z 89(1 \% \pm 0,4 \%)$. A glikozid esetén - bár kis arányban - de kimutatható volt az $m / z 137$ és az $m / z 89$ is. 
Kvercetin aglikonnál, ugyanazt a négy iont figyelembe véve az alábbi gyakoriságarányok adódtak: $m / z 229(19 \% \pm 1,6 \%), m / z 153(52 \% \pm 3,2 \%), m / z 137(29 \% \pm 2,3 \%)$ és $m / z 89$ nem volt detektálható. A kvercetin-glükozid fragmensei is közel azonos arányban kelekeztek, melyek a következők voltak: $m / z 229(20 \% \pm 0,7 \%), m / z 153(52 \% \pm 1,8 \%), m / z 137$ (28\% $\pm 6,5 \%)$ és $m / z 89$ nem volt detektálható.

A heszperetin aglikon esetében az $m / z 229$ (4\% $\pm 0,2 \%), m / z 153(70 \% \pm 2,6 \%), m / z 137$ (3\% $\pm 0,2 \%)$ és az $m / z 89(27 \% \pm 1 \%)$ gyakoriságarányok adódtak. Ezek az arányok a glikozidos forma vizsgálatakor is hasonlóak voltak: $m / z 229$ (nem volt detektálható), $m / z 153$ (73\% $\pm 3,3 \%$ ), $m / z 137$ $(4 \% \pm 0,2 \%)$ és $m / z 89(24 \% \pm 0,5 \%)$. A heszperetin esetében - hasonlóan a kvercetinhez - az $m / z$ 153 ion volt a legnagyobb gyakoriságarányú, ugyanakkor az $\mathrm{m} / z$ jelentős (24-27\%) arányú jelenléte egyértelmüen megkülönbözteti a heszperetint a kvercetintől. Hasonlóképpen, a 153/137 ionok aránya nagyságrendnyi eltérést mutat kvercetin $(\sim 2)$ és heszperetin $(\sim 20)$ esetében.

A gyakoriságarány mérések eredményeiről összefoglalva elmondható, hogy az általam aglikon izomer csoportonként kiválasztott négy jellemző fragmenssel, a vizsgált izomer aglikonok szelektíven azonosíthatóak. A kiválasztott fragmensek gyakoriságarányai megfelelő megbízhatósággal ismételhetők, az ismétlés bizonytalanságából eredő eltérések jelentősen kisebbek, mint az egyes aglikonok esetében diszkrimáló képességgel bíró gyakoriságarányokban tapasztalható eltérés. Az eredmények azt is igazolják, hogy az aglikonból és vizsgált glikozidokból származó aglikon ion fragmenseinek gyakoriságarányai nem mutatnak olyan jelentős eltérést, amely érdemben befolyásolná a többi izomertől való elkülönítést.

Az imént bemutatott, aglikoncsoportonként négy jellemző fragmens és azok gyakoriságarányainak vizsgálatán alapuló MRM módszer a végleges (teljes) módszernek csak egy részét képezi. E módszernél az aglikonok szelektív megkülönböztetése mellett - az 5.1 fejezetben bemutatott módszerhez hasonlóan- cél volt az is, hogy információt szolgáltasson arról, hogy milyen glikán rész kapcsolódik az adott aglikonhoz. Ezért az MS módszerben az „aglikon MRM” adatfelvételi kísérletet kiegészítettük egy, a korábbi módszerből átvett prekurzorion pásztázással is. Így az 5.1 fejezetben gyógynövények esetében alkalmazott flavonoid profilozó módszernek egy fejlettebb változatát hoztam létre. Ez a módszer egy adott aglikon esetén nagy megbízhatósággal és szelektivitással képes különbséget tenni izomer aglikonnal rendelkező flavonoid glikokonjugátumok között, mindemellett - a kiegészítő prekurzorion pásztázás segítségével információt szolgáltat arról, hogy az adott aglikonhoz milyen glikán rész kapcsolódott. 
A teljes módszer valódi mintákon való kipróbálásához házi fekete cseresznyét, kereskedelmi forgalomban kapható fagyasztott meggyet és az előző fejezetben bemutatott kakukk- illetve szurokfü mintákat használtam.

A házi fekete cseresznye esetében kapott MRM kromatogramot és fragmensarányokat a következő ábrákon láthatók, melyek közül az m/z 287-es aglikonnal rendelkezőket mutatnám be először. Ebből a csoportból három komponenst sikerült azonosítani, melyek kromatogramja és a keletkező fragmensek gyakoriságának aránya a 57. ill 58. ábrán láthatóak.

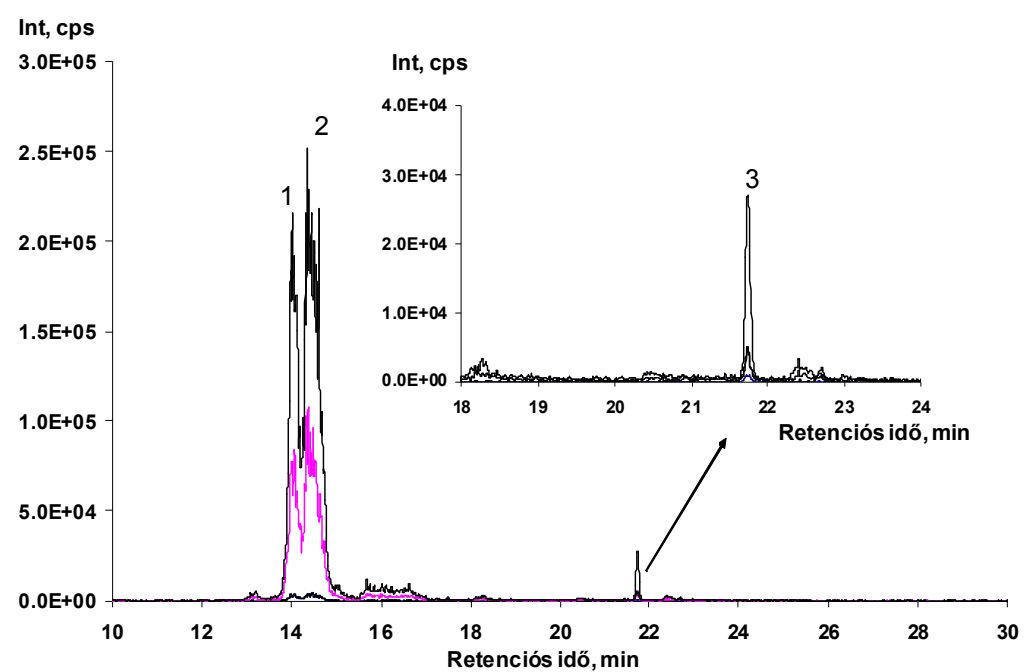

57. ábra: A házi fekete cseresznye mintában található, $m / z$ 287-es aglikonnal rendelkezö komponensek MRM kromatogramja

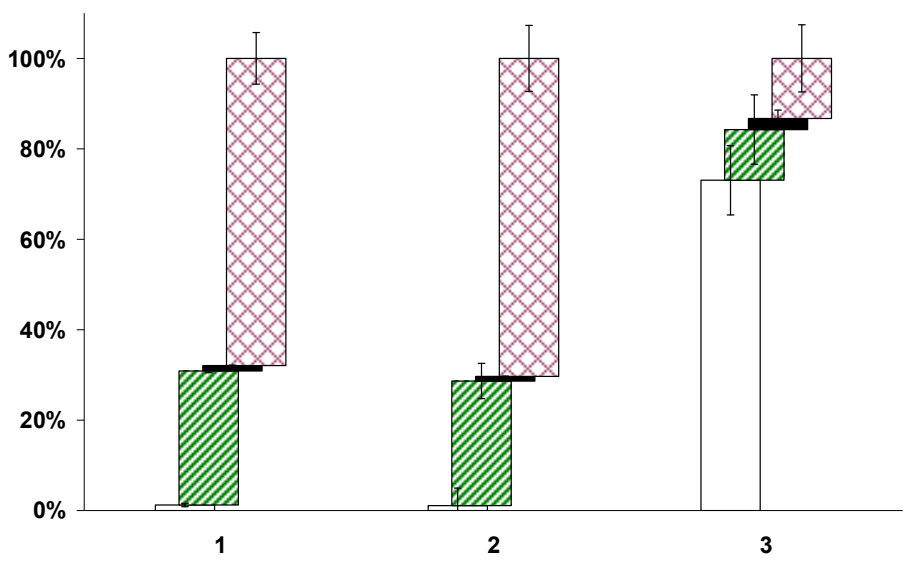

58. ábra: Az m/z 287 aglikonnal rendelkezö komponensek fragmensarányai a házi fekete cseresznye mintában

(Jelmagyarázat: $\mathbb{\mathbb { L }} \mathrm{m} / \mathrm{z} 213$, $\mathrm{m} / \mathrm{z} 137, \square \mathrm{m} / \mathrm{z} 135, \square \mathrm{m} / \mathrm{z} 153$ )

Ahogy az 58. ábrán bemutatott fragmens gyakoriságarányokból látszik, a három megtalált $m / z 287$ iontömegü aglikonfragmenssel bíró komponens közül kettő azonos aglikonnal rendelkezik. Az m/z 137-es fragmens az első komponens esetében 68\% a második komponens esetében 70\%- 
ban volt jelen, az m/z 213 fragmens pedig 30 illetve 28\%-ban keletkezett. Ezek az arányok arra utalnak, hogy ez a két komponens valamilyen cianidin származék lehet. A harmadik komponens esetében azt találtam, hogy a vizsgált ionok közül az m/z 153 fragmens keletkezett a legnagyobb arányban, 73\%-ban. Az m/z 137 és az m/z 213 fragmensek 13\% illetve 11\%-ban voltak jelen, míg az $m / z \quad 135$ csak 2\%-ban keletkezett. Ezen adatok alapján ezt a komponenst kaempferol származékként azonosítottam.

Az eredeti molekulák meghatározásának érdekében megvizsgáltam a prekurzorion pásztázással kapott tömegspektrumokat. Ennek eredményeit a 6. táblázat szemlélteti. Ezek alapján azt találtam, hogy az első komponens $\mathrm{m} / z$ 449 tömegszámmal rendelkezik, melyből arra következtetek, hogy a cianidin aglikonhoz egy hexóz kapcsolódott. A második komponens esetében $\mathrm{m} / \mathrm{z} 595$ tömegszámot kaptam, mely a cianidin aglikonhoz kötődött hexóz, illetve dezoxihexóz jelenlétére utal. A harmadik komponens esetében ismét $m / z 595$ tömegszámot találtam, mely itt is hexóz, illetve dezoxihexóz konjugátumok kaempferolhoz kapcsolódására utal. Itt azonban pontosabb meghatározásra is lehetőség nyílt, ugyanis a kísérletek során használt egyik kaempferol származék retenciós ideje megegyezett a 21,8 percnél érkező komponensével, így kijelenthető, hogy ez egy kaempferol-3-O-rutinozid.

6. táblázat: A házi fekete cseresznyében azonositott, m/z 287 iontömegü aglikonnal rendelkezö komponensek. (Jelölés: Hex: hexóz, dHex: dezoxihexóz.)

\begin{tabular}{lllll}
\hline Komponensek & $\begin{array}{l}\text { Retenciós } \\
\text { idö, } \text { min }\end{array}$ & Aglikon & Glikán rész & Konjugátum $\boldsymbol{m} / z$ értéke \\
\hline 1 & 14,5 & Cianidin & Hex & 449 \\
2 & 14,9 & $(m / z 287)$ & dHex-Hex & 595 \\
\hline 3 & 21,8 & $\begin{array}{l}\text { Kaempferol } \\
(m / z 287)\end{array}$ & 3-O-rutinozid & 595 \\
\hline
\end{tabular}

Az m/z 271 tömegszámú aglikonnal rendelkező molekulák közül két komponenst találtam, melyek MRM kromatogramja és a hozzájuk tartozó fragmensarányok az 59. ábrán láthatóak. Ahogy azt a diagram is jól szemlélteti, ez a két komponens azonos aglikonnal rendelkezik, mivel mindkét esetben gyakorlatilag megegyeznek a vizsgált ionok gyakoriságai. Az $m / z 121$ fragmens 78\%-ban, az $\mathrm{m} / \mathrm{z} 141$ fragmens 19\%-ban, az $\mathrm{m} / \mathrm{z} 215$ illetve az $\mathrm{m} / \mathrm{z} 153$ fragmensek pedig 2 illetve 1\%-ban keletkeztek mindkét komponensnél. Ezekből az eredményekből arra lehetett következtetni, hogy ezek pelargonidin származékok. 


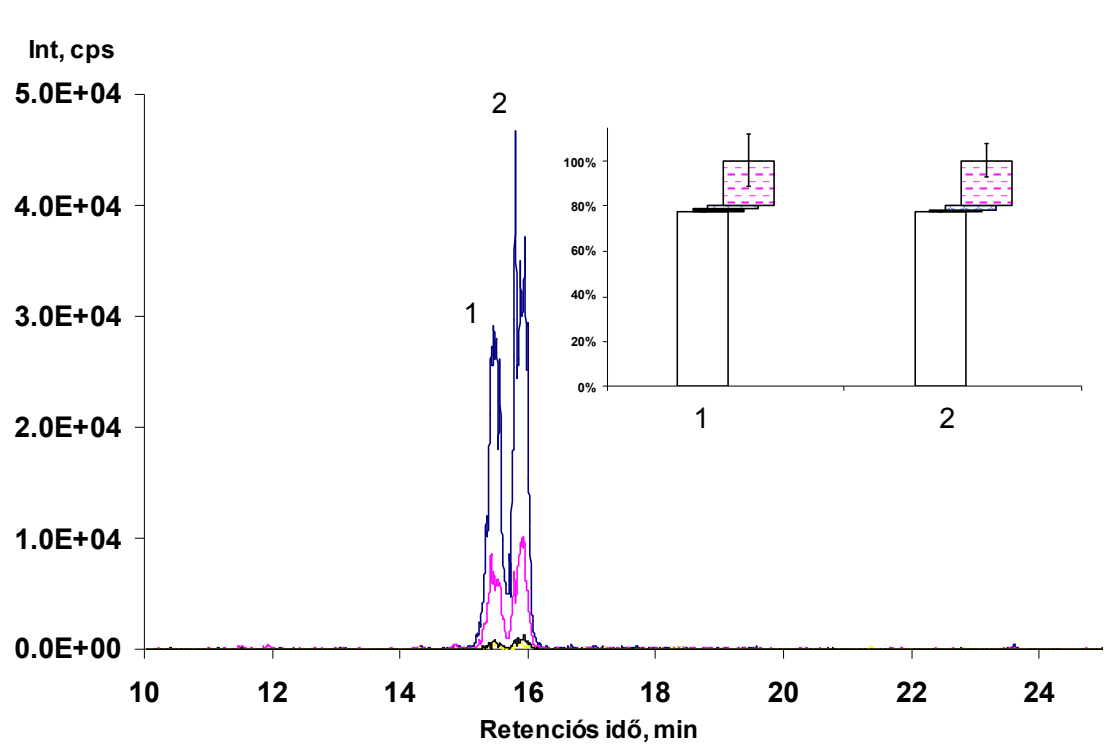

59. ábra: Az m/z 271 aglikonnal rendelkezö komponensek MRM kromatogramja és fragmensarányai a házi fekete cseresznye mintában

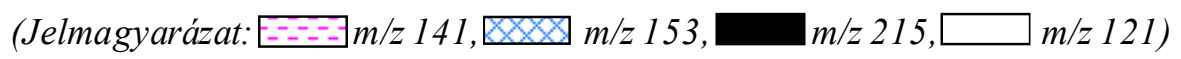

A prekurzorion módszer során sikerült az eredeti molekulák iontömegét meghatározni. Ezek a 7. táblázatban láthatóak. Az első komponens esetében ez $m / z 433$ volt, mely egy pelargonidinhexozid jelenlétére utal. A módszer kidolgozásakor használt standard retenciós idejével való egyezés miatt, pontosabb meghatározás is lehetséges, így ez a komponens valószínüsíthetően egy pelargonidin-3-O-glükozid, azaz egy callistephin. A második komponens iontömege $\mathrm{m} / \mathrm{z} 579$ volt, melyből feltételezhető, hogy ez egy pelargonidin-hexóz-dezoxihexóz konjugátum.

7. táblázat: A házi fekete cseresznyében azonositott, $\mathrm{m} / z 271$ iontömegü aglikonnal rendelkezö komponensek. (Jelölés: Hex: hexóz, dHex: dezoxihexóz.)

\begin{tabular}{lllll}
\hline Komponensek & $\begin{array}{l}\text { Retenciós idő, } \\
\text { min }\end{array}$ & Aglikon & Glikán rész & $\begin{array}{l}\text { Konjugátum } \\
\boldsymbol{m} / \boldsymbol{z} \text { értéke }\end{array}$ \\
\hline 1 & 15,5 & $\begin{array}{l}\text { Pelargonidin } \\
(\mathrm{m} / \mathrm{z} 271)\end{array}$ & $\begin{array}{l}3 \text { - } O \text {-glükozid } \\
\text { dHex-Hex }\end{array}$ & 433 \\
2 & 15,9 & & & 579 \\
\hline
\end{tabular}

Az m/z 303 tömegszámú aglikonnal rendelkező komponensek közül négy komponenst sikerült az MRM módszerrel meghatározni (60-61. ábra). A fragmensarányok alapján ezek a komponensek is azonos aglikonokkal rendelkeznek. Az $m / z \quad 153$ fragmens 47\%-50\%-ban, az $m / z 137$ fragmens 31-34\%, az $\mathrm{m} / \mathrm{z} 229$ fragmens 18-19\% gyakoriságarányt mutatott a négy komponens vizsgálatakor. A negyedik, $m / z 89$ fragmens értékelhető mennyiségben nem keletkezett. 
Ezek az adatok arra engednek következtetni, hogy ezek kvercetin aglikonnal rendelkező komponensek lehetnek.

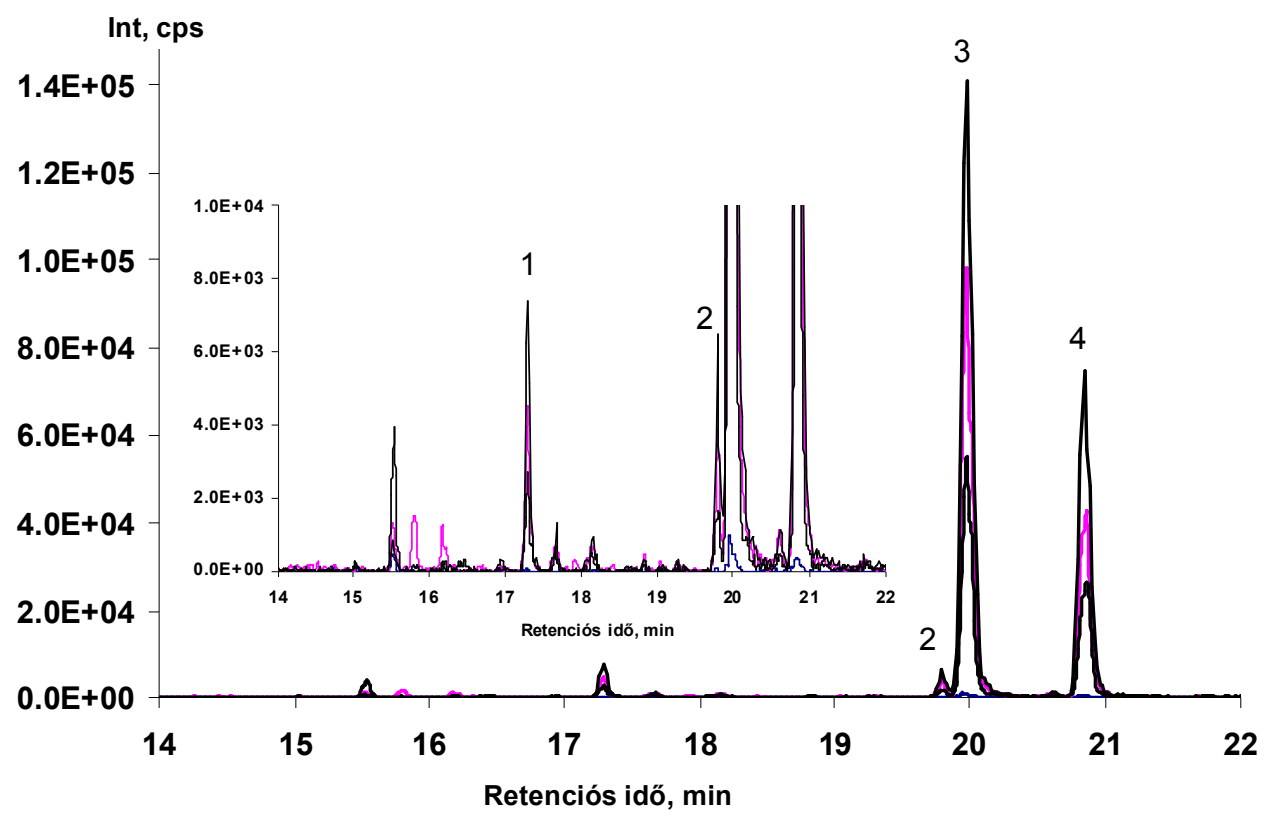

60. ábra: A házi fekete cseresznye mintában található, m/z 303-es aglikonnal rendelkezö komponensek MRM kromatogramja

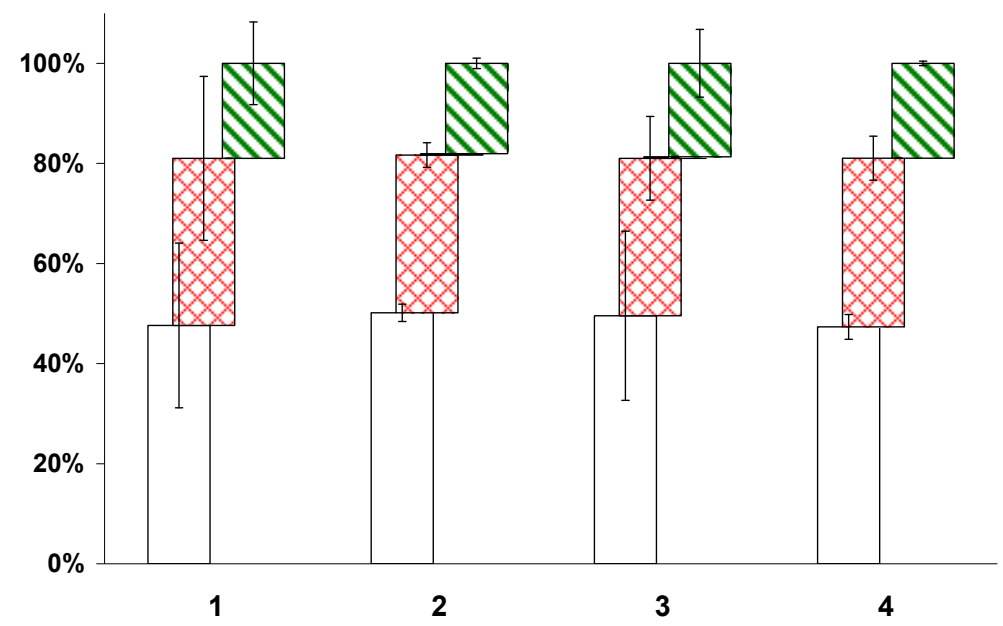

61. ábra: Az m/z 303 aglikonnal rendelkezö komponensek fragmensarányai a házi fekete cseresznye mintában

(Jelmagyarázat: $\mathrm{m} / \mathrm{m} / \mathrm{z} 229$, $\times \mathrm{m} / \mathrm{z}$ 137, $\mathrm{m} / \mathrm{z}$ 89, $\square \mathrm{m} / \mathrm{z}$ 153)

A prekurzorion módszer során kapott eredményeket a 8. táblázatban láthatjuk. A négy azonosított kvercetin származék közül az első, 17,4 percnél eluálódott komponens egy m/z 773 iontömegü kvercetin-dihexóz-dezoxihexóz volt, a második, 19,8 percnél detektált molekula egy $\mathrm{m} / \mathrm{z}$ 611 iontömeggel rendelkező származék, mely feltehetően egy kvercetin-hexóz-dezoxihexóz volt. A harmadik illetve negyedik komponens $m / z 465$ iontömegü volt, melyeket kvercetin-hexozidként 
azonosítottam. Ezek közül a 20,8 percnél eluálódó komponenst a módszer kifejlesztéshez használt standard retenciós ideje alapján kvercetin-3-O-glükozidként be tudtam azonosítani.

8. táblázat: A házi fekete cseresznyében azonositott m/z 303 iontömegü aglikonnal rendelkezö komponensek. (Jelölés: Hex: hexóz, dHex: dezoxihexóz)

\begin{tabular}{lllll}
\hline Komponensek & $\begin{array}{l}\text { Retenciós idő, } \\
\text { min }\end{array}$ & Aglikon & Glikán rész & $\begin{array}{l}\text { Konjugátum } \\
\boldsymbol{m} / \mathbf{z} \text { értéke }\end{array}$ \\
\hline 1 & 17,4 & & dHex-Hex-Hex & 773 \\
2 & 19,8 & Kvercetin & dHex-Hex & 611 \\
3 & 20,05 & $(m / z 303)$ & Hex & 465 \\
4 & 20,8 & & $3-O$-glükozid & 465 \\
\hline
\end{tabular}

A kidolgozott módszert egy kereskedelmi forgalomban kapható meggy mintán is kipróbáltam.

A vizsgált komponensek közül először az m/z 271-es aglikonnal rendelkező komponenseket vizsgáltam meg, melyek MRM kromatogramja a 62. ábrán látható. Ezen analitok közül ötöt tudtam meghatározni.

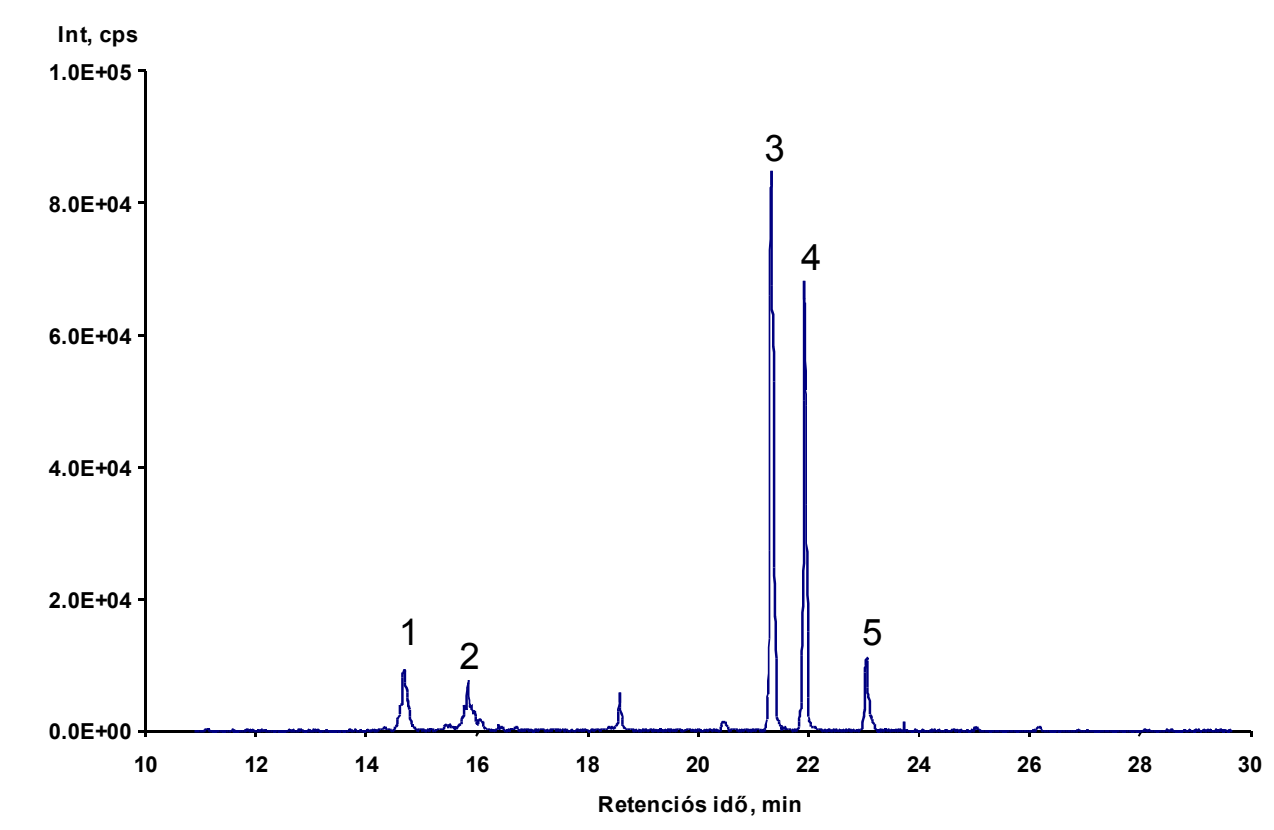

62. ábra: Kereskedelmi forgalomban kapható meggy m/z 271-es aglikonnal rendelkezö komponenseinek MRM kromatogramja

A 62. ábrán látható kromatogramon jelölt csúcsokhoz tartozó iongyakoriság-arányok az 63. ábrán láthatóak. Az első két komponens esetén a vizsgált ionok gyakoriságarányai hasonlóak. $\mathrm{Az} 1$. komponens esetében az $m / z 121$ ion 74\% $\pm 3 \%$-ban, az $m / z 141$ ion 25\% $\pm 3 \%$-ban volt jelen. A 2 . komponensnél $m / z 121$ 77\% \pm 10\%-ban, az $\mathrm{m} / \mathrm{z} 141$ 22\% \pm 5\%-ban volt jelen. A módszerrel 
vizsgált másik két fragmensből $(m / z 141$ és 153) az 1. és 2. komponensnél elhanyagolható mennyiséget mértem. Ezen arányok alapján az 1. és 2. komponens feltehetően egyaránt pelargodinin származék. A 3-5. komponensek esetében az arányok a következőképpen alakultak: az $\mathrm{m} / \mathrm{z} 153$-as fragmensei rendre 55\% ( $\pm 3 \%), 53 \%( \pm 8,9 \%), 52 \%( \pm 2 \%)$-ban voltak jelen, az $\mathrm{m} / \mathrm{z}$ 141-es fragmensek rendre 27\% ( $\pm 4 \%), 28 \%$ ( $\pm 2 \%), 27 \%$ ( $\pm 4 \%$ )-ban voltak detektálhatók, az $m / z$ 121-es fragmensek rendre 12\% $( \pm 3 \%), 11 \%( \pm 1 \%), 14 \%( \pm 1 \%)$-ban voltak megtalálhatóak. Az $m / z 215$ fragmens a 3. illetve 4. komponensnél 7\% ( \pm 1\%), az 5. komponens esetében 8\% ( \pm $1 \%$ ) arányban volt jelen. Ezek alapján azt a megállapítást tettem, hogy ezek a komponensek genisztein származékok lehetnek.

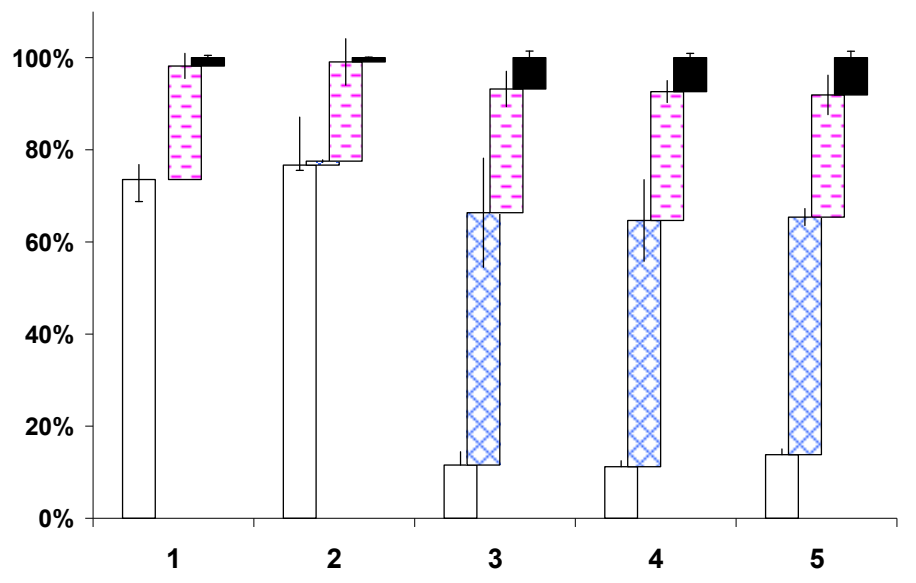

63. ábra: Az m/z 271 tömegü aglikonnal rendelkezö komponensek fragmensarányai a kereskedelmi forgalomban kapható fagyasztott meggy-mintában

$$
\text { (Jelmagyarázat: }=-\mathrm{m} / \mathrm{z} 141, \square \mathrm{m} / \mathrm{z} \text { 153, } \square / \mathrm{z} 215, \square \mathrm{m} / \mathrm{z} \text { 121) }
$$

Annak érdekében, hogy az eredeti molekulákat meg tudjam határozni, elemeztem a prekurzorion módszer során kapott tömegspektrumokat. Ennek eredményeképpen azt kaptam, hogy az első pelargonidin aglikonnal rendelkező komponens egy $m / z \quad 741$ tömegü molekula, mely feltehetően egy pelargonidin-dihexóz-dezoxihexóz. A második komponens eredeti tömege $\mathrm{m} / \mathrm{z} 579$ volt, melyet pelargonidin-dihexozidként azonosítottam. A harmadik, negyedik és ötödik komponens eredeti detektált formájának tömege $\mathrm{m} / \mathrm{z} 433$ volt, melyek valószínüsíthetően genisztein-hexozidok. Ezek közül a 3. komponens retenciós ideje megegyezett a módszer kifejlesztésénél használt genisztein-7-glükozid standard retenciós idejével, így erre pontosabb meghatározást is tudunk adni. Az összefoglaló adatokat a 9. táblázat foglalja magában. 
9. táblázat: A kereskedelmi forgalomban kapható meggy mintából azonositott, $\mathrm{m} / z 271$ aglikonnal rendelkezö flavonoid komponensek (jelölés: Hex: hexóz, dHex: dezoxihexóz)

\begin{tabular}{lllll}
\hline Komponensek & $\begin{array}{l}\text { Retenciós } \\
\text { idő, } \text { min }\end{array}$ & Aglikon & Glikán rész & $\begin{array}{l}\text { Konjugátum } \\
\boldsymbol{m} / \mathbf{z} \text { értéke }\end{array}$ \\
\hline 1 & 14,7 & Pelargonidin & dHex-Hex-Hex & 741 \\
2 & 15,8 & $(m / z$ 271) & dHex-Hex & 579 \\
\hline 3 & 21,3 & Genisztein & genisztein-7-O-glükozid & 433 \\
4 & 21,9 & $(m / z 271)$ & Hex & 433 \\
5 & 23,0 & & Hex & 433 \\
\hline
\end{tabular}

A következő vizsgált komponensek az $m / z$ 287-es iontömegü aglikonnal rendelkező molekulák voltak. Ezek közül 5 komponenst tudtam detektálni a módszerrel. Ezek MRM kromatogramja a 64. ábrán látható.

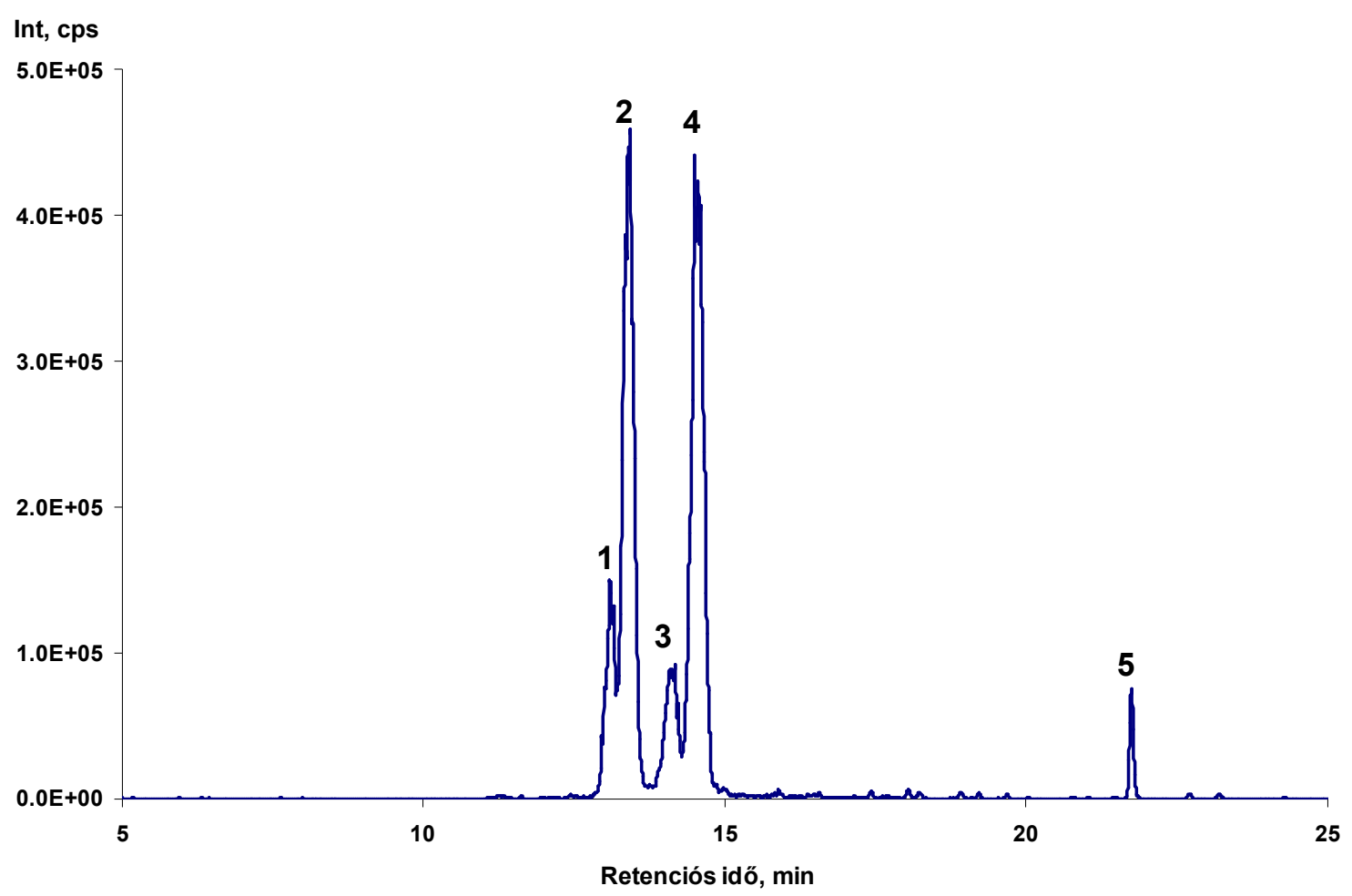

64. ábra: Kereskedelmi forgalomban kapható meggy-minta m/z 287-es aglikonnal rendelkezö komponenseinek MRM kromatogramja

A vizsgált fragmensek gyakoriságarányait a detektált komponensek esetén a 65 . ábra szemlélteti. Ahogy az látható, az 1 . komponens aglikonjának $m / z$ 137-es fragmense 73\% ( $\pm 15 \%$ ), az m/z 213 as fragmens pedig $25 \%( \pm 4 \%)$ arányban volt jelen. A módszerben megfigyelt másik két fragmens ( $m / z 135$ illetve $m / z$ 153) csak 1-1\%-ban voltak jelen. A 2-4. komponensek esetében hasonlóan 
alakultak az arányok. Az $m / z 137$ rendre 67\% ( $\pm 10 \%), 67 \%$ ( $\pm 9 \%), 68 \%$ ( $\pm 8 \%$ ) volt, míg az $m / z 213$ a 2-3. komponens esetében 30\% ( $\pm 4 \%$ ) volt, a 4 . komponens esetében $29 \%( \pm 5 \%)$ volt. A másik két fragmens $(m / z 135$ illetve $m / z$ 153) a 2-4. komponenseknél is elhanyagolható mennyiségben volt jelen. Ezek alapján az 1-4. komponensek valószínüsíthetően cianidin származékok. A 21,7 percnél eluálódó 5. komponens esetében az $\mathrm{m} / \mathrm{z} 153$ fragmens volt a legnagyobb arányú $(72 \% \pm 0,2 \%)$. Az $m / z$ in 137 ion $14 \% \pm 2 \%$ arányban, az $m / z 213$ ion 11\% $\pm 2 \%$ ban, míg az m/z 135-ös fragmens csak 3\% \pm 0,7\%-ban volt jelen. Az arányok azt mutatják, hogy az 5. komponens valószínüleg egy kaempferol származék.

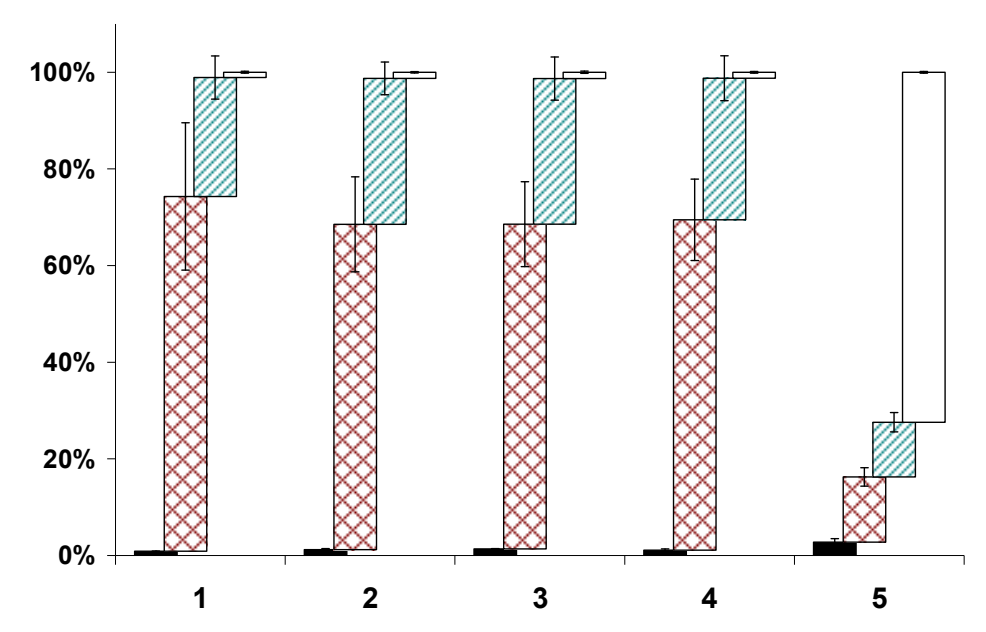

65. ábra: Az m/z 287 aglikonnal rendelkezö komponensek fragmensarányai a kereskedelmi forgalomban kapható fagyasztott meggy-mintában (Jelmagyarázat: $\mathbb{\mathbb { I }} m / z$ 213, $m / z$ 137, $\mathrm{m} / \mathrm{z} 135$, $m / z 153)$

A prekurzorion módszerrel kapott eredményeket megvizsgálva (10. táblázat) azt találtam, hogy az 1. komponens iontömege $\mathrm{m} / \mathrm{z} 757$ volt, mely megfeleltethető egy cianidin-dihexózdezoxihexóznak, ami megfelel az irodalomban a meggy egyik fö komponenseként emlegetett cianidin-3-glükozil-rutinozidnak [TOKUŞOĞLU \& HALL III, 2011]. A 2. komponens a vizsgálati eredmények alapján egy $\mathrm{m} / z 611$ iontömegű molekula, vélhetően egy cianidin-dihexozid volt. A 14,2 percnél eluálódó 3. komponens esetében a tömegspektrumban három ioncsúcs is jelen volt. A báziscsúcs az $m / z 727$ volt, mely feltehetően a cianidin aglikon egy pentózzal, egy hexózzal és egy dezoxihexózzal képzett konjugátumaként azonosítható. A második leggyakoribb iontömeg az $m / z \quad 449$ volt, mely egy cianidin-hexozidnak felel meg. Az m/z 595 ioncsúcs volt a tömegspektrumban a három lényeges ioncsúcs közül a legkisebb, mely valószínúsíthetően a cianidin aglikon egy hexózzal és egy dezoxihexózzal képzett származékaként azonosítható. Mivel ebben a tömegspektrumban három glikozidos származék is jelen van azonos retenciós időnél, valószínüsíthető, hogy csak az ionforrásban fragmentálódtak és az eredeti komponens az m/z 727 
volt, mely az irodalom alapján cianidin-3-O-xilozil-rutinozidra utalhat (66. ábra). Ezt a komponenst eddig meggyben nem, csak bogyós gyümölcsökben azonosították [TULIO et al., 2008]. A 4. komponens ismét $\mathrm{m} / z 595$ iontömeggel rendelkezett, mely szintén egy hexóz és egy dezoxihexóz kapcsolódására utal. Az utoljára eluálódó 5. komponens szintén $\mathrm{m} / \mathrm{z} 595$ iontömegü volt és retenciós ideje megegyezett a módszerfejlesztésben használt kaempferol-3-O-rutinozid standard retenciós idejével, így ezt a komponenst kaempferol-3-O-rutinozidként azonosítottam.<smiles></smiles>

66. ábra: A cianidin-3-O-xilozil-rutinozid szerkezeti képlete $\left(\mathrm{C}_{32} \mathrm{H}_{39} \mathrm{O}_{19}\right.$, molekulatömeg: $\left.727,641 \mathrm{~g} / \mathrm{mol}\right)$

10. táblázat: A kereskedelmi forgalomban kapható meggy mintából azonositott, $\mathrm{m} / \mathrm{z} 287$ aglikonnal rendelkezö flavonoid komponensek (jel.: Hex: hexóz, dHex: dezoxihexóz, Coum: kumarinsav, Pent: pentóz)

\begin{tabular}{|c|c|c|c|c|}
\hline Komp. & $\begin{array}{l}\text { Retenciós } \\
\text { idő, min }\end{array}$ & Aglikon & Glikán rész & Konjugátum $m / z$ értéke \\
\hline 1 & 13 & \multirow{4}{*}{$\begin{array}{l}\text { Cianidin } \\
(m / z 287)\end{array}$} & Hex-Hex-Coum /dHex-Hex-Hex & 757 \\
\hline 2 & 13,3 & & Hex-Hex & 611 \\
\hline 3 & 14,2 & & Hex / dHex-Hex/ Pent-dHex-Hex & $449 / 595 / 727$ \\
\hline 4 & 14,5 & & dHex-Hex & 595 \\
\hline 5 & 21,7 & $\begin{array}{l}\text { Kaempferol } \\
(\mathrm{m} / \mathrm{z} 287)\end{array}$ & 3-O-rutinozid & 595 \\
\hline
\end{tabular}

Végül az m/z 303 tömegszámmal rendelkező komponenseket vizsgáltam. Ebből a csoportból 6 komponenst tudott a módszer kimutatni. Ezek MRM kromatogramja a 67. ábrán látható. 


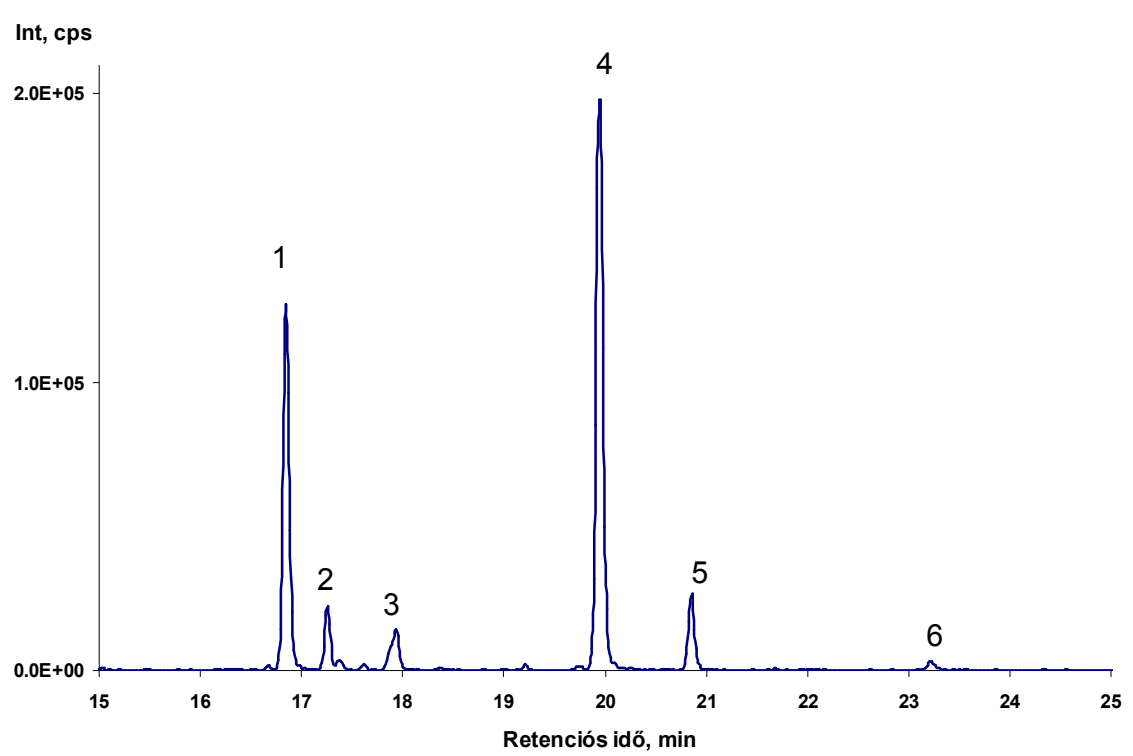

67. ábra: Kereskedelmi forgalomban kapható meggy-minta m/z 303-as iontömegü aglikonnal rendelkezö komponenseinek MRM kromatogramja

Megvizsgálva az MRM módszer során kapott fragmensek keletkezéseinek gyakoriságát, azt találtam, hogy ezek az értékek mind a hat komponens esetében nagyon egyezőek (68. ábra). Az $m / z 153$ fragmens a hat komponens esetében 46\% és 51\% között mozgott 2,2-8,7\% szórással. Az m/z 137 fragmens 31\%-ban volt jelen 0,1-6,5\% szórás értékekkel, kivéve a második komponenst, ahol $33 \pm 7.4 \%$ volt az elöfordulás gyakorisága. Az $m / z 229$ ion 18-22\%-ban fordult elö 1-2.6\% szórás értékekkel, míg az $m / z 89$ fragmens nem volt kimutatható. Az arányok alapján jól látszik, hogy ezek a komponensek kvercetin aglikonnal rendelkeznek.

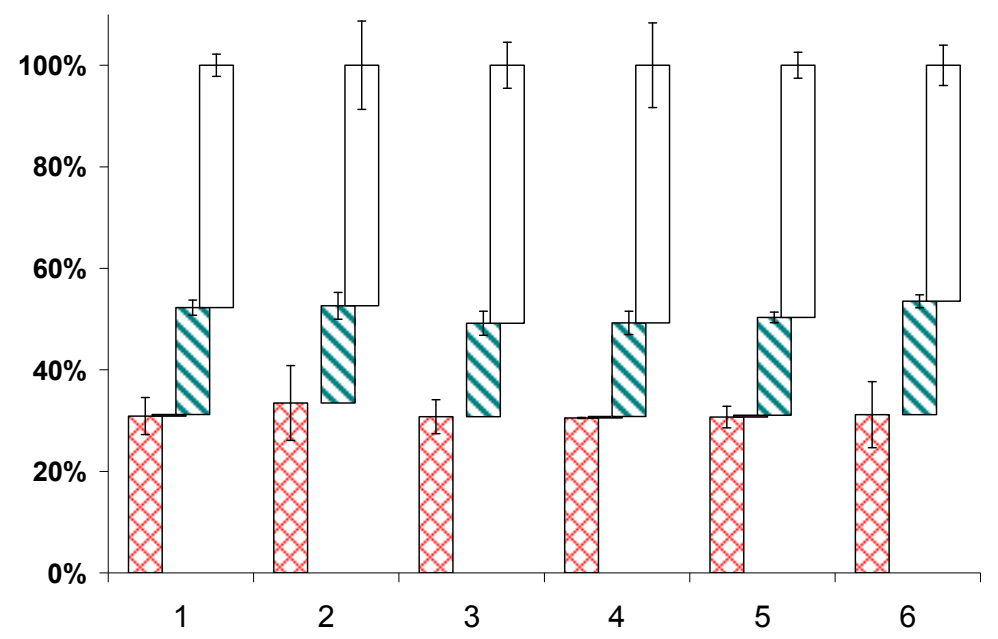

68. ábra: Az m/z 303 iontömegü aglikonnal rendelkezö komponensek fragmensarányai a kereskedelmi forgalomban kapható fagyasztott meggy-mintában

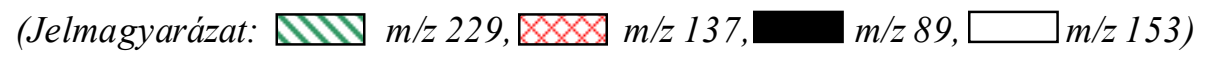


Az MRM módszert követő prekurzorion módszer alapján kapott eredményeket a 11 . táblázat mutatja. Ahogy azt láthatjuk, az 1-2. komponens $m / z 773$ iontömeggel rendelkezik, melyek feltehetően kvercetin-dihexóz-dezoxihexózok. A 2-4. komponensek iontömegei egyarán $m / z 611$ voltak, mely kvercetin-hexóz-dezoxihexóznak felel meg. Az 5-6. komponensek iontömege m/z 465 volt, melyet kvercetin-hexozidként lehet azonosítani. Ezek közül a 20,8 percnél eluálódó 4. komponenst, a módszer kifejlesztéséhez használt standard retenciós ideje alapján kvercetin-3-Oglükozidként tudtam beazonosítani.

11. táblázat: a kereskedelmi forgalomban található meggyben található 303-as iontömegü aglikonnal rendelkezö komponensek (Jelölés: Hex: hexóz, dHex: dezoxihexóz.)

\begin{tabular}{lllll}
\hline Komp. & Idő, min & Aglikon & Konjugátum & $\begin{array}{l}\text { Eredeti molekula } \\
\boldsymbol{m} / \boldsymbol{z} \text { értéke }\end{array}$ \\
\hline 1 & 16,8 & & dHex-Hex-Hex & 773 \\
2 & 17,2 & & dHex-Hex-Hex & 773 \\
3 & 17,9 & Kvercetin $(m / z 303)$ & dHex-Hex & 611 \\
4 & 19,9 & & dHex-Hex & 611 \\
5 & 20,8 & & $3-O$-glükozid & 465 \\
6 & 23,2 & & Hex & 465 \\
\hline
\end{tabular}

Ezt a módszert az 5.1-es fejezetben vizsgált gyógynövények esetében is kipróbáltam. Először a kakukkfü minta vizsgálati eredményeit mutatnám be. Ebben a mintában az $\mathrm{m} / \mathrm{z} 271$-es iontömegü aglikonnal rendelkező molekulák közül csak egyetlen komponens volt kimutatható. Az MRM vizsgálat során kapott fragmensek arányai azt mutatták, hogy az m/z 153 rész 78\%-ban, az m/z 121 17\%-ban, az m/z 141 pedig 5\%-ban volt jelen, míg $\mathrm{m} / \mathrm{z} 215$ nem keletkezett. Ezek az arányok az apigenin aglikont jellemzik. Az MRM vizsgálat után kapott kromatogram illetve fragmensarány a 69. ábrán látható. 


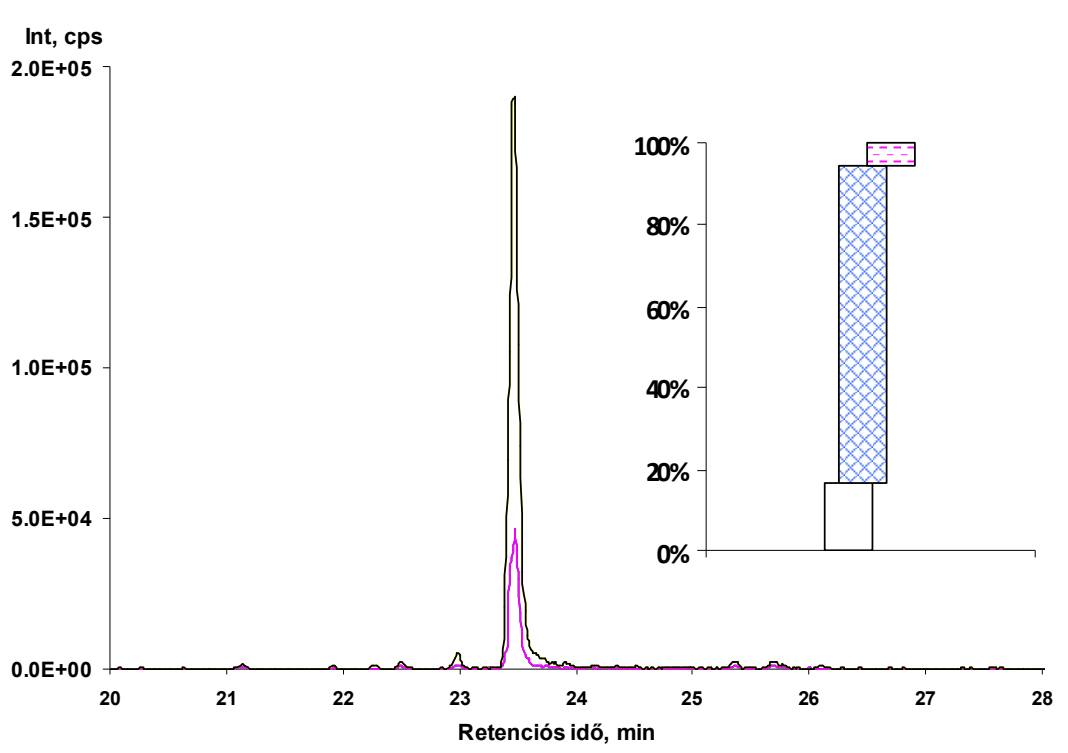

69. ábra: A kakukkfü minta m/z 271 tömegü aglikonnal rendelkezö komponens MRM kromatogramja illetve, fragmensarányai

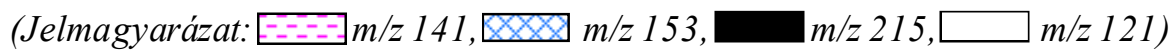

A prekurzorion módszerrel való vizsgálat után azt kaptam, hogy ez a komponens egy $m / z 447$ tömegszámmal rendelkező alkotó, mely feltehetően az apigenin egy hexozilsavval képzett származéka.

Az m/z 287 tömegszámú aglikonnal rendelkező komponensek vizsgálatakor két nagy csúcsot adó (1. és 2. jelölésű komponensek) és több kisebb (a kromatogramon nem jelölt) komponenst találtam. Ezek MRM kromatogramja és fragmensarányai az 70. ábrán láthatóak. Itt az látszik, hogy a négy vizsgált fragmens közül az $m / z 153$ fragmens az 1-2. komponensek esetében 60\%-ban keletkezett, az $m / z 135$ pedig az 1. komponens esetében 29\%-ban, a 2. komponens esetében 25\%-ban keletkezett. A másik két fragmens keletkezési aránya kisebb volt. Az m/z 137 az 1. komponens esetében 8\%-ban, a 2. esetében 11\%-ban keletkezett, míg az $\mathrm{m} / \mathrm{z} 213$ ion 2-3\%-ban volt jelen az 1-2. komponenseknél. Ezek az arányok luteolin aglikonnal rendelkező molekulákra utalnak. 


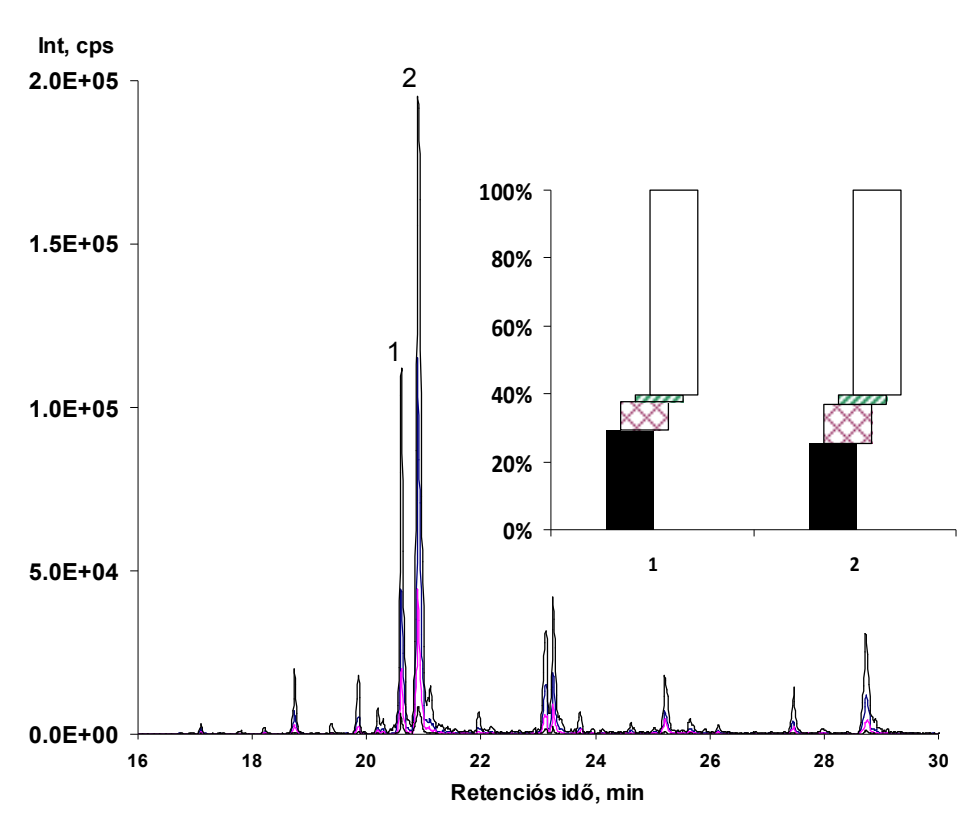

70. ábra: A kakukkfü minta m/z 287 iontömegü aglikonnal rendelkezö komponenseinek MRM kromatogramja illetve fragmensarányai

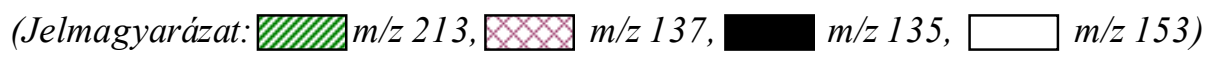

A prekurzorion módszer során kapott adatokból sikerült megtudni e két komponens eredeti iontömegét, mely az 1. komponens esetében $m / z 449$ volt, mely egy luteolin-hexozidra utal, a 2. komponens pedig $\mathrm{m} / \mathrm{z} 463$ iontömegü volt, ami egy luteolin hexozilsavval (vélhetően glükuronsavval) képzett származéka. A módszerrel $\mathrm{m} / \mathrm{z}$ 303-as aglikonnal rendelkező komponenst nem találtam.

A szurokfü esetében az m/z 271-es iontömegü aglikonnal rendelkező komponensek közül az MRM módszerrel két nagyobb csúcsot (az 71. ábrán 1. és 2. csúcsként jelölt) komponenst és több kisebb (nem számozott) csúcsot találtam. Az MRM kromatogramok és az 1-2. csúcs és fragmensarányai a 71. ábrán láthatóak. Ahogy az ábra is mutatja, az 1-2. komponensek esetében a vizsgált ionok közül az m/z 153 keletkezett a legnagyobb arányban (72\% illetve 73\%). Ezt követte az $\mathrm{m} / \mathrm{z} 121$ (20\% illetve 21\%), majd az $\mathrm{m} / \mathrm{z}$ 141, mely 8\% illetve 5\%-ban keletkezett, míg $\mathrm{m} / \mathrm{z} 215$ nem keletkezett. Ezek az arányok szintén apigenin aglikonnal rendelkező komponensekre utalnak. 


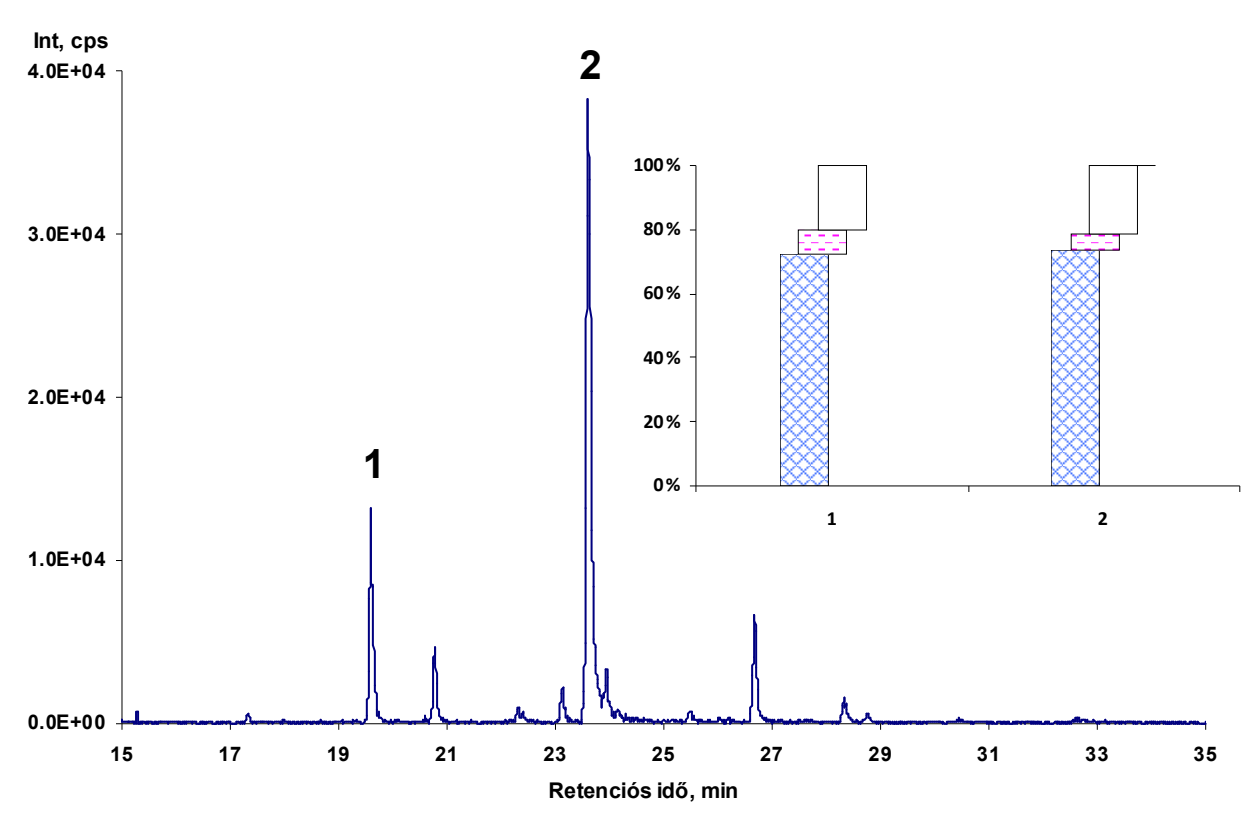

71. ábra: A szurokfü minta m/z 271 iontömegü aglikonnal rendelkezö komponenseinek MRM kromatogramja illetve fragmensarányai

(Jelmagyarázat: $=---3 \mathrm{~m} / \mathrm{z} 141, \square \times \mathrm{m} / \mathrm{z} 153, \square \mathrm{m} / \mathrm{z} 215, \square \mathrm{m} / \mathrm{z} 121$ )

A prekurzorion módszer során azt kaptam, hogy az 1. komponens m/z 623 iontömegü, mely több származékra is utalhat. Egyrészt jellemezheti az apigenin két hexozilsavval képzett származékát, másrész lehet egy dezoxihexózzal és szinapinsavval képzett származék, illetve egy hexozilsavval és ferulasavval képzett származék. A 2. komponens $m / z 447$ iontömegü volt, mely az apigenin hexozilsavval képzett származékára utal.

Az $m / z$ 287-es iontömegü aglikonnal rendelkező molekulák vizsgálatakor is két nagyobb csúcsot adó komponenst (1. és 2. jelölésü csúcs) találtam, melyek kromatogramja és fragmensarányai a 72. ábrán láthatóak. Itt az MRM módszert kiértékelve azt tapasztaltam, hogy mind az 1. és a 2. komponens esetében is hasonlóan alakultak a fragmensarányok. A legnagyobb arányban az $\mathrm{m} / \mathrm{z}$ 153-as fragmens keletkezett 63\% illetve 61\%-ban, az $\mathrm{m} / \mathrm{z} 135$ fragmens 23\% illetve 25\%-ban jött létre, $\mathrm{m} / \mathrm{z}$ 137-es fragmens $12 \%$ illetve $11 \%$-ban volt jelen, míg az $\mathrm{m} / \mathrm{z} 213$ mindkét komponensnél 3\%-ban keletkezett. Ezek az arányok ismét luteolin jelenlétére utalnak. 


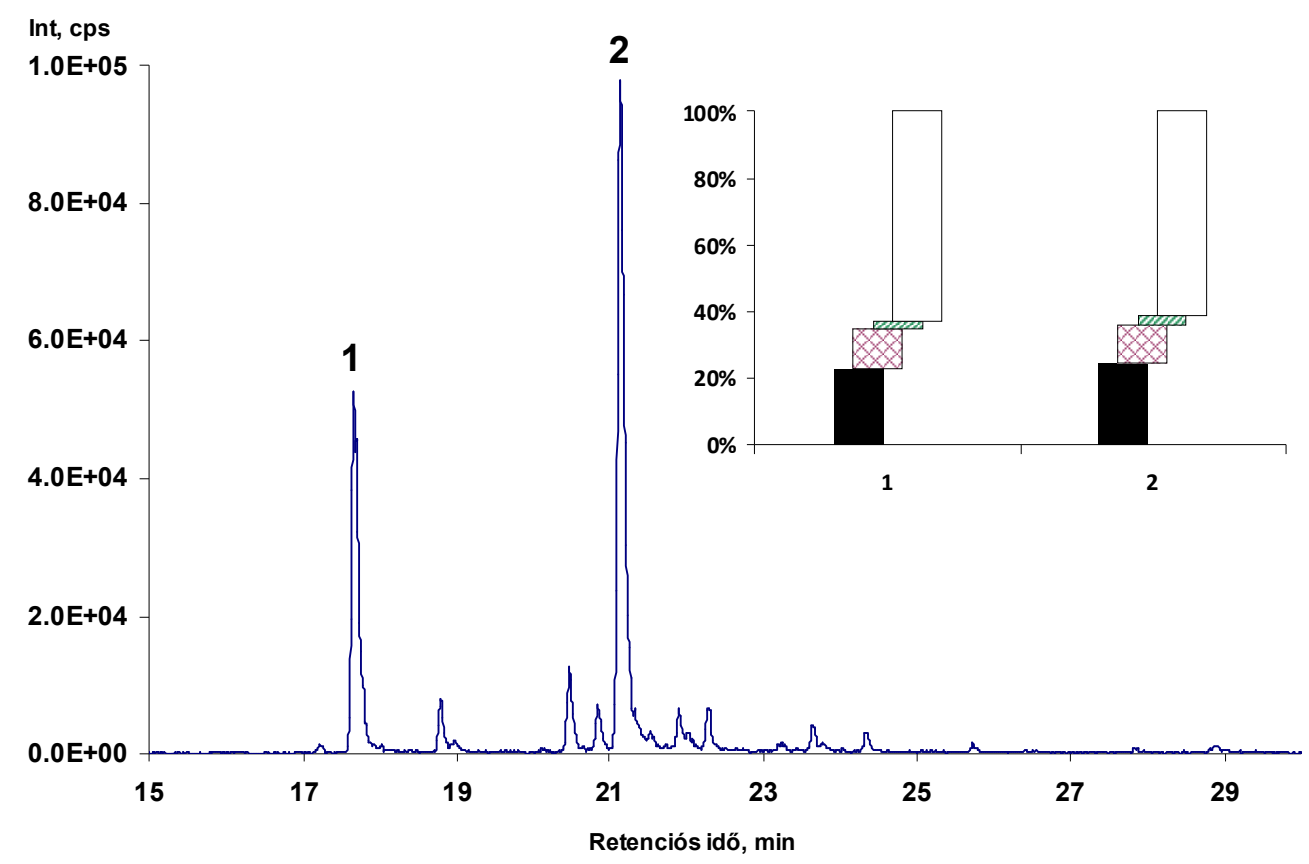

72. ábra: A szurokfü minta m/z 287 iontömegü aglikonnal rendelkezö komponenseinek MRM kromatogramja illetve fragmensarányai

(Jelmagyarázat: $\mathbb{\mathbb { L }}$ m/z 213, $\times 1 / z$ 137,

$m / z 135$,

$m / z 153)$

A prekurzorion módszer során kiderült, hogy az 1. komponens $m / z 639$ iontömegü, mely ismét több származék is lehet. Jelentheti a luteolin két hexozilsavval képzett származékát, de lehet egy dezoxihexózzal és szinapinsavval képzett származék, vagy akár egy hexozilsavval és egy ferulasavval képzett származék is. A 2. komponens $m / z 449$ iontömegü, mely a luteolin egy hexozilsavval képzett származékát valószínüsíti.

A harmadik, m/z 303-as iontömegü aglikonnal rendelkező komponensek csoportjából a módszer nem detektált komponenseket.

Ebben a kísérletben célom egy módszer kidolgozása volt, mely képes az azonos tömegszámú aglikonnal rendelkező flavonoid komponensek megkülönböztetésére és meghatározására. A módszer kidolgozásához cianidin-kaempferol-luteolin, pelargonidingenisztein-apigenin és delfinidin-heszperetin-kvercetin standardokat és ezek glikozidjait használtam. A vizsgálatok során sikerült megbizonyosodni arról, hogy az ionforrás fragmentáció során lehasadó aglikonok, illetve az eleve aglikonként jelen lévő molekulák fragmentációs mintázata azonos képet mutat, így a konjugáció nem befolyásolja a módszer megfelelőségét. A kísérletek eredményeképpen sikerült meghatározni minden azonos iontömegü aglikonnal rendelkező molekulacsoportban $(\mathrm{m} / \mathrm{z} 271, \mathrm{~m} / \mathrm{z} 287, \mathrm{~m} / \mathrm{z} 303)$ olyan négy fragmenst, melyek egymáshoz viszonyított gyakorisági aránya ezek közül csak egy fajta komponensre jellemző, 
ezáltal szelektíven meghatározható. A kidolgozott módszert négy növényfajon próbáltam ki. A házi fekete cseresznyéből két cianidin, két pelargonoidin, négy heszperetin és egy kaempferol származékot tudtam meghatározni. A kereskedelmi forgalomban kapható meggy esetében két pelargonidin, három genisztein, négy cianidin, egy kaempferol és hat kvercetin származékot sikerült azonosítani. Az 5.1. fejezetben bemutatott gyógynövényeket ezen módszerrel vizsgálva, a kakukkfüben egy apigenin és két luteolin származékot, míg a szurokfüben két apigenin és két luteolin származékot találtam. Ezek megegyeztek az 5.1. fejezetben talált komponensekkel. Összefoglalásként elmondható, hogy sikerült egy olyan módszert kidolgozni, mely képes meghatározni és megkülönböztetni az azonos összegképletü aglikonnal rendelkező (izomer) molekulákat egymástól úgy konjugátum, mint szabad formában. 


\section{6. ÚJ TUDOMÁNYOS EREDMÉNYEK}

1) Megállapítottam, hogy a kakukk- illetve szurokfüvekből nyert vizes extraktumokban lévő fenolos savak döntő többsége konjugátumok formájában vannak jelen.

Ezt a kakukkfüre jellemző sziringinsav, a szurokfüre jellemző szinapinsav valamint mindkét növényben egyaránt fontos fenolos savként jelen lévő p-kumársav és ferulasav esetén, mindkét növény több kemotípusán végzett vizsgálat alapján igazoltam.

2) Eredményeimmel igazoltam, hogy a kakukkfüben és szurokfüben lévő fenolos savakhoz társított biológiai hatások nem ítélhetők meg csupán a szabad (dekonjugált) formák biológiai hatásának vizsgálata alapján.

3) Nagy tömegfelbontású és pontos tömegmérésre alkalmas tömegspektrometriás vizsgálatokkal igazoltam, hogy az olívabogyó, az olívalevél és olívaolaj egyik legfontosabb polifenoljából, az oleuropeinből az érés és a feldolgozási technológia során keletkező, ezidáig az oleuropein aglikon izomereinek vélt alkotók egy része valójában nem izomer, hanem az oleuropein aglikon származékai.

A származékok pontos szerkezete nem ismert, vizsgálataim alapján ugyanakkor ezekről annyi megállapítható, hogy az oleuropein aglikonhoz (összegképlete: $\mathrm{C}_{19} \mathrm{H}_{20} \mathrm{O}_{8}$ ) képest $\mathrm{CH}_{4} \mathrm{O}$ molekularészlettel nagyobb $\mathrm{C}_{20} \mathrm{H}_{25} \mathrm{O}_{9}$ összegképletü alkotók jelenlétét is több esetben igazoltam.

4) Kidolgoztam egy olyan tömegspektrometriás módszert, mely alkalmas izomer aglikonnal rendelkező flavonoid glikokonjugátumok szelektív azonosítására.

Apigenin-genisztein-pelargonoidin, cianidin-kaempferol-luteolin és delfinidin-heszperetinkvercetin standardokkal, illetve ezek gliko-származékaival végzett kísérletekkel igazoltam, hogy e komponensek aglikon magját képező izomer/izobár alkotóknak meghatározhatók olyan diagnosztikus fragmens ionjai, melyek együttes vizsgálatával egyértelmüen megkülönböztethetők az azonos összegképletủ aglikonnal rendelkező flavonoid glikokonjugátumok.

Bizonyítottam továbbá, hogy az izomer/izobár aglikonok kiválasztott diagnosztikus ionjainak relatív gyakoriságai jól reprodukálhatóak és informatívak akkor is, ha az MS/MS kísérletben 
prekurzor ionként tekintett aglikon iont, a glikokonjugátumukból ionforrás fragmentációval állítottuk elő.

\section{5) Igazoltam a módszer alkalmazhatóságát valódi mintákból.}

Ennek keretében a házi fekete cseresznye mintából egy cianidin-hexozid, egy cianidin-hexoziddezoxihexóz, egy kaempferol-3-O-rutinozid, egy pelargonidin-3-O-glükozid, egy pelargonidinhexozid-dezoxihexóz komponenst találtam. Továbbá négy kvercetin molekulát, mint a kvercetindihexóz-dezoxihexózt, a kvercetin-hexozid-dezoxihexózt, egy kvercetin-hexozidot és egy pontosan beazonosított kvercetin-3-O-glükozidot találtam.

A meggy mintából két pelargonidin (pelargonidin-dihexóz-dezoxihexóz, pelargonidin-hexoziddezoxihexóz) és három genisztein (genisztein-7-glükozid, illetve további két genisztein-hexozid) komponenst határoztam meg. Továbbá három cianidin származék is azonosításra került. Ezek közül az egyik egy pentóz-hexóz-dezoxihexóz konjugátummal rendelkező cianidin származék, melyről az eredmények alapján valószínűsíthető, hogy cianidin-3-O-xilosil-rutinozid, melyet eddig csak bogyós gyümölcsökben azonosítottak. Ezen kívül azonosítottam egy kaempferol-3-O-rutinozid két kvercetin-dihexóz-dezoxihexóz, két kvercetin-hexóz-dezoxihexóz, két kvercetin-hexozid származékot, melyek közül az egyik egy kvercetin-3-O-glükozid.

Továbbá a gyógynövények flavonoid mintázatának feltérképezéséhez használt mintákat is felhasználtam a módszer bemutatásához, melynek eredményeképpen sikerült a fó komponenseket azonosítani. 


\section{7. ÖSSZEFOGLALÁS}

A polifenolok egészségre gyakorolt jótékony hatását már számos kísérlet igazolta. Ugyanakkor az a kérdés, hogy pontosan mi is okozza e vegyületek pozitív tulajdonságát, még számos esetben nem tisztázott. Korábban e tekintetben szinte kizárólag a polifenolok antioxidáns hatásának tulajdonítottak jelentőséget. Mára azonban egyre inkább az a szemlélet kezd uralkodóvá válni, mely megkérdőjelezi, hogy a polifenolok kémiai tesztekben mutatott antioxidáns sajátságai párhuzamba állíthatók az in vivo körülmények között megmutatkozó biológiai hatások mögött meghúzódó folyamatokkal. Napjainkban egyre több kutatás célja tehát, hogy megismerje a polifenolok valódi hatásmechanizmusait.

A polifenolok az emberi szervezetbe a táplálkozás során elfogyasztott növényekkel jutnak be. A polifenolok valódi hatásmechanizmusainak megismerését nehezíti, hogy egy-egy jól ismert és in vitro kísérletekben sokat vizsgált flavonoid, vagy fenolos sav a növényekben nem önmagában, szabadon, hanem cukrokkal, szerves savakkal alkotott konjugátumok formájában van jelen. A nagyszámú, lehetséges konjugátum kombináció miatt, sok esetben nem is ismerjük pontosan milyen polifenol-konjugátumok fordulnak elő a táplálékként szolgáló növényekben. Ezért a hatásmechanizmus felderítésére irányuló kutatások előfeltétele, hogy ismerjük a szervezetbe bekerülő polifenolok pontos kémiai felépítését. Ez azért fontos, mert az egyes polifenolok szervezetben kifejtett hatása nagyban függ attól, hogy az adott polifenol pontosan milyen formában van jelen. A polifenol konjugátumok intakt formáinak vizsgálata, feltérképezése összetett feladat és ezek vizsgálatára a folyadékkromatográfiával kapcsolt tömegspektrometria szolgáltatja leghatékonyabb mérési megközelítést.

Doktori munkámban olyan speciális tömegspektrometriás polifenol vizsgálati módszereket alkalmaztam és fejlesztettem, melyek alkalmasak egyes növényekben található polifenolkonjugátumok pontosabb megismerése és feltérképezésére.

Elsőként kakukk- illetve szurokfüvek polifenoljainak vizsgálatával foglalkoztam. Ezen belül a hazai termesztésü kaukkfüvek (Thymus vulgaris L.) „timolos” illetve „,nem timolos” populációját továbbá a szintén hazai termesztésű szurokfüvek görög (Origanum vulgare L. subsp. hirtum), illetve közönséges (Origanum vulgare L. subsp. vulgare) populációját hasonlítottam össze fenolos sav illetve flavonoid komponenseiket figyelembe véve. A kísérletek során olyan módszereket alkalmaztam, melyekkel vizsgálni tudtam a származék formában illetve szabadon előforduló legjellemzőbb fenolsavak arányát. A fenolos savak méréséhez tömegspektrometriás célkomponens módszert alkalmaztam, melyet kétfajta minta-előkészítés előzött meg. Egyrészt egyszerü vizes 
extrakcióval próbáltam minél kíméletesebben kinyerni a gyógynövényekben található komponenseket. Másrészt a vizes extraktum lúgos hidrolízisével az összetett (konjugált) formában lévő komponensek szabaddá tétele volt a célom annak érdekében, hogy így azok láthatóvá váljanak a tömegspektrometriás célkomponens módszer számára. Az eredmények azt mutatták, hogy erre a lépésre szükség is volt, hiszen, az egyszerü vizes extrakcióval kinyert fenolos savak mennyisége 20-100-szor kevesebbnek bizonyult, mint amilyen a hidrolizáció után mért eredmény volt. A vizsgált gyógynövényekben az irodalomnak megfelelően a rozmaringsav volt jelen a legnagyobb koncentrációban. Azonban a ferulasav és a p-kumársav illetve a kakukkfü esetében a sziringinsav is jelentős mennyiségben fordult elő. A klorogénsav koncentrációja 3-40-szerese, a kávésav koncentrációja 10-szerese volt a szurokfüvekben, mint a közönséges kakukkfüvekben populációtól függően. Továbbá klorogénsavból ötször, ferulasavból kétszer, szinapinsavból háromszor nagyobb koncentrációt mértem a görög oregánó mintában, mint a közönséges szurokfüben. A kakukkfüveknél a „timolos” mintákban a sziringinsav és rozmaringsav kétszer nagyobb mennyiségben volt jelen, mint a „nem timolos” típusban.

A fenolos savak vizsgálata során alkalmazott módszer a konjugált/szabad formák arányára vonatkozóan, a minta-előkészítés során alkalmazott lúgos hidrolízist felhasználva tudott választ adni. Arról ez a megközelítés azonban nem nyújtott információt, hogy a konjugált formák esetében valójában milyen molekularészletek konjugálódtak az alapmolekulákhoz. A flavonoidok feltérképezése során ezért egy másik megközelítést alkalmaztam. A tömegspektrometriás módszerekben rejlő lehetőségeket kihasználva kívántam a konjugált ún. glikán részek minőségéről is információhoz jutni. Az eredmények azt mutatták, hogy mindkét vizsgált növénytípusban az apigenin és a luteolin aglikonnal rendelkező komponensek vannak jelen a legnagyobb mennyiségben. A kakukkfüben luteolin származékból három, apigeninből egy, továbbá egy naringenin konjugátum, míg a szurokfü esetében luteolin aglikonnal rendelkező komponensből négy, apigeninből két származék azonosítását végeztem el.

Munkám második részében az olívaolajokban, az olívabogyóban és az olívalevélben található, jellemző polifenolnak, az oleuropeinnek illetve e komponens szabad formájának, az oleuropein aglikonnak vizsgálatával foglalkoztam. A kutatás apropóját az irodalomban közölt azon megfigyelések adták, miszerint az oleuropein aglikon és ligsztrozid aglikonok nem célzott vizsgálata során e vegyületek számos izomer formáját mutatták ki. Ezen izomerek létezésére, illetve létjogosultságára meggyőző biológiai magyarázatokkal nem rendelkezünk. Kérdésként merült fel tehát, hogy valóban izomer formák-e ezek a kimutatott és izomereknek tekintett alkotók. Nem lehet, hogy ezek valójában nem izomerek, hanem valamilyen oleuropein származékok, melyek a vizsgálati módszerek hibás alkalmazása miatt vezettek hibás konklúziókra? Vizsgálataim 
során nem célzott módon történő tömegspektrometriás vizsgálatokat hajtottam végre annak érdekében, hogy az iménti hipotézist vizsgálhassam. Eredményeim azt mutatták, hogy az általam vizsgált mintatípusokban korábban izomereknek feltételezett alkotók egy része valójában nem izomer. Ezek egy részéről igazolni tudtam, hogy ezek oleuropein származékok, melyekről azonban nem tudtam megállapítani, hogy azok a minta endogén alkotói, vagy a minta-előkészítés hatására keletkezett „mütermékek”.

Doktori munkám harmadik részében egy olyan speciális tömegspektrometriás módszer kifejlesztését mutattam be, mely az azonos iontömegü aglikonnal rendelkező flavonoid glikokonjugátumok megkülönböztetésére és meghatározására alkalmas. Ilyen módszerre azért lehet szükség, mert a konstitúciós izomerek szelektív azonosítása még a nagy tömegfelbontású MS készülékek esetében sem lehetséges. Munkám során sikerült erre a problémára megoldást találnom olyan tandem tömegspektrometriás vizsgálati módszer alkalmazásával, melyben a flavonoid glikokonjugátumokból ionforrás fragmentációval előállított (izomer) aglikon ionokat további szelektivitást eredményező fragmentációnak vetettem alá. Ezt követően olyan jellemző fragmensionokat választottam további vizsgálatra, melyek keletkezési gyakorisága specifikus a komponensekre nézve, függetlenül attól, hogy aglikonként vagy származékként fordulnak elő a mintában. A módszer megfelelőségét standard polifenolok vizsgálatán túl, valódi minták vizsgálatával is igazoltam. Ennek keretében cseresznye, meggy, illetve az első témakörben szereplő két gyógynövényfajta, azaz a kakukkfü és a szurokfü minták vizsgálatát végeztem el, melynek során példákkal igazoltam a módszer megfelelőségét. 


\section{SUMMARY}

The health benefits of polyphenolic compounds have been demonstrated in many studies. However, several researches attempts are carried out to answer what exactly causes the positive properties of these compounds. Until now, almost exclusively the antioxidant capacity was attributed to this effect. Nowadays, an approach is becoming more dominant, which questions the fact that antioxidant properties of the polyphenols observed in chemical tests could provide thorough explanation of the in vivo biological effects. Therefore, more and more researchers aim to study these mechanisms at the molecular level.

Polyphenols get into the human body via plant foods. It is difficult to understand the real mechanisms of polyphenols since much of the wll-known polyphenols in plants are present not in their in free forms but as conjugated compounds, mostly attached to sugars and organic acids. Due to the large number of possible combinations of polyphenol conjugates, in many cases the actual derivates occuring in plants are not exactly known. Therefore, to get detailed information on the chemical structure of the polyphenols entering the body can be considered as a kind of precondition of any research targeting to reveal their real mechanism of action. This is important because it is known that the effect may depend largely on the exact form of the actual polyphenol. The analysis of the intact polyphenol conjugates is a complex task. The most effective approach to study these components is the liquid chromatography coupled to mass spectrometry.

In my PhD study, mass spectrometric methods were used and developed for the analysis of polyphenols, which were designed to provide support for the more accurate discovery and thus the better understanding the polyphenol conjugates in plants.

First, the focus was set on polyphenol analysis of Thyme and Oregano plants grown in Hungary. In this study, two population (i.e., thymol-type and non-thymol-type) of Thymus vulgaris L.) and two populations of oregano ("Common" (Origanum vulgare L. subsp. vulgare) and Greek (Origanum vulgare L. subsp. hirtum)) were examined to compare their phenolic acid and flavonoid patterns. Analyses were carried out followed by two different types of sample preparation in order to investigate the ratio of the conjugated and non-conjugated phenolic acids present in the aqueous extract. The first was a simple dilution of the aqueous extract, but the second included an alkaline hydrolysis step. The aqueous, non-hydrolyzed extract represents the amounts of unconjugated phenolic acids, while concentrations measured in the hydrolyzed extracts indicate the total amount of conjugated and unconjugated phenolic acids present in the aqueous extract. Experiments were carried out using high performance liquid chromatography-electrospray ionization-tandem mass spectrometry (HPLC-ESI-MS/MS). 
Results showed that the two-step sample preparation was necessary. The concentration of the phenolic acids in the simple aqueous extract was 20-100 times less than after alkaline hydrolyzis. In the analyzed herbs, rosmarminic acid was the main phenolic component. However, ferulic acid, pcoumaric acid, and in the case of Thyme, siringinic acid were present also in remarkable concentrations. Chlorogenic acid was 3 to 40 times higher and and caffeic acid was $\sim 10$ times higher in the Oregano than in the Thyme. Furthermore in the Greek oregano population the concentration of chlorogenic acid, ferulic acid, and sinapic acid was 5x, 2x and 3x higher than in the Common oregano population respectively. In the case of the thymol-type population, the amount of siriginic acid and rosmarinic acid was two times higher compared to the non-thymoltype population.

As it is shown, it was neccessary to use an alkaline hydolysis to determine the ratio of the free (non-conjugated) and conjugated forms of the phenolic acids. Nevertheless, this method is not suitable to identify the type of moieties conjugated to the aglycone. Terefore, I used another experimental approach in the case of flavonoid analysis. I also aimed to determine the glycan moieties by mass spectrometry. The results showed that in both of the herbs, apigenin and luteolin glycoconjugates have the highest concentrations. In Thyme, three luteolin, one apigenin and one naringenin derivates were determined, while in Oregano four luteolin and two apigenin derivates were observed.

The next part of my work was dealing with olive oils, olive fruit and olive leaves, in order to examine forms of the oleuropein aglycone. The idea came from the literature where numerous oleuropein and ligstroside isomers were determined by screening methods. However, we do not yet sole chemical or biological explanation for the presence of these isomers. Thus it is still doubted, whether these compounds are truly isomer forms or rather they are some type of oleuropein aglycone derivates. In this study, non-target mass spectrometric methods were used in order to make an attempt for answering this question. The results showed that in the same sample types studied in the literature, not all the compound assigend as isomers, are isomers. It was proved that a part of these compounds are oleuropein derivates, however it is not known, wheter these are endogenous compounds of the sample or artefacts formed as a result of sample preparation.

In the third part of my study, a mass spectrometric method was developed and presented, specialized for the distinguishing among the flavonoid glycoconjugates having isomeric aglycon nuclei. Such methods are needed, since the selective identification of the structural flavonoid isomers is not possible even by high-resolution tandem mass spectrometry. In my work, this analytical problem was succesfully solved by developing a mass spectrometric method where the ion-source generated (isomeric) aglycone fragments were further fragmented in the collision cell of 
the mass spectrometer. Diagnostic fragment ions were chosen, whose abundance ratio were turned out to be specific for the analyzed components, regardless of the precursor from whch the aglycone fragment was cleaved. The suitability of this method, were demonstrated with not only standards, but also with real samples (sour and sweet cherry, thyme and oregano). 


\section{IRODALOM}

ABAD-GARCÍA, B., BERRUETA, L. A., GARMÓN-LOBATO, S., GALLO, B. \& VICENTE, F. (2009): A general analytical strategy for the characterization of phenolic compounds in fruit juices by high-performance liquid chromatography with diode array detection coupled to electrospray ionization and triple quadrupole mass spectrometry. Journal of Chromatography A, 1216 (28) 5398-5415. p.

ABRANKO, L., GARCIA-REYES, J. F. \& MOLINA-DIAZ, A. (2011): In-source fragmentation and accurate mass analysis of multiclass flavonoid conjugates by electrospray ionization time-of-flight mass spectrometry. Journal of Mass Spectrometry, 46 (5) 478-88. p. 10.1002/jms.1914.

ABRANKÓ, L., GARCÍA-REYES, J. F. \& MOLINA-DÍAZ, A. (2012): Systematic bottom-up approach for flavonoid derivative screening in plant material using liquid chromatography high-resolution mass spectrometry. Analytical and bioanalytical chemistry, 403 (4) 9951006. p.

ABRANKÓ, L., NAGY, Á., SZILVÁSSY, B., STEFANOVITS-BÁNYAI, É. \& HEGEDÜS, A. (2014): Genistein isoflavone glycoconjugates in sour cherry (Prunus cerasus L.) cultivars. Food Chemistry, megjelenés alatt (-) -. p.

ALONSO-SAlCES, R. M., KORTA, E., BARRANCO, A., BERRUETA, L. A., GALlO, B. \& VICENTE, F. (2001): Determination of polyphenolic profiles of Basque cider apple varieties using accelerated solvent extraction. Journal of Agricultural and Food Chemistry, 49 (8) 3761-7.p.

ALTıOK, E., BAYÇıN, D., BAYRAKTAR, O. \& ÜLKÜ, S. (2008): Isolation of polyphenols from the extracts of olive leaves (Olea europaea L.) by adsorption on silk fibroin. Separation and Purification Technology, 62 (2) 342-348. p. http://dx.doi.org/10.1016/j.seppur.2008.01.022.

ANDERSEN, Ø. M. \& MARKHAM, K. R. (2006): Flavonoids Chemistry, Biochemistry and Applications, CRC Press Taylor \& Francis Group.

ANDRÉS-LACUEVA, C., MEDINA-REMON, A., LLORACH, R., URPI-SARDA, M., KHAN, N., CHIVA-BLANCH, G., ZAMORA-ROS, R., ROTCHES-RIBALTA, M. \& LAMUELARAVENTÓS, R. M. (2009): Phenolic Compounds: Chemistry and Occurrence in Fruits and Vegetables. Fruit and Vegetable Phytochemicals. Wiley-Blackwell. 10.1002/9780813809397.ch2 
ARABBI, P. R., GENOVESE, M. I. \& LAJOLO, F. M. (2004): Flavonoids in vegetable foods commonly consumed in Brazil and estimated ingestion by the Brazilian population. Journal of Agricultural and Food Chemistry, 52 (5) 1124-1131. p.

ARTS, I. C., VAN DE PUTTE, B. \& HOLLMAN, P. C. (2000a): Catechin contents of foods commonly consumed in The Netherlands. 1. Fruits, vegetables, staple foods, and processed foods. J Agric Food Chem, 48 (5) 1746-51.p.

ARTS, I. C. W., VAN DE PUTTE, B. \& HOLLMAN, P. C. H. (2000b): Catechin Contents of Foods Commonly Consumed in The Netherlands. 2. Tea, Wine, Fruit Juices, and Chocolate Milk. Journal of Agricultural and Food Chemistry, 48 (5) 1752-1757. p. $10.1021 / \mathrm{jf000026+.}$

ASHIHARA, A. C. M. N. C. H. (2006): Plant Secondary Metabolites, Occurrence, Structure and Role in the Human Diet, Blackwell Publishing Ltd.

BARNES, J. S., NGUYEN, H. P., SHEN, S. \& SCHUG, K. A. (2009): General method for extraction of blueberry anthocyanins and identification using high performance liquid chromatography-electrospray ionization-ion trap-time of flight-mass spectrometry. Journal of Chromatography A, 1216 (23) 4728-4735. p.

BEHLOUL, N. \& WU, G. (2013): Genistein: a promising therapeutic agent for obesity and diabetes treatment. European Journal of Pharmacology, 698 (1-3) 31-38. p.

BENSMIRA, M., JIANG, B., NSABIMANA, C. \& JIAN, T. (2007): Effect of lavender and thyme incorporation in sunflower seed oil on its resistance to frying temperatures. Food Research International, 40 (3) 341-346.p.

BHAGWAT, S., HAYTOWITZ, D. B. \& HOLDEN, J. M. (2008): USDA database for the isoflavone content of selected foods. Release 2.0.

BIANCO, A. \& UCCELLA, N. (2000): Biophenolic components of olives. Food Research International, 33 (6) 475-485. p.

BLANDO, F., GERARDI, C. \& NICOLETTI, I. (2004): Sour Cherry (Prunus cerasus L) Anthocyanins as Ingredients for Functional Foods. Journal of Biomedicine and Biotechnology, 2004 (5) 253-258. p. 10.1155/s1110724304404136.

BOLlinG, B. W., DOLNIKOWSKI, G., BLUMBERG, J. B. \& OLIVER CHEN, C. Y. (2009): Quantification of Almond Skin Polyphenols by Liquid Chromatography-Mass Spectrometry. Journal of Food Science, 74 (4) C326-C332. p. 10.1111/j.17503841.2009.01133.x. 
BONERZ, D., WÜRTH, K., DIETRICH, H. \& WILL, F. (2007): Analytical characterization and the impact of ageing on anthocyanin composition and degradation in juices from five sour cherry cultivars. European Food Research and Technology, 224 (3) 355-364. p.

BONOLI, M., BENDINI, A., CERRETANI, L., LERCKER, G. \& TOSCHI, T. G. (2004): Qualitative and semiquantitative analysis of phenolic compounds in extra virgin olive oils as a function of the ripening degree of olive fruits by different analytical techniques. Journal of Agricultural and Food Chemistry, 52 (23) 7026-32. p. 10.1021/jf048868m.

BRENES, M., HIDALGO, F., GARCÍA, A., RIOS, J., GARCÍA, P., ZAMORA, R. \& GARRIDO, A. (2000): Pinoresinol and 1-acetoxypinoresinol, two new phenolic compounds identified in olive oil. Journal of the American Oil Chemists' Society, 77 (7) 715-720. p. 10.1007/s11746-000-0115-4.

BRIANTE, R., PATUMI, M., TERENZIANI, S., BISMUTO, E., FEBBRAIO, F. \& NUCCI, R. (2002): Olea europaea L. leaf extract and derivatives: antioxidant properties. Journal of Agricultural and Food Chemistry, 50 (17) 4934-4940. p.

BROUILLARD, R. (1982): Chemical structure of anthocyanins. In: MARKAKIS, PERICLES (ed.) Anthocyanins as Food Colors. Elsevier, Technology \& Engineering.

BROUILLARD, R., CHASSAING, S. \& FOUGEROUSSE, A. (2003): Why are grape/fresh wine anthocyanins so simple and why is it that red wine color lasts so long? Phytochemistry, 64 (7) 1179-1186. p. http://dx.doi.org/10.1016/S0031-9422(03)00518-1.

BROUILLARD, R. \& CHEMINAT, A. (1988): Flavonoids and plant color. Progress in Clinical and Biological Research, 280 93-106. p.

BRUNETON, J. (1995): Pharmacognosy. Phytochemistry, Medicinal Plants, 2 330-887. p.

CABRITA, L. (1999): Analysis and stability of anthocyanins, University of Bergen, Department of Chemistry.

CAI, Y., LUO, Q., SUN, M. \& CORKE, H. (2004): Antioxidant activity and phenolic compounds of 112 traditional Chinese medicinal plants associated with anticancer. Life Sciences, 74 (17) 2157-84. p. 10.1016/j.1fs.2003.09.047.

CAPASSO, R., EVIDENTE, A., VISCA, C., GIANFREDA, L., MAREMONTI, M. \& GRECO, G. (1997): Production of glucose and bioactive aglycone by chemical and enzymatic hydrolysis of purified oleuropein from Olea Europea. Applied Biochemistry and Biotechnology, 61 (3) 365-377. p.

CARDOSO, S. M., FAlCÃO, S. I., PERES, A. M. \& DOMINGUES, M. R. (2011): Oleuropein/ligstroside isomers and their derivatives in Portuguese olive mill wastewaters. Food Chemistry, 129 (2) 291-296. p. 
CARrasco-PANCORBO, A., NEUSUSS, C., PELZING, M., SEGURA-CARRETERO, A. \& FERNANDEZ-GUTIERREZ, A. (2007): CE- and HPLC-TOF-MS for the characterization of phenolic compounds in olive oil. Electrophoresis, 28 (5) 806-21. p. 10.1002/elps.200600382.

CHAOVANALIKIT, A. \& WROLSTAD, R. (2004): Anthocyanin and polyphenolic composition of fresh and processed cherries. Journal of Food Science, 69 (1) FCT73-FCT83. p.

CHEN, A. Y. \& CHEN, Y. C. (2013): A review of the dietary flavonoid, kaempferol on human health and cancer chemoprevention. Food Chemistry, 138 (4) 2099-2107. p. http://dx.doi.org/10.1016/j.foodchem.2012.11.139.

CLIFFORD, M. N. (2000): Anthocyanins - nature, occurrence and dietary burden. Journal of the Science of Food and Agriculture, 80 (7) 1063-1072. p. 10.1002/(SICI)10970010(20000515)

COOPER-DRIVER, G. A. (2001): Contributions of Jeffrey Harborne and co-workers to the study of anthocyanins. Phytochemistry, 56 (3) 229-236. p. http://dx.doi.org/10.1016/S00319422(00)00455-6.

COVAS, M.-I. (2007): Olive oil and the cardiovascular system. Pharmacological Research, 55 (3) 175-186. p.

COWARD, L., SMITH, M., KIRK, M. \& BARNES, S. (1998): Chemical modification of isoflavones in soyfoods during cooking and processing. American Journal of Clinical Nutrition, 68 (6 Suppl) 1486S-1491S. p.

CREGO, A., IBÁÑEZ, E., GARCÍA, E., DE PABLOS, R., SEÑORÁNS, F., REGLERO, G. \& CIFUENTES, A. (2004): Capillary electrophoresis separation of rosemary antioxidants from subcritical water extracts. European Food Research and Technology, 219 (5) 549556. p. 10.1007/s00217-004-0980-8.

CROZIER, A., DEL RIO, D. \& CLIFFORD, M. N. (2010): Bioavailability of dietary flavonoids and phenolic compounds. Molecular Aspects of Medicine, 31 (6) 446-467. p. iu:1017/S007114510002424

CROZIER, A., JAGANATH, I. B. \& CLIFFORD, M. N. (2009): Dietary phenolics: chemistry, bioavailability and effects on health. Natural Product Reports, 26 (8) 1001-1043. p. 10.1039/B802662A.

CUYCKENS, F. \& CLAEYS, M. (2004): Mass spectrometry in the structural analysis of flavonoids. Journal of Mass Spectrometry, 39 (1) 1-15. p. 
D’ANTUONO, L. F., GALLETTI, G. C. \& BOCCHINI, P. (2000): Variability of essential oil content and composition of Origanum vulgare L. populations from a North Mediterranean area (Liguria region, Northern Italy). Annals of Botany, 86 (3) 471-478. p.

DA COSTA, C. T., NELSON, B. C., MARGOLIS, S. A. \& DEREK, H. (1998): Separation of blackcurrant anthocyanins by capillary zone electrophoresis. Journal of Chromatography A, 799 (1-2) 321-327. p. http://dx.doi.org/10.1016/S0021-9673(97)01043-1.

DAUCheT, L., AMOUYEL, P., HERCBERG, S. \& DAllongEVILlE, J. (2006): Fruit and vegetable consumption and risk of coronary heart disease: a meta-analysis of cohort studies. The Journal of nutrition, 136 (10) 2588-2593. p.

DAUCHET, L. \& DALLONGEVILLE, J. (2008): Fruit and vegetables and cardiovascular disease: epidemiological evidence from the non-Western world. British Journal of Nutrition, 99 (02) 219-220.p.

DAY, A. J., CANADA, F. J., DIAZ, J. C., KROON, P. A., MCLAUCHLAN, R., FAULDS, C. B., PLUMB, G. W., MORGAN, M. R. A. \& WILLIAMSON, G. (2000): Dietary flavonoid and isoflavone glycosides are hydrolysed by the lactase site of lactase phlorizin hydrolase. Febs Letters, 468 (2-3) 166-170. p. 10.1016/s0014-5793(00)01211-4.

DE ANCOS, B., GONZALEZ, E. \& CANO, M. P. (1999): Differentiation of raspberry varieties according to anthocyanin composition. Zeitschrift für Lebensmitteluntersuchung und Forschung A, 208 (1) 33-38. p. 10.1007/s002170050371.

DE LA TORRE-CARBOT, K., JAUREGUI, O., GIMENO, E., CASTELLOTE, A. I., LAMUELARAVENTOS, R. M. \& LOPEZ-SABATER, M. C. (2005): Characterization and quantification of phenolic compounds in olive oils by solid-phase extraction, HPLC-DAD, and HPLC-MS/MS. Journal of Agricultural and Food Chemistry, 53 (11) 4331-40. p. $10.1021 / \mathrm{jf0501948.}$

DE RIJKE, E., DE KANTER, F., ARIESE, F., BRINKMAN, U. A. \& GOOIJER, C. (2004): Liquid chromatography coupled to nuclear magnetic resonance spectroscopy for the identification of isoflavone glucoside malonates in T. pratense L. leaves. Journal of Separation Science, 27 (13) 1061-70. p. 10.1002/jssc.200401844.

DE RIJKE, E., OUT, P., NIESSEN, W., ARIESE, F., GOOIJER, C. \& BRINKMAN, U. A. T. (2006): Analytical separation and detection methods for flavonoids. Journal of Chromatography A, 1112 (1) 31-63. p.

DEL RIO, D., BORGES, G. \& CROZIER, A. (2010): Berry flavonoids and phenolics: bioavailability and evidence of protective effects. British Journal of Nutrition, 104 S67S90.p. 10.1017/s0007114510003958. 
DEL RIO, D., RODRIGUEZ-MATEOS, A., SPENCER, J. P., TOGNOLINI, M., BORGES, G. \& CROZIER, A. (2013): Dietary (poly)phenolics in human health: structures, bioavailability, and evidence of protective effects against chronic diseases. Antioxid Redox Signal, 18 (14) 1818-92. p. 10.1089/ars.2012.4581.

DEY, P. M. \& HARBORNE, J. B. (1993): Methods in plant biochemistry, Academic Press.

DIRLEWANGER, E., CLAVERIE, J., IEZZONI, A. F. \& WÜNSCH, A. (2009): Sweet and sour cherries: linkage maps, QTL detection and marker assisted selection. Plant Genetics and Genomics: Crops and Models. Springer.Genetics and genomics of Rosaceae.

DORMAN, H. D., SURAI, P. \& DEANS, S. G. (2000): In vitro antioxidant activity of a number of plant essential oils and phytoconstituents. Journal of Essential Oil Research, 12 (2) 241248. p.

DRAGOVIC-UZELAC, V., POSPIŠIL, J., LEVAJ, B. \& DELONGA, K. (2005): The study of phenolic profiles of raw apricots and apples and their purees by HPLC for the evaluation of apricot nectars and jams authenticity. Food Chemistry, 91 (2) 373-383. p.

DUTHIE, G. G., DUTHIE, S. J. \& KYLE, J. A. (2000): Plant polyphenols in cancer and heart disease: implications as nutritional antioxidants. Nutr Res Rev, 13 (1) 79-106. p. $10.1079 / 095442200108729016$.

ESTI, M., CINQUANTA, L. \& LA NOTTE, E. (1998): Phenolic compounds in different olive varieties. Journal of Agricultural and Food Chemistry, 46 (1) 32-35. p.

FAY, L. B., KUSSMANN, M., BELTON, P. S. \& DOWNEY, G. (2010): Mass spectrometry and nutrition research, Royal Society of Chemistry.

FECKA, I. \& TUREK, S. (2008): Determination of polyphenolic compounds in commercial herbal drugs and spices from Lamiaceae: thyme, wild thyme and sweet marjoram by chromatographic techniques. Food Chemistry, 108 (3) 1039-1053. p.

FENG, Y., MCDONALD, C. E. \& VICK, B. A. (1988): C-glycosylflavones from hard red spring wheat bran. Cereal chemistry., 65 (6) 452-456. p.

FITO, M., GUXENS, M., CORELla, D., SAEZ, G., ESTRUCH, R., DE LA TORRE, R., FRANCES, F., CABEZAS, C., LOPEZ-SABATER, M. D. C. \& MARRUGAT, J. (2007): Effect of a traditional Mediterranean diet on lipoprotein oxidation: a randomized controlled trial. Archives of internal medicine, 167 (11) 1195. p.

FLESCHHUT, J., KRATZER, F., RECHKEMMER, G. \& KULLING, S. E. (2006): Stability and biotransformation of various dietary anthocyanins in vitro. European Journal of Nutrition, 45 (1) 7-18. p. 10.1007/s00394-005-0557-8. 
FRAGA, C. G., GALleANO, M., Verstraeten, S. V. \& OTEIZA, P. I. (2010): Basic biochemical mechanisms behind the health benefits of polyphenols. Mol Aspects Med, 31 (6) 435-45. p. 10.1016/j.mam.2010.09.006.

FRANCIS, F. J. (1989): Food colorants: anthocyanins. Critical Reviews in Food Science and Nutrition, 28 (4) 273-314. p. 10.1080/10408398909527503.

FRANKE, A. A., CUSTER, L. J., ARAKAKI, C. \& MURPHY, S. P. (2004): Vitamin C and flavonoid levels of fruits and vegetables consumed in Hawaii. Journal of Food Composition and Analysis, 17 (1) 1-35. p.

FRANKE, A. A., CUSTER, L. J., CERNA, C. M. \& NARALA, K. K. (1994): Quantitation of Phytoestrogens in Legumes by HPLC. Journal of Agricultural and Food Chemistry, 42 (9) 1905-1913. p. 10.1021/jf00045a015.

FU, S., ARRAEZ-ROMAN, D., MENENDEZ, J. A., SEGURA-CARRETERO, A. \& FERNANDEZ-GUTIERREZ, A. (2009): Characterization of isomers of oleuropein aglycon in olive oils by rapid-resolution liquid chromatography coupled to electrospray time-offlight and ion trap tandem mass spectrometry. Rapid Communications in Mass Spectrometry, 23 (1) 51-9. p. 10.1002/rcm.3855.

FU, S., ARRAEZ-ROMAN, D., SEGURA-CARRETERO, A., MENENDEZ, J. A., MENENDEZGUTIERREZ, M. P., MICOL, V. \& FERNANDEZ-GUTIERREZ, A. (2010): Qualitative screening of phenolic compounds in olive leaf extracts by hyphenated liquid chromatography and preliminary evaluation of cytotoxic activity against human breast cancer cells. Analytical and bioanalytical chemistry, 397 (2) 643-54. p. 10.1007/s00216010-3604-0.

FURTADO, M. A., DE ALMEIDA, L. C. F., FURTADO, R. A., CUNHA, W. R. \& TAVARES, D. C. (2008): Antimutagenicity of rosmarinic acid in Swiss mice evaluated by the micronucleus assay. Mutation Research/Genetic Toxicology and Environmental Mutagenesis, 657 (2) 150-154. p.

GILBERT-LÓPEZ, B., VALENCIA-REYES, Z. L., YUFRA-PICARDO, V. M., GARCÍAREYES, J. F., RAMOS-MARTOS, N. \& MOLINA-DÍAZ, A. (2014): Determination of Polyphenols in Commercial Extra Virgin Olive Oils from Different Origins (Mediterranean and South American Countries) by Liquid Chromatography-Electrospray Time-of-Flight Mass Spectrometry. Food Analytical Methods, 1-10. p.

GREVSEN, K., FRETTE, X. \& CHRISTENSEN, L. P. (2009): Content and composition of volatile terpenes, flavonoids and phenolic acids in Greek oregano (Origanum vulgare L. 
ssp. hirtum) at different development stages during cultivation in cool temperate climate. European Journal of Horticultural Science, 74 (5) 193. p.

GRIEVE, M. (1992): A Modern Herbal,, London, Tiger Books International

GUTIÉRREZ, A. \& CARRETERO, A. (2009): El Aceite de Oliva Virgen: Tesoro de Andalucía. Servicio de Publicaciones de la Fundación Unicaja, 9-14. p.

GUTIÉRREZ, F., ALBI, M. A., PALMA, R., RIOS, J. J. \& OLÍAS, J. M. (1989): Bitter Taste of Virgin Olive Oil: Correlation of Sensory Evaluation and Instrumental HPLC Analysis. Journal of Food Science, 54 (1) 68-70. p. 10.1111/j.1365-2621.1989.tb08569.x.

HALLIWELL, B. (2000): The antioxidant paradox. The Lancet, 355 (9210) 1179-1180. p.

HALLIWELL, B. (2007): Dietary polyphenols: Good, bad, or indifferent for your health? Cardiovascular Research, 73 (2) 341-347. p. 10.1016/j.cardiores.2006.10.004.

HAMAGUCHI, T., ONO, K., MURASE, A. \& YAMADA, M. (2009): Phenolic compounds prevent Alzheimer's pathology through different effects on the amyloid- $\beta$ aggregation pathway. The American journal of pathology, 175 (6) 2557-2565. p.

HARBAUM, B., HUBBERMANN, E. M., WOLFF, C., HERGES, R., ZHU, Z. \& SCHWARZ, K. (2007): Identification of Flavonoids and Hydroxycinnamic Acids in Pak Choi Varieties ( Brassica campestris L. ssp. chinensis var. communis) by HPLC-ESI-MS n and NMR and Their Quantification by HPLC-DAD. Journal of Agricultural and Food Chemistry, 55 (20) 8251-8260. p.

HARBORNE, J. B. (1993): The flavonoids advances in research since 1986, CRC Press.

HARNLY, J. M., BHAGWAT, S. \& LIN, L.-Z. (2007): Profiling methods for the determination of phenolic compounds in foods and dietary supplements. Analytical and bioanalytical chemistry, 389 (1) 47-61. p.

HARNLY, J. M., DOHERTY, R. F., BEECHER, G. R., HOLDEN, J. M., HAYTOWITZ, D. B., BHAGWAT, S. \& GEBHARDT, S. (2006): Flavonoid content of US fruits, vegetables, and nuts. Journal of Agricultural and Food Chemistry, 54 (26) 9966-9977. p.

HASLAM, E. (1989): Plant Polyphenols (1989). By E. Haslam. Chemistry and Pharmacology of Natural Products (J. D. Phillipson, D. C. Ayres and H. Baxter, Eds). Cambridge University Press: Cambridge, . BioEssays, 12 (9) 453-453. p. 10.1002/bies.950120912.

HEREDIA, F. J., FRANCIA-ARICHA, E. M., RIVAS-GONZALO, J. C., VICARIO, I. M. \& SANTOS-BUELGA, C. (1998): Chromatic characterization of anthocyanins from red grapes-I. pH effect. Food Chemistry, 63 (4) 491-498. p. http://dx.doi.org/10.1016/S03088146(98)00051-X. 
HERRMANN, K. (1976): Flavonols and flavones in food plants: a review $\dagger$. International Journal of Food Science \& Technology, 11 (5) 433-448. p. 10.1111/j.1365-2621.1976.tb00743.x.

HOLST, B. \& WILLIAMSON, G. (2008): Nutrients and phytochemicals: from bioavailability to bioefficacy beyond antioxidants. Current Opinion in Biotechnology, 19 (2) 73-82. p. 10.1016/j.copbio.2008.03.003.

HOSODA, K., FURUTA, T. \& ISHII, K. (2010): Simultaneous determination of glucuronic acid and sulfuric acid conjugated metabolites of daidzein and genistein in human plasma by high-performance liquid chromatography. Journal of Chromatography B-Analytical Technologies in the Biomedical and Life Sciences, 878 (7-8) 628-636. p. 10.1016/j.jchromb.2010.01.028.

HOSSAIN, M., BARRY-RYAN, C., MARTIN-DIANA, A. B. \& BRUNTON, N. (2010): Effect of drying method on the antioxidant capacity of six Lamiaceae herbs. Food Chemistry, 123 (1) 85-91.p.

HUANG, N., HAUCK, C., YUM, M.-Y., RIZSHSKY, L., WIDRLECHNER, M. P., MCCOY, J.A., MURPHY, P. A., DIXON, P. M., NIKOLAU, B. J. \& BIRT, D. F. (2009): Rosmarinic acid in Prunella vulgaris ethanol extract inhibits lipopolysaccharide-induced prostaglandin E2 and nitric oxide in RAW 264.7 mouse macrophages. Journal of Agricultural and Food Chemistry, 57 (22) 10579-10589. p.

HUDAIB, M., SPERONI, E., DI PIETRA, A. M. \& CAVRINI, V. (2002): GC/MS evaluation of thyme (Thymus vulgaris L.) oil composition and variations during the vegetative cycle. Journal of Pharmaceutical and Biomedical Analysis, 29 (4) 691-700. p.

HUGHES, R. J., CROLEY, T. R., METCALFE, C. D. \& MARCH, R. E. (2001): A tandem mass spectrometric study of selected characteristic flavonoids. International Journal of Mass Spectrometry, 210-211 371-385. p.

IETSWAART, J. H. \& IETSWAART, J. (1980): A taxonomic revision of the genus Origanum (Labiatae), Leiden University Press The Hague.

JACOB, R. A., SPINOZZI, G. M., SIMON, V. A., KELLEY, D. S., PRIOR, R. L., HESS-PIERCE, B. \& KADER, A. A. (2003): Consumption of cherries lowers plasma urate in healthy women. The Journal of nutrition, 133 (6) 1826-1829. p.

JUSTESEN, U., KNUTHSEN, P. \& LETH, T. (1998): Quantitative analysis of flavonols, flavones, and flavanones in fruits, vegetables and beverages by high-performance liquid chromatography with photo-diode array and mass spectrometric detection. Journal of Chromatography A, 799 (1-2) 101-110. p. 
KÄHKÖNEN, M. P., HEINÄMÄKI, J., OLLILAINEN, V. \& HEINONEN, M. (2003): Berry anthocyanins: isolation, identification and antioxidant activities. Journal of the Science of Food and Agriculture, 83 (14) 1403-1411. p. 10.1002/jsfa.1511.

KANG, S. Y., SEERAM, N. P., NAIR, M. G. \& BOURQUIN, L. D. (2003): Tart cherry anthocyanins inhibit tumor development in $\mathrm{Apc}(\mathrm{Min})$ mice and reduce proliferation of human colon cancer cells. Cancer Letters, 194 (1) 13-9. p.

KARKOUlA, E., SKANTZARI, A., MELliOU, E. \& MAGIATIS, P. (2014): Quantitative measurement of major secoiridoid derivatives in olive oil using qNMR. Proof of the artificial formation of aldehydic oleuropein and ligstroside aglycon isomers. Journal of Agricultural and Food Chemistry, 62 (3) 600-607. p. 10.1021/jf404421p.

KENNEDY, J. A. \& WATERHOUSE, A. L. (2000): Analysis of pigmented high-molecular-mass grape phenolics using ion-pair, normal-phase high-performance liquid chromatography. Journal of Chromatography A, 866 (1) 25-34. p. http://dx.doi.org/10.1016/S00219673(99)01038-9.

KING, H. G. C. (1962): Phenolic Compounds of Commercial Wheat Germ. Journal of Food Science, 27 (5) 446-454. p. 10.1111/j.1365-2621.1962.tb00125.x.

KINTZIOS, S. E. (2002): Profile of the multifaceted prince of the herbs.

KONCZAK, I. \& ZHANG, W. (2004): Anthocyanins-More Than Nature's Colours. J Biomed Biotechnol, 2004 (5) 239-240. p. 10.1155/s1110724304407013.

KONG, J.-M., CHIA, L.-S., GOH, N.-K., CHIA, T.-F. \& BROUILLARD, R. (2003): Analysis and biological activities of anthocyanins. Phytochemistry, 64 (5) 923-933. p. http://dx.doi.org/10.1016/S0031-9422(03)00438-2.

KRYGIER, K., SOSULSKI, F. \& HOGGE, L. (1982): Free, esterified, and insoluble-bound phenolic acids. 1. Extraction and purification procedure. Journal of Agricultural and Food Chemistry, 30 (2) 330-334. p.

KSH (2006): Mezögazdasági Statisztikai Évkönyv 2005, Budapest, Központi Statisztikai Hivatal.

KUHNAU, J. (1976): The flavonoids. A class of semi-essential food components: their role in human nutrition. World Review of Nutrition and Dietetics, 24 117-91.p.

LAKENBRINK, C., LAPCZYNSKI, S., MAIWALD, B. \& ENGELHARDT, U. H. (2000): Flavonoids and other polyphenols in consumer brews of tea and other caffeinated beverages. Journal of Agricultural and Food Chemistry, 48 (7) 2848-52. p.

LANDRAULT, N., LARRONDE, F., DELAUNAY, J. C., CASTAGNINO, C., VERCAUTEREN, J., MERILlON, J. M., GASC, F., CROS, G. \& TEISSEDRE, P. L. (2002): Levels of 
stilbene oligomers and astilbin in French varietal wines and in grapes during noble rot development. Journal of Agricultural Food Chemistry, 50 (7) 2046-52. p.

LARSON, A., SYMONS, J. D. \& JALILI, T. (2010): Quercetin: A Treatment for Hypertension?A Review of Efficacy and Mechanisms. Pharmaceuticals, 3 (1) 237-250. p.

LARSON, R. A. (1988): The antioxidants of higher plants. Phytochemistry, 27 (4) 969-978. p.

LEE, S.-J., UMANO, K., SHIBAMOTO, T. \& LEE, K.-G. (2005): Identification of volatile components in basil (Ocimum basilicum L.) and thyme leaves (Thymus vulgaris L.) and their antioxidant properties. Food Chemistry, 91 (1) 131-137. p.

LI, W., FRAME, L. T., HIRSCH, S. \& COBOS, E. (2010): Genistein and hematological malignancies. Cancer Letters, 296 (1) 1-8. p. 10.1016/j.canlet.2010.05.002.

LIGGINS, J., BLUCK, L., RUNSWICK, S., ATKINSON, C., COWARD, W. \& BINGHAM, S. (2000): Daidzein and genistein contents of vegetables. British Journal of Nutrition, 84 (5) 717-725. p.

LIN, L.-Z. \& HARNLY, J. M. (2007): A screening method for the identification of glycosylated flavonoids and other phenolic compounds using a standard analytical approach for all plant materials. Journal of Agricultural and Food Chemistry, 55 (4) 1084-1096. p.

LIN, L.-Z., MUKHOPADHYAY, S., ROBBINS, R. J. \& HARNLY, J. M. (2007): Identification and quantification of flavonoids of Mexican oregano (Lippia graveolens) by LC-DADESI/MS analysis. Journal of Food Composition and Analysis, 20 (5) 361-369. p. http://dx.doi.org/10.1016/j.jfca.2006.09.005.

MACHEIX, J.-J. \& FLEURIET, A. (1990): Fruit Phenolics.

MAILLARD, M.-N. \& BERSET, C. (1995): Evolution of antioxidant activity during kilning: role of insoluble bound phenolic acids of barley and malt. Journal of Agricultural and Food Chemistry, 43 (7) 1789-1793. p.

MANACH, C., SCALBERT, A., MORAND, C., RÉMÉSY, C. \& JIMÉNEZ, L. (2004): Polyphenols: food sources and bioavailability. The American Journal of Clinical Nutrition, 79 (5) 727-747. p.

MATTILA, P., ASTOLA, J. \& KUMPULAINEN, J. (2000): Determination of flavonoids in plant material by HPLC with diode-array and electro-array detections. Journal of Agricultural and Food Chemistry, 48 (12) 5834-5841.p.

MAZZA, G. M. E. (1993): Anthocyanins in fruits, vegetables, and grains, Boca Raton, CRC Press. MENENDEZ, J. A., VAZQUEZ-MARTIN, A., OLIVERAS-FERRAROS, C., GARCIAVILLALBA, R., CARRASCO-PANCORBO, A., FERNANDEZ-GUTIERREZ, A. \& SEGURA-CARRETERO, A. (2008): Analyzing effects of extra-virgin olive oil 
polyphenols on breast cancer-associated fatty acid synthase protein expression using reverse-phase protein microarrays. International journal of molecular medicine, 22 (4) 433-439. p.

MIURA, K. \& NAKATANI, N. (1989): Antioxidative activity of biphenyl compounds from thyme (Thymus vulgaris L.). Chemistry Letters, 4 237-239. p.

MONTEDORO, G., SERVIli, M., BAldioli, M., SElVAGGINI, R., MiNIATI, E. \& MACCHIONI, A. (1993): Simple and hydrolyzable compounds in virgin olive oil. 3. Spectroscopic characterizations of the secoiridoid derivatives. Journal of Agricultural and Food Chemistry, 41 (11) 2228-2234. p.

NACZK, M. \& SHAHIDI, F. (2004): Extraction and analysis of phenolics in food. Journal of Chromatography A, 1054 (1) 95-111. p.

NAEMURA, A., URA, M., YAMASHITA, T., ARAI, R. \& YAMAMOTO, J. (2008): Long-term intake of rosemary and common thyme herbs inhibits experimental thrombosis without prolongation of bleeding time. Thrombosis research, 122 (4) 517-522. p.

NYSTROM, C. W., WILLIAMS, B. L. \& WENDER, S. H. (1954): Enzymatic Hydrolysis Studies on Certain Flavonoid Glycosides. Journal of the American Chemical Society, 76 (7) 19501951.p.

OLIVEIRA, M., ESPERANCA, P. \& FERREIRA, A. (2001): Characterisation of anthocyanidins by electrospray ionisation and collision-induced dissociation tandem mass spectrometry. Rapid Communications in Mass Spectrometry, 15 (17) 1525-1532. p.

OLIVER, G. (1994): The American Spices Trade Association, a prime example of spice promotion. Remes Rencontres techniques et economiques plantes aromatiques et medicinales. Nyons, France: CFPPA, 220-223. p.

OMAR, S. H. (2010): Oleuropein in olive and its pharmacological effects. Scientia pharmaceutica, 78 (2) 133-154. p.

OWEN, R., GIACOSA, A., HULl, W., HAUBNER, R., SPIEGELHALDER, B. \& BARTSCH, H. (2000): The antioxidant/anticancer potential of phenolic compounds isolated from olive oil. European Journal of Cancer, 36 (10) 1235-1247. p.

PAIVA-MARTINS, F. T. \& PINTO, M. (2008): Isolation and characterization of a new hydroxytyrosol derivative from olive (Olea europaea) leaves. Journal of Agricultural Food Chemistry, 56 (14) 5582-5588. p.

PEREZ-JIMENEZ, F. (2005): International conference on the healthy effect of virgin olive oil. European Journal of Clinical Investigation, 35 (7) 421-424. p. 10.1111/j.13652362.2005.01516.x. 
PÉREZ-JIMÉNEZ， F., RUANO, J., PEREZ-MARTINEZ， P., LOPEZ-SEGURA， F. \& LOPEZ-MIRANDA, J. (2007): The influence of olive oil on human health: not a question of fat alone. Molecular nutrition \& food research, 51 (10) 1199-1208. p.

PÉREZ, J. A., HERNÁNDEZ, J. M., TRUJIllo, J. M. \& LÓPEZ, H. (2005): Iridoids and secoiridoids from Oleaceae. Studies in Natural Products Chemistry, 32 303-363. p.

PETER, K. (2004): Handbook of Herbs and Spices, Woodhead publishing.

PH.HG. (2004): 8. Magyar Gyógyszerkönyv, Pharmacopoea Hungarica, Medicina Press, Budapest.

PICCOLELlA, S., FIORENTINO, A., PACIFICO, S., D’ABROSCA, B., UZZO, P. \& MONACO, P. (2008): Antioxidant properties of sour cherries (Prunus cerasus L.): Role of colorless phytochemicals from the methanolic extract of ripe fruits. Journal of Agricultural and Food Chemistry, 56 (6) 1928-1935. p.

PIETTA, P.-G. (2000): Flavonoids as antioxidants. Journal of Natural Products, 63 (7) 10351042. p.

PIETTA, P. G. \& SIMONETTI, P. (1998): Dietary flavonoids and interaction with physiologic antioxidants. Antioxidant food supplements and human health. Academic Press San Diego.

PRASAIN, J. K., WANG, C.-C. \& BARNES, S. (2004): Mass spectrometric methods for the determination of flavonoids in biological samples. Free Radical Biology and Medicine, 37 (9) 1324-1350.p.

PRICE, S. F., BREEN, P. J., VALLADAO, M. \& WATSON, B. T. (1995): Cluster Sun Exposure and Quercetin in Pinot noir Grapes and Wine. American Journal of Enology and Viticulture, 46 (2) 187-194. p.

RAK, G., FODOR, P. \& ABRANKÓ, L. (2010): Three-step HPLC-ESI-MS/MS procedure for screening and identifying non-target flavonoid derivatives. International Journal of Mass Spectrometry, 290 (1) 32-38. p.

RAMIREZ-TORTOSA, M. C., GRANADOS, S., QUILES, J. L. \& YAQOOB, P. (2006): Chemical composition, types and characteristics of olive oil. Olive oil and health, 45-61. p.

REIN, M. (2005 ): Copigmentation reactions and color stability of berry anthocyanins Helsinki University of Helsinki Department of Applied Chemistry and Microbiology Food Chemistry Division

RENAUD, S. D. \& DE LORGERIL, M. (1992): Wine, alcohol, platelets, and the French paradox for coronary heart disease. The Lancet, 339 (8808) 1523-1526. p.

RIBÉREAU-GAYON, P. (1972): Plant Phenolics, Hafner Publishing Company.

RÍOS, J. J., GIL, M. J. \& GUTIÉRREZ-ROSALES, F. (2005): Solid-phase extraction gas chromatography-ion trap-mass spectrometry qualitative method for evaluation of phenolic 
compounds in virgin olive oil and structural confirmation of oleuropein and ligstroside aglycons and their oxidation products. Journal of Chromatography A, 1093 (1-2) 167-176. p. http://dx.doi.org/10.1016/j.chroma.2005.07.033.

ROBARDS, K. \& ANTOLOVICH, M. (1997): Analytical Chemistry of Fruit Bioflavonoids: A Review. Analyst, 122 (2) 11R-34R. p.

ROBBINS, R. J. (2003): Phenolic acids in foods: an overview of analytical methodology. Journal of Agricultural and Food Chemistry, 51 (10) 2866-2887. p.

RODRIGUEZ, S., MARSTON, A., WOLFENDER, J. \& HOSTETTMANN, K. (1998): Iridoids and secoiridoids in the Gentianaceae. Current Organic Chemistry, 2 627-648. p.

RYAN, D., ANTOlOVICH, M., HERLT, T., PRENZLER, P. D., LAVEE, S. \& ROBARDS, K. (2002): Identification of phenolic compounds in tissues of the novel olive cultivar hardy's mammoth. Journal of Agricultural and Food Chemistry, 50 (23) 6716-24. p.

RYAN, D. \& ROBARDS, K. (1998): Critical Review. Phenolic compounds in olives. Analyst, 123 (5) 31R-44R. p.

SANTOS-BUELGA, C. \& SCALBERT, A. (2000): Proanthocyanidins and tannin-like compounds - nature, occurrence, dietary intake and effects on nutrition and health. Journal of the Science of Food and Agriculture, 80 (7) 1094-1117. p. 10.1002/(SICI)10970010(20000515)80:7<1094::AID-JSFA569>3.0.CO;2-1.

SARTELET, H., SERGHAT, S., LOBSTEIN, A., INGENBLEEK, Y., ANTON, R., PETITFRERE, E., AGUIE-AGUIE, G., MARTINY, L. \& HAYE, B. (1996): Flavonoids extracted from fonio millet (Digitaria exilis) reveal potent antithyroid properties. Nutrition, 12 (2) 100-6. p.

SASS-KISS, A., KISS, J., MILOTAY, P., KEREK, M. \& TOTH-MARKUS, M. (2005): Differences in anthocyanin and carotenoid content of fruits and vegetables. Food Research International, 38 (8) 1023-1029. p.

SAVARESE, M., DE MARCO, E. \& SACCHI, R. (2007): Characterization of phenolic extracts from olives (Olea europaea cv. Pisciottana) by electrospray ionization mass spectrometry. Food Chemistry, 105 (2) 761-770. p. http://dx.doi.org/10.1016/j.foodchem.2007.01.037.

SCARMEAS, N., STERN, Y., TANG, M. X., MAYEUX, R. \& LUCHSINGER, J. A. (2006): Mediterranean diet and risk for Alzheimer's disease. Annals of neurology, 59 (6) 912-921. p.

SCHIJLEN, E. G., RIC DE VOS, C. H., VAN TUNEN, A. J. \& BOVY, A. G. (2004): Modification of flavonoid biosynthesis in crop plants. Phytochemistry, 65 (19) 2631-48. p. 10.1016/j.phytochem.2004.07.028. 
SERrANO, M., GUILlÉN, F., MARTÍNEZ-ROMERO, D., CASTILlO, S. \& VALERO, D. (2005): Chemical constituents and antioxidant activity of sweet cherry at different ripening stages. Journal of Agricultural and Food Chemistry, 53 (7) 2741-2745. p.

SERVILI, M. \& MONTEDORO, G. (2002): Contribution of phenolic compounds to virgin olive oil quality. European Journal of Lipid Science and Technology, 104 (9-10) 602-613. p.

SHAHIDI, F. \& NACZK, M. (2003): Phenolics in food and nutraceuticals, CRC press.

SHAHIDI F, N. M. (1995): Food phenolics, sources, chemistry, effects, applications., Technomic Publishing Co Inc.

SHEN, Y. C., CHEN, C. F., GAO, J., ZHAO, C. \& CHEN, C. Y. (2000): Secoiridoids glycosides from some selected Jasminum spp. Journal of the Chinese Chemical Society, 47 (2) 367372. p.

SHETTY, K. (1997): Biotechnology to harness the benefits of dietary phenolics; focus on Lamiaceae. Asia Pacific Journal of Clinical Nutrition, 6 162-171.p.

SHIRLEY, B. W. (1996): Flavonoid biosynthesis: 'new' functions for an 'old' pathway. Trends in Plant Science, 1 (11) 377-382. p. http://dx.doi.org/10.1016/S1360-1385(96)80312-8.

SILVA, S., GOMES, L., LEITÃO, F., BRONZE, M., COELHO, A. V. \& BOAS, L. V. (2010): Secoiridoids in olive seed: characterization of nüzhenide and 11-methyl oleosides by liquid chromatography with diode array and mass spectrometry. Grasas y aceites, 61 (2) 157-164. p.

SIMON, T. (2000): A magyarországi edényes flóra határozója, Budapest, Nemzeti Tankönyvkiadó Rt.366, 377

SLIMESTAD, R., FOSSEN, T. \& VAGEN, I. M. (2007): Onions: a source of unique dietary flavonoids. Journal of Agricultural and Food Chemistry, 55 (25) 10067-80. p. $10.1021 / \mathrm{jf0712503.}$

STAFFORD, H. A. (1988): Proanthocyanidins and the lignin connection. Phytochemistry, 27 (1) 1-6. p. http://dx.doi.org/10.1016/0031-9422(88)80583-1.

STRACK, D. (1997): Phenolic metabolism, Academic Press, London.387-416.

SUÁREZ, M., MACIÀ, A., ROMERO, M.-P. \& MOTILVA, M.-J. (2008): Improved liquid chromatography tandem mass spectrometry method for the determination of phenolic compounds in virgin olive oil. Journal of Chromatography A, 1214 (1-2) 90-99. p. http://dx.doi.org/10.1016/j.chroma.2008.10.098.

SUÁREZ, M., ROMERO, M.-P., RAMO, T. S., MACIÀ, A. \& MOTILVA, M.-J. (2009): Methods for preparing phenolic extracts from olive cake for potential application as food 
antioxidants. Journal of Agricultural and Food Chemistry, 57 (4) 1463-1472. p. $10.1021 / \mathrm{j} f 8032254$.

TALL, J. M., SEERAM, N. P., ZHAO, C., NAIR, M. G., MEYER, R. A. \& RAJA, S. N. (2004): Tart cherry anthocyanins suppress inflammation-induced pain behavior in rat. Behavioural brain research, 153 (1) 181-188. p.

TIMBERLAKE, C. F. \& BRIDLE, P. (1976): Interactions between anthocyanins, phenolic compounds, and acetaldehyde and their significance in red wines. American Journal of Enology and Viticulture, 27 (3) 97-105. p.

TOKUŞOĞLU, Ö. \& HALL III, C. A. (2011): Fruit and Cereal Bioactives: Sources, Chemistry, and Applications, CRC Press.

TOMÁS-BARBERÁN, F. A. \& CLIFFORD, M. N. (2000): Flavanones, chalcones and dihydrochalcones - nature, occurrence and dietary burden. Journal of the Science of Food and Agriculture, $\quad 80 \quad$ (7) $\quad 1073-1080 . \quad$ p. $10.1002 /($ SICI) $1097-$ 0010(20000515)80:7<1073::AID-JSFA568>3.0.CO;2-B.

TRICHOPOUlOU, A., COSTACOU, T., BAMIA, C. \& TRICHOPOULOS, D. (2003): Adherence to a Mediterranean diet and survival in a Greek population. New England Journal of Medicine, 348 (26) 2599-2608. p.

TRUCHADO, P., FERRERES, F. \& TOMAS-BARBERAN, F. A. (2009): Liquid chromatography-tandem mass spectrometry reveals the widespread occurrence of flavonoid glycosides in honey, and their potential as floral origin markers. Journal of Chromatography A, 1216 (43) 7241-7248. p.

TUCKER, A. O. \& DEBAGGIO, T. (2000): The big book of herbs: a comprehensive illustrated reference to herbs of flavor and fragrance, Interweave Pr.

TUCKER, A. O. \& MACIARELLO, M. J. (1994): Oregano: botany, chemistry, and cultivation. Amsterdam: Elsevier Science BV.

TULIO, A. Z., JR., REESE, R. N., WYZGOSKI, F. J., RINALDI, P. L., FU, R., SCHEERENS, J. C. \& MILlER, A. R. (2008): Cyanidin 3-rutinoside and cyanidin 3-xylosylrutinoside as primary phenolic antioxidants in black raspberry. Journal of Agricultural and Food Chemistry, 56 (6) 1880-8. p. 10.1021/jf072313k.

VEBERIC, R. \& STAMPAR, F. (2005): Selected polyphenols in fruits of different cultivars of genus Prunus. Phyton, 45 (3) 375-383. p.

VILA, R. (2002): Flavonoids and further polyphenols in the genus Thymus, Taylor \& Francis: New York. 
VINHA, A. F., FERRERES, F., SILVA, B. M., VALENTAO, P., GONÇALVES, A., PEREIRA, J. A., OLIVEIRA, M. B., SEABRA, R. M. \& ANDRADE, P. B. (2005): Phenolic profiles of Portuguese olive fruits (Olea europaea L.): Influences of cultivar and geographical origin. Food Chemistry, 89 (4) 561-568. p.

VITRAC, X., MONTI, J.-P., VERCAUTEREN, J., DEFFIEUX, G. \& MÉRILLON, J.-M. (2002): Direct liquid chromatographic analysis of resveratrol derivatives and flavanonols in wines with absorbance and fluorescence detection. Analytica Chimica Acta, 458 (1) 103-110. p. http://dx.doi.org/10.1016/S0003-2670(01)01498-2.

VLAHOV, G., GIULIANI, A. A. \& DEL RE, P. (2010): 13C NMR spectroscopy for determining the acylglycerol positional composition of lampante olive oils. Chemical shift assignments and their dependence on sample concentration. Analytical Methods, 2 (7) 916-923. p.

VON ELBE, J. \& SCHWARTZ, S. (1996): Colorants. Food Chemistry, 3 651-723. p.

VUKICS, V. \& GUTTMAN, A. (2010): Structural characterization of flavonoid glycosides by multi-stage mass spectrometry. Mass Spectrometry Reviews, 29 (1) 1-16. p.

WANG, H., NAIR, M. G., IEZZONI, A. F., STRASBURG, G. M., BOOREN, A. M. \& GRAY, J. I. (1997): Quantification and characterization of anthocyanins in balaton tart cherries. Journal of Agricultural and Food Chemistry, 45 (7) 2556-2560. p. 10.1021/jf960896k.

WOLFENDER, J.-L., VIOLETTE, A. \& FAY, L. B. (2010): Chapter 6 Mass Spectrometry in Phytonutrient Research. Mass Spectrometry and Nutrition Research. The Royal Society of Chemistry. 10.1039/9781849730921-00163

WROLSTAD, R. E., DURST, R. W. \& LEE, J. (2005): Tracking color and pigment changes in anthocyanin products. Trends in Food Science \& Technology, 16 (9) 423-428. p. http://dx.doi.org/10.1016/j.tifs.2005.03.019.

XAVIER, C. P., LIMA, C. F., FERNANDES-FERREIRA, M. \& PEREIRA-WILSON, C. (2009): Salvia fruticosa, Salvia officinalis, and rosmarinic acid induce apoptosis and inhibit proliferation of human colorectal cell lines: the role in MAPK/ERK pathway. Nutrition and cancer, 61 (4) 564-571. p.

YAMAMOTO, J., YAMADA, K., NAEMURA, A., YAMASHITA, T. \& ARAI, R. (2005): Testing various herbs for antithrombotic effect. Nutrition, 21 (5) 580-7. p. 10.1016/j.nut.2004.09.016.

YAMASAKI, H., SAKIHAMA, Y. \& IKEHARA, N. (1997): Flavonoid-Peroxidase Reaction as a Detoxification Mechanism of Plant Cells against H2O2. Plant Physiol, 115 (4) 1405-1412. p. 
ZABOROWSKA, Z., PRZYGOŃSKI, K. \& BILSKA, A. (2012): Antioxidative effect of thyme (Thymus vulgaris) in sunflower oil. Acta Sci. Pol., Technol. Aliment, 11 (3) 283-291. p.

ŽIAKOVÁ, A., BRANDŠTETEROVÁ, E. \& BLAHOVÁ, E. (2003): Matrix solid-phase dispersion for the liquid chromatographic determination of phenolic acids in Melissa officinalis. Journal of Chromatography A, $983 \quad(1-2) \quad 271-275 . \quad$ p. http://dx.doi.org/10.1016/S0021-9673(02)01712-0. 


\section{MELLÉKLETEK}

Melléklet 1: Az 5.3. fejezetben vizsgált aglikonok termékion spektrumjai, jelölve a kiválasztott fragmentumokat
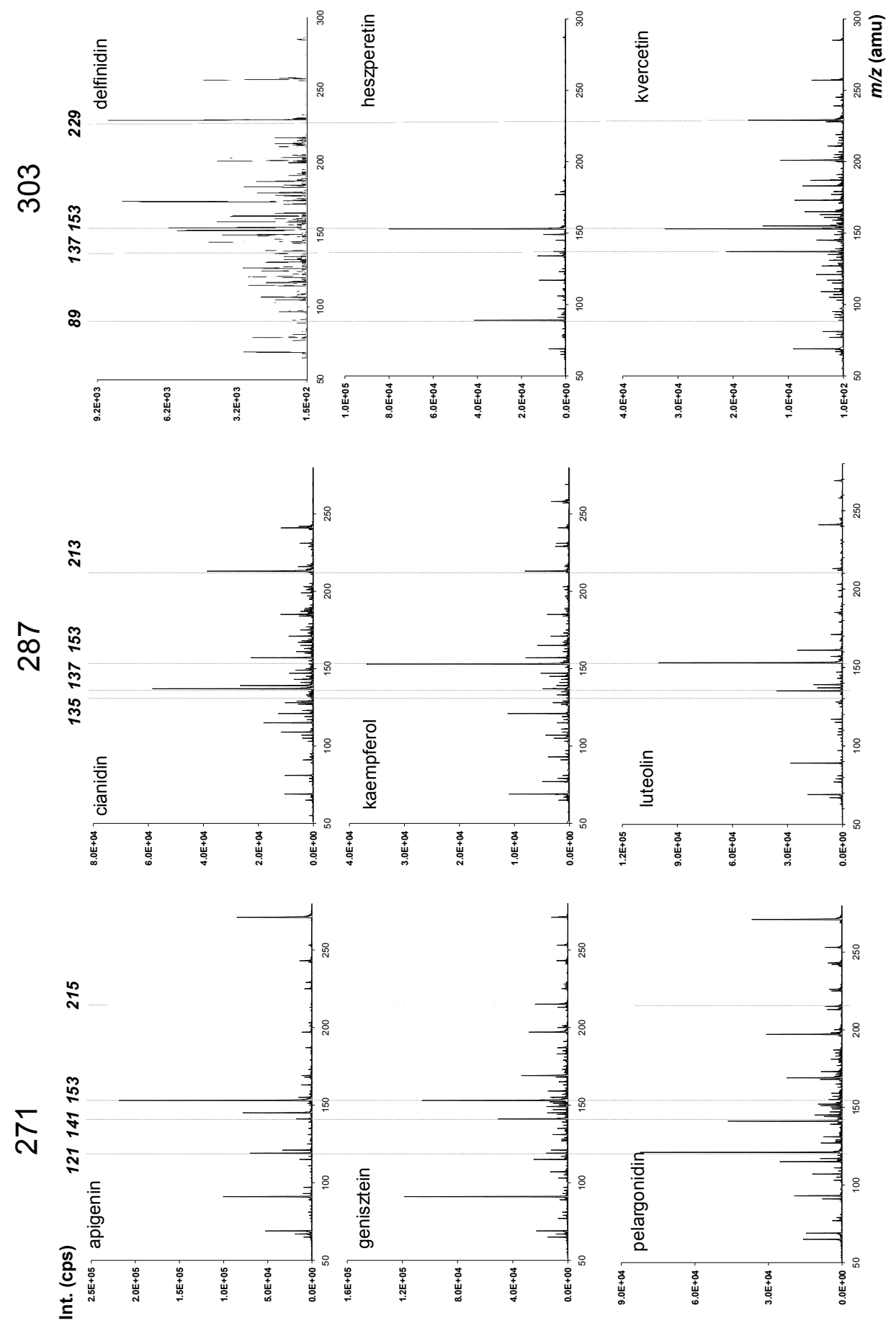
Melléklet 2: Kakukk és szurokfüvekből két fajta minta-előkészítés (vizes hígítás és lúgos hidrolízis) segítségével mért fenolos savak eredményei

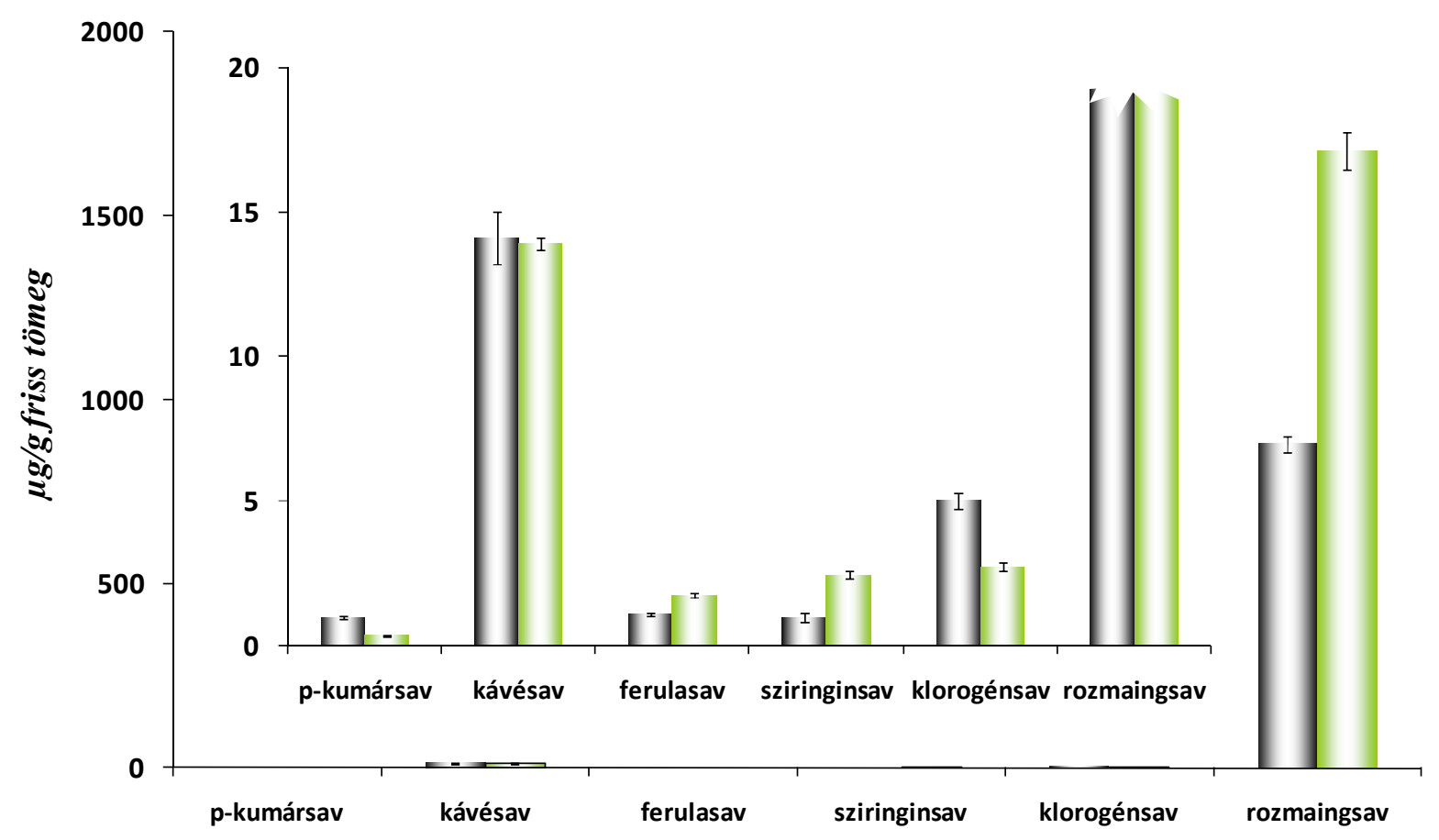

Timolos (zöld színü oszlopok) és nem timolos (szürke szinü oszlopok)kakukkfüvek fenolos savainak mennyisége a vizes extraktumban

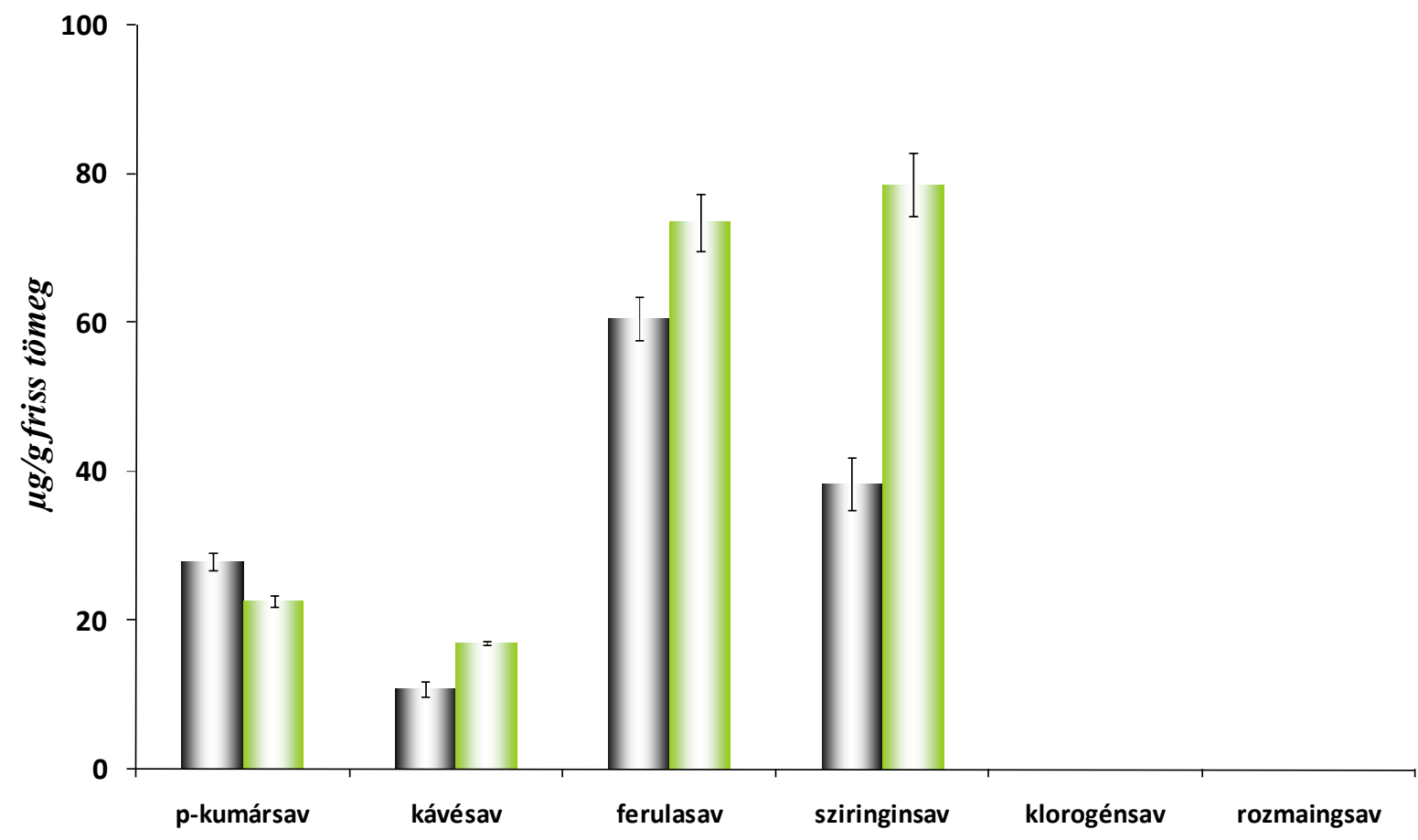

Timolos és nem timolos kakukkfüvek fenolos savainak mennyisége a vizes extraktumban, lúgos hidrolízist követöen 


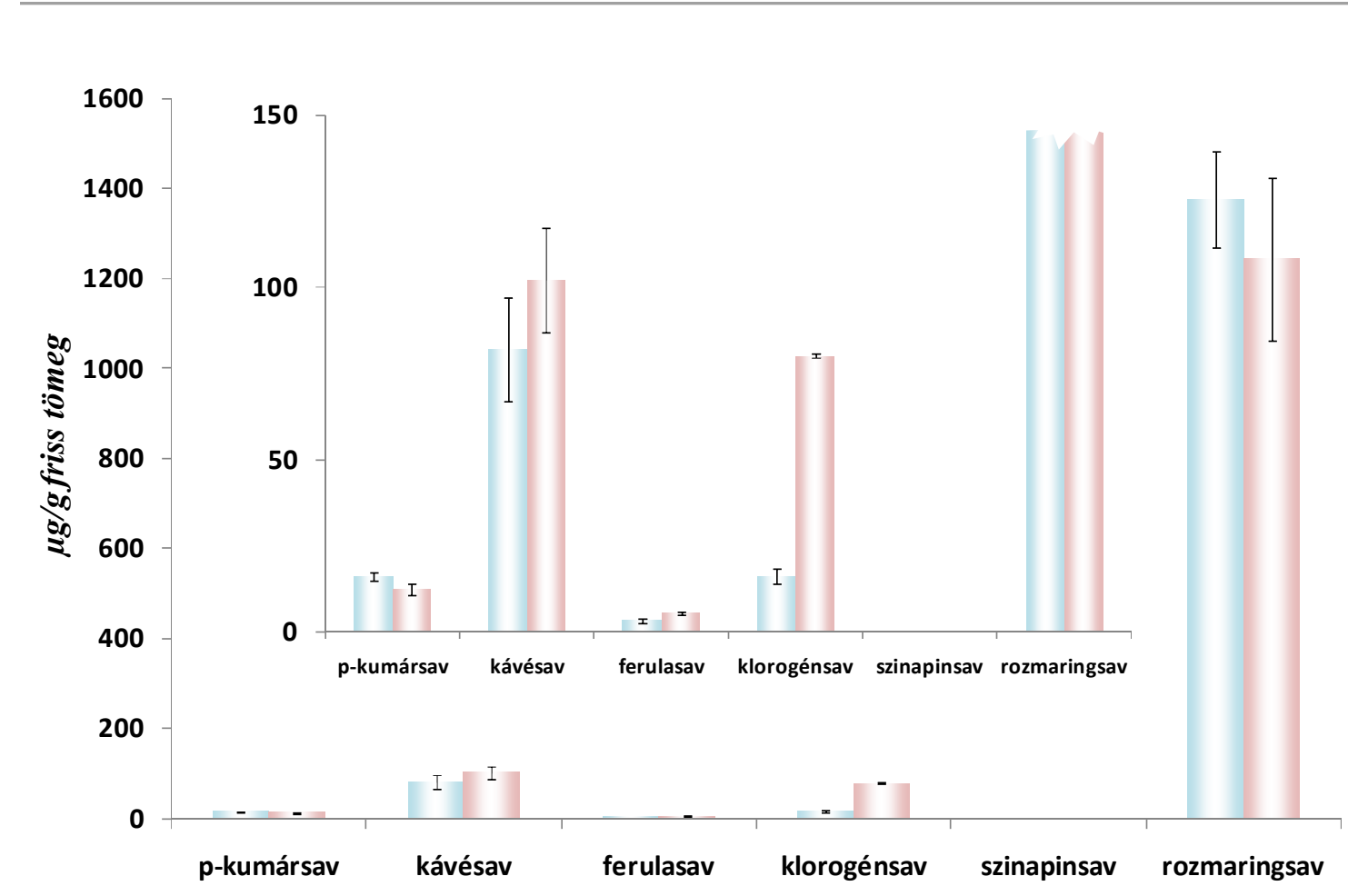

Görög (mályva színü oszlopok)- és közönséges (kék színü oszlopok) szurokfüvek fenolos savainak mennyisége a vizes extraktumban

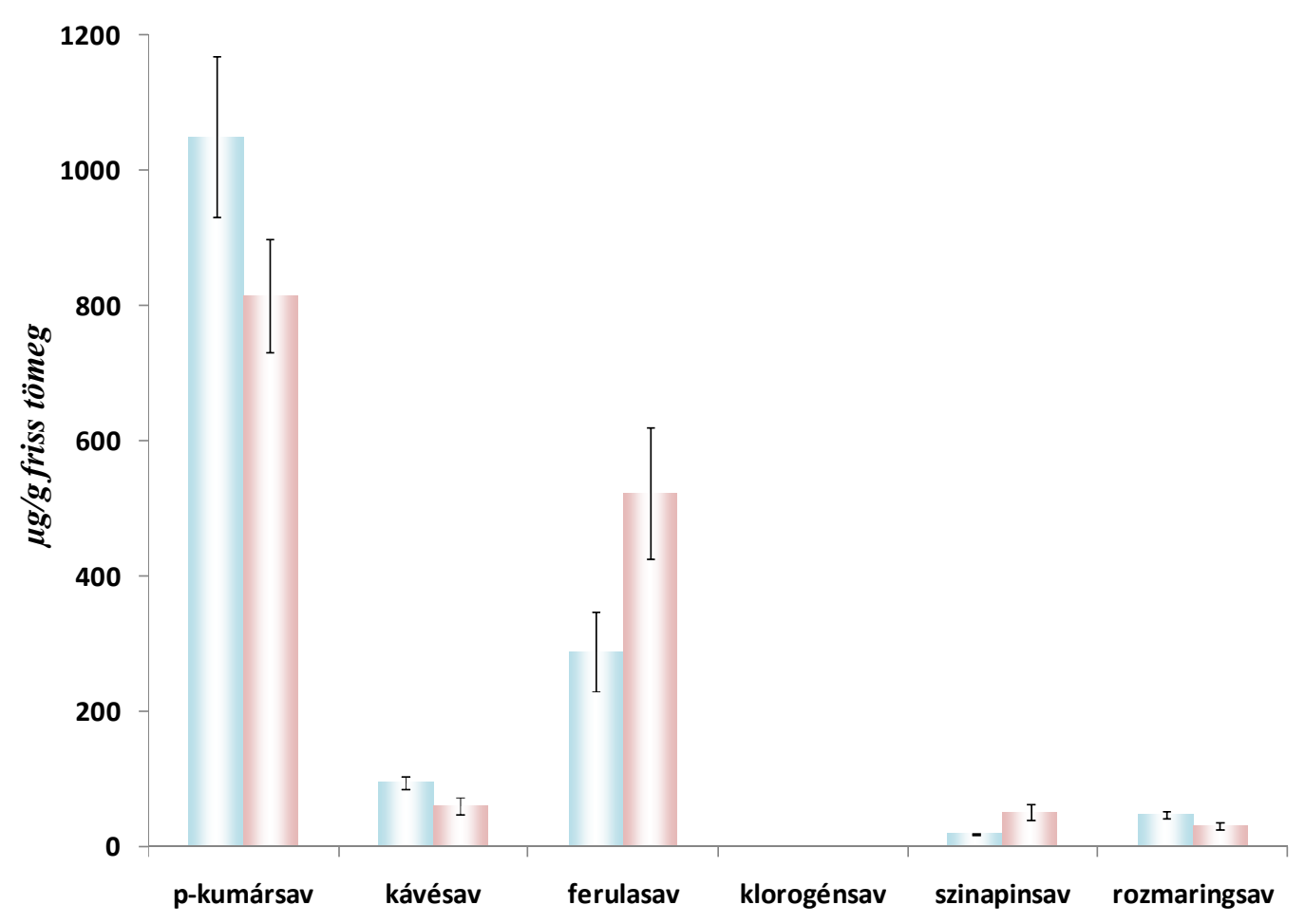

Görög (mályva szinü oszlopok)- és közönséges (kék színü oszlopok) szurokfüvek fenolos savainak mennyisége a vizes extraktumban, lúgos hidrolizist követöen 


\section{KÖSZÖNETNYILVÁNÍTÁS}

Szeretnék köszönetet mondani mindazoknak, akik segítségemre voltak doktori munkám során.

Elsőként köszönöm témavezetőmnek, Dr. Abrankó Lászlónak, az éveken át, egészen e dolgozat megszületéséig tartó útmutatást, fáradhatatlan segítségnyújtást, bíztatást, odafigyelést, amiből mindig erőt és tudást meríthettem.

Szeretném megköszönni családomnak, hogy mindig mellettem álltak, bátorítottak. Különösen köszönöm Édesanyámnak, Szilvássyné Mertz Klárának szakadatlan támogatását, energiáját, és hogy vegyészmérnöki hozzáállásával, számos alkalommal segítette munkámat.

Szeretnék köszönetet mondani Stefanovitsné Dr. Bányai Évának, az Alkalmazott Kémia Tanszék vezetőjének, akinek segítségével megismerhettem a tanszék és a kutatómunka világát.

Továbbá köszönettel tartozom, Dr. Fodor Péternek, aki kísérleti munkáim során tanszékvezetőként, biztosította a sikeres vizsgálatokhoz szükséges emberi, szakmai és müszeres hátteret.

Köszönöm Dr. Tavaszi-Sárosi Szilviának és Dr. Novák Ildikónak, illetve a Gyógy- és Aromanövények Tanszék további dolgozóinak az együttmüködést a gyógynövények vizsgálatában.

Továbbá köszönettel tartozom a Jaén-i Egyetem Analitikai Tanszékén dolgozó munkatársaknak, köztük Juan Francisco Garcia Reyes-nek, hogy segítettek három hónapos spanyolországi utam alkalmával a kísérletek kivitelezésében.

Köszönöm, Dr. Sárdi Éva és Dr. Bartók Tibor opponensi munkáját házi védésem során.

Ezen kívül köszönöm doktorandusz társaimnak és a tanszék dolgozóinak tanácsaikat, segítségüket és az együtt töltött idöt.

Köszönet az anyagi támogatásért a következőknek: Magyar Állami Doktori Ösztöndíj, Erasmus Ösztöndíj, Corvinus Visiting Scholar Programme-TÁMOP-4.2.1/B-09/1/KMR-2010-0005 